

\section{STUDIA UNIVERSITATIS HEREDITATI}

Znanstvena revija za raziskave in teorijo kulturne dediščine

Letnik 5 , številka 2, 2017

Studia universitatis hereditati je humanistična znanstvena revija za raziskave in teorijo kulturne dediščine z mednarodnim uredniškim odborom. Objavlja znanstvene in strokovne članke s širšega področja kulturne dediščine (arheologija, arhitektura, etnologija, jezikoslovje, literarna, kulturna, glasbena, intelektualna, religijska, vojaška zgodovina, zgodovina idej itn.) in pregledne članke ter recenzije tako domačih kot tujih monografij z omenjenih področij. Revija izhaja dvakrat letno. Izdajata jo Fakulteta za bumanistične studije (Oddelek za arheologijo in dediscino) in Založba Univerze na Primorskem.

Poglavitni namen revije je prispevati k razvoju raziskav kulturne dediščine v najširšem in k topoglednemu interdisciplinarnemu pristopu $\mathrm{k}$ teoretičnim in praktičnim raziskovalnim vprašanjem. Tako revija posebno pozornost namenja razvoju slovenske znanstvene in strokovne terminologije, konceptov in paradigem na področju raziskovanja kulturne dediščine v okviru humanističnih ved.

\section{Glauni in odgovorni urednik}

dr. Gregor Pobežin (Fakulteta za humanistične študije Univerze na Primorskem, Koper)

Urednici stevilke

dr. Zrinka Mileusnić in dr. Alenka Tomaž (Fakulteta za humanistične študije Univerze na Primorskem, Koper) Tehnična ureditev revije, oblikovanje in prelom

dr. Jonatan Vinkler (Fakulteta za humanistične študije Univerze na Primorskem, Koper)

Lektor (slovenska besedila)

Davorin Dukič (Univerza na Primorskem, Koper)

\section{Uredniski odbor}

dr. Zdravka Hincak (Filozofski fakultet, Sveučilište u Zagrebu), dr. Matej Hriberšek (Filozofska fakulteta, Univerza v Ljubljani), dr. Katja Hrobat Virloget (Fakulteta za humanistične študije Univerze na Primorskem, Koper), dr. Irena Lazar (Fakulteta za humanistične študije Univerze na Primorskem, Koper), dr. Maša Sakara Sučevič (Pokrajinski muzej, Koper), dr. Alenka Tomaž (Fakulteta za humanistične študije Univerze na Primorskem, Koper), dr. Tomislav Vignjevič (Fakulteta za humanistične študije Univerze na Primorskem, Koper), dr. Jonatan Vinkler (Fakulteta za humanistične študije Univerze na Primorskem, Koper), dr. Paola Visentini (Museo Friulano di Storia Naturale, Udine)

Izdajatelj: Univerza na Primorskem - Založba Univerze na Primorskem (za Fakulteto za humanistične študije Univerze na Primorskem)

(C) 2017 Založba Univerze na Primorskem

Zanjo: prof. dr. Dragan Marušič, rektor

Titov $\operatorname{trg} 4$

SI-6000 Koper

ISSN $2350-5443$

DOI: https://doi.org/10.26493/2350-5443.5(2)

\section{(c) (i) $\circledast$}


studia universitatis hereditati 



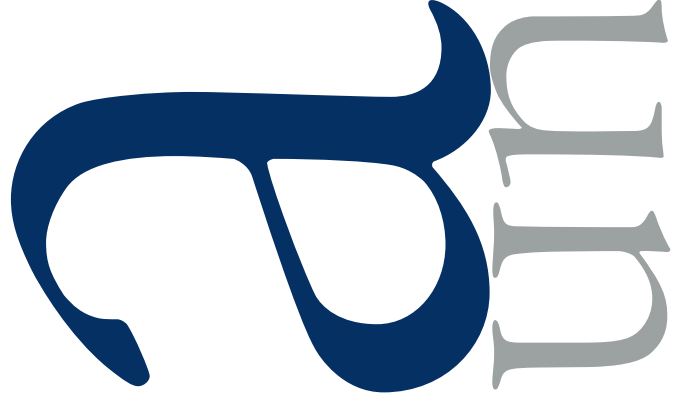

○
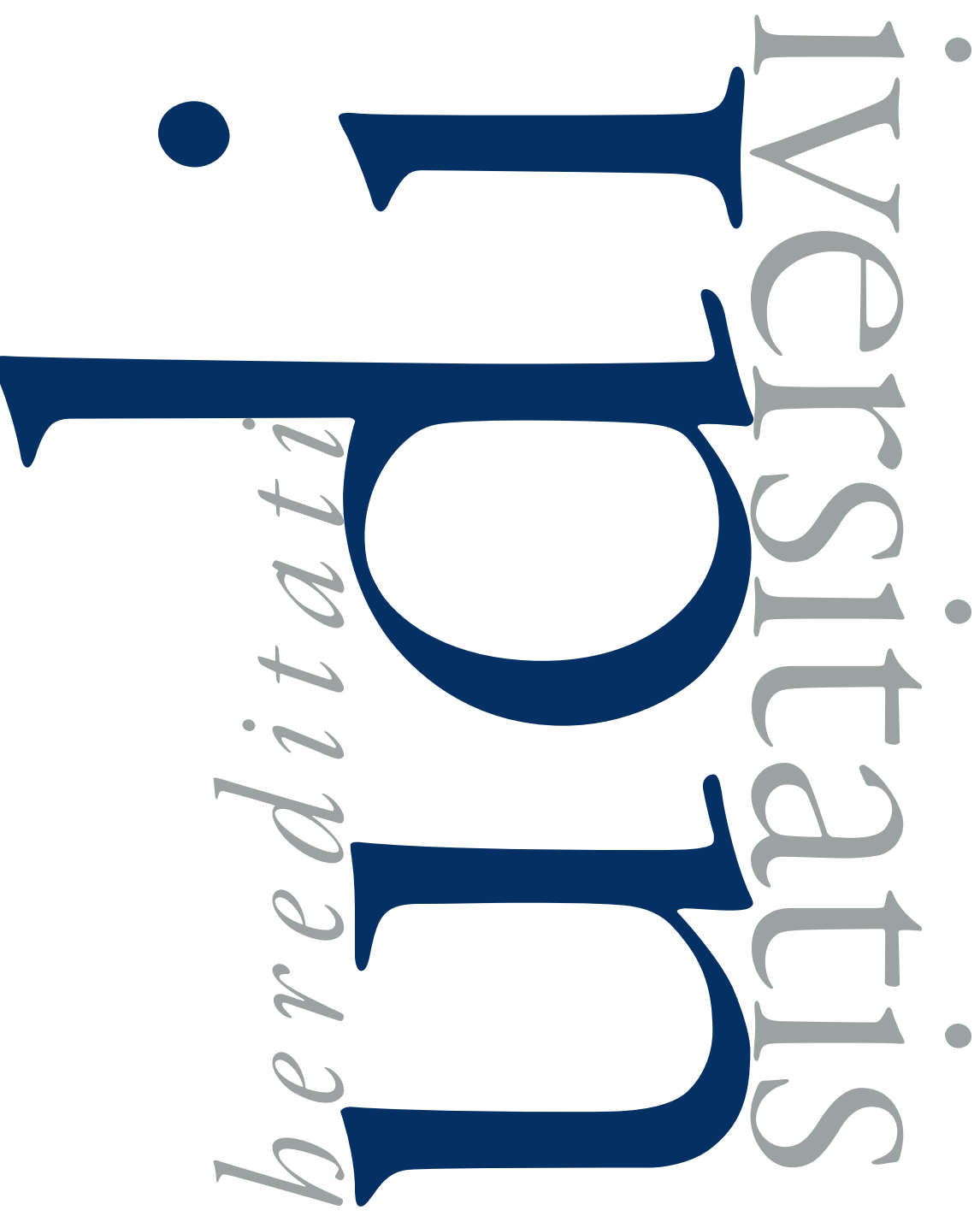

LETNIK 5

ŠTEVILKA 2

LETO 2017
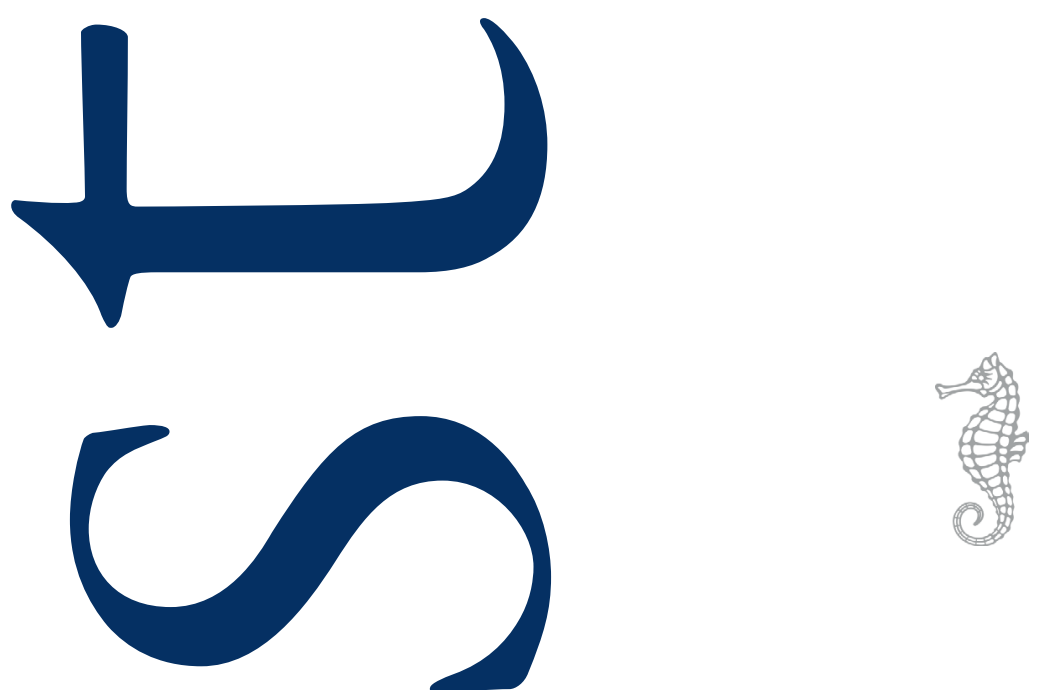
-

r

$\downarrow$

G

1

-

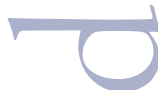

( )

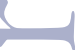

(U)

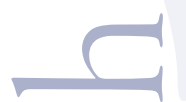




\section{Vsebina/Contents}

Julijana Visocnik, Bernarda Zupanek, Simona Jarc in Luka Gale

9 Rimski fragmenti z napisi v Mestnem muzeju Ljubljana

Jadranka Cergol

2 I I cambiamenti etnici sulla penisola Italica dalla guerra sociale alla morte dell'imperatore Augusto

Miba Mlinar

37 Rimski grob z zrcalcem z Lipičarjevega vrta na Mostu na Soči

Zdravka Hincak in Kresimir Filipec

47 Forensics and Archaeology: The Ethical Approach to Graves Excavation and Research Zorana Dimković

59 Nevidljiva dugovečnost u arheološkom kontekstu

Alenka Tomazin Maśa Sakara Sućevic

7I Arheološke raziskave na lokaciji Kaštelir nad Kortamiv letu 2014

Nenad Joncić

IOI Implementation of 3 D Scanning in Presentationand Preservation of Cultural Heritage Case Study: Dungeons of the National Museum in Pančevo 
-

r

$\downarrow$

G

1

-

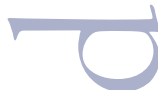

( )

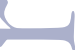

(U)

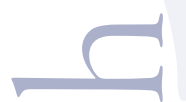




\title{
Rimski fragmenti z napisi v Mestnem muzeju Ljubljana
}

\author{
1 Julijana Visočnik, Nadškofijski arhiv Ljubljana \\ Bernarda Županek, Muzej in galerije mesta Ljubljana \\ Simona Jarc, Univerza v Ljubljani, Naravoslovnotehniška fakulteta, \\ Oddelek za geologijo \\ Luka Gale, Univerza v Ljubljani, Naravoslovnotehniška fakulteta, \\ Oddelek za geologijo in Geološki zavod Slovenije
}

Prispevek predstavlja epigrafsko analizo napisov, ki so ohranjeni na enajstih še neobjavljenih odlomkih spomenikov z območja rimske Emone, hranjenih v Mestnem muzeju Ljubljana. Vsi so bili najverjetneje odkriti v sekundarni legi in izvirajo iz obdobja od I. do 3. stol. n. št.

Ključne besede: epigrafika, Emona, fragmenti, Mestni muzej Ljubljana, antika, geologija

Eleven inscriptions, discovered on as yet unpublished fragments of monuments from the territory of Roman Emona, are discussed in this contribution. The monuments, kept in the City Museum of Ljubljana, were most probably discovered in the secondary position and date from the ist to the $3 \mathrm{rd}$ century $\mathrm{AD}$.

Keywords: epigraphics, Emona, fragments, City museum of Ljubljana, Roman period, geology

$\mathrm{R}$ imski spomeniki z napisi so dragocen zgodovinski vir, vedno bolj pa jih dojemamo tudi kot našo kulturno dediščino. $\mathrm{V}$ nasprotju z njimi so majhni, fragmentarno ohranjeni odlomki za širšo javnost običajno manj zanimivi, zato se nemalokrat zgodi, da se ponovno izgubijo ali založijo. Tako je ključnega pomena, da se jih po odkritju čim prej objavi in tako prepreči, da bi ponovno utonili v pozabo. Avtorji tega prispevka smo se tako odločili, da zberemo še neobjavljene fragmente $\mathrm{z}$ napisi, ki jih $\mathrm{v}$ depoju hrani Mestni muzej Ljubljana. Prispevek tako predstavlja ıo do sedaj še neobjavljenih fragmentov in enega, ki je bil na kratko omenjen v Varstvu spomenikov 13-14. Odlomki z napisi so obravnavani $z$ arheološkega, epigrafskega in geološkega vidika. Poleg splošnega opisa kamnin, iz katerih so bili izdelani artefakti, podajamo tudi podroben litološki opis na podlagi mikroskopskih preparatov, kar je relativna novost $\mathrm{v}$ našem prostoru."

\section{Katalog obravnavanih spomenikov}

Fragment nagrobnega (?) spomenika

Najdišče: Ljubljana (Emona). Fragment so našli leta 1962 med arheološkimi raziskavami na Trgu revolucije v Ljubljani. Hranjen je v depoju Mestnega muzeja Ljubljana, inv. št. 5ıo:LJU;0048569.

Material: Svetlo siv apnenec s posamičnimi večjimi drobci školjk v zrnsko-podprti osnovi. Med drobnimi fosili so prepoznavne fosilne luknjičarke iz naddružine Orbitolinoidea. Slednje so znane iz kamnin spodnjekredne do oligocenske starosti ${ }^{1}$. Kamnina je domnevno kredne starosti. Izvor ni poznan.

Mere: 14 X Is X 5,6 cm, velikost črk: 5 (v. I), 4,4 (v. 2) cm.

Opis: Odlomek napisnega kamna iz sivega apnenca. Na njegovi površini so vidni ostanki malte, verjetno je bil kam vzidan. Ohranjen je desni zgornji vogal napisne plošče, njena leva

\footnotetext{
(po Boudagher-Fadel, 2008)
} 
stran je obdana z malto. Črke so bile lepo klesane in so pravilnih oblik.

Neobjavljen.

$$
\left[\begin{array}{l}
{[--]+V T I A} \\
{[--]++C A}
\end{array}\right.
$$

\section{Prevod:}

V. ı: Zadnji dve črki v vrstici ı sta manjši: $\mathrm{I}=$ 4, $A=4.4 \mathrm{~cm}$. Po čiščenju kamna se je pred črko $\mathrm{V}$ pokazal ostanek še ene črke.

V. 2: Od prvih dveh črk sta ohranjena samo njuna zgornja dela. Prva je tako lahko I, L (črka s pokončno hasto), druga $\mathrm{C}$ ali morda $\mathrm{G}$.

Komentar: Glede na ostanke črk v prvi in drugi vrstici lahko trdimo, da sta bili na spomeniku zapisani dve ženski imeni. Ohranjenih črk je premalo, da bi lahko naredili verjeten izbor imen. Prav tako ne moremo zaključiti, če gre za ime tipa tria (duo) nomina ali dejansko za dve enodelni imeni.

Datacija: 1.-3. st.

\section{Fragment nagrobnega napisa za Januarijo}

Najdišče: Ljubljana (Emona). Fragment so našli med arheološkimi raziskavami na območju načrtovane nove Narodne in univerzitetne knjižnice (NUK II) leta 1990 v ruševinski plasti. Danes je hranjen v depoju Mestnega muzeja Ljubljana, inv. št. 510:LJU;0060I80.

Material: Gost temno siv apnenec brez večjih zrn ali z veliko količino drobnih belih zrn. Vsebuje lečasta nakopičenja 0,5 -I $\mathrm{cm}$ velikih belih školjčnih lupin. Mikrofosili (luknjičarke in problematični fosil Thaumatoporella) ustrezajo spodnjejurskim združbam. Kot možen izvor apnenca te starosti se najpogosteje omenja Podpeč

Mere: 30 × 22 x I8,5 cm, višina črk: 3,5 (v. I), 3 (v. 2$) \mathrm{cm}$.

Anton Ramovš, Podpeški in črni ter pisani lesnobrdski apnenec skozi čas (Ljubljana: Mineral, 2000); Bojan Djurić in Igor Rižnar, "Kamen Emone,"VEMONA MM, Urbanizacija prostora - nastanek mesta, ur. Bernarda Županek (Ljubljana: ZVKDS, MGML, 2017), $121-143$
Opis: Nagrobnik, ki je zelo verjetno imel obliko cippus (glede na debelino in polkrožno zaključen zgornji del). Spodnji del je odbit. Črke so lepo in pravilno klesane.

Neobjavljen.

\section{Ianuaria \\ ann (orum) $X V$ \\ -..--.?}

Prevod: Januarija, stara is let, ...

V. I.: Druga črka I je pomanjšana in meri 2 $\mathrm{cm}$.

Komentar: Ianuarius/-a je pogosto osebno ime, ki se pojavlja tudi kot družinsko ime. Razširjeno je predvsem na območjih s keltskim prebivalstvom, kar se lahko razloži z vplivom keltskih imen na Iantu- ${ }^{3}$ (iantu-: namere, načrti). Kajanto pa ga opredeli kot ime povezano s koledarjem (mesec) ${ }^{4}$.

Datacija: 2./3. st.

Mejnik grobne parcele (?)

Najdišče: Ljubljana (Emona). Najdiščnih podatkov ni. Hranjen je v depoju Mestnega muzeja Ljubljana, inv. št. 5ıo:LJU;0060203.

Material: Svetlo siv apnenec z gosto nakopičenimi drobnimi zrni. Mikrofosili, predvsem luknjičarki Orbitopsella sp. in Everticyclammina praevirguliana, kažejo na srednje spodnjejursko starost. Možen izvor tovrstne kamnine je območje Podpečí.

Mere: 53 x 29 x I $4,5 \mathrm{~cm}$, višina črk: $4 \mathrm{~cm}$.

Opis: Ohranjen je osrednji del kamna, ki je odbit z vseh strani. Ločilna znamenja so bila najverjetneje uporabljena, a jih zdaj več ni mogoče potrditi. V prvi vrstici so črke ohranjene bolj v obrisih.

Neobjavljen.

\footnotetext{
3 Primer OPEL II, 189-190; Fritz Lochner von Hüttenbach, Die römerzeitlichen Personennamen der Steiermark: Herkunft und Auswertung (Graz, 1989), 84; Wolfgang Meid, Keltische Personennamen in Pannonien (Budapest: Archaeolingua, 2005), 74-75, 109.

4 Primer Iiro Kajanto, The Latin Cognomina (Helsinki: Societas Scientiarum Fennica. Commentationes Humanarum Litterarum, XXXVI 2, 1965), 218.

5 Ramovš, Podpeški in črni ter pisani lesnobrdski apnenec skozi čas; Djurić in Rižnar, "Kamen Emone," I2 I-1 43
} 
$+++$

In $\mathrm{f}$ (ronte) $\mathrm{p}$ (edes) $\mathrm{LX}$

In ag(ro) $\mathrm{p}$ (edes) XX-

II -.--- ?

Prevod: ... v širino 60, v dolžino 22 (?) čevljev ...

V. I: Na začetku besedila bi pričakovali besedno zvezo Locus monumenti, najeverjetneje v obliki L M, zdi pa se, da so ohranjeni ostanki štirih črk (morda L V P I). V tem primeru bi morda lahko šlo tudi za daljšo formulo: L M Q V P ..., torej locus monumenti quoque versus pedes ... Na spomeniku bi tako kar na dva načina povedali oz. poudarili velikost grobne parcele, ki bi bila po dolžini in po širini 20 čevljev.

V. 2:. Pred prvo črko pa je morda samo posledica klesarjeve napake. $\mathrm{F}$ in $\mathrm{R} v$ frontes sta najverjetneje v ligaturi.

Komentar: Merska enota rimski čevelj (pedes) je meril ca. I/3 metra, torej 5 čevljev je tvorilo I korak (passus). Velikost grobnih parcel v Emoni je bila povprečna, če jih primerjamo npr. $\mathrm{s}$ tistimi iz Akvileje, prim. komentar k RINMS 69 in 70 . Glej še podobne spomenike ILJug I09I, ILJug 1092, ILJug 1093 in ILJug 1094, kjer se velikost grobnih parcel giba med 20 in 30 čevlji.

Datacija: Najverjetneje I. stoletje.

\section{Fragment mejnika grobne parcele}

Najdišče: Ljubljana (Emona). Fragment so našli leta 1972 med obnovo kanalizacije pri ljubljanski stolnici. Hranjen je v depoju Mestnega muzeja Ljubljana, inv. št. 5ı0:LJU;0048572. Material: Gost temno siv apnenec brez prepoznavnih zrn. Starosti takega apnenca se nedvoumno ne da potrditi, vendar se kot najbolj verjeten izvor ponuja območje Podpeči.

Mere: I 4,5 X 18 x Io cm, višina črk: $6,5 \mathrm{~cm}$.

Opis: Ohranjen je zgornji levi vogal preklade, na katerem lahko preberemo prvi dve črki v celoti in levo polovico tretje.

Neobjavljen.
L oc[us monumenti]

Prevod: Grobna parcela ...

Komentar: Glej komentar pri št. 3.

Datacija: I. st. (?)

\section{Fragment napisnega kamna}

Najdišče: Ljubljana (Emona). Najdiščnih podatkov in podatkov o pridobitvi ni. Hranjen je v depoju Mestnega muzeja Ljubljana, inv. št. 510:LJU;0059824.

Material: Temno siv apnenec z zelo redkimi drobnimi, včasih nekoliko večjimi (fosil polža) zrni. Nabor mikrofosilov ustreza spodnjejurskim združbam. Kamnina najverjetneje izvira iz območja Podpeči.

Mere: 34,5 X 3I x 5,5 cm, višina črk: 6-6,5 (v. I), 4 (v. 2) cm.

Opis: Napisni kamen iz sivega apnenca, prelomljen na polovico. Ohranjeni sta dve vrstici napisa, prva vrstica: „L C“, druga vrstica: „L „ . Ohranjena je leva stran spomenika. Izrazito trikotno ločilno znamenje je med L in C. S starejše fotografije je razvidno, da je kamen danes manjši in tako manjka črka P. Ločilno znamenje pa je bilo tudi med črkama $\mathrm{C}$ in $\mathrm{P}$ v vrstici I. Zdi pa se zelo verjetno, da je trikotno ločilno znamenje tudi v drugi vrstici za črko L.

Neobjavljen.

$$
\begin{aligned}
& \mathrm{L}(\text { oco }) \mathrm{c}(\text { oncesso }) \mathrm{p}(\text { ublice })(?) \\
& \mathrm{L}(---) ?
\end{aligned}
$$

Prevod: ... mesto javno podeljeno ...

Komentar: Podobna formula namreč $L(o-$ co) $d$ (ato) p(ublice) je v Emoni dokumentirana na napisu RINMS iI (prim še. RINMS 73, kjer je najverjetneje izpričan začetek iste formule, spomenik, na katerem je, pa je opravljal funkcijo mejnika). Tudi če je razumevanje na tem mestu izpričane formule pravilno, še vedno ni jasno, kaj predstavlja L v drugi vrstici.

Datacija: 1.- 3. st. 


\section{Fragment napisnega kamna}

Najdišče: Ljubljana (Emona). Pri kopanju kanala za toplovod so pod pragom vzhodnih vrat Škofijskega dvorca našli fragment spomenika z napisom (VS 13-14, I968-1969, 163, slika). Hranjen je v depoju Mestnega muzeja Ljubljana, inv. št. 5IO:LJU;0060I84.

Material: Svetlo siv apnenec s številnimi okroglimi zrni (ooidi). Tovrstna kamnina je znana tudi iz območja Podpeči ${ }^{6}$. Spodnjejursko starost potrjuje mikrofosil (luknjičarka) vrste Meandrovoluta asiagoensis.

Mere: 24 × $62 \times 34 \mathrm{~cm}$, višina črk: $14,5 \mathrm{~cm}$.

Opis: Kvader iz sivega apnenca, ob robovih odlomljen; odlomljen predvsem levo in desno, zgoraj in spodaj deluje nedotaknjeno, razen če je to posledica sekundarne rabe in predelave. Črke so lepe z odebeljenimi zaključki.

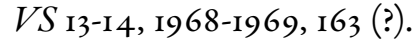

$$
\begin{aligned}
& -----? \\
& {[---] \underline{X} V I+[---]} \\
& -----?
\end{aligned}
$$

\section{Prevod: /}

Pred črko $\mathrm{V}$ je viden ostanek črke (desni spodnji del črke, morda desni del črke X), za črko I pa je prav tako ostanek črke: spodnji del pokončne haste (morda še en I ali $\mathrm{F}$ etc.).

Komentar: Fragment je bil sicer že objavljen v Varstvu spomenikov, a je njegovo stanje danes že drugačno kot takrat: črka X je bila namreč ob prvi objavi skoraj v celoti ohranjena, medtem ko je danes viden samo še njen skrajno desni spodnji del.

Datacija: r./2. stoletje.

\section{Fragment napisnega kamna}

Najdišče: Ljubljana (Emona). Odlomek so našli med arheološkimi raziskavami na Trgu revolucije 16. septembra 1961, v izkopnem polju IV. Hranjen je v depoju Mestnega muzeja Ljubljana, inv. št. $510: L J U ; 0048592$.

\footnotetext{
Luka Gale, "Microfacies characteristics of the Lower Jurassic lithiotid limestone from northern Adriatic Carbonate Platform (central Slovenia)," Geologija 58 (2015): I21-138.
}

Material: Gost temno siv apnenec, mestoma z redkimi drobnimi zrni. Redki mikrofosili kažejo na spodnjejursko starost. Najbolj možen izvor tovrstne kamnine je območje Podpeči ${ }^{7}$.

Mere: 23,5 X I5 X I5 cm, višina črk: $5 \mathrm{~cm}$.

Opis: Odlomek napisnega kamna je zgoraj polkrožno zaključen, odlomljen pa je levo in desno ter spodaj. Ločilno znamenje se predvideva $\mathrm{v}$ prvi vrstici med C (G?) in P; morda je bilo tudi med I in A v drugi vrstici (lahko pa gre tudi za posledico poškodbe); ločilno znamenje tudi med $\mathrm{N}$ in $\mathrm{F} v$ tretji vrstici.

Neobjavljen.

$$
\begin{aligned}
& C(---?) P(---?) \\
& {[---] T I A C[---]} \\
& {[---] N F+[--]}
\end{aligned}
$$

궁 10

Prevod: /

V. 3: Pred črko N, morda I, za črko F morda črka E ali R. če je zadnja črka res R, potem bi morda lahko prebrali in fronte (pedes).

Komentar: Zaradi same oblike kamna in verjetne vsebine tretje vrstice, se zdi, da gre tudi v tem primeru za mejnik grobne parcele, pri čemer pa ni mogoče pojasniti prvih dveh vrstic. Zdi se sicer malo verjetno, da bi bila pred prvo črko izpričana še ena črka, a če bi bila, potem bi lahko pričakovali črko L. Na ta način bi se ponovno srečali s formulo $L($ oco) c(oncesso) p (ublice) (glej št. 5).

Datacija: 1.-3. st.

\section{Fragment nagrobne plošce}

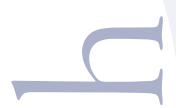

Najdišče: Ljubljana (Emona). Najdiščnih podatkov in/ali podatkov o pridobitvi ni. Po mnenju Božene Dirjec kamen morda izvira ali iz najdišča OŠ Majda Vrhovnik ali Trg revolucije ali Nunski zid. Hranjen je v depoju Mestnega muzeja Ljubljana, inv. št. 5IO:LJU;005ı18I.

Material: Temno siv apnenec s plavajočimi belimi lupinami školjk. Med njimi so tudi lupine litiotidnih školjk, ki so diagnostične za sred-

\footnotetext{
Gale, "Microfacies characteristics of the Lower Jurassic lithiotid limestone from northern Adriatic Carbonate Platform (central Slovenia)."
} 
nje spodnjejursko starost. Tovrstni apnenec se nahaja tudi na območju Podpeči ${ }^{8}$. Spodnja in zgornja stran nagrobne plošče verjetno predstavljati neobdelano površino plasti $\mathrm{z}$ naravno debelino $12-15 \mathrm{~cm}$.

Mere: $42 \times 67$ x I5 cm, višina črk: 4,5 (v. I), $5,5($ v. 2$) \mathrm{cm}$.

Opis: Ohranjen je osrednji del plošče z ostankoma dveh vrstic, ki je najverjetneje odlomljen $\mathrm{z}$ vseh strani. Branje je zaradi poškodb na površini kamna zelo težavno. Ločilno znamenje je še vidno med $A$ in $C$ v prvi vrstici.

Neobjavljen.

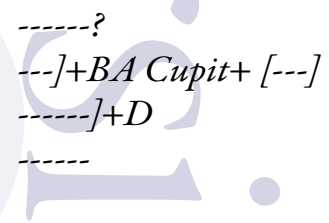

Prevod: ... Kupit (?) ...

V. I: Pred črko B je še viden ostanek črke (morda C, D ali L). Prav tako za črko T ostanek črke - morda levi zgornji del črke V.

V. 2: Na koncu vrstice lepo vidna črka D, pred njim morda še I.

Komentar: v prvi vrstici je ohranjena večina imena Cupitus/-a, pri čemer ni jasno, če gre za žensko ali moško različico imena. Ime Cupitus, ki sodi k skupini imen, ki so tvorjena iz latinskega participa perfekta (iz glagola cupio želim, hrepenim, zahtevam). Sledimo mu lahko po območjih, ki so poseljena s keltskim prebivalstvom, najpogosteje se nahaja v Noriku. Razlog za veliko število izpričanih primerov prav na tem ozemlju lahko morda iščemo v izgovarjavi, ki je bila sorodna keltskim imenom na Cou-ali $\mathrm{Cob}_{-}{ }^{-}$.

Datacija: 2./3. st.

\section{Fragment napisnega kamna}

Najdišče: Ljubljana (Emona). Najdiščnih podatkov ali podatkov o pridobitvi ni. Hranjen

8 Gale, "Microfacies characteristics of the Lower Jurassic lithiotid limestone from northern Adriatic Carbonate Platform (central Slovenia)."

Primer Lochner von Hüttenbach, Die römerzeitlichen Personennamen der Steiermark: Herkunft und Auswertung, 66; OPEL III, 97. je v depoju Mestnega muzeja Ljubljana, inv. št. 510:LJU;0059823.

Material: Zelo luknjičast in lahek drobnozrnat apnenec s številnimi močno fragmentiranimi fosili, med katerimi so tudi koščki rdečih alg iz skupine Corallinaceae. Apnenec je terciarne starosti. Trenutno poznan potencialni rimski kamnolom se je nahajal na območju Moravč, možen izvor pa je tudi v okolici Kamnika ${ }^{\text {IO }}$.

Mere: 15 X 27,5 X $9 \mathrm{~cm}$, višina črk: $4 \mathrm{~cm}$.

Opis: Fragment napisne plošče, ki je odlomljena z vseh strani. Če je bilo napisno polje omejeno in poglobljeno, ni več mogoče ugotoviti, je pa desni del napisnega polja zlizan, obrabljen in zato praktično nečitljiv. Vidne so štiri vrstice napisa, $s$ tem da v prvi in zadnji razberemo le ostanke črke, ki jih ni več mogoče prepoznati. Podobno velja tudi za ločilna znamenja: če so bila uporabljena, zdaj več niso vidna. Črke delujejo neenakomerne, preproste.

Neobjavljen.

$$
\begin{aligned}
& +++ \\
& {[--] \text { vivo (?) [---] }} \\
& \text { [--]O tibe (!) A+[---] } \\
& \text { [---] } \underline{\underline{V N}[---]}
\end{aligned}
$$

-...--

Prevod: ... za življenja (?) ... tebi ...

V. r.: Vidni neprepoznavni ostanki treh črk.

V.3.: Morda bi lahko šlo za osebni zaimek tibi, ki bi bil zapisan z napako (tibe).

Komentar: Preproste že skoraj rustikalne črke kažejo na preprost nagrobni napis konca 2. oz. 3. stoletja., kar bi lahko potrjeval tudi zapis osebnega zaimka za drugo osebo v obliki tibe namesto v pravilni tibi.

Datacija: 2./3. st.

Fragment nagrobnega (?) spomenika

Najdišče: Ljubljana (Emona). Najdiščnih podatkov in podatkov o pridobitvi ni. Hranjen je v depoju Mestnega muzeja Ljubljana, inv. št. 510:LJU;0055255.

Io Djurić in Rižnar, "Kamen Emone," 12 1-143. 
Material: Svetlo siv zrnat apnenec s posamičnimi večjimi fosili (odlomki školjk). Med zrni prevladujejo fosili in zrna erodiranega sedimenta. Za starost kamnine diagnostični fosili niso bili najdeni, vendar bi lahko šlo za kamnino kredne starosti (primerjaj s predmetom inv. št. 5IO:LJU;0048569).

Mere: 10 x 28,5 x $45 \mathrm{~cm}$, višina črk: $6,5 \mathrm{~cm}$.

Opis: Preklada? z lepimi elegantnimi črkami, odlomljena z vseh strani (?). Zdi se, da je pred črko V ohranjeno ločilno znamenje. Prav tako se zdi, da so črke vklesane na plitko klesano črto.

Neobjavljen.

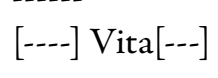

Prevod: ... Vita[---] ...

Komentar: Na napisih so razmeroma redki primeri, ko srečamo samostalnik vita, a kakšnega je vendarle mogoče najti, prim. HDooo842. Bolj verjetno se tako zdi, da je "naša VITA" samo začetek pogosto izpričanega imena Vitalis, prim. $H D$ - passim, OPEL IV, 176-177.

Datacija: I. / 2. st.

\section{Fragment nagrobnega spomenika (?)}

Najdišče: Ljubljana (Emona). Fragment so našli leta 2009 v okviru izkopavanj na Kongresnem trgu, v sektorju I/J26, SE 3377 (PN3683). Hranjen je v depoju Mestnega muzeja Ljubljana, inv. št. 5 IO:LJU;0062942.

Material: Močno preperel kalcitni marmor z malo sljude zeleno-zlate barve. Izvor ni opredeljen.

Mere: 5,2 X $20 \times 17 \mathrm{~cm}$, višina črk: $8 \mathrm{~cm}$.

Opis: Fragment je odlomljen z vseh strani, ohranjene so samo tri velike in elegantne črke, ki predstavljata ostanek dveh vrstic napisa. Med črkama I in F je ohranjeno ločilno znamenja. V drugi vrstici je vidna črka $\mathrm{V}$, desno od nje pa še ostanek (odebeljeni zaključek) leva zgornjega dela ene črke. Črke so bile klesane globoko, lepo so še vidni njihovi odebeljeni zaključki. Med ohranjenim vrsticama je bila vklesana vodoravna črta.

Neobjavljen.

$$
\begin{aligned}
& {[--] I F[--]} \\
& {[--] V+[--]}
\end{aligned}
$$

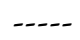

\section{Prevod: /}

Komentar: Material (marmor) in kvalitetno klesane elegantne črke dajejo slutiti, da bi tudi ta fragment lahko bil del pomembnejšega, morda celo cesarskega napisa. V prvi vrstici bi ohranjeni črki lahko govorili o filiaciji; I kot zadnja črka imena v genetivu, F kot začetek besede $f$ lius.

Datacija: I./2. stoletje.

\section{Zaključki}

Preiskali smo in odlomkov prvotno kamnitih predmetov $\mathrm{z}$ napisi, ki predstavljajo dele nagrobnih spomenikov in mejnikov grobnih parcel. Zaradi fragmentarne narave preiskanih kosov so ohranjeni le deli besedil, ki pa vseeno nakazujejo prvotno rabo oziroma namen. Mejniki in del nagrobnikov je bil izklesan iz spodnjejurskega apnenca, za katerega domnevamo, da so ga lomili pri Podpeči, torej v neposredni okolici Ljubljane. Prav tako iz bližine Ljubljane (domnevno okolica Moravč) izvira nagrobnik s preprostimi, rustikalnimi črkami, ki je bil izdelan iz miocenskega apnenca. Ker slednji apnenec hitro propada, je verjetno šlo za cenejši nagrobnik, kar se ujema s preprosto klesanimi črkami. Nasprotno so vsi preiskani artefakti z umetelno oblikovanimi črkami izdelani iz kamnin, ki jih ne najdemo v bližini Ljubljane - iz apnenca kredne starosti in iz marmorja. Morda gre za nagrobne spomenike premožnejših družin, ki so lahko kupile dražje, a obstojnejše in estetsko lepše nagrobnike. 


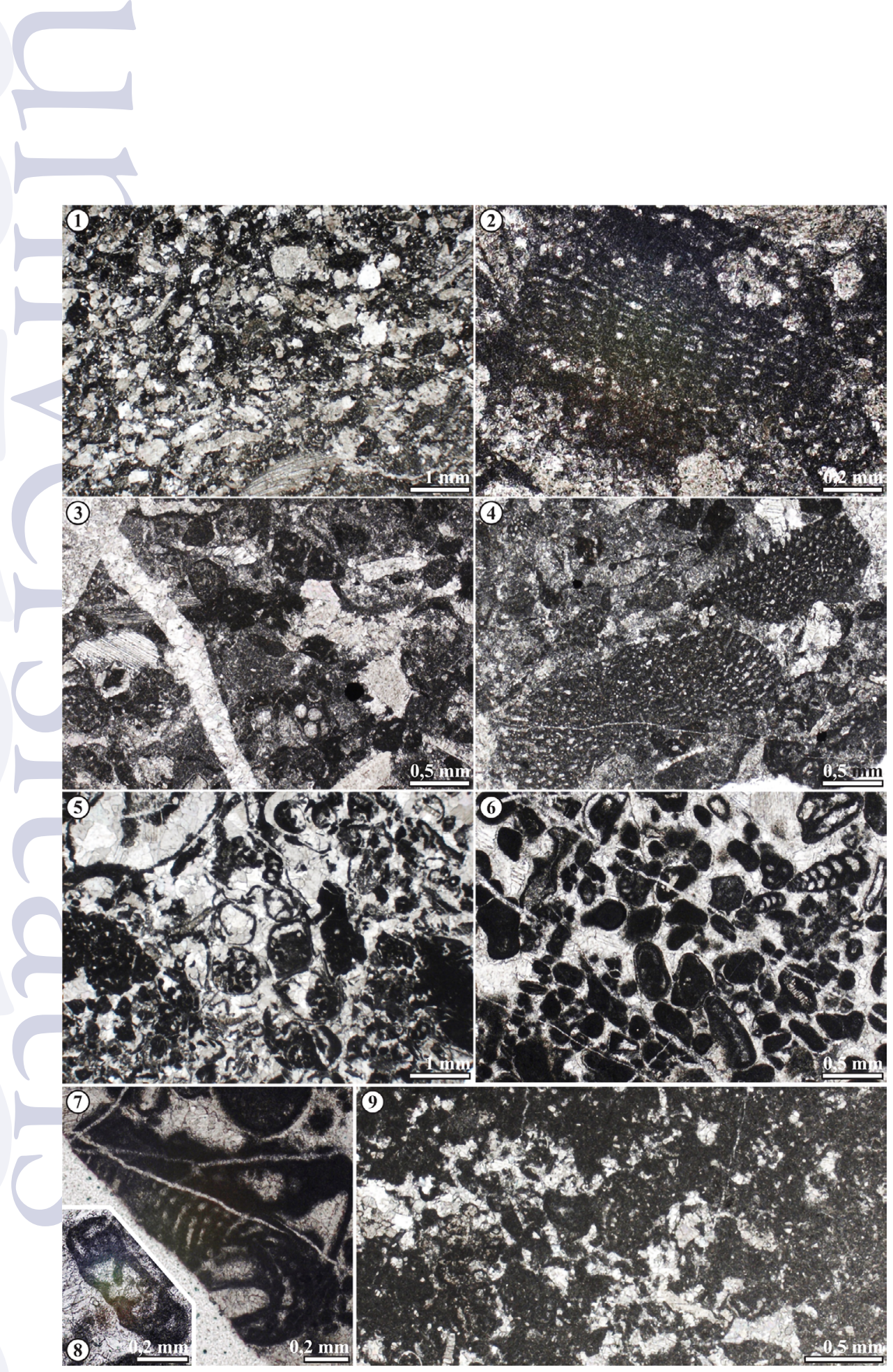

Slika I: Mikrofacies in fosili vzorčenih artefaktov. I: Bioklastični intraklastični packstone. Puščica kaže na fragment školjke. Artefakt sı:LJU;0048569. 2: Fragment nedoločene foraminifere. Artefakt 510:LJU;0048569. 3: Bioklastični intraklastični packstone. Artefakt 510:LJU;0055255. 4: Foraminifere naddružine Orbitolinoidea (O). Artefakt 510:LJU;0055255. 5: Bioklastični intraklastični grainstone. Puščica kaže na prekristaljeno hišico polža. Artefakt 510:LJU;0060180. 6: Peloidni grainstone. Črna puščica kaže na foraminifero, bela puščica na fragment lupine mehkužca z mikritiziranim robom. Artefakt j10:LJU;0060203. 7: Foraminifera Orbitopsella primaeva Henson. Artefakt 510:LJU;0060203. 8: Foraminifera Everticyclammina praevirguliana Fugagnoli. Artefakt 510:LJU;0060203. 9: Delno spran mudstone z redkimi klasti. Črka P označuje fekalni pelet. Artefakt sro:LJU;0059824. 

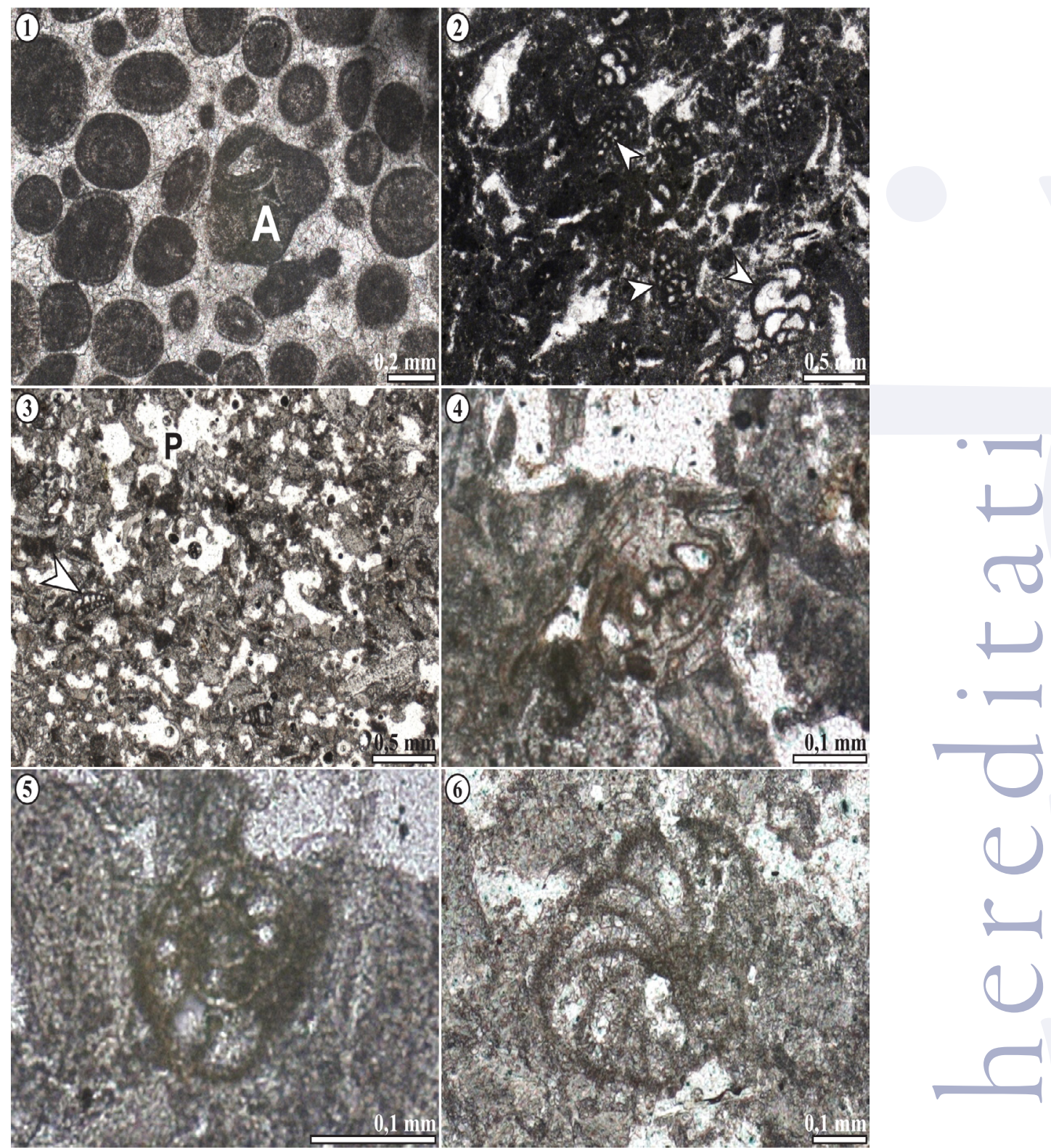

Slika 2: Mikrofacies in fosili vzorčenih artefaktov. I: Ooidni grainstone s posamičnimi agregatnimi zrni (A). Artefakt 5ı:LJU;0060184. 2: Bioklastični wackestone. Puščice kažejo na številne foraminifere. Artefakt 510:LJU;0048592. 3: Delno spran bioklastični packstone. Črka P označuje številne pore nepravilnih oblik. Puščica kaže na drobno foraminifero. Artefakt 510:LJU;0059823. 4-6: Nedoločene foraminifere. Artefakt 510:LJU;0059823. 
Tabela ı: opisi kamnine.

\begin{tabular}{|c|c|c|c|}
\hline Inv. št. artefakta & Opis kamnineı & Barva2 & Slika \\
\hline 510:LJU;००48569 & $\begin{array}{l}\text { Bioklastični intraklastični packstone s srednje dobro sortiranost- } \\
\text { jo zrn. Povprečna velikost zrn je okrog o,5 mm. Redka zrna (lupine } \\
\text { školjk) merijo II mm ali več. Med zrni prevladujejo bioklasti ( } 21 \% \\
\text { površine predstavljajo ploščice iglokožcev, } 6 \% \text { je fragmentiranih } \\
\text { lupin školjk, zelo malo je nedoločenih foraminifer in mahovnjak- } \\
\text { ov) in mikritni intraklasti ( } 22 \% \text { \%). Osnova je kalcisiltitna, z veliko } \\
\text { neprepoznavnih drobcev bioklastov. Ploščice iglokožcev obdaja } \\
\text { sintaksialni kalcitni cement. }\end{array}$ & Svetlo olivno siva (5Y 6/l) & Tab. I, sl. I-2 \\
\hline 510:LJU;0055255 & $\begin{array}{l}\text { Artefakt je izdelan plasti apnenca, debeline vsaj } 12 \mathrm{~cm} \text {. Apnenec je } \\
\text { heterogen, saj sta makroskopsko opazna } 2 \mathrm{~cm} \text { debel horizont do- } \\
\text { bro sortiranega packstone-a in Io cm debel horizont packstone-a } \\
\text { s pogostimi ploščicami krinoidov. Makroskopsko so bili opaženi } \\
\text { še zelo drobna (o,2 mm veliki) počrnela zrna. S pomočjo zbrus- } \\
\text { ka je debelejši horizont opredeljen kot intraklastični bioklastični } \\
\text { packstone s slabo do srednje dobro sortiranostjo zrn. Ta imajo po } \\
\text { večini oglate robove in so v točkastih stikih. Prevladujejo mikrit- } \\
\text { ni intraklasti in peloidi (okrog } 33 \% \text { površine). Sledijo fragmenti } \\
\text { školjčnih lupin (6\%) in ploščice iglokožcev ( } 5 \% \text { ), obdane s sintak- } \\
\text { sianim kalcitnim cementom. Manjši delež zrn predstavljajo ma- } \\
\text { hovnjaki in bentoške foraminifere. Med slednjimi so prepoznavne } \\
\text { kupolaste foraminifere z aglutinirano steno iz naddružine Orbi- } \\
\text { tolinoidea. Medzrski prostor večinoma zapolnjuje mikritno vezi- } \\
\text { vo (kalcisiltit). }\end{array}$ & $\begin{array}{l}\text { Srednje siva } \\
\left(\mathrm{N}_{5}\right)\end{array}$ & Tab. I, sl. 3-4 \\
\hline
\end{tabular}

Preko artefakta poteka kompakcijski stilolit, ki loči temno siv mikritni apnenec in zrnat apnenec s svetlejšimi klasti. Makroskopsko so prepoznavne manjše leče o,5-I cm velikih školjk. Zrnat apnenec je bioklastični intraklastični grainstone in delno spran packstone. Intraklasti (deloma peloidi) predstavljajo veči510:LJU;0060180 no zrn. So polzaobljeni do oglati, v točkastih stikih. Večina je velikih med o,25 in $0,35 \mathrm{~mm}$. Poleg njih so prisotne redkejše bentoške

Srednje siva $\left(\mathrm{N}_{5}\right)$ Tab. I, sl. 5 foraminifere $z$ aglutinirano steno, drobni fragmenti lupin mehkužcev (prepoznavna je neomorfno nadomeščena hišica polža velikosti okoli $3 \mathrm{~mm}$ ) in mikroproblematika Thaumatoporella parvovesiculifera (Raineri). Sprane dele zapolnjuje mozaični kalcitni cement.

Apnenec je peloidni grainstone. Zrna so v točkastih kontaktih, po večini polzaobljena, nekatera tudi oglata ali dobro zaobljena. Sortiranost je slaba do srednje dobra. Srednja velikost zrn je $0,35 \mathrm{~mm}$. Poleg peloidov, ki prevladujejo, so prisotna še agregatna zrna, močno mikritizirani ooidi, bentoške foraminifere ter drobci lupin mehkužcev (z mikritnim robom ali mikritnim ovojem).

510:LJU;0060203 Nekatera zrna so obdana z enim ali dvema ooidnima ovojema. Med foraminiferami so bile prepoznavne vrste: Everticyclammina praevirguliana Fugagnoli, Meandrovoluta asiagoensis Fugagnoli \& Rettori, Orbitopsella primaeva Henson, Mesoendothyra? sp. and Trocholina? sp. Medzrnski prostor zapolnjuje druzimozaični kalcitni cement. Na redkih zrnih je mestoma moč opaziti še obrobni vlaknati kalcitni cement.

Srednje siva

$\left(\mathrm{N}_{5}\right)$

Tab. I, sl. 6-8

Makroskopsko lahko prepoznamo več svetlo rjavih kompakci-

5IO:LJU;0048572 jskih stilolitov z medsebojno razdaljo 2-4 cm. Apnenec je temno siv mudstone, brez vidnih zrn. 
Kamnina je s svetlo rjavimi stiloliti razdeljena v več $\mathrm{I}-3 \mathrm{~cm}$ debelih horizontov. Apnenec je močno spran temno siv mudstone z redkimi bioklasti. Od slednjih so prepoznavni slabo viden fekalni pelet, 510:LJU;0059824 mikroproblematika Thaumatoporella parvovesiculifera (Raineri), Ammobaculites sp. in druge drobne aglutinirane foraminifere ter preproste foraminifere skupine Lagenida, ostrakodi, drobni polži ter drobni fragmenti, ki domnevno pripadajo lupinam mehkužcev. Sprane dele zapolnjuje mozaični kalcit.

Apnenec je ooidni grainstone. Več različkov (horizontov) se loči po velikosti, gostoti in sortiranosti ooidov. Zbrusek je bil narejen iz dela z zelo dobro sortiranimi ooidi srednje velikosti $0,38 \mathrm{~mm}$ (največji ooid meri o,55 mm). Ooidi imajo tangencialno zgradbo, 510:LJU;0060184 a so nekoliko prekristaljeni. Prepoznanih je bilo okoli 22 ovojev. Jedro (peloid, drobne foraminifere, ploščice iglokožcev, neprepoznavni bioklasti) zavzema okoli tretjino velikosti ooida. Poleg ooidov so prisotna redka agregatna zrna in zelo redke drobne aglutinirane foraminifere. V ooidu je bila prepoznana vrsta Meandrovoluta asiagoensis Fugagnoli \& Rettori.

Srednje siva

$\left(\mathrm{N}_{5}\right)$

Tab. 2, sl. I

Vzorec lahko opredelimo kot bioklastični wackestone. Od redkih bioklastov so prepoznavni fragmenti školjk in foraminifere (vrste ?Haurania deserta Henson, Meandrovoluta asiagoensis Fugagnoli \& Rettori; poleg so še neprepoznavni ostanki drugih aglutiniranih vrst, tudi tistih z notranjimi stebrički). Na večjem merilu lahko vidimo, da v gostem mikritnem apnencu nastopajo tudi manjše leče z več klasti. Med njimi so vidni kortoidi, polži, intraklasti in foraminifere.

Artefakt je izdelan iz tanjše (I2-15 cm debele) plasti temno sivega apnenca s plavajočimi lupinami megalodontidnih školjk. Na eni (zgornji ali spodnji) strani vsebuje tudi daljše lupine litiotidnih školjk. Te v plasti ležijo subhorizontalno. Apnenec je teksturno tipa floatstone. Večjo komponento predstavljajo lupine školjk. Lupine so bioerodirane, na robovih močno mikritizirane in na510:LJU;0051181 domeščene z druzimozaičnim kalcitom. Vezivo je drobnozrnato, mikritno ali kalcisiltitno. Od drobnih bioklastov so prepoznavne aglutinirane (vključno z ?Duotaxis metula Kristan), lagenidne foraminifere in ?Earlandia sp., drobne bodice morskih ježkov, mikroproblematika Thaumatoporella parvovesiculifera (Raineri) ter drobni paličasti bioklasti, ki domnevno predstavljajo koščke školjčnih lupin.

Mehek in lahek apnenec bež barve vsebuje nekaj večjih fosilov, med katerimi je makroskopsko moč prepoznati do $0,5 \mathrm{~cm}$ velike odlomke ostrig, mahovnjakov, serpulidov in celo koničast zob ribe kostnice. Apnenec je zelo porozen bioklastični packstone. Večje nepravilne pore predstavljajo kar 30 \% kamnine. Preostanek 510:LJU;0059823 tvori zelo drobnozrnata apnenčasta osnova (kalcisiltit), močno fragmentirani oglati bioklasti (drobne planispiralne in trohospiralne rotalidne in tekstularidne foraminifere, iglokožci, fragmenti rdečih alg skupine Corallinales, ostrakodi, drobni fragmenti lupin mehkužcev) ter pelodi (veliko jih verjetno predstavlja mikritizirane koščke koralinej).

510:LJU;0062942 Kalcitni marmor z okoli $5 \%$ lističev olivno zeleno-zlate sljude.

Robert J. Dunham, "Classification of carbonate rocks according to depositional texture," in Classification of carbonate rocks, A symposium, ur. Ham W. E. (Tulsa: American Ass. Petrol. Geol., 1962), 108-12 I.

2 Munsell, Rock-color chart (The Geological Society of America, 8th printing, 1995). 


\section{Povzetek}

Prispevek predstavlja epigrafsko analizo napisov, ki so ohranjeni na enajstih še neobjavljenih odlomkih nagrobnikov in mejnikov grobnih parcel z območja rimske Emone. Vsi kamniti spomeniki z napisi so bili najverjetneje odkritiv sekundarni legi in izvirajo iz obdobja od ı. do 3. stol. n. št. Litološka analiza kamnin, iz katerih so bili izdelani artefakti kaže, da so bili mejniki in nekateri od nagrobnih napisov izdelani iz jurskega apnenca, domnevno iz območja današnje Podpeči pri Ljubljani. Tovrstni apnenec je bil na prostem razmeroma obstojen. Eden od fragmentov vsebuje neenakomerno velike in preproste črke, klesane v slabo obstojen miocenski apnenec, ki bi lahko prihajal iz okolice Moravč. Tovrstni material je bil slabe kvalitete in zato verjetno cenejši. $\mathrm{Na}$ sprotno so najlepše oblikovane črke klesane v (verjetno) kredni apnenec in marmor, ki ju ne najdemo v neposredni bližini Ljubljane, zaradi česar sklepamo, da so bili tovrstni spomeniki najdražji. Naročniki so ju domnevno izbrali zaradi obstojnosti in/ali estetske vrednosti (homogen izgled, skoraj bela barva).

\section{Summary}

Eleven inscriptions, discovered on as yet unpublished fragments of funerary stelae and boundary stones of burial plots from the territory of Roman Emona, are discussed in this contribution. The monuments with inscriptions, kept in the City Museum of Ljubljana, were most probably discovered in the secondary position and date to the period from the ist till the 3 rd century AD. The lithological analysis of stone that the artefacts were made of indicates that grave plot markers and some stelae were made of Jurassic limestone, presumably originating from the area of Podpeč near Ljubljana. This kind of limestone is relatively durable in the open air. One of the fragments displays large and simple letters inscribed into less durable Miocenic limestone that could come from the Moravče area. The poor quality of this kind of limestone presumably made it cheaper. Other fragments, with beautifully-formed letters incised into the (probably) Cretaceous limestone and marble, are quite the opposite. Those rocks cannot be found in the area around Ljubljana, which makes these products expensive. They must have been desired for their durability and/or aesthetics (homogenous surface, almost white colour).

\section{Literatura}

HD: Epigraphische Datenbank Heidelberg (skrbnik/Service provider: Heidelberger Akademie der Wissenschaften). http:// edh-www.adw.uni-heidelberg.de/ home?\&lang=de (zadnji dostop: 2I. 3 . 2017).

ILJug: Ana in Jaroslav Šašel, Inscriptiones Latinae quae in Ingoslavia inter annos ... repertae et editae sunt: Situla 5 (1963); Situla 19 (1978); Situla 25 (1986).

OPEL: Onomasticon provinciarum Europae

Latinarum. Ex materia ab A. Mócsy,

R. Feldmann, E. Marton et M. Szilágy collecta. Composuit et correxit B. Lőrincz. Vol. I: Aba-Bysanus, Budapest 2005. Vol. II: Cabalicius-Ixus, Wien 1999. Vol. III: Labarum-Pythea, Wien 2000. Vol. IV: Quadratia-Zures, Wien 2002. RINMS: Šašel Kos, Marjeta. Lapidarij Narodnega muzeja Slovenije / The Roman Inscriptions in the National Museum of Slovenia. Situla 36 (1997).

Boudager-Fadel, Marcelle. K. Evolution and geological significance of larger benthic foraminifera. Developments in Palaeontology and Stratigraphy 22. Amsterdam: Elsevier, 2008.

Djurić, Bojan in Igor Rižnar. "Kamen Emone.

“V EMONA MM, Urbanizacija prostora

- nastanek mesta, ur. Bernarda Županek, I2 I-I 43. Ljubljana: ZVKDS, MGML, 2017.

Dunham, J. Robert. "Classification of carbonate rocks according to depositional texture." In Classification of carbonate rocks, A symposium, ur. Ham W. E., Io8-I2r. Tulsa: American Ass. Petrol. Geol., 1962.

Gale, Luka. Microfacies characteristics of the Lower Jurassic lithiotid limestone from northern Adriatic Carbonate Platform (central Slovenia). Geologija 58 (2015): I2II38.

Kajanto, Iiro. The Latin Cognomina

(Helsinki: Societas Scientiarum

Fennica. Commentationes Humanarum

Litterarum, XXXVI 2, 1965). 
Lochner von Hüttenbach, Fritz. Die römerzeitlichen Personennamen der Steiermark: Herkunft und Auswertung (Graz, 1989).

Meid, Wolfgang. Keltische Personennamen in Pannonien (Budapest: Archaeolingua, 2005).

Munsell, Rock-color chart. The Geological Society of America, 8th printing, 1995.

Ramovš, Anton. Podpeški in črni ter pisani lesnobrdski apnenec skozi čas (Ljubljana: Mineral, 2000). I3-I 4 (1968-1969): I62-I63.

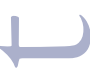




\title{
I cambiamenti etnici sulla penisola Italica dalla guerra sociale alla morte dell' imperatore Augusto
}

\author{
Jadranka Cergol, Università del Litorale, Facoltà di studi umanistici
}

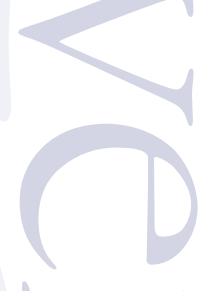

Cilj prispevka je predstaviti na podlagi starogrških in latinskih zgodovinskih virov spremembe v etnični sestavi italskega polotoka v prvem stoletju pr. Kr., natančneje od zavezniške vojne (9I - 88 pr. Kr.) do Avgustove smrti (I4 po Kr.). Zgodovinski viri iz republikanske dobe predstavljajo namreč italska ljudstva kot ostre nasprotnike nadvladi rimskega mesta, nasprotno pa, viri iz cesarske dobe opisujejo ista ljudstva kot bratska ljudstva Rimljanom. Potrebno je tudi poudariti ugotovitev, da po Avgustovi smrti imena Etruščanov, Sabinov, Umbrov, Samnitov in drugih niso več uporabljena v rimskem zgodovinopisju in polagoma izginjajo iz političnih zemljevidov italskega polotoka: ostanejo samo Rimljani in Italiki, ostane samo Italia kot enotna dežela. Kljub izkoreninjenju italskih ljudstev pa so nekatera od teh, npr. Etruščani, znatno obogatili rimsko družbo s svojimi kulturnimi značilnostmi.

Ključne besede: etnična identiteta, Italiki, rimska zgodovina, Avgust, Etruščani, Samniti

Lo scopo principale del contributo è illustrare sulla base di fonti greche e latine i cambiamenti della composizione etnica sulla penisola italica nel primo secolo a. C., più precisamente dalla guerra sociale (9I-88 a. C.) alla morte di Augusto ( 14 d. C.). Le fonti storiche di età repubblicana, infatti, descrivono le popolazioni italiche come acerrime nemiche che avevano combattuto contro Roma, mentre quelle di età imperiale parlano di popolazioni che erano addirittura consanguinee ai Romani. Bisogna anche notare che dopo la morte di Augusto i nome degli Etruschi, Sabini, Umbri, Sanniti e altri non vengono più utilizzati dalla storiografia romana perché queste popolazioni scompaiono dalla cartina geografica e politica della penisola italica: rimangono soltanto i Romani e gli Italici, rimane soltanto l'Italia come un unica regione. Nonostante l'estirpazione delle popolazioni italiche però alcuni gruppi etnici, come gli Etruschi, arricchirono essenzialmente la storia e la società romana con le proprie componenti culturali.

Parole chiave: identità etnica, Italici, storia romana, Augusto, Etruschi, Sanniti

$\mathrm{N}$

egli ultimi decenni si può notare un nuovo interesse nella ricerca delle questioni etniche anche nel campo degli studi sull'antichità. La teoria strumentale, che si basava sulla convinzione che il sentimento di appartenenza etnica fosse soltanto un pretesto per conseguire risultati politici o economici, ${ }^{\mathrm{I}}$ è risul-

Donald L. Noel, "A Theory of the Origin of Ethnic Stratification". Socialproblems 16, no. 2 (1968): 28-34. tata essere insufficiente. Negli anni '70 e '8o del secolo scorso si è quindi avuta una rinascita delle ricerche antropologiche sulla questione dell'appartenenza etnica. La questione dei gruppi etnici nell'antichità pone il ricercatore moderno dinanzi a un gran dilemma, in quanto già i termini stessi come nazione o popolo, utilizzati per l'appartenenza etnica, sono concetti implicitamente radicati che si sono affermati appena dal XVII 
secolo in poi e quindi si adattano con difficoltà alla concezione di ethnos nell'antichità. Nonostante tutte queste perplessità e questi ostacoli, secondo i ricercatori contemporanei si può parlare di appartenenza etnica anche nel contesto dell'antichità classica, in quanto sia in Grecia, sia nell'impero Romano e altrove nel Mediterraneo, le persone si incontravano, si univano, combattevano in guerre anche in base al principio di etnia. ${ }^{2}$ Un'analisi sociale e storica approfondita sull'origine delle popolazioni può quindi contribuire a una comprensione migliore dei sentimenti e dei legami che le identità culturali collettive costruiscono nel corso di molte generazioni. ${ }^{3}$

Per la definizione del gruppo etnico saranno addottati come criteri principali quelli definiti da Anthony Smith che ne elenca sei: nome comune, mito comune di origine, memoria storica comune, cultura comune, appartenenza ad un dato territorio e il senso di solidarietà comune. ${ }^{4}$

\section{Definizione del problema}

Nel periodo del principato di Augusto ci furono importanti cambiamenti nel campo delle questioni etniche: la politica interna del princeps, infatti, tendeva all'unificazione di tutte le genti italiche in un'unica unità politica. Il contributo si propone di esaminare prima l'inquadramento storico-politico dei fatti accaduti, ma soprattutto analizzare come l'unificazione etnica della penisola venisse percepita sia dai Romani che dalle varie popolazioni italiche: come esempio saranno esaminati i casi degli Etruschi e dei Sanniti.

La penisola italica è stata nel corso dell'espansione dello stato romano abitata da varie popolazioni diversamente sviluppate sul piano eco-

2 Erich Gruen, Culture and National Identity in Republican Roma (New York: Ithaca, 1984); Kathrin Toll, "Making Roman-ness and the Aeneid", Classical Antiquity" 16 (1997): 34-56; Lucia Aigner-Foresti, "Quod discinctus eras, animo quoque, carpitur unum « (Maec., El. 1.21)", Contributi dell'stituto di Storia Antica 17 (1991): 201-214; Jonatan M. Hall, Ethnic Identity in Greek Antiquity (Cambridge: Cambridge Core, 1997); Yasmin Syed, Vergil's Aeneid and the Roman Self (Ann Arbor: The University of Michigan Press, 2005); Gary D. Farney, Ethnic identity and aristocratic Competition in Republican Rome (Cambridge: Cambridge University Press, 2007).

3 Anthony D. Smith, The Ethnic Origins of Nations (Oxford: Blackwell Publishers, 1986).

4 Smith, The Ethnic Origins, 66-83. nomico, culturale, politico e sociale. Per l'epoca arcaica è molto difficile tracciare un quadro etnico preciso, perché le fonti sono incerte e tra di loro discordanti. Rimane comunque un fatto indiscusso che la penisola italica fu ancora nel terzo secolo a. C., quando i Romani avevano in un modo o nell'altro ottenuto il controllo politico su tutta la penisola, un territorio etnico misto. Se da una parte Roma manteneva il controllo sugli Etruschi soprattutto tramite accordi politici e forti collegamenti con l'aristocrazia etrusca, con i Sanniti dovette combattere numerose battaglie ${ }^{5}$. L'espansione del popolo romano però non fu sempre efficace; i Romani dovettero spesso scontrarsi con le popolazioni italiche autoctone che riuscivano a volte a fermare la loro affermazione con rivolte organizzate. Gli scontri tra $i$ Romani e le singole popolazioni risalgono già a epoche più remote, ma la prima grande battaglia si ebbe nel 295 a. C. (battaglia del Sentino), quando una confederazione anti-romana, formata da più tribù italiche, si ribellò ai Romani. I fautori della ribellione furono i Sanniti, ai quali però si aggiunsero gli Etruschi, parte degli Umbri e alcuni Galli; la confederazione è stata formata dalle popolazioni che vivevano a nord e a sud di Roma per attaccare la città da entrambe le direzioni. A causa delle dinamiche la battaglia venne da alcuni ricercatori chiamata anche "la battaglia delle nazioni” (ad es. G. Bandelli ${ }^{6}$ ), dato che alcune popolazioni italiche di diversa origine etnica si sono alleate contro un nemico comune - il popolo romano. Nella battaglia gli italici furono sconfitti, Roma invece continuò nella sua politica espansionistica sulla penisola italica.

Nonostante l'efficiente forza politica romana, alcune popolazioni italiche mantenevano in gran parte la propria autonomia con differenze evidenti da regione a regione; le principali diversità tra queste popolazioni era una più o meno sviluppata autocoscienza e il senso di apparte-

Guido Clemente, Guida alla storia romana (Milano: Mondadori, 2001); Kathryn Lomas: Roman Italy: 338 BC - AD 200 (London: Ruotledge, 1996).

Gino Bandelli: "La politica romana nell'Adriatico orientale in età repubblicana", in Seminario storico-archeologico su "L'arco adriatico in età romana e altomedievale" (Trieste, 1986): 168-214. 
nenza al proprio gruppo etnico e la preservazione delle proprie tradizioni, e questo soprattutto dopo l'assoggettamento da parte dello stato romano.

Ciò che possiamo sicuramente affermare sul processo di romanizzazione è che di cruciale importanza fu proprio il periodo tra la guerra sociale e la morte di Augusto - periodo, durante il quale il latino diventò la lingua predominante e durante il quale molte tradizioni culturali vennero introdotte nell'idea di romanitas, che si rispecchia nel sempre più alto grado di assimilazione tra gli aristocratici romani e italici. Bisogna rilevare che la romanizzazione non fu un processo unilaterale (...), si può citare territori, sui quali gli ltalici segnarono la cultura romana. ${ }^{7}$

Possiamo dedurre che il processo della lenta romanizzazione ottenne il suo scopo appena all'inizio del principato di Augusto che nelle proprie Res gestae scrisse: "Iuravit in mea verba tota Italia sponte sua ${ }^{8}$ - il primo imperatore romano aveva quindi l'idea che l'Italia fosse diventata un'unità politica e culturale omogenea o almeno questo era quello che voleva fare credere.

La conquista della penisola italica rappresentava un progetto a lungo termine, i Romani suggellavano con le popolazioni sottomesse vari tipi di rapporti, perché l'annessione dei territori conquistati all'ager romanus non era possibile. La soluzione più spesso trovata era di siglare dei patti con l'aristocrazia locale e così lasciare l'autonomia al territorio, assicurandosi però il controllo politico. Solo raramente i Romani erano costretti ad assoggettarsi direttamente le popolazioni sconfitte e mantenere il controllo diretto sul territorio. Questo succedeva principalmente con le popolazioni che si opponevano più a lungo e più aspramente. La forma più diffusa di assegnazione dei diritti politici era la fondazione di colonie, cioè città, nelle quali gli abitanti erano principalmente cives sine suffragio, cioè cittadini romani senza diritto di voto, a differenza dei $c i$ -

\footnotetext{
Lomas, Roman Italy.

Aug. Res gestae, 25 .
}

ves optimo iure, cioè dei cittadini romani con il diritto di voto. Così nascevano colonie che erano abitate sì da cittadini romani che però non avevano il diritto fondamentale di votare e quindi non potevano partecipare alle decisioni politiche dello stato romano.

La seconda forma di collaborazione con lo stato romano era la latinitas; chi otteneva il titolo di Latinus era un'abitante della penisola italica con alcuni diritti e doveri all'interno dello stato romano, come per es. la possibilità di commerciare e di contrarre matrimoni con cittadini romani e addirittura una forma limitata di collaborazione nella vita politica romana. A questo punto è necessario rilevare che entrambe le condizioni politiche (cioè Romanus, sia sine suffragio che optimo iure, come anche il Latinus) non dipendevano dall'appartenenza etnica degli abitanti o dalla loro origine genealogica: chiunque poteva diventare cittadino romano grazie ai meriti che otteneva o per altre vie? ${ }^{9}$ Massimo Cacciari sintetizza il senso della cittadinanza romana:

$$
\begin{aligned}
& \text { Civitas romana in quanto civitas augescens, città } \\
& \text { che esiste in virtù della sua capacità di incor- } \\
& \text { porare in sé nuove genti e nuovi territori, che } \\
& \text { neppure potrebbe sopravvivere se non ten- } \\
& \text { desse all’ imperium sine fine". Perciò quel- } \\
& \text { la di civitas aúescens ravoresenta l'idea chiave } \\
& \text { per comprendere lo stesso mito dell'impero } \\
& \text { universale. Poiché non è pianta che sorga da } \\
& \text { una terra e da un sangue, poiché, in questo } \\
& \text { senso, non ha radice, la civitas romana è desti- } \\
& \text { nata ab origine a crescere sempre. Nulla può } \\
& \text { "immobilizzarla”. Poiché la sua origine (po- } \\
& \text { tissima pars!) esclude ogni idea di "purez- } \\
& \text { za”, essa potrà comprendere in sé, assimi- } \\
& \text { lare-trasformare in sé, ogni popolo e ogni } \\
& \text { terra, essere Ecumene, essere Orbis, diventare } \\
& \text { per tutti Asylum. }
\end{aligned}
$$

Una terza forma di alleanza con lo stato romano erano i foederati, detti anche socii, cioè al-

\footnotetext{
9 Lomas, Roman Italy.

Io Massimo Cacciari, "Digressioni su impero e tre Rome", Micromega $5(2001): 43-63$.
} 
leati, con i quali i Romani suggellavano diversi trattati con vari diritti e doveri in base alla situazione dei singoli gruppi etnici. Valeva comunque la regola principale del "maiestatem populi Romani comiter conservare" (conservare unanime la forza del popolo romano), secondo la quale i soci collaboravano nelle guerre, ogniqualvolta si trattava della salvezza del popolo romano ${ }^{\mathrm{II}}$. Le varie popolazioni italiche erano nella maggior parte quindi foederati, ai quali erano stati concessi dei privilegi in cambio del loro servizio militare a favore dei Romani, come per esempio il conubium e il commercium. I Romani creavano con tutti i foederati soltanto alleanze bilaterali che non permettevano loro una politica esterna autonoma evitando così che si formassero alleanze anti-romane. Il compito principale degli alleati era di aiutare lo stato romano a difendersi in caso di attacchi, mentre le popolazioni erano del tutto autonome nelle questioni interne. Questo sistema offriva molti vantaggi allo stato romano, aveva infatti a disposizione un forte esercito e non investiva risorse finanziarie nell'amministrazione di tutto il territorio italico. Inoltre i Romani mantenevano il controllo politico su tutto il territorio, mentre alle popolazioni alleate non era permesso allearsi tra di loro. Il gruppo più ristretto e più elitario era certamente quello dei cittadini con tutti i diritti romani, ai quali seguivano un numero maggiore di cittadini sine suffragio.

Le possibilità di ottenere queste diverse forme di cittadinanza romana erano varie. Il modo più diffuso e comune era quello che Roma concedesse la cittadinanza ad un determinato gruppo di persone, etnico e politico. Le fonti antiche testimoniano che questo tipo di conferimento della cittadinanza era considerato da parte della comunità come una punizione, perché perdeva la propria autonomia e diventava quindi politicamente sottomessa a Roma ${ }^{\mathrm{I} 2}$. I Romani fondavano colonie con cittadini sine suffragio in quelle posizioni strategiche che permettevano loro di

\footnotetext{
I I Adrian Nicholas Sherwin.White, The Roman Citizenship (Oxford: Oxford University Press, 1939).

I2 Sherwin.White, The Roman Citizenship.
}

controllare meglio il territorio ${ }^{\mathrm{I}}$. D'altra parte le colonie latine erano invece più grandi e organizzate nei territori con un livello basso di urbanizzazione con lo scopo di sollecitare l'emigrazione della popolazione romana in queste terre. Già nell'anno 296 a. C. alcune popolazioni strinsero un patto di alleanza che insidiò gravemente Roma. Da allora in poi i Romani fondavano solo colonie con cittadini sine suffragio nell'Italia centrale formando così una fascia di territorio che correva attraverso tutta la penisola, dal mare Adriatico al mare Tirreno, dividendo così le popolazioni settentrionali da quelle meridionali e fermando ogni tentativo di alleanze tra le popolazioni italiche che appunto non avvenne fino all'anno 90 a. C.

\section{Il senso di appartenenza etnica delle popolazioni italiche prima e dopo} la guerra sociale

I trattati tra lo stato romano e le altre popolazioni della penisola italica permettevano da una parte a Roma di avere una forza militare cospicua, dall'altra invece portarono ad uno squilibrio politico tra gli alleati e lo stato romano. Le popolazioni italiche si rendevano conto della propria forza militare e chiedevano spesso di inserirsi attivamente nel processo politico dello stato romano richiedendone la cittadinanza.

Il problema dell'assegnazione della cittadinanza romana (civitas romana) ai socii era stato più volte oggetto di dibattito nel senato romano, ma non si arrivò mai ad un accordo comune. $\mathrm{Al}$ tempo dei fratelli Gracchi nell'anno I25 a. C. la questione fu di nuovo aperta dal console Marco Fulvio Flacco, ma il senato respinse la sua proposta. Alcuni anni più tardi il tribuno della plebe Livio Druso con l'aiuto degli alleati italici fece eleggere molte leggi a favore del popolo, agli alleati aveva invece promesso la legge sulla cittadinanza romana. Dalle Perioche di Tito Livio si evince che Livio Druso era stato a causa di questo odiato e considerato come l'iniziatore del-

13 Lomas, Roman Italy. 
la guerra sociale. ${ }^{\mathrm{I}}$ Quando il senato rifiutò per l'ennesima volta di conferire agli alleati la cittadinanza romana, il tribuno Livio Druso fu assassinato e nel 9r a. C. gli alleati si ribellarono provocando la guerra sociale (9I - 89 a. C.). Otto tribù italiche si allearono in una confederazione politica anti-romana, chiamata Italia con la capitale nella città di Corfino (al centro geografico della penisola) ribattezzata per l'occasione anch'essa in Italia, ovvero nella lingua degli Oschi in Viteliu. La confederazione coniò anche il proprio denaro, sul quale era raffigurato il toro italico che aggredisce e sbrana la lupa romana. I socii avevano quindi completamente abbandonato il progetto iniziale di diventare parte dello stato romano e si prefissero uno scopo contrario, cioè formare una nuova entità politica, lo stato italico. Gli ideatori del nuovo stato furono i Sanniti e i Marsi che erano nel contempo i più acerrimi nemici dell'espansione romana sulla penisola italica, gli Etruschi e gli Umbri invece decisero di non prendere parte alla confederazione italica ${ }^{\text {15 }}$.

All' inizio della sedizione i Romani subirono molte sconfitte, perché non avevano a disposizione quella forza bellica che prima l'offrivano gli alleati; potevano solo contare sull'aiuto dei Galli della Cisalpina e dei soldati che arrivavano da lontano. Dopo i successi ottenuti dagli Italici, si aggregarono a loro anche gli Etruschi e gli Umbri. L'anno successivo i Romani decisero di risolvere la questione con la Lex Iulia de civita$t e$, secondo la quale fu concessa la cittadinanza a quegli alleati che restarono fedeli a Roma, e poco dopo con la Lex Plautia Papiria dedicata a quelli che in sessanta giorni avrebbero abbandonato le armi e si sarebbero aggregati ai Romani, lo status di latinus fu invece attribuito agli abitanti della Gallia Cisalpina (Lex Pompeia de Transpadanis). Già queste leggi cambiarono l'assetto politico della penisola, nonostante la forza politica dei socii era rimasta limitata, dato che erano stati inseriti soltanto in otto tribù territoriali e non

\footnotetext{
I4 »Propter quae Livius Drusus invisus etiam senatui factus velut socialis belli auctor, incertum a quo domi occisus est.« (Livy, Per. $71,4)$.

I5 Rajko Bratož, Rimska zgodovina (Ljubljana: Študentska založba, 2007).
}

in tutte le trentacinque, quante ce n'erano nello stato romano. I conflitti si protrassero ancora per un anno nella zona dei Sanniti, ai quali venne in aiuto anche il re del Ponto Mitridate. Nell'anno 88 a. C. comunque tutte le ostilità terminarono $\mathrm{e}$ tutta la penisola divenne ager romanus.

La conclusione della guerra sociale con l'approvazione delle leggi però rappresenta "un punto di svolta, quando Roma decise di diventare da una città stato con comunità alleate legate con i trattati (in posizione legalmente inferiore) ad uno stato anche territorialmente allargato, nel quale tutti i liberi cittadini hanno una cittadinanza unitaria (...). Quelle comunità che prima erano formate dai Latini e dai socii, si sono estinte con l'introduzione di una cittadinanza romana uguale per tutti. L'assegnazione della cittadinanza romana agli abitanti di tutta l'Italia è diventata la base per la formazione di una coscienza italica e del senso di appartenenza alla comunità italica. Questi cambiamenti etnici si sono poi conclusi nel periodo del principato augusteo." $^{\text {'6 }}$

Molti ricercatori sono convinti nel pensare che con la guerra sociale il processo di romanizzazione delle popolazioni italiche abbia avuto un risvolto decisivo: il rapporto del popolo romano verso gli abitanti della penisola italica cambiò radicalmente: mentre prima della guerra il senato romano aveva perennemente rifiutato la cittadinanza agli Italici e non si preoccupava di aggregare tutte le popolazioni italiche in una tradizione culturale comune, dopo la guerra sociale i Romani cercavano assiduamente di introdurre sulla penisola italica un comune sentire italico affinché tutti gli abitanti si sentissero parte di una sola comunità, come se tutti avessero una tradizione comune e delle radici comuni, cosa che Augusto riuscì ad ottenere: "il latino era parlato dappertutto; non c'erano più Etruschi; non c'erano più Sanniti".

\footnotetext{
I6 Bratož, Rimska zgodovina.

17 Jorma Kaimio, "The ousting of Etruscan by Latin in Etruria" in Studies in the Romanization of Etruria, ed. Peter Brunn (Roma: Bardi Editore, 1975): $85-245$
} 


\section{I cambiamenti nell'autocoscienza etnica} delle popolazioni italiche prima e dopo la guera sociale

Parlare dell'appartenenza o dell'identità etnica vuol dire prendere in considerazione due punti di vista diversi: quella dei "vincitori", nel nostro caso i Romani, e il punto di vista delle popolazioni sottomesse, cioè quello degli altri abitanti italici. La maggior parte delle fonti ci descrive il punto di vista dei Romani, che risulta essere più chiaro, mentre invece più complesso è capire il senso di appartenenza etnica delle popolazioni italiche.

\section{Romani}

La percezione dei Romani è analizzabile attraverso le fonti degli storici latini e greci, la guerra civile fu infatti descritta dai storiografi greci, come Appiano (Bella civilia), Diodoro (rimasti solo alcuni frammenti) e Plutarco (Marius) e da quelli latini, come Tito Livio (su questo periodo ci sono rimaste solo le Perioche), Velleio Patercolo e più tardi anche Floro.

Per conoscere meglio il rapporto che i Romani avevano nei confronti degli Italici prima della guerra sociale è però necessario analizzare anche alcuni frammenti delle Origines di Catone, soprattutto dal secondo e terzo libro, nei quali lo scrittore latino si impegna a valorizzare le tradizioni degli italici. Catone infatti si prefigge lo scopo di sostenere quelle varianti della tradizione secondo le quali erano stati i Sabini il popolo originario della penisola italica, dai quali derivavano tutti gli altri popoli italici dell'Italia centrale. Rileva inoltre l'unità italica che si basa sui mores maiorum e sulle virtù come la fides, austeritas, virtus, quest'ultima concepita soprattutto come forza bellica.

Porro Lacedaemonios durissimos fuisse
omnis lectio docet, Sabinorum etiam m[ai]
ores populum Romanum secutum idem
Cato dicit: merito ergo $»$ severis $\ll$, qui et a
duris parentibus orti sunt et quorum dis- ciplinam victores Romani in multis secuti sunt. $^{\mathrm{I}}{ }^{8}$

Catone spiega che i Sabini erano duri, perché erano stati educati secondo severi principi educativi degli Spartani e continua con l'affermazione che proprio così come i Sabini, anche tutti i Romani devono essere coraggiosi e abili nella guerra come lo erano stati i loro antenati. I Sabini mantenevano la propria virtù integra e facevano attenzione a non essere troppo in contatto con altre popolazioni ${ }^{19}$. Come viene spiegato da Letta, lo scopo principale di Catone era di propagare l'origine italica delle città romane, perciò nella propria opera smentisce le sempre più diffuse leggende sull'origine greca delle città italiche e si avvicina invece di più alle origini italiche con lo scopo di avvalorare la forza delle popolazioni italiche come esempio di virtù per i Romani. Tutta l'opera di Catone è segnata da una forte ideologia italica che può essere percepita soprattutto nel secondo e terzo libro, nel quale Catone spiega l'origine e lo sviluppo delle singole tribù che avevano abitato o abitavano la penisola italica. Il rapporto di Catone verso gli Italici rimane comunque ambiguo; dal passo citato si può interpretare che Catone fosse stato convinto delle origini sabine dei Romani (a parentibus orti sunt). Purtroppo i rari frammenti non possono darci un quadro più dettagliato e chiaro del rapporto di Catone verso gli Italici. Potremmo dedurre che lo scrittore romano pensava ad un origine comune dei Romani o forse che i Romani fossero stati una mescolanza etnica tra gli Etruschi, i Sabini e i Latini, il che probabilmente era anche l'opinione più diffusa a Roma. Non possiamo però capire il rapporto di Catone verso gli altri popoli italici, che venivano invece considerati dei nemici dai Romani, come viene spiegato da Tito Livio nel suo racconto sulla guerra sociale. Lo storico romano appoggia la linea ufficiale

\footnotetext{
I 8 Fr. $93=\mathrm{ORF}_{3} \mathrm{I}_{2} 8$

19 Cesare Letta, "I legami tra i popoli italici nelle Origines di Catone: tra consapevolezza etnica e ideologia" in Patria gentibus diversis una? Unità politica e identità etniche nell' Italia antica, ed. G. Urso (Pisa, 2007): 171-195.
} 
della repubblica romana e descrive la guerra dal punto di vista dei vincitori.

\section{Complures populi ad hostes defecerunt. Cum P. Rutilius cos. parum prospere ad- versus Marsós pugnasset et in eo proelio cecidisset, C. Marius, legatus eius, meliore eventu cum hostibus acie conflixit. ${ }^{20}$}

Elencando i vari gruppi etnici, come per es. i Marsi che si sono aggregati ai nemici, Livio spiega che la guerra civile era una guerra contro un nemico esterno, poiché per gli Italici era usato il termine "hostes".

Tra le fonti del principato augusteo citiamo invece Strabone, che nel primo libro della sua storia ci trasmette la descrizione delle popolazioni italiche del suo tempo e un'interessante informazione:

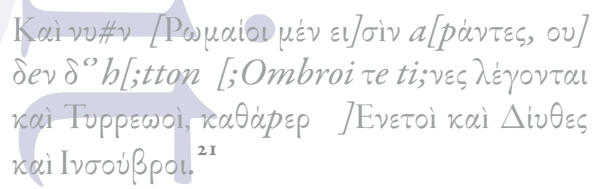

Le popolazioni italiche si chiamano tra di loro con i propri nomi, però nel contempo sentono l'appartenenza politica ad un stato soltanto e sono perciò cittadini dell'impero romano. Quindi ancora nel periodo del principato la loro identità resta ben definita, perché differiscono dal popolo romano mantenendo il loro nome il che è uno dei criteri principali per la definizione dell'identità di un gruppo etnico. Se quindi gli appartenenti alle singole popolazioni italiche si chiamavano tra di se ancora con il proprio nome, significa, che era ben radicato il loro senso di appartenenza al gruppo etnico e non invece al popolo romano. Strabone dimostra inoltre che ancora verso la fine del primo secolo a. C. le singole popolazioni mantenevano viva la propria autocoscienza e nonostante si siano inseriti nello stato romano, si identificavano ancora col proprio gruppo etnico.

La stessa problematica viene trattata anche da Cicerone nel De legibus, quando afferma che

\footnotetext{
20 Livy, Epit. 73.3-4. Livio usa lo stesso termine $\gg$ hostes $\ll$ anche in altri passi: Livy, Per., 73, 6; 75, 4, 6 .

2 I Strabo, I, io.
}

ogni cittadino romano ha due patrie: la prima è quella, dove ogni cittadine era nato, la seconda quella che lo ha adottato:

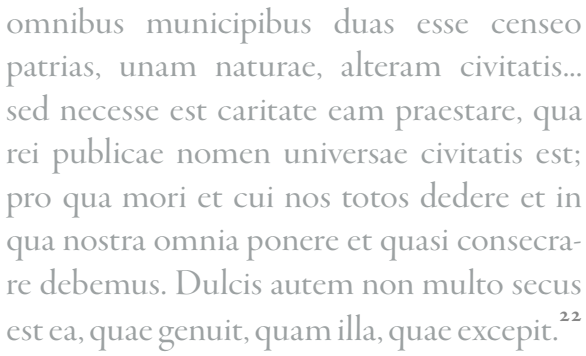

Entrambe le patrie sono certamente molto vicine al cuore di ognuno, ma il retore romano aggiunge che secondo lui bisognerebbe dare la precedenza a quella più ampia. Anche il senso di appartenenza al territorio rientra infatti tra i criteri per la definizione del gruppo etnico: $\mathrm{Ci}$ cerone nel proprio lavoro richiama l'attenzione al dilemma dei cittadini romani, abitanti delle province italiche che sentivano una lacerazione interna tra la propria patria e lo stato romano: sentivano infatti una forte connessione con le proprie radici, ma facevano già parte della nuova patria.

Anche per gli scrittori latini dell'età imperiale la guerra sociale e le popolazioni italiche rappresentano un interessante tema, descrivendolo però da un punto di vista diverso. Velleio Patercolo, storico dell'epoca augustea, elenca la causa della nascita della guerra sociale come una risposta lecita alla repressione di quella gente che difendeva lo stato con le proprie armi e che offrivano un numero doppio di soldati e cavalieri; lo storico romano giustifica il fatto avvenuto come la ribellione di una parte della popolazione che però faceva parte dello stesso popolo e addirittura della stessa gente:

quorum ut fortuna atrox, ita causa fuit ius tissima; petebant enim eam civitatem cuius imperium armis tuebantur; per omnes annos atque omnia bella duplici numero se militum equitumque fungi neque in eius civitatis ius recipi quae per eos in id ipsum pervenisset fastigatum ex quo eiusdem et 22 Cic. Leg. 2, 2, 5 
gentis et sanguinis ut externos alienosque fastidire posset. ${ }^{23}$

Patercolo usando il termine "sanguinis" fa capire che le popolazioni italiche erano secondo lui imparentate tra di loro, il che però non è una condizione essenziale dell'appartenenza allo stesso gruppo etnico. Lo storico vuole però sottolineare degli stretti legami genealogici tra il popolo romano e quelli italici con due termini, "gens" e "sanguis", che erano considerati come dei criteri essenziali per l'appartenenza ad un unico gruppo etnico. Una testimonianza molto simile viene fornita da Floro, scrittore del secondo secolo dopo C.:

\section{Quippe cum populus Romanus Etruscos, \\ Latinos, Sabinosque sibi miscuerit et unum ex omnibus sanguinem ducat, corpus fecit ex membris et ex omnibus unus est. ${ }^{24}$}

Floro con la metafora di un unico corpo con più membra rappresenta chiaramente il rapporto tra i Romani e gli Italici, e pone l'accento, che tutti erano originari da un unico sangue "unum ex omnibus sanguinem".

Un'altra fonte della guerra sociale è Appiano, che nel suo primo libro della storia romana spiega le cause della guerra sociale; prima di elencarle, racconta il lavoro politico di Gaio Gracco rilevando il suo impegno nell'inserire i Latini nell'amministrazione della repubblica:

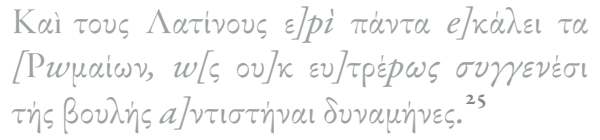

Anche Appiano mette in risalto i legami di sangue tra i Latini e i Romani usando il termine $\sigma \nu \gamma \varepsilon \nu \dot{\varepsilon} \sigma \mathrm{l}$, quindi la stessa origine genealogica, cioè appartenenti alla stessa stirpe. Quando invece parla delle popolazioni italiche, usa il termine

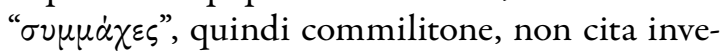
ce nessun legame parentale e nessun collegamento tribale tra di loro. Soltanto quando comincia a raccontare della guerra sociale, la chiama addi-

23 Vell. Pat., 2. 15. 2.

24 Flor., 2,6,1.

25 App.Sam. I, 99 . rittura "guerra civile" - $\varepsilon] \mu \phi \dot{\lambda} \lambda ı \nu$ pó $\lambda \varepsilon \mu o \nu$ (App. Sam. I, I78), una guerra fratricida quindi all'interno della stessa popolazione.

Analizzando quindi la descrizione della guerra sociale tra gli storici romani e greci nell'arco di un po' più di un secolo si può notare uno spostamento e una diversa visione dei fatti proprio riguardo al concetto d'identità etnica sia del popolo romano, ma soprattutto delle popolazioni italiche. Tito Livio considerava gli Italici come dei "nemici" e degli "stranieri". Velleio Patercolo che era un po' più giovane di Livio e più tardi anche Floro credono invece che le popolazioni italiche fossero appartenenti allo stesso gruppo etnico e alla stesso stirpe genealogica. Floro all'inizio parla ancora di Sabini, Latini e Romani, che dopo si sono congiunti in un unico corpo "unum ex omnibus sanguine". Velleio Patercolo invece con la definizione precisa "eiusdem et gentis et sanguinis" dimostra la percezione che tutti gli Italici erano appartenenti alla stessa popolazione e alla stessa stirpe. Dello stesso parere era anche lo storico greco Appiano che chiama la guerra sociale addirittura "guerra civile”, quindi una battaglia tra appartenenti allo stesso stato e alla stessa popolazione, il che indica che la percezione delle popolazioni italiche si è trasformata radicalmente nel giro di qualche decennio; il passo più grande è stato fatto nell'età augustea come si è potuto vedere dai pensieri di Cicerone e Livio che considerano gli Italici ancora come nemici.

\section{Il punto di vista delle popolazioni indigene}

Il rapporto dei Romani vincenti nei confronti degli Italici è quindi chiaro; molto più complesso è invece capire che cosa pensavano gli Italici di se stessi. La problematica dell'autocoscienza delle singole popolazioni è molto articolata, dato che si parla dıi un livello psicologico che è difficilmente percepibile a distanza di tanti secoli; ci rimane quindi soltanto l'analisi delle singole forme e criteri che definiscono l'appartenenza ad un gruppo etnico, cioè il modo in cui le singole popolazioni sentivano la propria identità. Lana- 
lisi è maggiormente ostacolata dalle scarse fonti che potrebbero fornirci qualche informazione in più sulla coscienza della propria identità. Ci manca soprattutto una tradizione letteraria originale che potrebbe direttamente offrire uno squarcio dei pensieri sulla vita e sull'identità di queste popolazioni. Ci rimangono comunque alcune testimonianze indirette dagli scrittori greci e latini, alcuni documenti epigrafici, soprattutto per il popolo degli Etruschi.

Tra i criteri di appartenenza ad un gruppo etnico rientra l'uso della lingua. Fino alla fine del $3^{\circ}$ secolo a. C. il latino è diventato la lingua di comunicazione anche nelle più piccole comunità e tribù della repubblica. In breve tempo svanì la lingua dei Volsci, nelle iscrizioni osche invece si possono notare molte interferenze con il latino. Con la graduale espansione dello stato romano anche la lingua latina ebbe la sua larga espansione, ma nonostante ciò non fu possibile estirpare così velocemente tutti gli idiomi locali. La buona conoscenza del latino è dimostrata anche dal fatto che molti autori latini, nati fuori Roma, conoscevano e usavano perfettamente il latino come lingua letteraria illustre. Nel secondo secolo a. C. il latino è diventato la lingua del commercio e di comunicazione tra diverse tribù italiche, ma "le parlate autoctone mostravano ancora la propria vitalità nonostante l'uso sempre più frequente del latino. (...) Qualcuno potrebbe supporre che le popolazioni e le tribù nel secondo secolo a. C. si rendevano conto della propria diversità che li distingueva dai Romani. Il loro innato e illimitato amore per l'autonomia era la causa principale delle loro reazioni ai fatti esteri., ${ }^{26}$ All'epoca della fioritura della repubblica romana esisteva quindi ancora una certa differenziazione tra il popolo romano e le restanti popolazioni italiche, il che lo dimostra l'uso assiduo della propria lingua e scrittura. Nel primo secolo a. C. il problema stava diventando sempre più sentito, i Romani insistevano sulla differenziazione per distinguersi dagli Italici sia culturalmente sia politicamente, mantenendo soprattutto i privilegi

26 Edward Togo Salmon, The Making of Roman Italy (London: Cornell University Press, 1985). che non erano concessi alle popolazioni italiche. Chiaro è che ai tempi della repubblica i Romani non avevano nessuna intenzione di assimilare gli Italici, anche la latinizzazione delle parlate locali della penisola era di minore interesse; soltanto a livello locale era permesso l'uso della lingua indigena nelle faccende che riguardavano il municipium stesso. Un esempio di questi cambiamenti è fornito da Livio, secondo il quale la città di Cuma raccolse una petizione richiedendo fosse usato il latino come lingua ufficiale del municipium; questo diritto gli è stato poi concesso da parte del senato romano. ${ }^{27}$ Quest'esempio ci dimostra che nelle pratiche comuni della città veniva usata la parlata locale e non il latino. Gli storici romani comunque non approfondiscono la questione della politica linguistica romana, il che ci dimostra che il problema neanche si poneva. Erano soltanto interessati al fatto che il latino diventasse la lingua di comunicazione e nel contempo non si prefiggevano lo scopo di estirpare le parlate locali. D'altra parte la conoscenza della lingua latina era utile agli abitanti della penisola italica perché potevano così ottenere privilegi, commerciare e mantenere i contatti con il mondo esterno. Kaimio del resto mette in risalto il fatto che i Romani non avevano nessun interesse ad allargare la propria lingua e cultura, perché così facendo avrebbero dato una ragione e una possibilità in più agli italici di aggregarsi contro di loro, mentre nel loro interesse era mantenere la dispersività delle tribù italiche. In sostanza fino alla guerra sociale i Romani volevano mantenersi ben lontani dalle popolazioni italiche e accentuavano la loro diversità sia culturale che linguistica e collegata a questa anche quella etnica.

Dopo la guerra sociale invece le cose cambiarono: gli abitanti della penisola italica divennero sul piano politico cittadini romani, e anche la diffusione del latino divenne più marcata; le lingue come quella etrusca, messapica, sabina cominciavano ad estinguersi. La latinizzazione della penisola italica è collegata anche alla conquista politica dei territori ed è ovviamente più

27 》Cumanis eo anno petentibus permissum, ut publice Latine loquerentur $\ll$ (Livy, Per. 40.42.13) 
forte e avanzata in quei territori che erano più vicini a Roma; un ruolo importante era svolto dalle infrastrutture, come le strade, le città, le colonie ecc. e proprio perciò è chiaro perché le città più vicine al mare si svilupparono presto in centri multiculturali, mentre invece quelle all'interno rimanevano nella mani delle popolazioni italiche. Kaimio del resto individua che alcune scritte in certe lingue italiche si sono mantenute a lungo anche dopo la conquista romana del territorio, e come esempio cita soprattutto le scritte messapiche al sud dell'Italia: la lingua messapica infatti rimase lingua di comunicazione fino alla fine della repubblica ${ }^{28}$.

Diversa era invece la situazione della lingua greca che si mantenne a lungo nella parte meridionale della penisola addirittura a tal punto che ancora oggi esistono comunità greche sulla penisola italica. Le cause di questa vitalità della lingua sono molto chiare: le colonie greche avevano mantenuto da sempre un rapporto molto stretto con le proprie metropoli che offrivano alle colonie un sostegno continuo e anche un supporto culturale assiduo. La lingua greca manteneva un alto livello di prestigio sociale in tutta l'area mediterranea dato che era diventata il modello culturale. Il privilegio sociale del greco non è quindi comparabile a quello delle altre lingue italiche.

Mentre quindi il latino si stava espandendo sempre di più, le lingue italiche erano in estinzione, fatto che può dimostrare anche un basso livello di autocoscienza etnica delle popolazioni italiche. La causa di un declino così veloce delle parlate locali può essere attribuito a diversi fattori, tra i quali vanno elencati soprattutto un basso livello di istruzione, la mancanza di un sistema scolastico che avrebbe potuto trasferire tradizioni, cultura, lingua e conoscenze e con questo anche un'identità etnica alle generazioni più giovani. Questi fattori erano al contrario molto ben presenti nelle colonie greche che mantenevano viva la propria lingua e le curavano ${ }^{29}$.

\footnotetext{
28 Oronzo Parlangeri, Studi messapici (Milano: Istituto Lonbardo di scienze e lettere, 1960).

29 Livy, Per., 24.3.1 i; Vell. Pat. I.4.2.
}

Le confederazioni politiche che nascevano tra le varie popolazioni erano soltanto alleanze con lo scopo principale di una ribellione anti-romana. Queste confederazioni si costituivano di solito in base a un denominatore comune che però era ogni volta diverso: a volte si aggregavano popolazioni sul principio delle loro credenze religiose, altre della volontà politica; queste confederazioni non nacquero però mai su un principio etnico, in base al quale le tribù avrebbero potuto aggregarsi, perciò non si formò neanche mai un'entità politica su base etnica. La mancanza di questo elemento comune ha portato anche al fatto che le fondamenta, sulle quali nacquero queste confederazioni, si sgretolarono presto, dato che le popolazioni non avevano una credenza comune, dei miti, leggende, cultura e religione comuni, il che avrebbe potuto aumentare il loro senso di appartenenza ad un gruppo. Ciò non significa che le tribù italiche erano assolutamente indifferenti alle proprie credenze cioè alla propria identità; molte popolazioni avevano la propria memoria storica e i propri miti sulle loro origini il che manteneva viva anche la loro identità. Ma questa identità era evidentemente troppo debole per potersi mantenere nel tempo.

\section{Il senso di appartenenza degli Etruschi e dei Sanniti}

Cercheremo adesso di definire l'identità etnica nel caso di due popolazioni italiche che risposero diversamente alle conquiste romane sulla penisola italica. Saranno presi in esame da una parte gli Etruschi che raggiungevano secondo le fonti antiche un alto grado di acculturazione, e i Sanniti, che rappresentano invece l'antitesi degli Etruschi sul piano culturale, mentre invece a livello militare erano molto efficaci e riuscirono a lungo a opporsi all'espansone romana. Il rapporto che i Romani avevano nei confronti di entrambe le popolazioni mostra una viva ambivalenza, poiché rispondevano diversamente alle sommosse degli uni e degli altri. L'esame delle due popolazioni prenderà in considerazione soprattutto la loro autocoscienza etnica. 
Luciana Aigner Foresti ha cercato, in base a diverse fonti storiche, epigrafiche e letterarie, di capire il grado di autocoscienza degli Etruschi analizzando i vari vincoli culturali, politici e religiosi che portarono gli Etruschi ad una omogeneità culturale e coscienza di se stessi come di una popolazione autonoma che si rendeva conto della propria specificità e si differenziava dagli altri $^{3 \circ}$. Sul piano politico ci sono stati diversi tentativi, dai quali si può evincere il desiderio degli Etruschi di raggruppamento all'interno del popolo stesso. Oltre alle varie iscrizioni e fonti storiche che mettono in risalto il fatto che gli Etruschi chiamavano tutti se stessi Rasna ${ }^{31}$, bisogna sottolineare l'aggregazione politica delle dodici città etrusche che spesso intervenne nel confronti dei Romani come un'unità politica autonoma e omogenea. Esistono tra gli storici ancora posizioni diverse riguardo a questa unità politica delle dodici città etrusche: molti non sono convinti che in realtà esistesse davvero, sottolineando che l'ordinamento politico degli Etruschi era simile a quello greco delle città-stato e che in realtà questa confederazione non fosse in realtà mai esistita.

Tra i fattori che determinano un gruppo etnico c'è anche la memoria storica che era per gli Etruschi veramente molto ben definita, dato che conosciamo la divisione della storia etrusca in dieci saecula ${ }^{32}$. Ci sono rimasti anche alcuni frammenti delle Tuscae Historiae nei testi dello scrittore romano Censorino che ci dimostrano una viva coscienza della propria memoria storica comune degli Etruschi e che del resto viene anche sottolineata negli affreschi delle tombe sul mito di Rasenna, sul re Mastarna o su fratelli Vipina. Anche gli scrittori romani sono convinti che gli Etruschi avessero cura dei propri alberi genealogici ${ }^{33}$. Quando gli Etruschi parlavano della propria storia, si parlava sempre di Rassena,

30 Lucia Aigner Foresti, "Gli Etruschi e la loro autocoscienza" in $A u$ tocoscienza e rappresentazione dei popoli nell' antichita, ur. Marta Sordi (Milano: Vita e pensiero, 1992), 93-113.

$31 \quad$ Dion. Al. I.30.3

32 Marta Sordi, "I saecula degli Etruschi e gli ostenta" Rivista storica italiana $\mathrm{II}_{4}$, no. 3 (2002), $715-725$.

33 Pers. 3.27; Orazio su Mecenate. probabilmente però consideravano se stessi come un popolo autoctono, come scrive Dionisio D'Alicarnasso, che "pur dedicando grande spazio al problema dell'origine degli Etruschi, non si sofferma a raccontarci esplicitamente cosa gli Etruschi stessi pensavano sulla loro origine, anche se è probabile che se fossero stati di parere diverso dal suo, ce lo avrebbe detto e lo avrebbe discusso $\ll{ }^{34}$ Secondo il parere di Dioniso quindi gli Etruschi sarebbero stati una popolazione autoctona con le proprie origini nell'eroe Rassena. Tra i fattori principali della coscienza degli Etruschi la Foresti elenca anche il fatto che più tardi Augusto aggregò tutte le città etrusche in un'unica regione, la VIIa regio, Strabone invece ci testimonia che la definizione terminologica per gli Etruschi Tuppìvol veniva usata ancora nel I ${ }^{\circ}$ secolo dopo C. ${ }^{35}$

Il fattore identificativo più importante per la dimostrazione di una forte coscienza etnica degli Etruschi è proprio la loro dimensione religiosa. Propria la religione è quel settore per il quale gli Etruschi erano anche molto conosciuti: i loro dei, le credenze, incontri al Fanum Voltumnae, dove i rappresentanti di varie città etrusche sacrificavano insieme agli dei o anche molto famosa era la loro aruspicina, cioè l'arte di predire il futuro interpretando i segni della natura. L'insieme di tutti questi fattori ci dimostra un forte senso di appartenenza alla comunità religiosa etrusca.

Attraverso queste testimonianze gli Etruschi svilupparono anche la loro memoria storica e consolidarono le proprie tradizioni culturali e politiche, il che ci indica che il loro senso d'identità etnica era la conseguenza di una scelta volontaria e quindi aprioristicamente era molto forte $\mathrm{e}$ ancorato. Questo viene confermato dal loro desiderio di mantenere vive le proprie tradizioni il che è uno dei fattori più importanti per l'identificazione etnica. I resti archeologici dimostrano nel contempo anche un forte sviluppo artistico che era impregnato sì anche di cultura greca, ma che manteneva alcune caratteristiche che gli

34 Foresti, "Gli Etruschi e la loro autocoscienza", 93-I I3.

35 Strabo, I, IO 
davano una patina identificativa particolare. Oltre a tutto ciò bisogna anche aggiungere che gli Etruschi avessero mantenuto la loro lingua e la loro scrittura ancora a lungo come lo testimoniano le iscrizioni.

Soltanto nel primo secolo dopo C. la scrittura e la lingua etrusca stavano cominciando ad estinguersi e prendevano posto la lingua e la scrittura latina. Come menzionato all'inizio la lingua non è l'unico criterio di identificazione di un gruppo etnico, è però anche vero che è un fattore importante e in molti casi è proprio la lingua quella che accomuna gli appartenenti ad un unico gruppo etnico e mantiene la loro identità. Se gli Etruschi sono quindi considerati anche una comunità linguistica, nel loro caso fu proprio la lingua, il primo fattore che venne trascurato. La storica Marta Sordi ha a lungo studiato la storia etrusca arrivando alle conclusioni che gli Etruschi si rendevano conto della propria fine e questo sia dal punto di vista politico che anche culturale ed etnico, poiché si stavano per terminare i famosi dieci saecula che erano previsti per la loro storia; perciò hanno cominciato di proprio conto a tradurre i propri testi in latino con lo scopo di mantenere vivo il ricordo degli Etruschi, le loro tradizioni, la loro religione soprattutto all' interno dello stato romano ${ }^{36}$. Brunn ci fa sapere invece che se gli Etruschi tralasciarono la propria lingua relativamente presto, mantennero invece a lungo le proprie tradizioni sepolcrali e non si assimilarono alle tradizioni romane ${ }^{37}$. Tra tutte le popolazioni italiche furono infatti proprio gli Etruschi quelli che si distinguevano di più dai Romani, erano culturalmente coscienti, avevano la propria lingua e scrittura, la propria religione e le proprie tradizioni, erano però i pri$\mathrm{mi}$ ad accorgersi che avrebbero dovuto abbandonare la propria lingua e il proprio nome. La Sordi aggiunge che erano anche gli unici che però dall'altra parte mantennero anche all'epoca del tardo impero i propri culti religiosi e influirono parecchio sulla concezione religiosa dei Romani.

36 Marta Sordi, "Il paradosso etrusco: il "diverso" nelle radici profonde di Roma e dell' Italia romana" in Patria gentibus diversis una? Unità politica e identita etniche nell' Italia antica, ed. G. Urso (Pisa, 2007), 89-97.

37 Brunn, Studies in the Romanization of Etruria.
Nella cultura romana hanno portato la propria arte dell'aruspicina che i Romani mantenevano viva ancora per molti secoli dopo che il nome degli Etruschi era già scomparso.

Le conclusioni quindi ci portano a credere che gli aristocratici Etruschi avessero una forte coscienza di se stessi e della propria appartenenza ad una comunità etnica autonoma che aveva anche delle connotazioni politiche, artistiche, culturali e religiose. Un tale sviluppo ha permesso che la classe d'elite avesse sviluppato un senso di superiorità sulle altre popolazioni italiche e poteva perciò anche controllarli. Questo lo testimonia anche Catone, quando dice che probabilmente tutta l'Italia era sottomessa agli Etruschi. ${ }^{38}$ Nonostante un'autocoscienza così sviluppata però non potevano fermare il processo di romanizzazione che avrebbe comunque portato gli Etruschi ad abbandonare la propria lingua e anche il proprio nome, anche se, grazie alla loro lungimiranza ebbero la possibilità di arricchire con le proprie tradizioni e sapere la cultura romana.

Per una diversa strategia di opposizione allo stato romano invece optò la popolazione sannitica che viene descritta da Livio:

\section{Bello non abstinebant: adeo ne infeliciter quidem defensae libertatis taedebat et vinci quam non temptare victoriam malebant. ${ }^{39}$}

Dalla storia di Livio e da altre fonti possiamo capire che i Sanniti erano uno dei popoli più belligeranti, contro i quali i Romani avevano combattuto. Per loro la libertà politica era il valore più alto, per la quale volevano combattere fino all'ultimo. Da questo potremmo dedurne che anche la loro autocoscienza era alta. I Sanniti erano anche i primi a chiamare la penisola italica "Italia" per aggregare tutte le popolazioni italiche nella guerra contro Roma.

Sui Sanniti non ci sono molte fonti, i resti della loro cultura sono scarsi, sia sul piano archeologico che su quello storico non disponiamo di molte informazioni, perciò capire il loro livello

»quia in Tuscorum iure paene omnis Italia fuerat « (Cato, Orig. 2.67)

Livy Epit. 10. 31.14 
di autocoscienza è più difficile. Intanto si pone già subito all'inizio la domanda se i Sanniti si consideravano come una popolazione unitaria o erano soltanto un insieme di varie tribù in parte sviluppate culturalmente. Riguardo al loro livello di autocoscienza cercheremo di analizzarlo sulla base della loro organizzazione politica, culturale e religiosa.

I Sanniti non conoscevano l'organizzazione politica in municipia come i Romani e non conoscevano neanche le città-stato dei Greci e degli Etruschi. La loro unità politica erano i touto, cioè comunità di abitanti, ai quali presiedevano $i$ sacrati - sacerdoti. Non possiamo quindi parlare di un'unica unità politica, ma al massimo di una confederazione di touti. I tentativi di organizzazione delle tribù sannitiche si basavano sulla forma "pagano-vicana", dato che l'unità principale era il pagus, cioè il villaggio come il centro abitativo dei Sanniti, l'organizzazione urbana invece non era presente dai Sanniti. Questa popolazione venne in contatto con la politica espansionistica di Roma nel quarto e terzo secolo a. C., ma i Sanniti si opponevano molto efficacemente ai Romani, aggregandosi agli Oschi e fondando la lega sannitica. Si trattava di una forte lega militare e politica che aveva anche un fattore religioso, ma lo scopo principale rimaneva comunque la politica antiromana. I Romani non riuscirono a trovare appoggio in questo caso nei ceti aristocratici dei Sanniti, come per esempio sono riusciti a farlo con i Campani, gli Apuli e i Liguri, perciò si è arrivati alle guerre sannitiche. Più tardi la lega sannitica si congiunse anche con il re Pirro, mentre durante l'assedio di Annibale alla fine del terzo secolo non si trovano più tracce della lega.

Riguardo all'aspetto religioso le tribù sannitiche non avevano una dimensione religiosa comune. Le divinità principali erano quelle uguali alle altre popolazioni italiche, tra le quali si cita soprattutto il Ver sacrum, durante il quale si sacrificava bestie e oggetti alle divinità. Questo rito rappresentava un rito comune a tutte le comunità italiche, ma soltanto i Sanniti lo prefiggevano regolarmente sul proprio territorio. Per i
Sanniti era infatti tipica la polilatria, cioè la venerazioni di più divinità sullo stesso luogo. L'iscrizione di Anona nella lingua osca testimonia che in quel luogo erano venerati 17 divinità.

La lingua dei Sanniti, chiamata lingua osca dalle popolazioni che abitavano questi territori prima, mostra un alto livello di sviluppo: le iscrizioni infatti mostrano che si basava su rigide e ben definite regole grammaticali. Era diffuso in tutta la penisola italica ed era usato da tutte le popolazioni della Sicilia settentrionale, dai Lucani e Mamertini fino agli Umbri. Le regole grammaticali sono molto simili a quelle latine, solo a livello fonologico, morfologico e ortografico sono evidenti delle chiare differenze. I Sanniti avevano anche una tradizione letteraria come viene testimoniato da Livio, purtroppo però nulla è rimasto. In sostanza, dai dati che ci sono noti, non possiamo parlare di un alto grado di autocoscienza tra i Sanniti, almeno non così come dagli Etruschi. Avevano sì una vita politica organizzata, rappresentata da una forma di confederazione politica di diverse tribù; sul piano religioso non ci è possibile ricostruire qualche elemento identificativo che li distinguerebbe dalle altre popolazioni italiche. Avevano sì la propria lingua e la propria tradizione letteraria, ma ne uno ne l'altro non può essere un fattore definitivo per avvalorare una sviluppata coscienza etnica. Rimane comunque da capire perché erano stati proprio i Sanniti a opporsi il più a lungo ai Romani, come lo si può capire dalle fonti storiche. A differenza degli Etruschi che si sono sottomessi alla pressione politica romana e l'hanno accettato cercando di inserirsi il più produttivamente possibile nel processo politico romano, i Sanniti dall'altra parte invece si sono opposti assiduamente a ciò. Le guerre sannitiche che si svolgevano ancora nel quarto e terzo secolo a. C. sono la prova di un aspro conflitto tra due antagonisti equivalenti, che si consideravano l'un l'altro dei "hostes". Questo fattore storico convalida la supposizione che un gruppo etnico comincia a prendere coscienza di se o fortifica la propria autocoscienza quando arriva un nemico esterno. Questo è successo probabilmente per i Sanniti che fino all'ar- 
rivo dei Romani erano stati soltanto una confederazione di villaggi, non una popolazione che aveva coscienza di se. Quando invece arrivò un nemico comune, si fondò la lega sannitica, basata non su interessi politici, religiosi e culturali, ma su quelli anti-romani. I Sanniti quindi probabilmente avevano un basso livello di autocoscienza, e non si sentivano appartenenti alla stessa comunità etnica.

\section{Conclusione}

Dall'analisi di questi due casi si può capire che il $\stackrel{m}{m} \quad$ livello di autocoscienza dei singoli popoli italici era molto diverso e divergente: mentre gli Etruschi avevano un alto livello di autocoscienza e un livello sviluppato di appartenenza al proprio gruppo etnico, i Sanniti non avevano una situazione così sviluppata. Allo stesso modo anche la tradizione culturale delle popolazioni italiche non poteva opporsi alla romanizzazione culturale e anche una debole coscienza etnica non poteva mantenere la loro autonomia. Prendendo in considerazione tutti questi fattori il senato romano riuscì relativamente presto a risolvere il problema dei socii: subito quando fu offerta agli Italici la cittadinanza romana, tutti gli sforzi di fondare uno stato italico svanirono. Da allora in poi l'atteggiamento dei Romani nei confronti degli Italici cambiò, non erano più visti come "externi" o "nemici", ma si cercavano invece le radici comuni e gli Italici diventarono addirittura consanguinei. A causa di una debole autocoscienza degli italici il processo di romanizzazione a livello culturale fu abbastanza veloce, poiché nel giro di qualche decennio le popolazioni italiche abbandonarono il proprio nome, la propria lingua e scrittura. Cambiò appunto anche l'atteggiamento dei Romani nei confronti degli italici, fatto dovuto però anche alla forte propaganda augustea per formare un'unità culturale e politica unitaria, cioè l'Italia.

\section{Povzetek}

V obdobju med zavezniško vojno (9I - 88 pr. Kr.) je prišlo do pomembnih sprememb pri vprašanju etnične pripadnosti italskih ljudstev. Avgustov politični program je stremel za poenotenjem celotnega italskega polotoka $\mathrm{v}$ eno samo politično, kulturno in etnično enoto, kar pa še v času zavezniške vojne ni bilo tako samoumevno. Primera Etruščanov in Samnitov jasno prikazujeta razlikev nivoju samopodobe in etnične zavesti različnih ljudstev v Italiji: medtem ko so imeli prvi visoko razvito kulturo in posledično tudi zavest o lastni etnični pripadnosti, Samniti in številna druga ljudstva tega niso imela, zato pa so se lažje vključevala v rimsko državo. V trenutku, ko je Rim predlagal državljanstvo vsem italskim ljudstvom, se je tudi odnos do teh ljudstev spremenil: niso bili več »externi $\ll$ ali $\gg$ nasprotniki $\ll$, temveč so v zgodovinskih in mitografskih zgodbah iskali skupne bratske korenine. Italska ljudstva so se sicer odrekla svojemu imenu, navadam, kulturi in tradicijam, nekatera od teh (predvsem Etruščani) pa so rimski kulturi zapustila svoje navade. Cesarju Avgustu je tako s svojim političnim programom uspelo ustvariti kulturno enoto po geslu: »Iuravit in mea verba tota Italia sponte sua ${ }^{40}$

\section{Summary}

In the period between the Allied War (9I-88 BC) there were important changes in the ethnic question of Italian peoples. The Augustan political program sought to unify the entire Italian peninsula into a single political, cultural and ethnic unit, which, however, was not a self-evident before and during the Allied War. The examples of Etruscans and Samnites clearly show the differences in the level of self-image and ethnic awareness of different peoples in Italy: while the first had highly developed culture and, consequently, the awareness of their own ethnic affiliation, the Samnites and many other peoples did not have it and therefore, were easily subjected to the Roman state. At the moment when Rome proposed citizenship to all the Italians, the attitudes to there peoples was also changed: they were no longer "externa" or "opponents", but in the historical and mythographic stories they sought common fraternal roots. The Italian people have renounced their name, habits, culture and traditions, while some of them (especially Etruscans) have abandoned their habits to Roman culture.Thus, with his political program, Emperor Augustus managed to create a cultural unit after the motto from his Res gestae: "Iuravit in mea verba tota Italia sponte sua".

$40 \quad$ Aug. Res gestae, 25 . 


\section{Bibliografia}

Aigner Foresti, Lucia. "Gli Etruschi e la loro autocoscienza” in Autocoscienza e rappresentazione dei popoli nell'antichità, ed. Marta Sordi, 93-I13. Milano: Vita e pensiero, 1992.

Aigner-Foresti, Lucia. "Quod discinctus eras, animo quoque, carpitur unum « (Maec., El. I.2I)", Contributi dell'Istituto di Storia Antica 17 (1991): 20I-214.

Bandelli, Gino. "La politica romana nell'Adriatico orientale in età repubblicana", in Seminario storicoarcheologico su "L'arco adriatico in etḋ romana e altomedievale”, I68-2I4. Trieste, 1986.

Bratož, Rajko. Rimska zgodovina. Ljubljana: Študentska založba, 2007.

Cacciari, Massimo. "Digressioni su impero e tre Rome". Micromega 5 (200I): 43-63.

Clemente, Guido. Guida alla storia romana. Milano: Mondadori, 200I.

Farney, Gary D. Ethnic identity and aristocratic Competition in Republican Rome.

Cambridge: Cambridge University Press, 2007.

Gruen, Erich. Culture and National Identity in Republican Roma. New York: Ithaca, 1984.

Hall, Jonatan M. Ethnic Identity in Greek Antiquity. Cambridge: Cambridge Core, 1997.

Kaimio, Jorma. "The ousting of Etruscan by Latin in Etruria" in Studies in the Romanization of Etruria, ed. Peter Brunn, 85-2 45. Roma: Bardi Editore, 1975.

Letta, Cesare. "I legami tra i popoli italici nelle Origines di Catone: tra consapevolezza etnica e ideologia" in Patria diversis gentibus una? Unità politica e identità etniche nell'Italia antica, ed. G. Urso I7 I195. Pisa, 2007.

Lomas, Kathryn. Roman Italy: 338 BC - AD 200. London: Ruotledge, 1996.

Noel, Donald L. "A Theory of the Origin of Ethnic Stratification”. Social problems 16, no. 2 (I968): 28-34.
Parlangeri, Oronzo. Studi messapici. Milano: Istituto Lombardo di scienze e lettere, I960.

Salmon, Edward Togo. The Making of Roman Italy. London: Cornell University Press, 1985.

Sherwin White, Adrian Nicholas. The Roman Citizenship. Oxford: Oxford University Press, 1939.

Smith, Anthony D. The Ethnic Origins of Nations. Oxford: Blackwell Publishers, 1986.

Sordi, Marta. "I saecula degli Etruschi e gli ostenta”. Rivista storica italiana II 4, no. 3 (2002), 715-725.

Sordi, Marta. "Il paradosso etrusco: il "diverso" nelle radici profonde di Roma e dell'Italia romana" in Patria diversis gentibus una? Unità politica e identità etniche nell'Italia antica, ed. G. Urso, 89-97. Pisa, 2007.

Syed, Yasmin. Vergil's Aeneid and the Roman Self. Ann Arbor: The University of Michigan Press, 2005.

Toll, Kathrin. "Making Roman-ness and the Aeneid”. Classical Antiquity 16 (1997): 3456. 
-

r

$\downarrow$

G

1

-

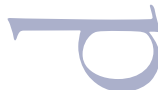

( )

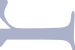

(U)

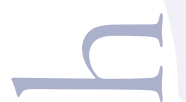




\title{
Rimski grob z zrcalcem z Lipičarjevega vrta na Mostu na Soči
}

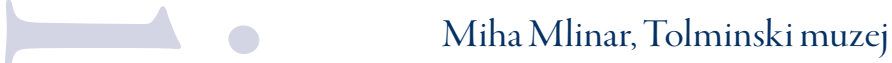 \\ Lipičarjevim z Mosta na Soči, iz Nove Gorice, Radencev in Beograda
}

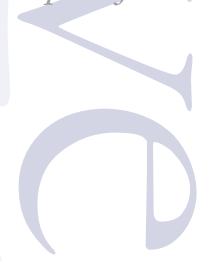

Na območju železnodobnega grobišča na Mostu na Soči je bil raziskan žgan rimski grob, verjetno s konca 3. stol.n. št., lahko pa je tudi mlajši. Odkritja posameznih rimskih grobov na prostoru železnodobnega grobišča kažejo na trdoživo tradicijo pokopavanja na levem bregu Idrijce. Železnodobna prežitka sta tudi način pokopa in izdelava grobne konstrukcije.

Ključne besede: Posočje, Most na Soči, rimska grobišča, žgan grob, svinčeno zrcalce

At Most na Soči within the Iron Age necropolis on the left bank of Idrijca river a roman cremation grave was uncovered. It's dated back to the 3 rd century, but could be even younger.

The discoveries of the individual roman graves within the area of the Iron Age cemetery show the tradition of burying at the left bank of the Idrijca river; a part of tradition are also the type of burying and the form of a grave construction.

Keywords: Posočje, Most na Soči, roman necropolis, cremation grave, lead mirror

M

ost na Soči je izjemno arheološko najdišč $\mathrm{z}$ odkritimi sledovi poselitve iz bronaste dobe, železne dobe, rimskega in poznoantičnega časa ter $\mathrm{z}$ najdbami iz zgodnjega srednjega veka in mlajših arheoloških obdobij. ${ }^{\mathrm{T}}$ Tolminski muzej je na parc. št. 949,

I O arheologiji Mosta na Soči glej: Carlo Marchesetti, La necropoli di S. Lucia presso Tolmino, scavi del I884 (Trieste: Tipografia del Lloyd Austriaco, 1886); Carlo Marchesetti "Scavi nella necropoli di S. Lucia presso Tolmino." Bollettino della Societá Adriatica di Scienze Naturali in Trieste 15, (1893): 3-320; Biba Teržan, Neva Trampuž. "Prispevek h kronologiji svetolucijske skupine," Arheoloski vestnik 24, (1973): 416-460; Stane Gabrovec, Stane, Drago Svoljšak, Most na Soči (S.Lucia) r. Katalogi in monografije 22 (Ljubljana: Narodni muzejSlovenije, 1983); Biba Teržan, Fulvia Lo Schiavo, Neva Trampuž Orel. Most na Soči (S. Lucia) I. Katalogi in monografije 23/1 (Ljubljana: Narodni muzej Slovenije, 1984); Biba Teržan, Fulvia Lo Schiavo, Neva Trampuž Orel. Most na Soči (S. Lucia) 2. Katalogi in monografije 23/2 (Ljubljana: Narodni muzejSlovenije, 1985); Mitja Guštin, Posočje v mlajsi železni dobi = Posočje in der jüngeren Eisenzeit. Katalogi in monografije 27 (Ljubljana: Narodni muzej Slovenije, 1991); Drago Svoljšak, "Posočje v bronasti dobi." Arheološki vestnik 39/40 (1988/89): 367- 386; "Zametki urbanizma vželeznodobni naselbini na Mostu na Soči." Arheološki vestnik 52 (2001): 131-138; Miha Mlinar, Nove zanke svetolucijske uganke. Arheološke raziskave na
943/I in 940/2 k. o. Most na Soči 5. 4. in II. 4. 2016 izvajal arheološko dokumentiranje ob izkopu treh jam za temelje betonskih drogov nizkonapetostnega omrežja. ${ }^{2}$ Med izkopom prve jame (TS I) je bil na parc. št. 949, k.o. Most na Soči na t.i. Lipičarjevem vrtu raziskan žgan rimskodoben grob, izkopa druge in tretje jame (TS 2,3) sta bila arheološko negativna.

Območje izkopov se nahaja na prostoru prostranega železnodobnega grobišča ${ }^{3}$ na levem

Mostu na Soči 2000 do 200 (Tolmin: Tolminski muzej, 2002); Miha Mlinar, Rok Klasinc, Martina Knavs. "Zaščitne arheološke raziskave na Mostu na Soči leta 200I. Najdišča Maregova guna, Štulčev kuk in Plac." Arheološki vestnik 59 (2008): 189-208.

2 Naročnik del je bila Elektro Primorska d.d. Arheološke raziskave je izvedla ekipa Tolminskega muzeja (Miha Mlinar) pod nadzorom ZVKDS OE Nova Gorica (Patricija Bratina). Kovinski predmeti so bili konservirani v delavnicah Goriškega muzeja v Solkanu (Jana Šubic Prislan, Andrej Ferletic), najdbe je izrisala Nataša Grum in jih hrani Tolminski muzej.

3 Glej: Marchesetti, La necropoli di S. Lucia presso Tolmino, scavidel I884, 1886; Marchesetti "Scavi nella necropoli di S. Lucia presso Tolmino." 1893; Teržan, Trampuž Orel, Lo Schiavo Most na Soči (S. Lucia) 
bregu reke Idrijce, ki je registrirana enota nepremične kulturne dediščine Most na Soči Arheološko najdišče Sveta Lucija (EŠD 470) in hkrati arheološki spomenik Občine Tolmin. Z območja železnodobnega grobišča so znani tudi posamezni rimskodobni grobovi, tako žgani ${ }^{4}$ kot tudi eden skeleten, ${ }^{5}$ sicer pa so Rimljani svoje pokojne pokopavali na desnem bregu Idrijce, vzhodno od naselbinskega prostora. ${ }^{6}$

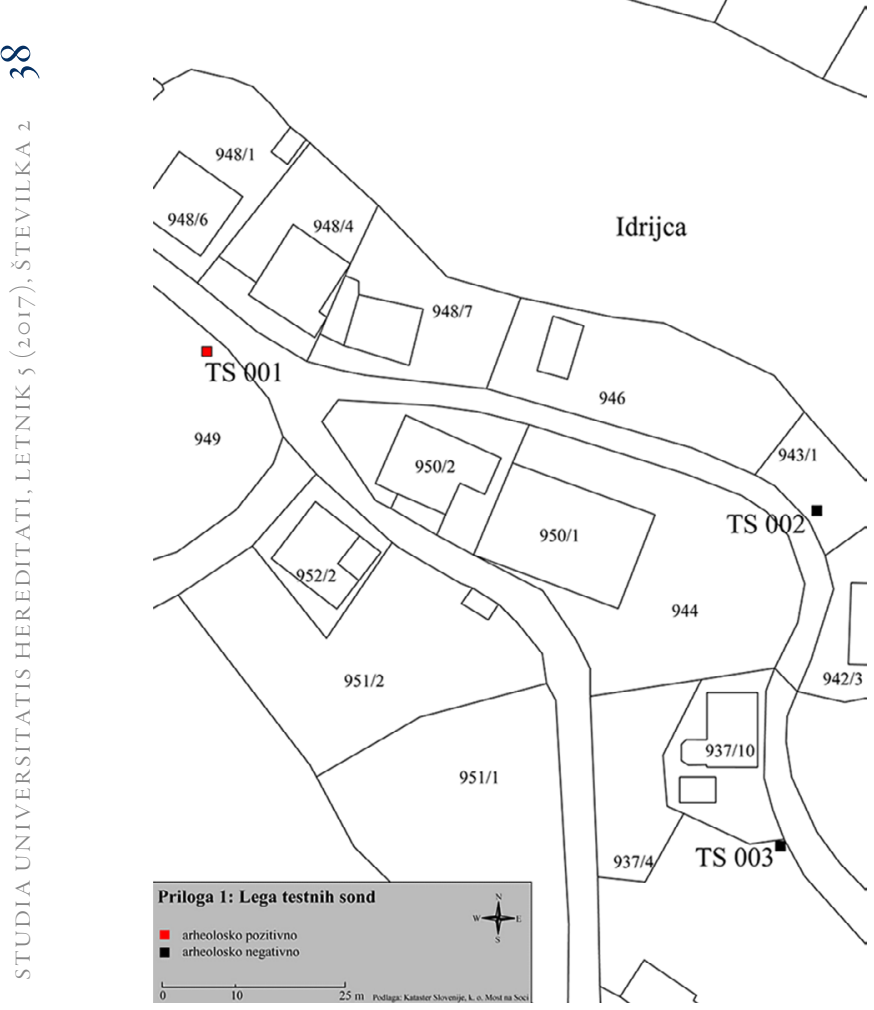

Slika I: Lega izkopanih jam I, 2 in 3 (izris: Ana Hawlina, podloga: Atlas Okolja Slovenije, ARSO).

I. 1984; Most na Soči (S. Lucia). 1985; Mlinar, Nove zanke svetolucijske uganke. Arheoloske raziskave na Mostu na Soči 2000 do 200I, 2002.

4 (Marchesetti, "Scavi nella necropoli di S. Lucia presso Tolmino," 321; Mlinar 2005: 334).

Mlinar 2005: 334, Fig. 8 .

6 To grobišče z okoli 180 grobovi je še neobjavljeno. Drago Svoljšak, Beatriče Žbona Trkman. "Načini pokopa v prazgodovini Posočja," Materiali 20 (1985): 88.

\section{Odkritje groba}

Arheološkega dokumentiranje ob gradnji se je izvajalo med strojnim odstranjevanjem ruše in gornjih zemljenih plasti (SE I, 2) v testni jami I (TS I). Arheološka sonda velikosti I30 x I30 $\mathrm{cm}$ je bila izkopana na zahodnem robu Lipičarjevega vrta (parc. št. 949, k.o. Most na Soči). Med strojnim odstranjevanjem ruše in zemljene plasti se je na globini $85 \mathrm{~cm}$ pojavila lapornata plošča, ki je nakazovala možnost obstoja žganega groba. Sledil je ročni arheološki izkop, s katerim je bil dokumentirano raziskan žgan grob s pridatki. Grobna jama je bila vkopana v ilovico vse do ravne geološke osnove, ki jo predstavlja apnenčasta plošča na globini $120 \mathrm{~cm}$ pod današnjo hodno površino. $Z$ zahodne strani so jamo obdajale zložene lapornate plošče. V močni žganini, debeline $25 \mathrm{~cm}$, ki je bila neposredno pod lapornato ploščo, so bili odkriti svinčeni okvir ogledalca, več odlomkov keramične oljenke, železna pločevina z dvema luknjicama ter steklene jagode, lesno oglje grmade in sežgane človeške kosti. Slednje so bile skoncentrirane na dnu grobne jame, nekaj koščic je bilo odloženih tudi na lapornato nagrobno ploščo. Približno 20 $\mathrm{cm}$ nad njo so bili v severnem profilu odkriti odlomki rimskodobnega vrča, kar verjetno predstavlja sled pogrebnega običaja.

Vsa žganina je bila med izkopom grobne jame zbrana in nato mokro presejana $\mathrm{v}$ Tolminskem muzeju. Med tem postopkom je bilo odkritih več najdb, predvsem drobnih steklenih jagod, drobcev oglja in sežganih človeških kosti. Človeški kostni ostanki so tehtali 545 g. Glede na opravljeno antropološko analizo gre verjetno za žensko, staro 20-40 let.

\section{Opredelitev grobnih najdb}

$\mathrm{V}$ žganini raziskanega žganega groba so bili odkriti svinčen okvir zrcalca, ${ }^{8}$ odlomki keramične oljenke, podrobneje neopredeljiva železna ploščica z dvema luknjama, steklene jagode ogrlice, $v$

\footnotetext{
Analizo je opravila dr. Petra Leben Seljak, neobjavljeno poročilo hrani Tolminski muzej.

8 Med postopkom spiranja žganine so bili odkriti tudi drobni delci stekla ogledala.
} 


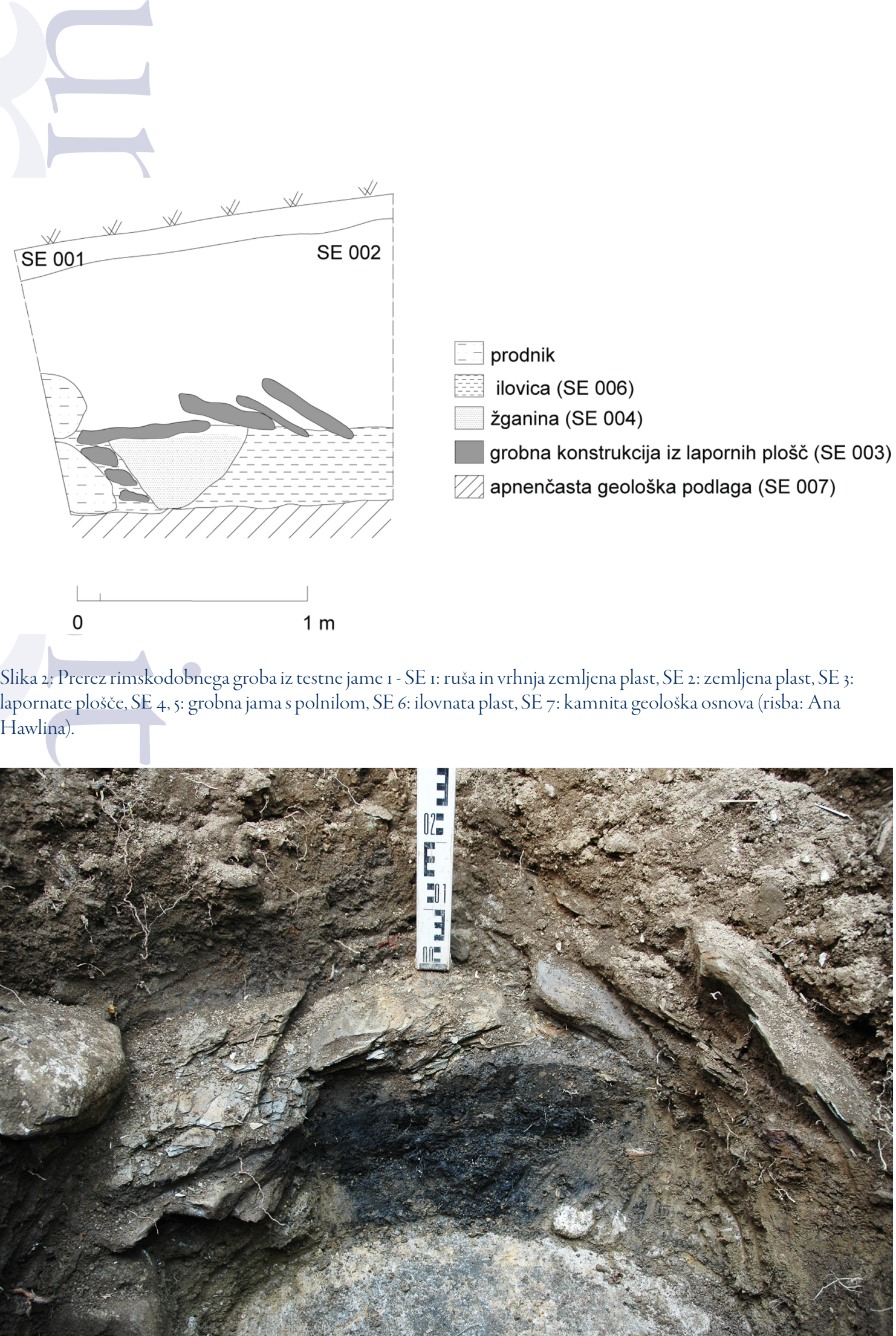

Slika 3: Pogled na grobno jamo pod lapornatimi ploščami (foto: Miha Mlinar, fototeka Tolminskega muzeja). 
profilu jame so bili nad lapornato ploščo odkriti še odlomki enoročajnega vrča.

Ogledalo je ženski simbol, ki je s svojo odsevajočo površino podloga študiju simbolike znanja, spoznanja in modrosti. ${ }^{9}$ Prenosna ogledalca (zrcalca) predstavljajo nepogrešljiv del ženskega toaletnega pribora in so bila $\mathrm{v}$ antiki izdelana predvsem iz srebra ali brona, veliko manj je bilo svinčenih. Majhna zrcala s trakastim svinčenim okvirjem in notranjosti iz stekla so znana že od zgodnje cesarske dobe dalje. Okvirji so bili po navadi dodatno okrašeni, lahko tudi z napisi, kar verjetno kaže tudi na njihovo apotropejsko funkcijo. Tudi edinstveni primerek z Mosta na Soči (kat. št. I) je po zunanji površini okrašen $\mathrm{z}$ geometrijskim okrasom.

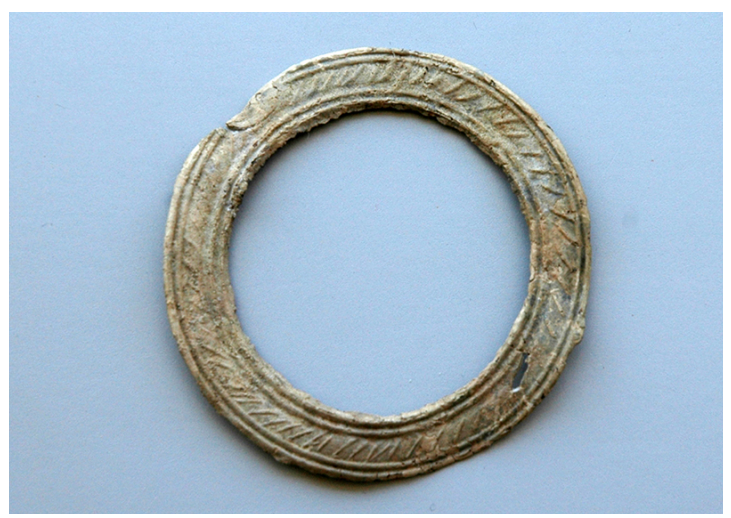

Slika 4: Svinčen okvir zrcalca iz žganine groba (foto: M. Mlinar, fototeka Tolminskega muzeja).

Svinčeni okvirji zrcalc so značilni predvsem za drugo polovico 3. in 4 . stoletje n. št. in so vezani na široko območje med Malo Azijo, srednjo Evropo in Mediteranom, veliko jih je bilo odkritih tudi na balkansko-panonskem prostoru. Glede na analizo grobnih pridatkov je jasno, da so bila svinčena zrcalca značilen pridatek znotraj ženskih grobov, ${ }^{11}$ hkrati pa so to lahko tudi na-

9 Jean Chevalier, Alain Gheerbrant. Slovar simbolov. Miti, sanje, liki, običaji, barve, stevila (Ljubljana: Mladinska knjiga, 1993), 40I-402.

Io Primerjaj Dragana Spasić, "Antička olovna ogledala iz Narodnog muzeja u Požarevcu = Antique Lead Mirrors from the National Museum in Požarevac." Viminacium Io, (1995), 29-68.

I I Tudiglede na opravljeno antropološko analizo gre verjetno za ženski pokop. jdbe iz kultnih zakopov, ki so bili v povezavi z ženskimi božanstvi, Hero, Venero ali Nimfo. ${ }^{\mathrm{I2}}$ Glede na razprostranjenost in časovno umestitev se domneva, da je izvor svinčenih zrcalc potrebno iskati na podonavsko-balkanskem prostoru, od koder so se razširjali proti Nemčiji na eno in proti Krimu na drugo stran. Zrcalca okrogle oblike, kot je primerek z Mosta na Soči, so značilna predvsem za 3. in 4. stol. n. št. in so vezana na bližnja italska območja, saj jih je največ bilo odkritih prav v Ogleju. ${ }^{13}$ V Sloveniji je takih najdb malo. Svinčenemu okvirju mostarskega zrcalca je po velikosti in okrasu povsem primerljiv okrogel okvir iz posavskega Nevioduna. ${ }^{14}$ Glede na primerjave okrasne motivike zunanje površine je mogoče, da so te najdbe tudi na akvilejski prostor prišle iz Panonije, morda že v zadnjih desetletjih 2. stoletja. ${ }^{15} \mathrm{Na}$ širokem severoitalskem prostoru med Milanom, Padom in Trentom pa so bili okrogli svinčeni okvirji zrcalc sicer odkriti predvsem $v$ grobovih 4 . ali celo zgodnjega 5 . stoletja n. št. ${ }^{16}$

Oljne svetilke ali oljenke so bile osnovno svetilo za osvetlitev bivališč za časa Rimljanov. Prav pogoste so v grobovih, kjer so pokojnemu razsvetljevale večno temo. Veliko jih je bilo odkritih tudi na Mostu na Soči, tako znotraj naselbine kot tudi grobišča. ${ }^{17}$ Uporaba poznih pečat-

I2 Giulia Baratta, "Ars plumbaria Sardiniae? Gli specchietti in piombo del Museo Archeologico G.A. Sanna di Sassari: appunti preliminari per un catalogo generale,"V LAfrica romana, I luoghi e le forme dei mestieri e della produzione nelle province africane, Atti del XVIII Convegno di Studio, ur. Marco Milanese, Paola Ruggeri, Cinzia Vismara, (Roma: Carocci 2010), 1 I55; Uboldi, Marina. "Specchietti simbolici in vetro e piombo dalle necropoli milanesi dell'Università Cattolica e di via Madre Cabrini." V Archeologia classica e post-classica tra Italia e Mediterraneo. Scritti in ricordo di Maria Pia Rossignani. Contributi di archeologia 8, ur. Silvia Lusuardi Siena et al., 97-106 (Milano: Vita e Pensiero, 2016)

I3 Maurizio Buora, Magnani, Stefano. "Cornici in piombo per specchi da Aquileia e dal suo territorio." Instrumentum 4I, (2015), I7.

I4 Sonja Petru, Peter Petru. Neviodunum (Drnovo pri Krškem). Katalogi in monografije is (Ljubljana: Narodni muzej Slovenije, 1978), 67, T. 22: 19 .

I5 Buora, Magnani, "Cornici in piombo per specchi da Aquileia e dal suo territorio," 17

I6 Corti, Carla 2016. "Cornici in piombo per specchi: nuovi ritrovamenti dall'Aemilia." Quaderni Friulani di Archeologia 25, (2015), 192.

I7 Miha Mlinar, Verena Perko, Beatrice Žbona Trkman 2015: "Rimskodobne oljenke z Mosta na Soči: naselbina, grobišče II, najdišče Repelc." Goriški letnik 37-38 (2013-2014): I15-123. 
nih oljenk z odprtim kanalom vrste Loeschcke X oz. Buchi X, kakršna je bila fragmentarno odkrita znotraj žganega groba z Lipičarjevega vrta na Mosta na Soči (kat. st. 3), gre lahko v 3. in 4 . stoletje. ${ }^{18}$ To nakazuje npr. oljenka iz groba $8 \mathrm{z}$ grobišča Javor pri Dolnjem Zemonu ${ }^{\text {19 }}$ kot tudi primerljive najdbe $\mathrm{z}$ rimskodobnega grobišča na desnem bregu Idrijce na Mostu na Soči. ${ }^{2}$

Steklene jagode so značilen pridatek ženskih grobov, a so datacijsko precej neobčutljive. Primerljive dvo in veččlenaste sodčaste jagode ter modre bikonične jagode, kakršne so bile odkrite v grobu z Lipičarjevega vrta (kat. št. s), se lahko namreč pojavijo že v grobovih iz 2 . polovice 2. stoletja, ${ }^{22}$ lahko jih dobimo v poznorimskih grobovih, kot kažejo npr. najdbe z grobišča Pristava na Bledu, ${ }^{23}$ ali celo $\mathrm{v}$ zgodnjesrednjeveških kontekstih. ${ }^{24}$

Zaradi nekaterih grobnih pridatkov, ki so lahko bili v skoraj nespremenjenih oblikah v uporabi daljše časovno obdobje (steklene jagode, oljenka), je časovna opredelitev te grobne celote lahko problematična. Predvsem glede na najdbo svinčenega okvirja zrcalca pa jo verjetno lahko umestimo na konec 3. ali v 4. stoletje. $\mathrm{Na}$ os-

Primerjaj: Janka Istenič, Poetovio, zahodna grobišca I. Grobne celote iz Dezzelnega muzeja Joaneumav Gradcu= Poetovio, the western cemeteries I. Grave-Groups in the Landesmuseum Joaneum, Graz. Katalogi in monografije 32 (Ljubljana: Narodni muzej Slovenije, 1999), 153, 157; Verena Vidrih Perko, Aleksandra Nestorović, Ivan Žižek. Ex Oriente Lux: Roman lamps from Slovenia. 4th International Congress of ILA on Lamps (Ptuj: Pokrajinski muzej Ptuj Ormož, 2012).

19 Jana Horvat, Beatrice Žbona Trkman. "The zrd century military equipment in south-western Slovenia." V: ur. Jana, Horvat. The Roman army between the Alps and the Adriatic. Opera Instituti Archaeologici Sloveniae 3i (Ljubljana: ZRC SAZU, Inšstitut za arheologijo, Založba ZRC, 2016), I14

20 Mlinar, Perko, Žbona Trkman, "Rimskodobne oljenke z Mosta na Soči: naselbina, grobišče II, najdišče Repelc," ${ }_{11} 18-120$, kat. št. 12, 15, 17 .

21 Primerjaj Vladimira Bertoncelj Kučar, "Nakit iz stekla in jantarja." Arheološki vestnik 30, (1979), 257

22 Claudia Casagrande, "L'età Romana." V: Belluno. Storia di una provincia dolomiticha. Dalla preistoria all'epoca Romana I, ur. Paolo Conte, 217-322 (Udine: Forum, 2013), 274, sl. 57.

23 Timotej Knific, "Pridatki izženskega groba." V: OdRimljanov do Slovanov. Predmeti, ur. Polona Bitenc, Timotej Knific (Ljubljana: Narodni muzej Slovenije, 200I), kat. št. I24.

24 Polona Bitenc, "Ogrlice." V: Od Rimljanov do Slovanov. Predmeti, ur. Polona Bitenc, Timotej Knific, (Ljubljana: Narodni muzej Slovenije, 200I), kat. št. 277 novi dejstva, da je bil pokop žgan in izveden še povsem v železnodobni tradiciji, ${ }^{25}$ je verjetnejša datacija konec 3. stoletja. V 4. stoletju so namreč že pričeli postopno opuščati obred sežiganja pokojnih na grmadi in s tem pokop sežganih kosti, kar je bilo z uvedbo krščanstva ob koncu 4 . stoletja dokončno prepovedano.

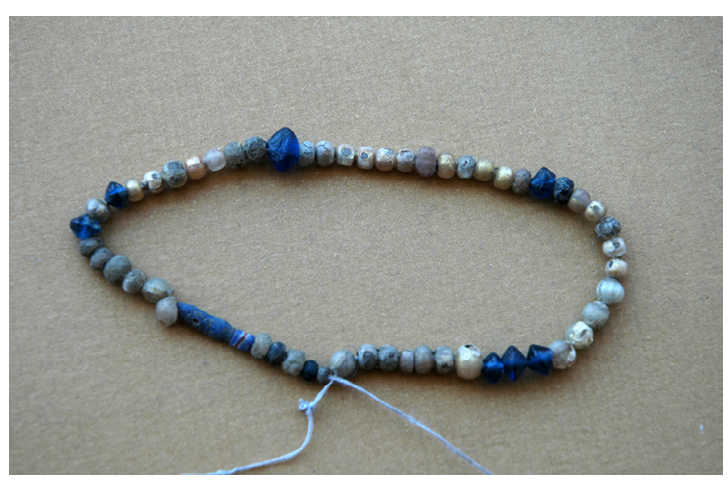

Slika s: Poskus rekonstrukcije ogrlice iz steklenih jagod (foto: M. Mlinar, fototeka Tolminskega muzeja).

\section{Zaključek}

Na parc. št. 949, k.o. Most na Soči na Mostu na Soči (Lipičarjev vrt) je bil med arheološkim dokumentiranjem ob izkopu za temelj betonskega droga raziskan rimskodoben žgan grob, ki ga glede na pridatke (svinčen okrogel okvir zrcala, fragmentarno ohranjena lončena pečatna oljenka, odlomki vrča, steklene jagode ogrlice) lahko opredelimo verjetno na konec 3. ali v 4. stoletja n. št.

Prvi znani podatek o arheoloških najdbah z Lipičarjevega vrta je iz leta 1960, ko so pri urejanju obcestnega jarka nasproti Žagarjeve hiše (Most na Soči 78 ) odkrili delno uničen žgan grob. ${ }^{26}$ Tradicija pokopavanja na tem

25 Grobna jama je bila pokrita z lapornatimi ploščami, tako kot velika večina starejšeželeznodobnih grobov z Mosta na Soči. Žganina je bila posuta na dno grobne jame, žare ni bilo.

26 Marija Rutar, Most na Soči. Varstvo spomenikov 8 (1960/1961), 229; Drago Svoljšak, "Kronologija raziskovanj s topografskimi podatki." V: Gabrovec, Stane, Drago, Svoljšak. Most na Soči (S.Lucia) I. Katalogi in monografije 22 (Ljubljana: Narodni muzej Slovenije, 1983), 34.V poročilu je Marija Rutar (1960-1961: 229) zapisala, da je to parcelo že prekopal tržaški raziskovalec Carlo Marchesetti, na topografski karti (Drago Svoljšak, "Kronologija raziskovanj s topografskimi podatki," Sl. I8) pa je prostor označeno kot neraziskan. 
prostoru je železnodobna, saj se območje nahaja znotraj areala prostranega železnodobnega grobišča. Rimljani so že v času romanizacije osnovali svoje pokopališče na desnem bregu Idrijce, zunaj naselbine. ${ }^{27} \mathrm{~S}$ tem so poskusili izkoreniniti tradicijo pokopavanja na levem bregu Idrijce, kar jim je očitno le delno uspelo, ker je lokalno prebivalstvo tam še vedno posamično pokopavalo svoje pokojne. ${ }^{28} \mathrm{Na}$ to kaže tudi odkritje groba $\mathrm{z}$ Lipičarjevega vrta. ${ }^{29}$ Čeprav je bil pokop izveden že stoletja po romanizaciji širšega prostora, je potrebno poudariti, da je iz obredja razvidno izrazito upoštevanje lokalnih, globoko zakoreninjenih posoških kulturnih vzorcev, ki so morda še odsev železnodobnih navad. Pokop je bil žgan, žganina je bila položena neposredno na dno grobne jame, brez uporabe žare, grob pa je bil prekrit in delno obdan z lapornatimi ploščami.

Odkritje rimskodobnega groba $\mathrm{z}$ Lipičarjevega vrta kaže, da je ta prostor na levem bregu Idrijce na Mostu na Soči verjetno arheološko še povsem nepregledan in je, kot lahko domnevamo glede na veliko globino vkopa za grobno jamo, ostal tudi nepoškodovan. V bližini odkritja obravnavanega groba je velika možnost obstoja neraziskanih železnodobnih in rimskodobnih grobov; predvsem slednji bi bili so za študij razumevanja prepleta lokalne in rimske kulture še kako zanimivi.

\section{Katalog najdb}

I. V kalup odlit svinčen okvir zrcala okrogle oblike, ob zunanjem in notranjem robu traku sta dve obrobi z motivom poševnih črt, zrcalcu pripadajo še drobci

27 Svoljšak, Žbona Trkman. "Načini pokopa v prazgodovini Posočja." $87-89$.

28 Marchesetti, "Scavi nella necropoli di S. Lucia presso Tolmino," 3-320; Mlinar "Most na soči (S. Lucia di Tolmino): a century after Carlo Marchesetti," 325-338.

29 Glede na lego obravnavanega groba in odkritij ostalih rimskodobnih grobov z ledine Repelc (prim. Mlinar, Nove zanke svetolucijske uganke. Arheoloske raziskave na Mostu na Soći 2000 do 20oI; Mlinar "Most na soči (S. Lucia di Tolmino): a century after Carlo Marchesetti," 325-338), lahko glavnino rimskodobnih grobov domnevamo na najnižji rečni terasi Idrijce, medtem ko je središčni del starejšeželeznodobnega grobišča obsegal predvsem drugo idrijsko teraso. konveksnega stekla. Zun. pr. 5,3 cm, notr. pr. $3,7 \mathrm{~cm}, \mathrm{db} . \circ, \mathrm{I} \mathrm{cm}$; inv. št. TM 2483 .

2. Železna trakasta pločevina $\mathrm{z}$ dvema luknjama, morda rezilo noža. $\mathrm{Dl}$. II, $4 \mathrm{~cm}$, š. do $3,3 \mathrm{~cm}$; inv. št. TM 2484 .

3. Odlomki gornjega dela $\mathrm{z}$ delom ročaja in dna enoročajnega vrča peščene barve. Rek. pr. ustja $5,2 \mathrm{~cm}$, rek. pr. dna $5 \mathrm{~cm}$, inv. št. TM 2485.

4. Odlomki gornje ploskve in del dna keramične pečatne oljenke opečnate barve, verjetno vrste Loeschcke Xc. Ohr. dl. $8 \mathrm{~cm}$, v. 3,9 cm; inv. št. TM 2486.

5. Steklene jagode ogrlice. V celoti ohranjenih 46 jagod iz modre in prozorne steklene paste s pozlato, od teh je 7 bikoničnih modrih jagod, I cevasta modra jagoda, I drobna jagoda kvadraste oblike z modrimi, belimi in rdečimi črtami ter pozlačene eno in dvočlenaste sodčaste jagode. Pr. jagod od 0,3 do o,8 cm; inv. št. TM 2487.

\section{Povzetek}

Na Mostu na Soči so leta 2016 arheologi Tolminskega muzeja na levem bregu Idrijce, na območju železnodobnega grobišča, raziskali žgan rimski grob, ki ga na osnovi pridatkov (svinčeni okvir zrcalca, odlomki keramične oljenke, steklene jagode, odlomki enoročajnega vrča) lahko opredelimo na konec 3. stol. n. št., lahko pa je tudi mlajši. Grob je eden redkih rimskih grobov, ki je bil odkrit na prostoru železnodobnega grobišča, saj so si Rimljani organizirali svoje pokopališče na desnem bregu Idrijce. Lokalno prebivalstvo očitno ni povsem prekinilo $s$ tradicijo pokopavanja na tem prostoru, prav tako je zakoreninjenost železnodobne tradicije razvidna tudi $v$ načinu pokopa in grobne konstrukcije.

\section{Abstract}

In 2016 the Tolmin museum archaeologists excavated roman cremation grave at the place of Iron Age necropolis on the left bank of Idrijca river. On the base of the grave goods (lead mirror frame, fragments of the oil lamp, glass beads, fragments of a jug) it can be dated to the end of the 3 rd century AD, but it could be also younger. A grave is one of the rare roman graves discovered within Iron Age cemetery, because the Romans organized their own 

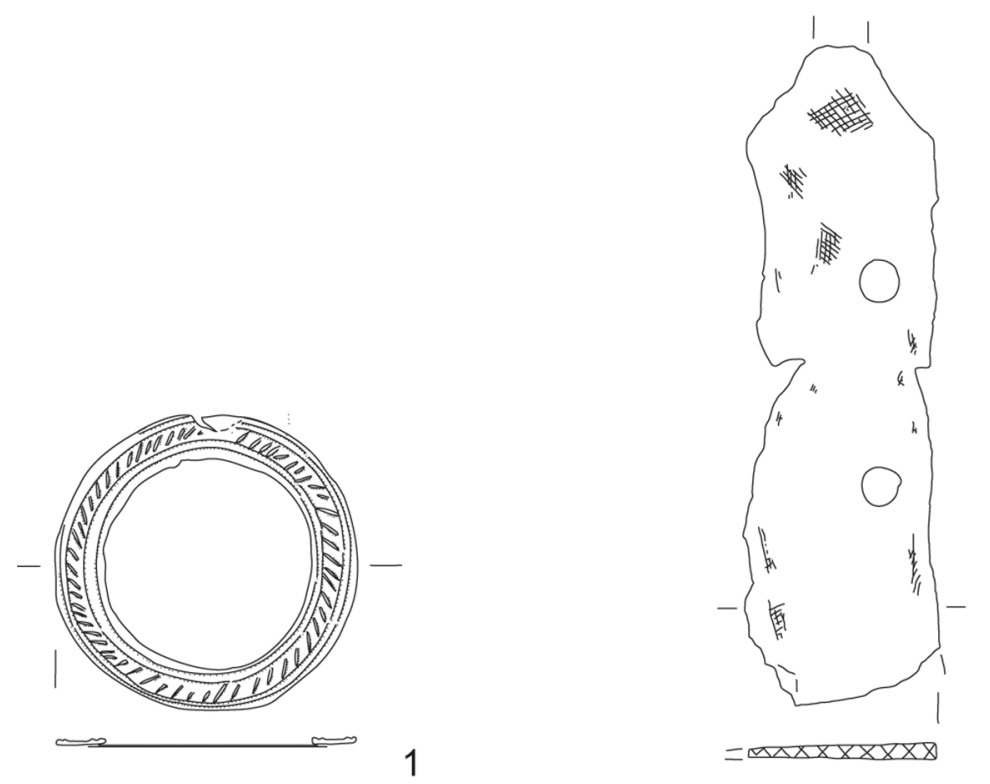

年
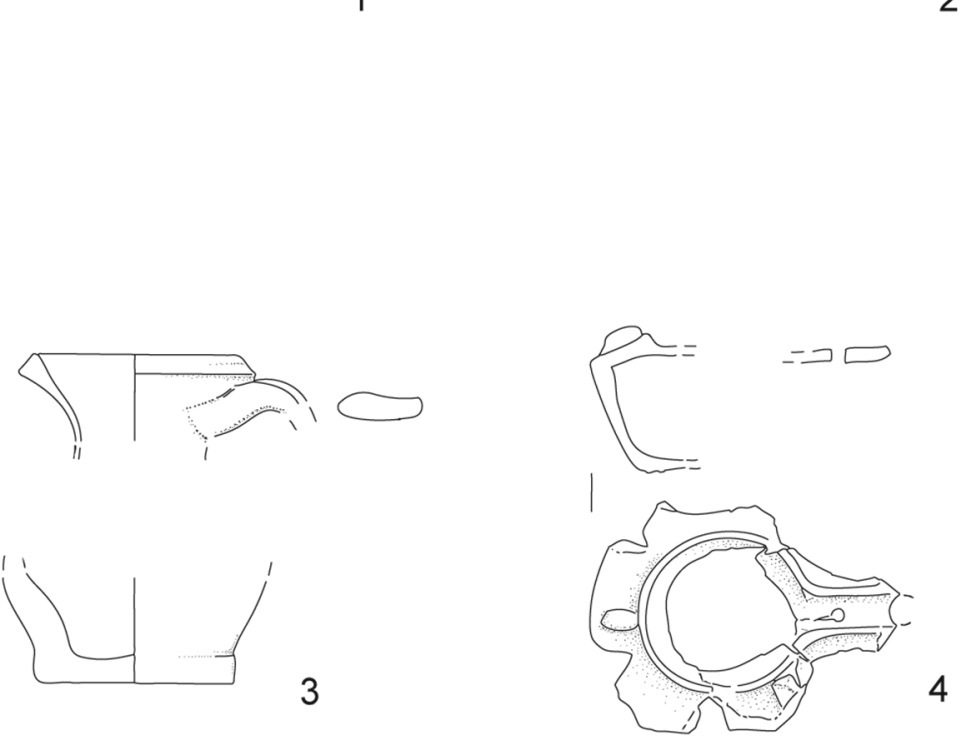

2

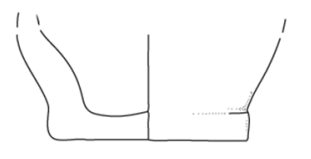

3

Tabla I

graveyard on the right bank of Idrijca river. The local population obviously not fully terminated with the tradition Age tradition can be also seen from the type of burying of burying theirs on the left bank of Idrijca river; the Iron and the form of a grave construction. 


\section{Literatura}

Baratta, Giulia. "Ars plumbaria Sardiniae? Gli specchietti in piombo del Museo Archeologico G.A. Sanna di Sassari: appunti preliminari per un catalogo generale," V L'Africa romana, I luoghi e le forme dei mestieri e della produzione nelle province africane, Atti del XVIII Convegno di Studio, ur. Marco Milanese, Paola

Ruggeri, Cinzia Vismara, II5I-I168. Roma: Carocci 2010.

Bertoncelj Kučar, Vladimira. "Nakit iz stekla in jantarja." Arheološki vestnik 30, (1979): 254-277.

Bitenc, Polona. "Ogrlice." V: Od Rimljanov do Slovanov. Predmeti, ur. Polona Bitenc, Timotej Knific, 277, Ljubljana: Narodni muzej Slovenije, 200 I.

Buora, Maurizio. Magnani, Stefano. "Cornici in piombo per specchi da Aquileia e dal suo territorio." Instrumentum 4I, (2015): I5-24.

Casagrande, Claudia. "L’età Romana." $\mathrm{V}$ : Belluno. Storia di una provincia dolomiticha. Dalla preistoria all'epoca Romana I, ur. Paolo Conte, 217-322. Udine: Forum, 2013.

Chevalier, Jean. Alain Gheerbrant. Slovar simbolov. Miti, sanje, liki, običaji, barve, števila. Ljubljana: Mladinska knjiga, 1993.

Corti, Carla 2016. "Cornici in piombo per specchi: nuovi ritrovamenti dall'Aemilia. "Quaderni Friulani di Archeologia 25, (2015): 189-194.

Gabrovec, Stane. Drago, Svoljšak. Most na Soči (S.Lucia) I. Katalogi in monografije 22, Ljubljana: Narodni muzej Slovenije, 1983. Guštin, Mitja. Posočjev mlajši železni dobi= Posočje in der jüngeren Eisenzeit. Katalogi in monografije 27, Ljubljana: Narodni muzej Slovenije, I991.

Horvat, Jana., Beatriče Žbona Trkman. “The 3rd century military equipment in southwestern Slovenia." V: ur. Jana, Horvat. The Roman army between the Alps and the Adriatic. Opera Instituti Archaeologici
Sloveniae 31, 99-I20. Ljubljana: ZRC SAZU, Inštitut za arheologijo, Založba ZRC, 2016.

Istenič, Janka. Poetovio, zahodna grobišča I. Grobne celote iz Deželnega muzeja Joaneuma $v$ Gradcu = Poetovio, the western cemeteries I. Grave-Groups in the Landesmuseum Joaneum, Graz. Katalogi in monografije 32, Ljubljana: Narodni muzej Slovenije, 1999.

Knific, Timotej. "Pridatki iz ženskega groba." V: Od Rimljanov do Slovanov. Predmeti, ur. Polona Bitenc, Timotej Knific, Ljubljana: Narodni muzej Slovenije, 200 I.

Maggi, Paola. Beatriče Žbona Trkman 2007: "Tra Natisone e Isonzo: il territorio in età romana." V: Le valli del Natisone e dell Isonzo tra Centroeuropa e Adriatico, ur. Monica Chiabà, Paola Maggi, Chiara Magrini, 59-77. Studi e ricerche sulla Gallia Cisalpina 20, S. Pietro al Natisone: Quasar, 2007.

Marchesetti, Carlo. La necropoli di S. Lucia presso Tolmino, scavi del I884. Trieste: Tipografia del Lloyd Austriaco, 1886.

Marchesetti, Carlo. "Scavi nella necropoli di S. Lucia presso Tolmino.” Bollettino della Società Adriatica di Scienze Naturali in Trieste 15, (1893): 3-320.

Mlinar, Miha. Nove zanke svetolucijske uganke. Arheološke raziskave na Mostu na Soči 2000 do 20or. Tolmin: Tolminski muzej, 2002.

Mlinar, Miha. "Most na soči (S. Lucia di Tolmino): a century after Carlo Marchesetti." V: Carlo Marchesetti e i castellieri 1903 - 2003. Atti del Convegno Internazionale di Studi. Castello di Duino (Trieste), I4-IS novembre, Fonti e studi per la Storia della Venezia Giulia, ur. Emanuela Montagnari Kokelj, 325-338, Trieste: Editreg, 2005.

Mlinar, Miha., Rok Klasinc, Martina Knavs. "Zaščitne arheološke raziskave na Mostu na Soči leta 200I. Najdišča Maregova guna, Štulčev kuk in Plac." Arheološki vestnik 59 (2008): 189-208.
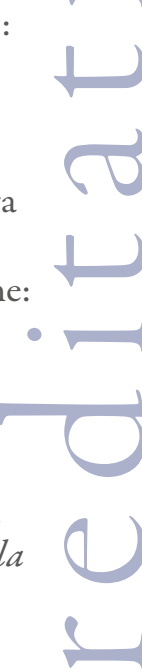

○

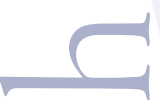


Mlinar, Miha., Verena Perko., Beatriče Žbona Trkman. 2015: "Rimskodobne oljenke z Mosta na Soči: naselbina, grobišče II, najdišče Repelc." Goriški letnik 37-38 (2013-2014): 115-123.

Petru, Sonja., Peter Petru. Neviodunum (Drnovo pri Krškem). Katalogi in monografije is. Ljubljana: Narodni muzej Slovenije, 1978.

Rutar, Marija. Most na Soči. Varstvo spomenikov 8 (1960/196I): 229.

Spasić, Dragana. "Antička olovna ogledala iz Narodnog muzeja u Požarevcu = Antique Lead Mirrors from the National Museum in Požarevac." Viminacium Io, (1995): 2968.

Svoljšak, Drago. "Kronologija raziskovanj s topografskimi podatki." V: Gabrovec, Stane., Drago, Svoljšak. Most na Soči (S.Lucia) I. Katalogi in monografije 22, Ljubljana: Narodni muzej Slovenije, 1983. Svoljšak, Drago. “Most na Soči (S. Lucia) I. Zgodovina raziskovanj in topografija = Storia delle ricerche e topografia." V: Gabrovec, Stane., Drago, Svoljšak. Most na Soči (S.Lucia) I. Katalogi in monografije 22, Ljubljana: Narodni muzej Slovenije, 1983.

Svoljšak, Drago. "Posočje v bronasti dobi." Arheološki vestnik 39/40 (1988/89): 367386.

Svoljšak, Drago. “Zametki urbanizma v železnodobni naselbini na Mostu na Soči." Arbeološki vestnik 52 (200I): I3I-I38.

Svoljšak, Drago., Beatrice Žbona Trkman.

"Načini pokopa v prazgodovini Posočja." V: Materiali 20 (1985): 87-89.

Teržan, Biba., Neva Trampuž. "Prispevek h kronologiji svetolucijske skupine.” V: Arheološki vestnik 24, (1973): 416-460.

Teržan, Biba., Francesca Lo Schiavo., Neva Trampuž Orel. Most na Soči (S. Lucia) I. Katalogi in monografije 23/r , Ljubljana: Narodni muzej Slovenije, 1984.

Teržan, Biba., Fulvia Lo Schiavo, Neva Trampuž Orel. Most na Soči (S. Lucia) 2.
Katalogi in monografije 23/2, Ljubljana: Narodni muzej Slovenije, 1985.

Uboldi, Marina. "Specchietti simbolici in vetro e piombo dalle necropoli milanesi dell'Università Cattolica e di via Madre Cabrini." V Archeologia classica e postclassica tra Italia e Mediterraneo. Scritti in ricordo di Maria Pia Rossignani. Contributi di archeologia 8, ur. Silvia Lusuardi Siena et al., 97-106. Milano: Vita e Pensiero, 2016.

Vidrih Perko, Verena. Aleksandra Nestorović, Ivan Žižek. Ex Oriente Lux: Roman lamps from Slovenia. 4th International Congress of ILA on Lamps. Ptuj: Pokrajinski muzej Ptuj Ormož, 2012. 
-

r

$\downarrow$

G

1

-

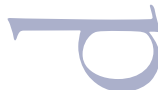

( )

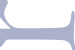

(U)

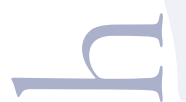




\title{
Forensics and Archaeology: The Ethical Approach to Graves Excavation and Research
}

\author{
Zdravka Hincak, University of Zagreb, Faculty of Humanities and Social Sciences
} Krešimir Filipec, University of Zagreb, Faculty of Humanities and Social Sciences

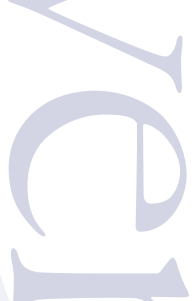

Ali obstaja razlika med metodami in tehnikami, ki se uporabljajo v arheologiji in forenzični arheologiji? Opisan je grob z arheološkega najdišča Josipovac - Verušed pri Osijeku (Slavonija, Hrvaška) odkrit leta 2007 , ki prepleta oz. povezuje obe področji. Med zaščitnimi arheološkimi izkopavanji na trasi avtoceste (A 5) Beli Manastir - Osijek so odkrili grob neznanega vojaka iz druge svetovne vojne. Pojasnjen je pomen poudarjanja konteksta, ki je omogočil umestitev odkritij oz. najdb v forenzični okvir. Po primerjavi metod, tehnik in tehnologij, ki jih uporabljata arheologija in forenzična arheologija, smo poskušali ugotoviti, kaj pomenita etika in bioetika za obe disciplini ter kako razmišljati o teh pojmih v arheološkem smislu.

Ključne besede: forenzična arheologija, grob, etika, druga svetovna vojna

Is there a difference between the methods and techniques used in archeology and forensic archaeology? A grave from archaeological site Josipovac - Verušed near Osijek (Slavonia, Croatia) in 2007, which permeates both areas was described. The burial pit of an unknown soldier from World War II was revealed during an archaeological rescue excavation on the route of the highway (A 5) Beli Manastir - Osijek. The importance of giving emphasis to the context, which enabled classification of the findings in the forensic framework, was explained. After the comparison of methods, techniques and technologies used by both archaeology and forensic archaeology, we have tried to determine what meaning have ethics for the two disciplines, as well as how to think about these concepts in the archaeological sense.

Key words: forensic archaeology, grave, ethics, World War II

$\mathrm{D}$ evelopment of the archaeological field methods and techniques did not follow the interest of beautiful, antique, valuable objects that interested antiquarians from the very beginning. Indeed, since the prehistoric times, archaeological sites' and graves' robbers have mercilessly devastated the world heritage. But if we mention the history of archaeological research we also need to mention the first archaeological excavations of the civilizations that left their ruins in the Mediterranean, in the Middle East and later, in Americas.
The first organized archaeological excavations were carried out in Croatia at the I9th century and they slowly laid foundations for today's surveys, introducing the very base of archaeological methods of the field research: setting up a one-meter grid square for excavation or a baseline offset. Together with classical tools for manual excavating, such as shovels, digging spades or mattocks, there are also mentioned small excavation tools for fine digging and cleaning, a simple trowel or a brush to sweep the dirt.

The archaeological field research shows not only what has remained after people who 
lived in a certain area, but also, using the physical traces of past societies, reconstructs events, examines what people did in a particular area, how did they think, and lived. All this can be read from an archaeological site; it is important to leave findings in situ, to record them, to document all the small pieces that later, put together, will give much more data. Similar to piecing together evidence in forensics. The archaeological field methods became a part of the forensic investigation tools before archaeologists did. According to the definition, the forensic archaeology is an application of the archaeological paradigms, methods and goals to the questions of medico-legal significance.

But a possible problem for an archaeologist involved in forensics, the medico-legal investigation, are not different methods or new technologies in the field work. Huglund explains it well: "Archaeological context in a forensic case includes the rules of evidence, the chain of custody, the potential that a court testimony may be required, and the fact that the activities and work of archaeologists may be subjected to legal scrutiny." Archaeologists got involved and became more frequent members of forensic teams during the 1990s, often united with physicians, odontologists, radiologists and criminalists in the investigations of human rights' violations, or revealing the evidence of mass murders as in Rwanda, Bosnia and Herzegovina, Croatia. With a strong contribution in developing recovery techniques at crime scenes and knowledge to elaborate techniques for the excavation of sites, forensic archaeology has a possibility to become a sub-discipline. Today, the unwritten criteria for a forensic archaeologist is to spend at least three full years of fieldwork on sites encompassing open sites, structural sites, burial sites, caves, and well or latrine sites.

Melissa Connor and Douglas D. Scott, "Paradigms and Perpetrators," Historical Archaeology 35, no. I (2001): I-6.

William D. Haglund, "Archaeology and Forensic Death Investigations," Historical Archaeology 35, no. I (2001): 26-34

Douglas D. Scott and Melissa Connor, "The Role and Future of Archaeology in Forensic Science," Historical Archaeology 35, no. I (200I): $10 \mathrm{I}-104$

\section{Material and methods}

The archaeological site Josipovac - Verušed is situated southwest of Josipovac (AN I5) in Slavonia region, Croatia. In the past, it was a village, and today it is a suburb of the town of Osijek in Osijek - Baranja County. Rescue excavations were performed on this site from 2007 to 2008 , on the route of the highway Beli Manastir - Osijek. The excavated area occupied $171000 \mathrm{~m}^{2}$ (Fig I). During the excavation of this large prehistoric and medieval settlement, a grave of a soldier from World War II was discovered. This finding was unexpected for an archaeological site, so all standard procedures that precede an excavation had already been made. Following the sequences of archaeological layers, contours of a possible burial pit emerged as a darker layer of earth (Fig 2). Analysis of its relations to other geological and cultural layers showed that it was not an old cultural layer from the Prehistoric, Roman or Medieval period. Immediately a doubt emerged, it was possible that the finding was a recent burial (in archaeological terminology recent burials are about 50-60 years old, up to a maximum of Ioo years old). The appearance pattern of burial pits from past wars (World War II and the Croatian War of Independence) is well known in that part of Slavonia, from previous archaeological excavations. It is a consequence of taphonomy - decomposition of the body and other natural processes.

Deposits of earth were removed by machine and lately by hand. It is important to mention that in the stratigraphic sequences, after exposition of human remains in double graves, trace boundaries between each skeleton or anatomical element were set. The excavation of the specific burial pit was carried out using traditional archaeological methodology, removing layer after layer and documenting each stage of work with photographs and drawings. From the photographs it is evident that the excavation and the exhumation did not just blindly follow the stratigraphy, but also the body extension, which was later of a great help to the anthropologist, providing an opportunity to obtain additional data 
on the individual. At the end of the research, the position of the skeleton and the burial pit were recorded with a total station or TST (TST Leica TCR805 and multi-element array antennas for GPS recording Leica System 900 GNSS), a distance measuring and diverse mapping electronic theodolite. TST is also used for precise measuring of objects in small excavations. Now, the finding - the skeleton and the burial pit - were located in the area in relation to the geographical points. The documentation was extensive, with complete burial sheets and application forms. The grave was given a number, it was marked as VE '07, grave Io with excavation data I8th October 2007 and basic information on its orientation, circumstances of the finding and basic anthropological analysis (approximate age at death and sex). In the forms were written data about the method of excavation. After a thor- ough cleaning of the burial pit and the skeleton in situ, the finding was drawn and photographed with a digital camera. Selected targets, the photo points, were recorded with a total station and fed into the GIS system (Geographical Information System) that covers the entire site and a wider region, as well as the whole county. Several times during the excavation, after finishing each major phase of the research, photogrammetric surveying of the site was made, using light aerial platforms. In this specific research, it included a system with helium-filled balloons and a Picavet platform (NCP case), and also the help of a paraglider (Fig I,2). In both cases, photographs were taken with a professional digital camera Canon EOS $\mathrm{ID}$. Photographs are stored in the Phototeque of Department of Archaeology (Faculty of Humanities and Social Sciences, University in Zagreb).

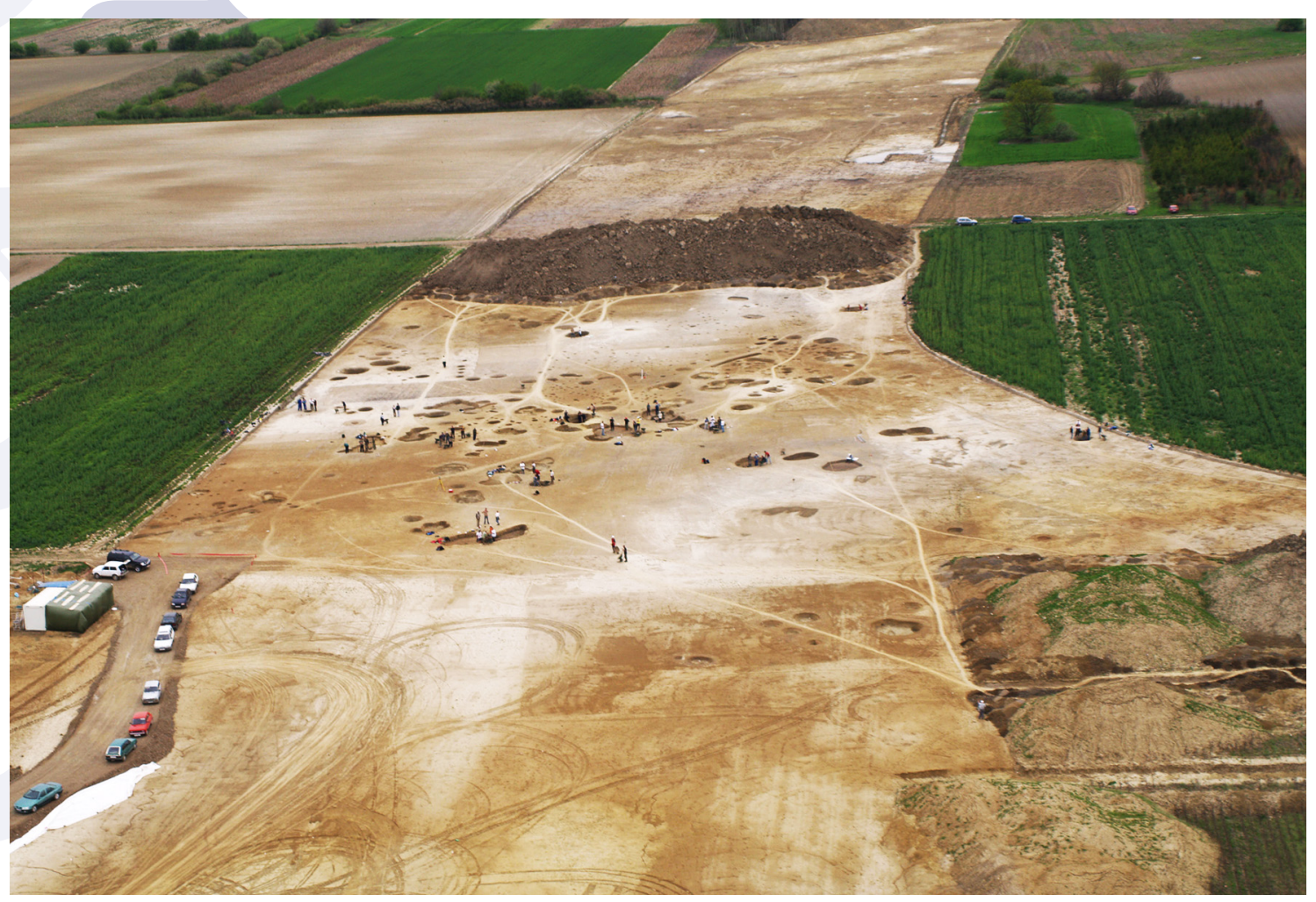

Figure i. Aerial view of the archaeological rescue excavation on the site Josipovac - Verušed (Phototeque, Department of Archaeology, Faculty of Humanities and Social Sciences, University in Zagreb, 2007). 


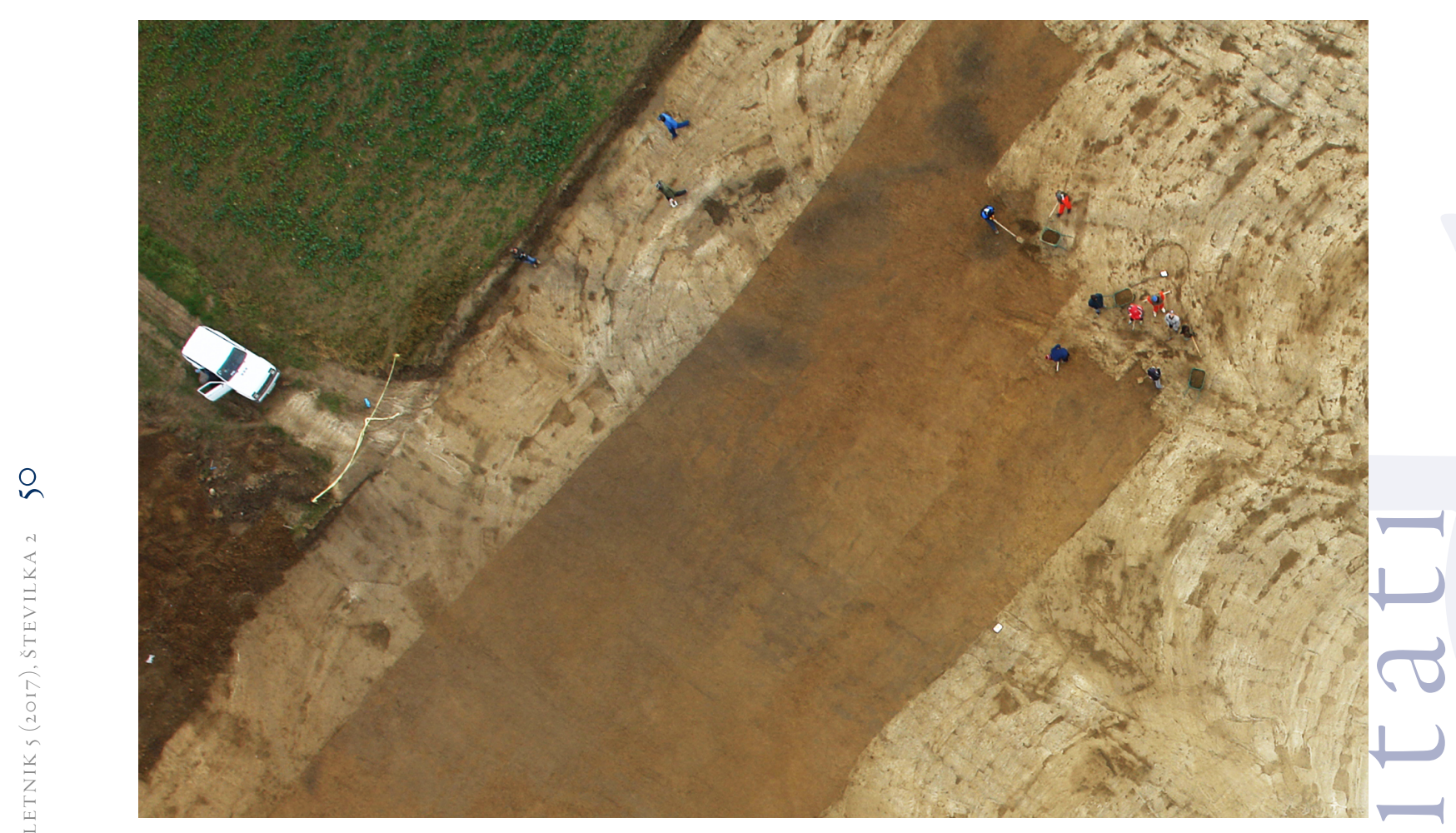

Figure 2. Aerial view of the polished surface of the ground before escavation on the site Josipovac - Verušed (Phototeque, Department of Archaeology, Faculty of Humanities and Social Sciences, University in Zagreb, 2007).

\section{Results}

The described possible finding of a recent age on the site Josipovac - Verušed was treated as a real archaeological, historical layer, since prior the excavation there was no information that could confirm its age. Cleaning began and after removing the topsoil layers at the earth surface, soil with specific characteristics was revealed, such as dark colour, greasy appearance and consistency, affirming it was very probably a burial (Fig 2). This burial was not deep, in fact, it was very shallow and layer contours emerged immediately after removing layers of ploughing (approximately on thirty to forty centimetres of depth). After defining the entire pit on the surface, only a part was sorted out to see its content. Therefore, the grave was not being excavated all at once, first, a smaller probe was made in the part where the best results were calculated. In a small probe that had scarcely $20 \mathrm{~cm}$ in width and about $10 \mathrm{~cm}$ in depth human remains were found. They were a part of a badly preserved shin (tibia), due to the shallowness of the grave. The probe encircled the area near the legs. The entire outline of the dark soil had a north-south orientation and there was no longer any doubt that it was a burial pit. After that, the whole pit was defined so that its entire surface was lowered and the layer of soil slightly removed. A bigger surface of the grave was covered with dark soil and a smaller one with lighter soil or subsoil, which was transferred from the deeper layers to the surface. That lighter layer differed from the real subsoil just in a hardness degree.

After the entire burial pit was defined, its final form was seen as a form of a fairly broad and rectangular grave. This was in contrast to our original thesis that it was an emergency burial. During further cleaning of the grave's surface, and removing of a layer of earth 2 to $3 \mathrm{~cm}$ 
thick, several iron items were found, close to the skeleton, at the level of its legs. There was a tube that looked like a barrel of an automatic firearm, or as a fragment of a firearm used in World War II. So when, after defining skeleton remains, remains of a firearm emerged from the soil, the Ministry of the Interior, the police, had to be informed, because it was obvious that the skeleton belonged to a victim of World War II or the post-war period. Indications for dating the grave at that time were indisputable, due to the typization of armament found in it. The excavation continued according to the archaeological methodology, starting from the legs' position. In archaeological research skeletal remains are cleaned from the feet to the head. According to the preliminary anthropological analysis, the skeleton belonged to a male person aged 30-40 years at the time of death. In its grave, the skeleton was laid on the back and close to it more small metal objects were detected (Fig 3 ).

In the shoulder area, close to the upper part of the chest, a small iron emblem was found. It was quite corroded, yet it still had clear outlines reminiscent of a bird of prey, maybe an eagle. The skeleton was completely cleaned according to archaeological research methods. Metal buttons were detected at several positions close to the skeleton: three at the level of both shoulders, two at the chest level, two on the right humeral bone and six more, almost in line near the spine on both sides, from the suprasternal notch to the waist level (Fig 4). The soil around and close to it was also removed and levelled with the skeleton. Since the grave was shallow, when a ploughing layer of $30 \mathrm{~cm}$ was removed, a very thick layer of about $10-15 \mathrm{~cm}$ for the burial itself remained. The skeleton was very poorly preserved, so it was more like a medieval burial than from the years 194I-1945. Each segment of the work was carefully performed, checking several times so as not to miss anything. Each phase was documented with description, photographs and drawings. A detailed plan and profile (cross-sectional) maps of the skeleton were made before it was removed. In the end, the final image, a photograph of the

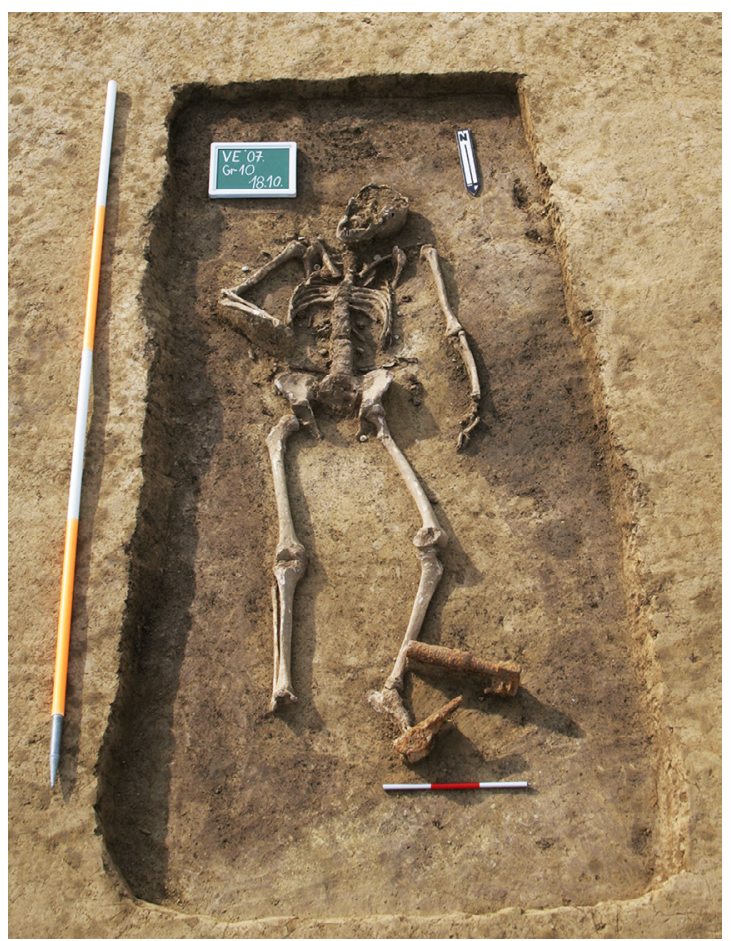

Figure. 3. Grave io- the skeleton of a German soldier in situ (Photo: Krešimir Filipec, 2007).

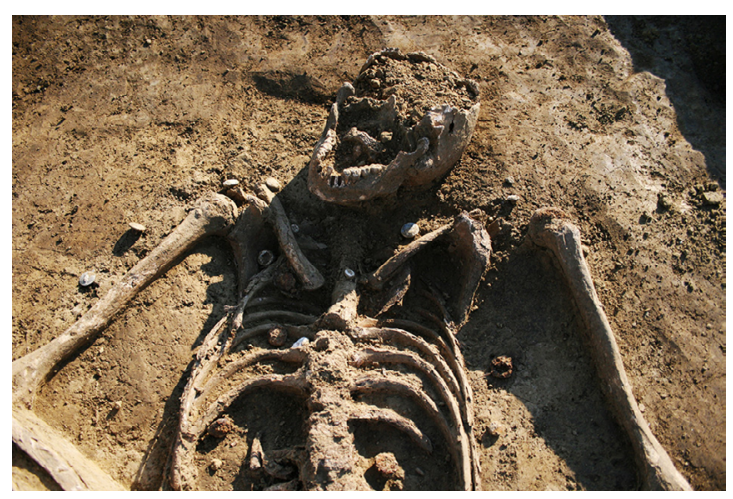

Figure. 4. Grave Io- the upper part of the skeleton of a German soldier in situ (Photo: Krešimir Filipec, 2007).

entire burial pit with the skeleton was enclosed in the documentation. After being stabilized and raised, the skeletal remains were taken to the pathologist of the Department of Pathology and Forensic Medicine (Clinical Hospital Osijek) for further analysis. Afterwards, the excavation, 
or better, cleaning, was continued, because it was obvious that at the bottom of the defined grave new pits emerged as a dark layer - black oily soil, organic residues or maybe humus - which from the upper layers could have reached the lower ones. The first layer was located close to the right leg, the second close to the left hand, and the third around the place where the skull of the deceased person was placed. In the empty pit, close to the bones of the right leg, small metal objects were found, but with no potential for further analysis. A similar composition was found close to the bones of the left hand, the pit was dug to the bottom but no other artefacts were detected; if there was any organic material laid in the pit, it had not been preserved. In the third pit, discovered under and near the skull, immediately after the raising of the skeleton, corroded iron objects were found. Deeper digging revealed firearms' ammunition: about twenty anti-aircraft bullets and twice as many bullets of various calibers for machine guns and rifles. The ammunition was unused, spent shells were not found. Close to the bullets, some organic material was found, remnants of the leather cases for ammunition and parts of a belt. All the ammunition was documented, measured and photographed. As all the ammunition was unused and poten-

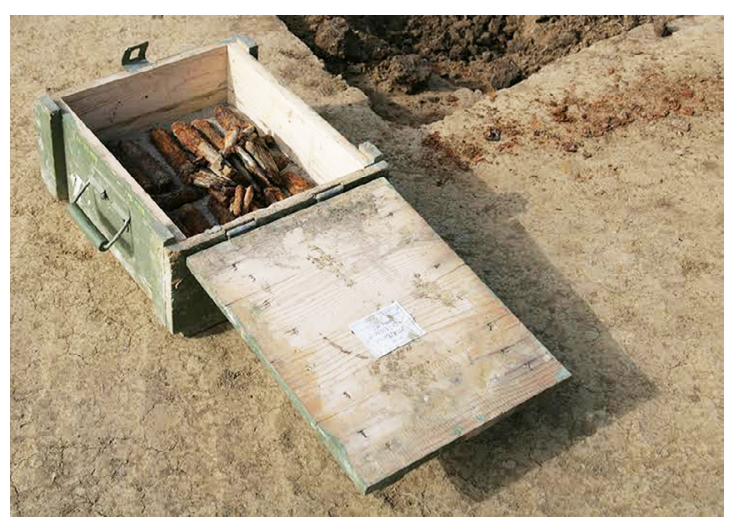

Figure. 5. Storing of ammunition from the burial pit before its safe destruction (Photo: Krešimir Filipec, 2007).

tially very dangerous to the environment, an official pyrotechnist arrived on the archaeological site and destroyed it near the grave (Fig 5). After the third pit was completely emptied, it was possible to come to some conclusions.

\section{Discussion and Conclusion}

The grave was excavated in a field and according to preliminary data the body was placed within during the last century. The burial pit was shallow and it had unusual orientation. Somewhat similar situations were described at other archaeological locations, such as on the site Stari Perkovci - Debela šuma in Brod-Posavina county, but at first glance, this was a slightly different case. In Stari Perkovci - Debela šuma the discovered person was killed and buried in a shallow pit. The pit configuration was quite irregular, and it was clear that digging and burial had been done in haste. ${ }^{4}$ But the burial pit was spacious enough to throw the body into, positioned on its side, and cover it with earth. That case also appertains to the victims of World War II or the post-war period. But there are a few noticeable differences between the two cases. The burial pit from Josipovac - Verušed near Osijek is also located not in the cemetery but in a field, yet its contours show a neat, precise digging work, though indeed shallow. However, this pit is wide and long enough to lay the body on its back in extended position. Metal buttons were detected at several positions close to the skeleton, as it was mentioned before: three at the level of both shoulders, two at the chest level, two on the right humeral bone and six more, almost in line near the spine on both sides, from the suprasternal notch to the waist level. The position of the buttons indicates remains of the short upper part of a military uniform with epaulettes. Also, after further research, a thesis was set about the iron, corroded emblem in the shape of an eagle. This emblem was most probably positioned on the cap or was a part of the military uniform. The burial was preliminarily defined as a burial of an unknown soldier. The person who buried his dead body first dug a grave with

Krešimir Filipec and Marija Šiša-Vivek, „Report on the archaeological site Debela šuma," Hrvatski arbeološki godišnjak no. 3 (2006): 69$7 \mathrm{I}$. 
three smaller pits inside, into which he laid ammunition, parts of the holster with bullets, and any other object of organic origin. The organic material, including soft tissues of the body, decomposed very quickly, not only because of the shallow burial and the effects of the weather conditions but also because of the high acidity of the soil. The gravedigger put ammunition and organic material in the pit, which had to be collected from the wider area, obviously after a battle. Over it, he laid the dead body and next to him the fragments of destroyed weapons. After the archaeological excavation and research, this is beyond dispute. All phases of the work were documented and photographed so that nothing misses. The skeletal remains of the deceased, the weapon components, the metal buttons and the corroded emblem were stored under the protocol for possible subsequent analysis that could get more information about the person and the circumstances of his burial. On this archaeological site, no similar burial pits were found. However, about a thousand meters eastward, towards Osijek, a military bunker from World War II is still preserved. It was an assumption that maybe the death of the buried person was related to broader events in the area at that time. With subsequently conducted archival research we found out what probably happened in that marginal area of the town of Osijek, west of Josipovac. The theory was set that it was the grave of a soldier from World War II. For a moment, consider the corroded iron emblem with, most probably, depiction of an eagle. In the archive files, it was mentioned that the II $^{\text {th }}$ German Air Force Division was situated in Osijek and participated in the battles for the city. With advancing of the People's Liberation Army and Partisan Detachments of Yugoslavia toward Osijek, in the last days of World War II, a combat began in which many soldiers were killed. On the photograph published in the book of Petrov, in descriptions and on additional photographs, captured German soldiers in the underwear can be seen. ${ }^{5}$ Some-

Marinko Petrov, Pakao na Dravi Belišce 1944-1945 Bistrinci (Bački Petrovac: Mesno udružnje boraca NOR-a Belišće, 1979), I 42-1 47. how the situation could be similar to the case of Josipovac - Verušed: a soldier that was killed in a battle, or executed after it, and then buried by a villager in his plough-field or along its edge.

As mentioned earlier, at the very beginning, the orientation of the grave was North-South. Such grave orientation follows the orientation of the plough-fields in that area. It indicates that the soldier was buried in a part of the field not used for cultivation, to avoid unpleasant situations. It is quite possible that the villager who burried him was an owner of that plough-field where the battle occurred. Afterwards, he might have collected all explosive and unexploded ammunition scattered around and buried them beneath the killed soldier. Unfortunately, it was not possible to do any further research, a survey, about this case with the locals, because the majority of the inhabitants of the village Josipovac were expelled after the end of World War II. Namely, in Josipovac had lived members of the German minority in Slavonia. These are assumptions after the archaeological excavation and research were done.

The described methods of research belong to archaeology, from the preparation of a site to the fieldwork. But in this particular case some very important phases of forensic archaeology are missing, such as the area location, the site location and the confirmation, because this grave was found by chance on an archaeological site. These phases include not only location and confirmation but also a determination of its nature. Both archaeological sites and forensic crime scenes, f.e. mass grave's vicinity, contain valuable evidence like fragments of clothing, various objects or personal items.

While in archaeological field research the use of modern methods and techniques depends largely on financial possibilities, in forensics they are a must. Development of nonintrusive or non-destructive tools gives a possibility to see through the layers of the ground, without destroying the site. In the area and site location, forensic archaeologists use several tools like area imagery taken by the aerial reconnais- 
sance platforms. From the air, it is possible to explore anomalies in the ground, such as the disturbed land of mass grave trenches. So, instead of described helium balloons with a platform in the case of the unknown soldier from Josipovac, it is possible to use drones. On the site, soil geochemistry could be analyzed by the use of a handheld X-ray fluorescence spectrometer (XRF). It detects traces of human and animal activities (like faeces) in the ground measuring the elemental composition of the soil or an artefact/evidence. On the site, it is possible to determine the extent of an activity or an object using radar pulses to image the ground, with a ground penetrating radar (GPR) and other geophysical techniques. Tools for the shallow geophysics on the site measure ground resistivity and thus can reveal buried structures just like the electrical resistant survey. ${ }^{6}$ Other alternative techniques are time-lapse resistivity and remote sensing. The last one includes several very popular technologies, like aerial photographs, ultraviolet (UV) and infrared (IR) photography, satellite and hyperspectral imagery, light detection and ranging (LiDAR). LiDAR in a fraction of time gives detailed ${ }_{3} \mathrm{D}$ maps of the site surface and can easily locate clandestine and mass graves.

Documentation, as it was explained in the case, is of great importance during this work. Forensic forms are even more detailed: about preservation degree, taphonomic processes (a body or a part of a body, clothes), other evidence on human remains (tattoos, ligatures, a blindfold, position). This is called in situ evidence. The excavated earth has to be sifted, as in the case of material from the burial pit of the unknown soldier from Josipovac. After the excavation of the skeleton in the case, the profile and the floor of the grave was checked for possible trace evidence - in forensics these are often strands of hair, fibres, paint or fingerprints. The end of the excavation means that all the evidence are recorded, photographed, and put in an appropriate stor-

6 Lewis Somers, „Resistivity Survey," in Remote Sensing in Archaeology, ed. Jay K. Johnson (Tuscaloosa: The University of Alabama Press, 2006), 109-131; Anthony Clark, Seeing Beneath the Soil: Prospection Methods in Archaeology (London: B.T. Batsford; 1990). age. Upon the completion of the excavation, the grave pit is refilled and the place is left safe. All equipment has to be cleaned under supervision, and cleaning should be documented as a standard, to ensure that cross-site contamination cannot occur.

Differences in archaeology and forensic archaeology may be considerable, but basic methods of the field research do not differ. In forensic archaeology, especially when it embraces the study of mass graves, the term 'exhumation' is used, not just like a medico-legal term. The term 'exhumation' accentuates special attention and emphasis given to human remains, because of their identification and later, returning to the families. This does not mean that attention is not given to the context, in the sense of contextual evidence that may be relevant to the case. During the field work on individual or mass graves on archaeological sites, the term 'excavation' is used. The archaeological fieldwork has more humanistic approach and gives equal at- $\downarrow$ tention to the human remains and the context. The interpretation of the results will be thus somewhat different than in forensics. Now, the distinction between forensic excavation and forensic exhumation is clear as the difference in volume results. As archaeologists are dealing with vast time spans, it is important to detect chronology of a site, how old the findings are. Together with research of a necropolis, it is very important to reconstruct possible settlements of that precise period, and also its environmental history. Finally, one of the major questions is how people were functioning in that particular time, what can be told about their life. The dating of recent mass or individual graves also partially belongs to the field of archaeology. Since the best-known method for determining absolute age in archaeology - radiocarbon dating ${ }^{14} \mathrm{C}$ - will not give adequate results for recent findings, the classical archaeological methods of relative dating are used. Objects described in the case of an unknown soldier, such as fragments

Melissa Connor and Douglas D. Scott, "Paradigms and Perpetrators," Historical Archaeology 35, no. I. (2001): I-6. 
of clothing, emblems, arms and ammunition, help to locate this finding in a specific time period. Indeed, a number of such findings can narrow time span dating. Development of forensic taphonomy in the sense of burial environment analysis, f. e. soil analysis, opens up possibilities for a more precise dating of findings, a determination of the post-burial interval and sometimes also of the post-mortem interval. In general, different biological markers like botanical remains can be used in determination of the period between the time of deposition in the burial site and the time of recovery. ${ }^{8} \mathrm{~A}$ more specific and a very potent tool to establish the burial time in extended post-mortem period, but also to reveal possible clandestine graves, is the use of the postputrefaction fungi.' Unfortunately, in the case of an unknown soldier from Josipovac soil samples were not taken from his grave for analysis. Such an analysis could give us the information in which season of the year the body was placed in the burial pit.

As in the case of the unknown soldier, there is an intertwining of archaeology and domain of police powers when it becomes forensic archaeology. In archaeology, it is a moment when anthropological osteological remains from World War II or younger period are revealed on a site. Then the police has to be informed about the finding, which stays in a domain of forensic medicine. Also, if the police specialists find human remains and assume they are not recent, they often call archaeologists for help to resolve

8 Shari L. Forbes, „Potential Determinants of Postmortem and Postburial Interval of Buried Remains," in Soil Analysis in Forensic Taphonomy, eds. Mark Tibbett and David O. Carter (Boca Raton: CRC Press, 2008), 225-2; Heather C. Miller, Cheng-Lung Lee, Wen-Yu Lin, Henry C. Lee and Timothy M. Palmbach, „Forensic Botany: Using Plant Evidence to Aid in Forensic Death Investigation," Croatian Medical Journal 46, no. 4 (2005): 606-612.

9 David L. Hawksworth and Patricia E.J. Wiltshire, „Forensic mycology: the use of fungi in criminal investigations," Forensic Science International 206, no. I-3 (201 I): I-1 I; Shari L. Forbes, „Potential Determinants of Postmortem and Postburial Interval of Buried Remains," in Soil Analysis in Forensic Taphonomy, eds. Mark Tibbett and David O. Carter (Boca Raton: CRC Press, 2008), 225-246; Masahito Hitosugi, Kiyoshi Ishii, Takashi Yaguchi, Yuichi Chigusa, Akira Kurosu, Masahito Kido, Toshiaki Nagai and Shogo Tokudome, „Fungi can be a useful forensic tool," Legal Medicine 8, no. 4. (2006): 240-242. the dilemma. As it was said before, for archaeologists, the findings in the graves are in general more important than the skeleton and greater importance is given to them. Archaeologists admit that if they were to choose between saving an artefact or skeleton remains, they would choose the artefact. Finally, if you ask an archaeologist if there is a clearly written ethical and bioethical code that must be respected during the research, he will recognize there is not. Younger archaeologists learn from the older ones, and from the elders, they also adopt unwritten ethical rules important in their work. They are aware that excavation irreversibly destroys the possibility of another approach to the research, and that often no one can refute their interpretation because the ground has been already excavated, destroyed for further research. The same can be said for forensic archaeology - an exhumation will forever destroy the site or the crime scene; it is thus important to work according to specific protocols, methods, techniques and available technologies. The forensic excavation follows all the rules of the traditional archaeological excavation, but all steps are elaborated and elevated on a higher level with protocols and standard operating procedures (SOP's). ${ }^{1 \circ}$ This helps in resolving every day and also more unusual ethical dilemmas during the work.

Everybody claims that there should not be double standards, that skeletal remains from any historical period should be treated in the same way, with the same respect, as those from the recent wars. But then the awareness of the whole society should be at a significantly higher level. It is clear that the dead can no longer be hurt but there are still strong reasons for treating them with respect, respect for the individual.

What archaeology tells us about the future of the skeletal burials? The calculation is simple. On average, one hundred million peo-

\footnotetext{
Io Anderson Auson, Margaret Cox, Ambika Flavel, Ian Hanson, Michael Hedley, Joanna Laver, Auson Perman, Mark Viner and Richard Wright, „Protocols for the investigation of mass graves" in The Scientific Investigation of Mass Graves: Towards Protocols and Standard Operating Procedures, eds.Margaret Cox, Ambika Flavel, Ian Hanson, Joanna Laver and Roland Wessling (Cambridge: Cambridge University Press, 2008) 39-102.
} 
ple are born annually and forty million dies. If those forty million were buried in a necropolis, in a classic graveyard with skeletal burials, they would take up an area of $20 \mathrm{~km}^{2}$. One day, not in the distant future, this will become a huge problem. Will we throw our dead into the sea, or fertilize the soil with them, will we burn them?

What yesterday was ethics, today may no longer be. The rule about preserving, what we must and what we want to preserve, and our choice will represent our civilization. Whatever we thought yesterday we would preserve, if possible all of it, today has a completely different dimension. Where are the areas in which we will preserve all that? In the whirlwind of events in the recent years, more and more raises the question of how to survive, how to provide enough space and food for all, but also how to preserve everything of value? Archaeology will offer an answer based on the long history of human experience.

\section{Povzetek}

Predstavljeno delo raziskuje, do kakšne mere obstaja razlika v raziskovalni metodologiji in tehniki arheologije in forenzične arheologije. Iz zelo osnovnega razlikovanja med „izkopavanjem grobov", pojmom, ki je bliže arheološkemu smislu in „ekshumacijo človeških ostankov", tesno povezano s forenzično arheologijo, do novih modelov, ki bi lahko v prihodnosti omogočili boljšo kakovost raziskav in preiskav. $V$ zadnjih tridesetih letih so bili kot del multidisciplinarnih forenzičnih strokovnih ekip povabljeni arheologi, še posebej ob raziskavah skrivnih grobov in množičnih grobišč iz nedavnih vojn, ko je šlo za vprašanja človekovih pravic. Dobra študija prekrivanja forenzičnih in arheoloških primerov je skrivni grob neznanega vojaka iz druge svetovne vojne iz arheološkega najdišča Josipovac - Verušed pri Osijeku (Slavonija, Hrvaška). Odkrit je bil med zaščitnimi arheološkimi izkopavanji, leta 2007, na trasi avtoceste (A 5) Beli Manastir - Osijek. Najdba je bila na tem arheološkem najdišču nepričakovana, zato so bili vsi standardni postopki izvedeni že pred izkopom. Obravnavana je bila kot arheološki kontekst, saj pred izkopavanji ni bilo informacij, ki bi lahko potrdile starost, obdobje ali status pokojnika. Ko so se po opredelitvi kostnih ostankov v raziskanem kontekstu pojavili ostanki strelnega orožja, pa so se glede na to razvrstili in analizirali tudi drugi predmeti iz groba, kar je pomagalo pri kronološki, kulturni in individualni identifikaciji umrle osebe. Pomen poudarjanja konteksta je zelo pomemben, saj je omogočil razvrstitev ugotovitev v forenzični okvir. Pomembno je tudi izpostaviti razpravo o etičnih vprašanjih, saj so človeški ostanki lahko izhajajo iz arheoloških kontekstov ali pa so del uradnega postopka, ki lahko prinese pomembne dokaze za sodišče.

\section{Summary}

The present work explores to which extent the difference between research methodology and techniques of archaeology and forensic archaeology exists. From the very basic distinction between "graves excavation", a term closer to archaeological sense, and "exhumation of human remains”, closely related to forensic archaeology, to the new models that could give better quality of both research and investigations in the future. During the last thirty years, archaeologists have been called, as part of the multidisciplinary forensic expert teams in human rights cases, to investigate clandestine graves and especially mass graves from recent wars. A good case study of overlapping forensic and archaeological cases is the clandestine grave of an unknown soldier from the World War II, from the archaeological site Josipovac - Verušed near Osijek (Slavonia, Croatia). The grave was revealed during an archaeological rescue excavation in 2007 , on the route of the highway A 5 , Beli Manastir - Osijek. This finding was unexpected for an archaeological site, so all standard procedures that precede the excavation had already been made. It was treated as a real archaeological, historical layer because before excavation, there was no information that could confirm its age, period or status. So when, after defining the skeleton remains, remains of a firearm emerged from the soil, classifying and analyzing the objects from the grave helped to give chronological, cultural and individual identifiers of the deceased person. The importance of giving emphasis to the context, which enabled the classification of findings in the forensic framework, was accentuated. It is crucial to mention and discuss the ethical issues of whether the human remains are part of an archaeological period, or they are part of a case that could provide evidence for the court. 


\section{Bibliography}

Clark, Anthony. Seeing Beneath the Soil: Prospection Methods in Archaeology. London: B.T. Batsford, 1990.

Connor, Melissa and Douglas D. Scott. "Paradigms and Perpetrators." Historical Archaeology 35, no. 1 (2001): 1-6.

Cox, Margaret. Ambika Flavel, Ian Hanson, Joanna Laver and Roland Wessling. The Scientific Investigation of Mass Graves: Towards Protocols and Standard Operating Procedures. Cambridge: Cambridge University Press, 2008.

Filipec, Krešimir and Marija Šš̌a-Vivek. "Report on the archaeological site Debela suma." Hrvatski arheološki godišnjak no. 3 (2006): 69-71.

Forbes, Shari L., ,Potential Determinants of Postmortem and Postburial Interval of Buried Remains." In Soil Analysis in Forensic Taphonomy, eds. Mark Tibbett and David O. Carter, 225-246. Boca Raton: CRC Press, 2008.

Haglund, William D. "Archaeology and Forensic Death Investigations." Historical Archaeology 35, no. 1 (2001): 26-34.

Hawksworth, David L., and Patricia E.J. Wiltshire. „Forensic mycology: the use of fungi in criminal investigations." Forensic Science International 206, no. I-3 (20II): I-II.

Hitosugi, Masahito, Kiyoshi Ishii, Takashi Yaguchi, Yuichi Chigusa, Akira Kurosu, Masahito Kido, Toshiaki Nagai and Shogo Tokudome. „Fungi can be a useful forensic tool." Legal Medicine 8, no. 4. (2006): 240242.

Miller, Heather C., Cheng-Lung Lee, WenYu Lin, Henry C. Lee and Timothy M. Palmbach. „Forensic Botany: Using Plant Evidence to Aid in Forensic Death Investigation." Croatian Medical Journal 46, no. 4 (2005): 606-612.
Petrov, Marinko. Pakao na Dravi Belišće 19441945 Bistrinci. Bački Petrovac: Mesno udružnje boraca NOR-a Belišće, 1979.

Scott, Douglas D., and Melissa Connor. "The Role and Future of Archaeology in Forensic Science." Historical Archaeology 35, no. 1 (2001): 101-04.

Somers, Lewis. „Resistivity Survey.“ In Remote Sensing in Archaeology, ed. Jay K. Johnson, I09-I3I. Tuscaloosa: The University of Alabama Press, 2006.

Tibbett, Mark and David O. Carter, eds. Soil Analysis in Forensic Taphonomy. Boca Raton: CRC Press; 2008.

\section{Abbreviations}

Hist Archaeol.=Historical Archaeology Croat Med J = Croatian Medical Journal Forensic Sci It = Forensic Science International Legal Med $=$ Legal Medicine 
-

r

$\downarrow$

G

1

-

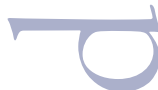

( )

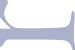

(U)

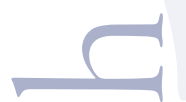




\title{
Neyidljiva dugovečnost u arheološkom kontekstu
}

\author{
Zorana Dimković
}

Nevidnost starejših v arheološkem kontekstu je bila večinoma posledica nezmožnosti njihove identifikacije s klasično skeletno paleodemografsko analizo. Maksimalno trajanje življenja je bilo pogosto enako kot zelo nizka pričakovana življenjska doba ob rojstvu. Slednja se je enačila z dolgoživostjo, čeprav ni odvisna zgolj od biološke kapacitete za dolgo življenje, temveč tudi od okoljskih dejavnikov in režima umrljivosti. Namen tega prispevka je razjasniti probleme zanikanja dolgoživosti v arheologiji, s kratkim vpogledom v kvantifikatorje človeške dolgoživosti in v način, kako so klasične metode za določanje starosti okostja odraslih posameznikov zanikale doživetje globoke starosti.

Ključne besede: pričakovana življenjska doba, dolgoživost, klasična paleodemografska analiza

Older people have been very much ignored in archaeological contexts and part of the reason for that has been the inability to identify them with the methods of classic paleodemographic analysis. The maximum life span often equated with the low life expectancy at birth. The latter equated itself with longevity, although it does not depend solely on biological capacities, but also environmental factors and mortality regimes. The aim of this paper is to elucidate the problems of denying older people in archeology, through a brief insight into the quantifiers of human longevity, and the way in which the classic methods for determining the age of skeletons of adult individuals underestimate the experience of a deep age.

Keywords: life expectancy, longevity, classic paleodemographic analysis

7 ermin paleodemografija, nasuprot istorijskoj demografiji, se koristio za demografsku analizu na osnovu fizičko-antropoloških ostataka u okviru fizičke antropologije, pa se u literaturi ustalio izraz skeletna paleodemografija. ${ }^{\mathrm{I}}$ Zapravo, radi se o širem pojmu koji se odnosi na proučavanje veličine i strukture drevnih populacija te dinamike promene tih parametara kroz prostor i vreme, kako na osnovu skeletnog materijala, tako i na osnovu materijalne kulture. Stoga je danas paleodemografija sinonim za arheološku demografiju - demografsko

György Acsádi and János Nemeskéri, History of Human Life Span and Mortality (Budapest: Akadémiai Kiado, 1970), 51-7. proučavanje ljudi iz prošlosti na osnovu arheološkog materijala. ${ }^{2}$

Demografske karakteristike populacije su: njena veličina i struktura, stope migracija, fertilitet i natalitet, te mortalitet. Potonji je u direktnoj vezi sa dugovečnošću, a definiše ga broj umrlih podeljen veličinom populacije $u$ jedinici vremena. ${ }^{3}$ Čitanjem paleodemografskih skeletnih zbirki, u osnovi se razlikuju dva režima mortaliteta:

2 Francesco Mallegni, "Paleoantropologija," u Arheološki rječnik, ur. Daniele Manacorda i Ricardo Francovich (Zagreb: Sandorf, 2014), 500.; Марко Порчић, Палеодемографија: критички преглед теорије, метода и истраживата (БеограА: Универзитет у Београду, $А$ абораторија за биоархеологију, 2016) 7.

Andrew Chamberlain, Demography in Archaeology (Cambridge: Cambridge University Press, 2006), 2, 15-44. 
atricioni (ili normalni) i katastrofični. Ovaj drugi se odnosi na svako drastično odstupanje od uobičajenog, atricionog mortaliteta. Tada starosni profil populacije mrtvih podseća na starosni profil populacije živih, što se dešava tokom oružanih sukoba, genocida, prirodnih katastrofa i visoko zaraznih epidemija. Kad je o polovima reč, poslednjih dvestotinak godina, muškarci imaju veće stope mortaliteta od žena, tj. u proseku kraće žive od žena, dok je tokom celog preindustrijskog perioda bilo obrnuto, odnosno žene su u proseku imale kraći životni vek, zbog velike smrtnosti pri porođaju. ${ }^{4}$

U vezi očekivanog životnog veka u prošlosti, često se sreće podatak da je onaj ko je imao 35 godina u srednjem veku ili u praistoriji bio star. Dva su glavna razloga ovakvom potcenjivanju dugovečnosti: pogrešna interpretacija očekivanog životnog veka i pristrasnosti ugrađene u sam metod određivanja starosti putem klasične ${ }^{5}$ paleodemogradske analize skeletnog materijala.

\section{Kvantifikatori dugovečnosti:}

\section{očekivani životni vek pri rođenju}

\section{i prosečno maksimalno trajanje života}

Parametri, na osnovu kojih je najčešće vršena predikcija dužine života, dugovečnosti (longevity), su: očekivani životni vek pri rođenju (life expectancy) i prosečno maksimalno trajanje života (lifespan). Prvo je opšta mera mortaliteta kao aritmetička sredina, koja uzima u obzir smrtnost u svim starosnim kategorijama, tj. meri centar raspona varijacije, dok je druga prosek gornjih ekstrema tog raspona. Pošto starosna distribucija umrlih često pokazuje bimodalnu distribuciju u populaciji, modalna tj. najčešća dosegnuta dužina života, se može znatno razlikovati od prosečnog očekivanog životnog veka.

4 Chamberlain, Demography in Archaeology, 69-80.; Порчић, Палеодемографија: критички преглед теорије, метода и истраживата, 106, 154 .

5 Odrednica "klasična" je upotrebljena, da bi se napravila razlika u odnosu na metodološke promene, koje su započele početkom ovog stoleća i koje su formulisane tzv. Manifestom iz Rostoka, gde su izloženi temelji savremene skeletne paleodemografije (Порчић, Палеодемографија: критички преглед теорије, метода и истраживата, I21.).

6 Chamberlain, Demography in Archaeology, 52-4.
Očekivani životni vek je istovremeno i pokazatelj mortaliteta, jer predviđa događaj smrti. Za praistorijske zajednice taj prosek često iznosi oko tridesetak godina. ${ }^{7}$ Međutim, da li to znači da su ljudi u prošlosti umirali već u trećoj deceniji? I da i ne: da, u smislu da se prosečno toliko živelo, gledano u odnosu na sve individue, koje su rođene u toj populaciji; ne, zato što je smrtnost beba bila ogromna, a ona ulazi u taj prosek. Naime, smrtnost dece od o do I godine je bila čak do 50\%. U stvarnosti, onaj ko preživi tu prvu godinu života je živeo daleko duže, a slično se odnosi i na preživljavanje do adolescentnog doba. Takođe, u pisanim izvorima (epitafi, hronike, popisi, registri trošarina, ugovori, župni arhivi, dela istoričara), su potvrđene daleko starije individue $\mathrm{i}$ istina je daleko od toga da niko u prošlosti nije živeo posle pedesete godine. ${ }^{8}$ Kao primer se može navesti, godinama starosti uslovljena, hijerarhijska lestvica po kojoj su Rimljani mogli napredovati u političkoj karijeri (cursus honorum).

Nedavno je, u sklopu predstavljanja monografije $^{\text {Io }}$ o rimskim natpisima Celeje (Celea), autorka Visočnik govorila o značaju epigrafike kao samostalne discipline. Jedna od najčešćih skraćenica, koju srećemo tipično na nadgrobnicima je an(norum). Govori o tome, koliko je neko bio star u trenutku smrti, pri čemu pronalazimo veću preciznost pri deci, ali i vojnicima, za koje je bilo standardno da ispune 25 godina vojne službe. Epigrafska građa iz antičkog Celja svedoči o veteranima i članovima njihovih porodica, starosti od 50 godina do čak Ioo godina, ${ }^{\text {II }}$ sa primet-

$7 \quad$ Za praistorijske, istorijske i savremene preindustrijske populacije ocene očekivanog životnog veka pri rođenju kreću se izmedu 20 i 40 godina, dok je očekivani životni vek u postindustrijskim društvima iznad 70 godina, a u najrazvijenim zemljama oko 80 i više godina (Порчић, Палеодемографија: критички преглед теорије, метода и истраживать, 103.).

8 Mallegni, "Paleoantropologija," 500.

9 Mary Harlow and Ray Laurence, Growing Up and Growing Old in Ancient Rome (London: Routledge, 2002), 104-16.

Io Julijana Visočnik, France M. Dolinar, Irena Lazar and Mihai Popescu, The Roman inscriptions from Celeia and its ager, trans. Maja Sužnik (Celje: Celjska Mohorjeva družba, 2017).

I Od dvadeset i jednog epitafa o vojnicima i njihovim porodicama iz Celeje, na osam se pojavljuju informacije o ljudima od 50 i više godina u trenutku smrti: Lucije Brecije Publije, iz Verone, veteran Osme legije avguste, star 70 godina i Magiona, Verulova kćerka, stara 75 godina; veteran Gaj Junije Isej, bivši dekurion Prve ale 
nom praksom zaokruživanja na bar pet godina, što ne iznenađuje, s obzirom na to da i danas postoje, bar kad je o Balkanu reč, starije osobe koje ne pamte tačnu godinu rođenja. Nedostatak preciznih informacija o godini rođenja, može da se očekuje i u bilo kojoj drugoj kulturi sa različitim konceptom vremena. Opet, kad je o rimskom razdoblju reč, sem velikog broja nadgrobnika sa preciznim podacima o godinama smrti dece, često se pojavljuju votivni natpisi posvećeni dojiljama i dadiljama. Takav je slučaj u antičkoj Petovioni (Poetovio), današnjem Ptuju, sa oltarima podignutim božanskim Nutricama. Radi se o lokalnom verovanju, koje je nastavilo da živi nakon procesa romanizacije, a dedikanti su oslovljeni kako rimskim, tako i keltskim imenima. Likovni prikaz svedoči o važnosti žena koje su brinule o bebama, ali i o malo starijoj deci uzrasta od 5 do 7 godina. Važnost dojilja je u skladu sa visokom smrtnošću dece, prvenstveno pri porođaju, tokom celog preindustrijskog perioda, pa i u keltsko-rimskom svetu. Uzimajući u obzir, na jednoj strani, visoku smrtnost dece, a na drugoj - epigrafske nalaze smrti odraslih osoba od po 85, 90 i roo godina - moguće je objasniti prosečnu starost u antici kao vrednost izmedu 35 i 40 godina, ali time se ne ograničava najstariji deo populacije samo na početak pete decenije. Dovoljno je samo da pomislimo na najslavnije $\mathrm{Ri}$ mljane $\mathrm{u}$ trećem dobu: Cezar je imao 56 godina kada je ubijen, Ciceron 63, a Oktavijan Avgust, koji je, premda krhkog zdravlja, najverovatnije preminuo tek u svojoj 77. godini. ${ }^{13}$ Takođe, ste-

Komagenov, star 60 godina; Kvint Enije Apolonije, star 60 godina i Valerija Maksimila, stara 50 godina; Avrelije Gajan, sirijske narodnosti, dekurion italske legije, star so godina; Gaj Vibije Sabin, veteran Pete makedonske legije, star 65 godina; Tercijeva kćerka Mogija, stara 50 godina; Sakronije Verin, veteran Druge italske legije, star so godina; veteran Vibije Sekundus, star 100 godina i Cerula, stara 9o godina (Julijana Visočnik in Maja Sužnik, "Vojaški napisi iz Celeje in njene okolice," Arheološki vestnik 59 (2008): 326-35, http://www.dlib.si/?URN=URN:NBN:SI:doc-WSQU 4 VXK (pristupljeno 7. I. 2018.)).

I2 Marjeta Šašel Kos, "Nutrices: the most popular goddesses at Poetovio," in Zentralortund Tempelberg. Siedlungs-und Kultentwicklung am Frauenberg bei Leibnitz im Vergleich, Akten des Kolloquiums im Schloss Seggau am 4. und 5. Mai 20I5, hrsg. Manfred Lehner und Bernhard Schrettle (Wien: Phoibos Verlag, 2016), 167-74.

13 Harlow and Laurence, Growing Up and Growing Old in Ancient Rome, I17-31. reotip je da su i u srednjovekovnoj i renesansnoj Evropi ljudi u petoj deceniji smatrani starcima, a elita imala ekskluzivno pravo na dugovečnost. Još je devedesetih prošlog veka, istoričarka Šahar prikupila niz povesnih dokaza, koji ukazuju da je ta pogrešna percepcija delimično utemeljena na konfuziji između pojmova maksimalnog životnog veka i prosečnog očekivanog životnog veka na rođenju, kao i na nekritičkom čitanju autobiografskih tekstova. Autorka daje argumente da je u srednjem veku, kao i u moderno doba, fizička sposobnost postajala ograničena, u proseku, u sedmoj deceniji života. ${ }^{14} \mathrm{Ne}$ postoje, dakle, pisani izvori o tome, da je maksimalni životni vek bio smanjen u ranijim istorijskim razdobljima. Ova tvrdnja se potkrepljuje i recentnim bioarheološkim istraživanjima starosti na osnovu trošenja zuba, na primer, skeletne populacije iz ranosrednjovekovne Engleske, gde su potvrđene individue starosti preko 75 godina.

U okviru tzv. etnografske demografije, studije populacija lovaca i sakupljača, sa umerenom ili visokom stopom mortaliteta, pokazuju da pojedinci u ovim populacijama preživljavaju sedamdesete ili osamdesete godine. U svim etnografski zabeleženim preindustrijskim zajednicama bilo je veoma starih ljudi, a modalna starost u kojoj odrasli pripadnici preindustrijskih zajednica umiru, prema kroskulturnim podacima o lovcima-sakupljačima, je 72 godine, dok se očekivani životni vek za doživljenu 45. godinu, kod lovaca-sakupljača kreće od 14 do 24 godina, što znači između 59 i 69 godina. ${ }^{16}$ Dostupni podaci za lovce-sakupljače mogu se porediti sa tzv. modelskim životnim tablicama, koje predstavljaju teorijske strukture populacija, dizajnirane tako da obuhvate široki spektar realnog života sedentarnih zajednica. Takva poređenja su

I 4 Shulamith Shahar, Growing Old in the Middle Ages: 'Winter Clothes Us in Shadow and Pain'(London: Taylor \& Francis, 2002), I2-35.

is Christine Cave and Marc Oxenham, "Identification of the archaeological 'invisible elderly': An approach illustrated with an Anglo-Saxon example," International Journal of Osteoarchaeology 26, (August 2014): 163-75, doi: 10.1002/oa.2408.

16 Gurven, Michael, and Hillard Kaplan, "Longevity among Hunter-Gatherers: A Cross-Cultural Examination," Population and Development Review 33 (Jun 2007): 321-65. http://www.jstor.org/stable/25434609 (pristupljeno 21. 4. 2018.). 

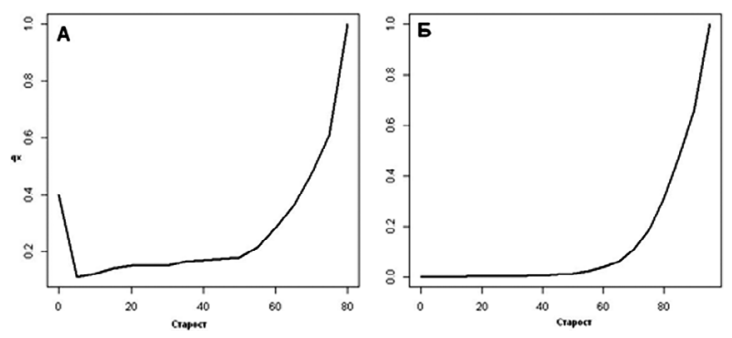

Slika i. Shema obrasca starosno specifične verovatnoće umiranja kod pre- (A) i industrijskih (Б) populacija. $\mathrm{Na}$ $\mathrm{x}$-osi je starost, a na y-osi verovatnoća umiranja (Izvor: Порчић, Палеодемографија: критички преглед теорије, метода и истраживана, слика 42, Iо4.).

pokazala, da demografski profili mobilnih lovaca i nomadskih zajednica podsećaju na one populacije koje pokazuju izrazitiju sedentarnost. U stvari, najupadljivije demografske razlike nastaju tek sa razvojem medicine, u industrijskim i postindustrijskim društvima. Na grafikonima (Slika I) su dati tipični profili mortaliteta preindustrijskih i industrijskih zajednica, gde kod preindustrijskih imamo značajno više umrlih u najmlađim starosnim kategorijama, zbog već pomenute velike smrtnosti dece u preindustrijskoj eri. Verovatnoća umiranja je visoka u prvom starosnom intervalu (od 20 do $40 \%$ ), zatim naglo pada i ostaje manje-više konstantna do pete decenije života, kada počinje da raste, dostižući svoj maksimum između 70 i 80 godina, čime se dobija krivulja koja delimično podseća na latinično slovo " $U$ ”. ${ }^{18} \mathrm{Kad}$ je reč o industrijskim zajednicama, smrtnost beba je drastično smanjena (na manje od i\%) usled razvoja akušerstva, dok je obrazac od 40 godina pa naviše, u opštim crtama sličan preindustrijskom, tako da kriva ima oblik slova "J". Budući da očekivani životni vek pri rođenju uzima u obzir i smrtnost u prvoj godini života, konačni ishod je drastična razlika između pre- i industrijskih zajednica u očekivanom životnom veku: između 20 i 40 godina kod pre- i preko 60 godina kod industrijskih. ${ }^{19}$

\footnotetext{
I7 Chamberlain, Demography in Archaeology, I I.

I8 Acsádi and Nemeskéri, History of Human Life Span and Mortality, 26-8

19 Порчић, Палеодемографија: критички преглед теорије, метода и истраживата, 104.
}

Što se tiče maksimalnog trajanja životnog veka, doprinos razvoja medicine u poslednja dva veka, ogleda se u smanjenju mortaliteta svih starosnih kategorija, ali nema dokaza da je maksimalno trajanje života u prošlosti ili kod savremenih preindustrijskih populacija, bilo značajno manje nego što je kod industrijskih zajednica. Zanimljivo je da se situacija menja u poređenju sa našim najbližim rođacima - šimpanzama, jer ljudi pokzuju odloženo sazrevanje, tj. usporeno starenje u odnosu na ostale primate, ${ }^{20}$ što je označeno i kao postmenopauzalna dugovečnost. $\mathrm{Na}$ tragu objašnjenja fenomena dugog postreproduktivnog perioda kod ljudi je tzv. hipoteza babe, ${ }^{21}$ gde je osnovna ideja da žene nastavljaju da žive nakon menopauze, kako bi pomogle svojim ćerkama u odgajanju dece, dakle da budu bake svojim unucima i tako povećaju verovatnoću njihovog preživljavanja. Slično, selekcija je mogla favorizovati dug životni vek roditelja, kako bi dete savladalo čitav niz veština, koje mu omogućavaju materijalno i socijalno preživljavanje, samim tim i reprodukciju. Zanimljivo je da se devojčice rađaju sa brojem primarnih jajnih ćelija, koje su dovoljne za proces ovogeneze sve do 70 20

Odgovor na pitanje o razlici u dugovečnosti kod primata može se sagledati iz perspektive teorije životne istorije, koja predstavlja profil vrste određen prosečnim vrednostima dinamike rasta, polnog sazrevanja, početka i kraja reproduktivnog perioda, dinamike starenja i vremena smrti. Sa stanovišta evolucije, selekcija deluje da favorizuje one jedinke koje imaju maksimalni reproduktivni potencijal, pa se onda njihova učestalost u populaciji povećava. Po zakonima o balansu energije, nema razloga ulagati u oblikovanje takve životne istorije, gde će jedinka da nastavi da živi pošto je prestala da bude reproduktivno sposobna. Ali, kod ljudi je očigledno da žene nadživljuju svoj reproduktivni period i da je prirodna selekcija favorizovala ovaj model (Kristen Hawkes, J. F. O'Connell, N. G. Blurton Jones, H. Alvarez and Eric L. Charnov. "Grandmothering, Menopause, and the Evolution of Human Life Histories." Proceedings of the National Academy of Sciences 95 (February 1998): I336-39, doi:10.1073/pnas.95.3.1336.; Darren P. Croft, Lauren J. N. Brent, Daniel W. Franks and Michael A. Cant, "The evolution of prolonged life after reproduction," Trends in Ecology \& Evolution 30 (July, 2015): 407-16, doi: 10.1016/j.tree.2015.04.011.).

2 I Hawkes et al., "Grandmothering, Menopause, and the Evolution of Human Life Histories," 1336; Daryl P. Shanley and Thomas B. L. Kirkwood, "Evolution of the human menopause," BioEssays 23 (March 2001): 282, doi: I0.1002/1521-1878(200103) 23:3<282::AID-BIES $1038>3.0 . C O ; 2-9$; Jocelyn. S. Peccei, "Critique of grandmother hypothesis:old and new," American Journal of Human Biology 13 (May 2001): 434, doi: I0.1002/ajhb.1076.; Kristen Hawkes, "Grandmothers and the evolution of human longevity," American Journal of Human Biology is (2003): 386, doi:10.1002/ajhb.10156. 
godine života, ali većina njih izumre do oko so. godine (početak menopauze). ${ }^{22}$

Osim poređenja sa primatima, evolutivna istorija ljudske dugovečnosti se može sagledati kroz podatke o životnoj istoriji, koji su dobijeni iz fosilnih hominida. Recimo, primenom Majlsove metode, preko relativne istrošenosti zuba za koje je poznat redosled izbijanja, Kaspari i Li su posmatrale australopitekuse, rane Homo vrste, neandertalce i anatomski savremene ljude (Homo sapiens sapiens) iz ranog gornjeg paleolita. Za potonje je dobijen razultat da najduže žive, kad su se za sve grupe uporedili odnosi broja starih prema broju mladih individua. Medutim, u narednoj studiji su iste autorke napravile razliku između anatomski savremenih ljudi iz zapadne Azije (prvi talas kolonizacije sapijensa van Afrike, pre oko 70000 godina), neandertalaca iz zapadne Azije, evropskih neandertalaca i evropskog sapijensa iz gornjeg paleolita. Najveći procent starih individua, u odnosu na sve ostale ima evropski sapijens, dok se sapijens iz zapadne Azije gotovo ne razlikuje od neandertalca iz zapadne Azije, što je argument koji ne govori u prilog o različitim biološkim kapacitetima za dugovečnost. Znači, radi se o određenim sredinskim i kulturnim razlikama, odnosno o tome da je sapijens u gornjem paleolitu razvio kulturnu adaptaciju, koja je omogućavala veće preživljavanje u odnosu na, kako neandertalce tako i na anatomski savremene ljude iz drugog geografskog i vremenskog konteksta. ${ }^{23}$ Stoga bi se moglo razmišljati o posledicama (prednostima) porasta broja starih ljudi, kroz manifestovane burne tehnološke i umetničke promene $\mathrm{u}$ arheološkom zapisu tokom gornjeg paleolita. Što se tiče procenta starijih od 40 godina u skupu fosilnih ostataka

22 Peccei, "Critique of grandmother hypothesis: old and new," 446. Više o fiziologiji ženskog reproduktivnog sistema videti u: John E. Hall, "Female Physiology Before Pregnancy and Female Hormones," in Guyton and Hall Textbook of Medical Physiology, 13 th edition (Philadelphia: Elsevier Saunders, 2016), 1037-54.

23 Rachel Caspari and Sang-Hee Lee, "Older age becomes common late in human evolution," Proceedings of the National Academy of $\mathrm{Sci}_{\text {- }}$ ences IOI (July, 2004): 10895-900. doi: 10.1073/pnas.0402857101.; Rachel Caspari and Sang-Hee Lee, "Is human longevity a consequence of cultural change or modern biology?" American Journal of Physical Anthropology 129, (April, 2006): 512-7. doi:10.1002/ ajpa. 20360 . individua preko 20 godina starosti, Trinkhaus je - posmatrajući neandertalce, anatomski savremene ljude, koji odgovaraju vremenu evropskog srednjeg paleolita (sapijens iz Afrike) i anatomski savremene ljude iz ranog i srednjeg gornjeg paleolita (evropski sapijens) - otkrio da se neandertalski profili ne razlikuju od profila afričkog i evropskog sapijensa. Čak je najmanje starijih individua kod afričkog sapijensa, što opet govori u prilog činjenici da su kulturološki faktori, a ne biološke razlike, igrali ulogu u dugovočenosti ljudi. ${ }^{24}$

Ne sme se previđati, da očekivani životni vek nije isto što i biološka dugovečnost, pošto zavisi od sredinskih uslova i režima mortaliteta, a ne samo od toga koliko biološki možemo dugo da živimo. Boke-Apel i Dežoan se radili studiju vezanu za neandertalace, gde su korelirane biometrijske karakteristike, poput težine mozga i težine tela, sa dugovečnošću. Dobijene su iste vrednosti kao i za moderne ljude, odnosno da je za obe podvrste isti biološki potencijal dužine života. ${ }^{25}$ Sa druge strane, arheološka istraživanja su se pokazala kao kontradiktorna, pošto su, pre svega, u sam metod određivanja starosti putem klasične skeletne paleodemografske analize, ugrađene pristrasnosti, koje uzrokuju brisanje najstarijih individua iz arheološkog zapisa i samim tim smanjenje dužine života u praistoriji.

\section{Klasična skeletna paleodemografska analiza (KSPDA) i njena ograničenja}

Klasična skeletna paleodemografija je razvijena i formulisana početkom sedamdesetih godina 20. veka, sa metodološkom kodifikacijom u publikaciji Ačada i Nemeškerija - History of Human Lifespan and Mortality. Autori su izložili višegodišnja istraživanja, koja obuhvataju iskope u istoj regiji od mezolita do srednjeg veka. Paleodemografsku analizu su temeljili na izradi tzv.

24 Erik Trinkaus, "Late Pleistocene adult mortality patterns and modern human establishment." Proceedings of the National Academy of Sciences I08 (January, 201 I): 1267-71. doi:10.1073/pnas. I018700108.

25 Jean-Pierre Bocquet-Appel and Anna Degioanni, "Neanderthal demographic estimates," Current Anthropology 54 (December, 2013): $\mathrm{S}_{202}-\mathrm{S}_{213}$, https://www.journals.uchicago.edu/doi/pdfplus/10.1086/673725 (pristupljeno 27.4.2017.). 
tablica mortaliteta ili životnih tabela (life tables), pod pretpostavkom o stacionarnosti populacije, a na osnovu fizičko-antropološke ocene starosti i pola pojedinačnih skeleta. ${ }^{26}$ Radilo se o jednom zaokruženom paketu demografskih tehnika, ali je vremenom uočeno da mnogi alati tog paketa zahtevaju reviziju, tako da se 1982 . pojavio uticajan članak naslovljen Zbogom paleodemografiji. No, krenimo redom.

Demografska rekonstrukcija u KSPDA se dosta razlikuje od demografske analize živih populacija - prvenstveno, zbog niza transformacija, koje nas dele od populacije živih do populacije umrlih, odnosno od sistemskog do arheološkog konteksta. Kao pretpostavka u izradi tablica mortaliteta u KSPDA, važi i da je populacija u normalnom (atricionom) režimu mortaliteta, što se često može iščitati na osnovu starosne strukture skeletne populacije. Za konkretan skeletni materijal se predviđa, da je nepristrasan uzorak ukupne skeletne populacije. To znači, da su se svi članovi zajednice sahranjivali na istom mestu, iako je arheološki i etnografski potvrđeno, na primer, da se sahrane novorođenčadi i dece mogu tretirati drugačije od sahrana odraslih. Sem ovog kulturnog faktora, na nedostatak dečijih skeleta utiču i tafonomski faktori, pa se može očekivati još veća smrtnost dece, nego što je to do sada paleodemografski dokumentovano. Od tafonomskih faktora je najznačajnija kiselost zemljišta, koja utiče na povećanu razgradnju i nestanak kostiju, čemu su naročito podložne kosti najmlađih, ali i najstarijih individua. ${ }^{28}$

Temelj za KSPDA je poznavanje polne i starosne strukture skeletne serije. Odredba pola se vrši makroskopskim posmatranjem niza skeletnih atributa, koji ispoljavaju izraziti polni dimorfizam. Slično važi i za starost, ali uz bar dve otežavajuće okolnosti: nepoklapanja hronološke i biološke starosti, te veće preciznosti u određivanju starosti kod dece. Nije sporno, da postoji niz

\footnotetext{
26 Acsádi and Nemeskéri, History of Human Life Span and Mortality, 263-309;; Mallegni, "Paleoantropologija," soo.

27 Jean-Pierre Bocquet-Appel and Claude Masset, "Farewell to paleodemography," Journal of Human Evolution I I, no. 4 (1982): 32 I.

28 Порчић, Палеодемографија: критички преглед теорије, метода и истраживатьа, 120, 124-5.
}

skeletnih atributa, čija se morfologija ili veličina menjaju tokom vremena, odnosno kroz procese starenja. Sporno je što se, u zavisnosti od načina života, procesi starenja odvijaju različitom brzinom. Zato se može desiti da dve osobe koje imaju isti broj godina - biološki ne izgledaju kao da su iste starosti. Drugim rečima, hronološka starost (broj godina od rođenja do smrti individue) i biološka starost (određena putem klasične makroskopske antropološke analize) nisu sinonimi. ${ }^{29}$

Naredni problem se tiče preciznosti u determinaciji starosti, pre svega nemogućnosti procene starosti skeleta onih individua, koje imaju više od so godina. Naime, prvo što uočite kada vršsite makroskopsku procenu starosti u KSPDA, je da vam značajno manjkaju individue, čiju bi starost opredeli u 50 godina ili više. Stoga, umesto navođenja intervala, recimo, od 50 do 55 godina, jednostavno je postojala oznaka starosti $45+(45$ ili više godina). Na taj način je automatski izbrisana, uslovno govoreći, metuzalemska starost i eventualne različite kulturne prakse, koje bi se pročitale iz konteksta sahrane najstarijeg dela populacije. ${ }^{30}$ Zašto je to tako? Odgovor je u različitoj pouzdanosti ocene starosti kod odraslih i kod dece. Naime, makroskopski atributi skeleta, koji menjaju morfologiju i/ili veličinu $s$ vremenom, uzimaju određene vrednosti, koje nazivamo skeletnim indikatorima starosti. Ako postoji zakonomernost, na osnovu tog atributa se može određivati starost sa većom ili manjom preciznošću. Problem je što se preciznost smanjuje sa starošću, što znači da se najtačnije određuje starost kod dece. Na primer, nicanje zuba ili srastanje epifiza dugih kostiju su procesi rasta sa visokom hronološkom rezolucijom, u odnosu na degenerativne procese, kao što su trošenje zuba, aurikularnih površina i pubičnih simfiza. Prvi su pod direktnom genetskom kontrolom, dok su drugi podložniji sredinskim faktorima i zavise od na-

29 Ariane Kemkes-Grottenthaler, "Aging through the Ages: Historical Perspectives on Age Indicator Methods," in Paleodemography: Age Distributions from Skeletal Samples, eds. Robert D. Hoppa and James W. Vaupel, (Cambridge: Cambridge University Press, 2002), $48-50$.

30 Cave and Oxenham, "Identification of the archaeological invisible elderly: An approach illustrated with an Anglo-Saxon example," 163. 
čina života. To je vidljivo čak i u klasičnoj antropološkoj podeli starosnih grupa, gde za osobe do 20 godina starosti imamo čak tri starosne kategorije, koliko ih je i za trostruko duži period od 20 do 80 godina: Infans I (o-6), Infans II (714), Juvenilis (15-20), Adultus (2 I-40), Maturus (4I-60) i Senilis (6I-80). Zato je analiza taloženja zubnog cementa, za sad najprecizniji metod određivanja individualne starosti. Zubni cement se godišnje širi za jedan prsten, što je u velikoj meri pod genetskom kontrolom. Svakako je pozitivno što je metod, pre svega, zasnovan na fiziologiji stvaranja zubnog cementa, a ne na poređenju sa referentnom zbirkom. ${ }^{31}$

Referentne osteološke zbirke su formirane za potrebe KSPDA i čine ih skupovi skeleta onih individua, za koje imamo istorijske i medicinske podatke o vremenu smrti. ${ }^{32}$ Sa njima poredimo (arheološke) skeletne zbirke, kako bi odredili vreme smrti u arheološkom kontekstu. Sa porastom broja objavljenih rezultata, postajalo je očigledno nepoklapanje u starosnoj strukturi skeletnih zbirki - kako sa istorijski i etnografski zabeleženim starosnim profilima umrlih populacija, tako i sa modelskim tablicama mortaliteta, generisanih na osnovu podataka o preindustrijskim zajednicama. Štaviše, sve arheološke serije pokazuju sledeće zajedničke karakteristike: manjak individua u najmlađoj starosnoj kategoriji (prvenstveno, od o do I godina); višak individua između 25 i 45 godina, što se na grafikonima manifestuje kao tzv. grba odraslih; i naposletku, manjak individua starijih od 50 i 60 godina. Ove tri karakteristike se lepo vide na primeru Liben nekropole (Slika 2), koja broji 1327 skeleta (Severna Amerika, Ohajo, kraj I. milenijuma naše ere), ali i na primeru eneolitske Budakalaš nekropo$\mathrm{le}^{33}$ sa teritorije današnje Mađarske (Slika 3); od-

31 Bocquet-Appel and Masset, "Farewell to paleodemography," 321 -6.; Порчић, Палеодемографија: критички преглед теорије, метода и истраживата, $123-4$.

32 Bethany M. Usher, "Reference Samples: the First Step in Linking Biology and Age in the Human Skeleton," in Paleodemography: Age Distributions from Skeletal Samples, eds. Robert D. Hoppa and James W. Vaupel (Cambridge: Cambridge University Press, 2002), 29-47.

33 U okviru osnovnih studija arheologije na Filozofskom fakultetu u Beogradu, pri predmetu Paleodemografija, raden je istraživački rad koji se ticao izrade tablice mortaliteta za badensku nekropolu Budakálsz-Luppa csárda na osnovu KSPDA, a prema primarnim

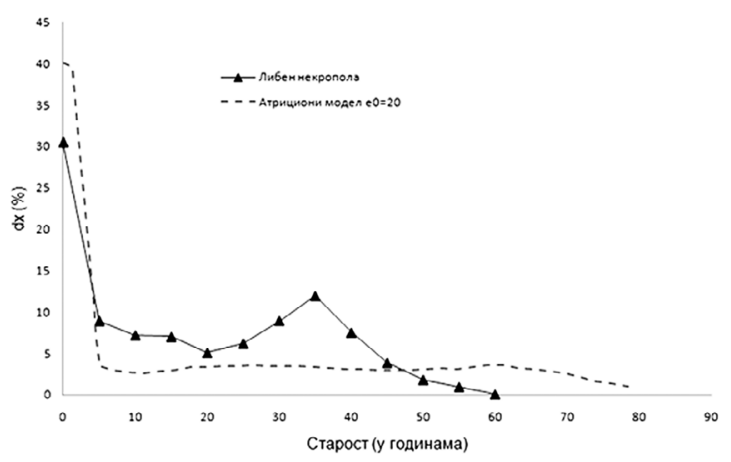

Slika 2. Starosna struktura Liben (Libben) nekropole (parametar $d x$ iz tablice mortaliteta je proporcija umrlih tokom intervala $x$ ). Kao referentna je isprekidanom linijom data starosna struktura prema modelskoj tablici mortaliteta za preindustrijske zajednice sa očekivanim životnim vekom pri rođenju od 20 godina (Izvor: Порчић, Палеодемографија: критички преглед теорије, метода и истраживатьа, слика 49, 138.).

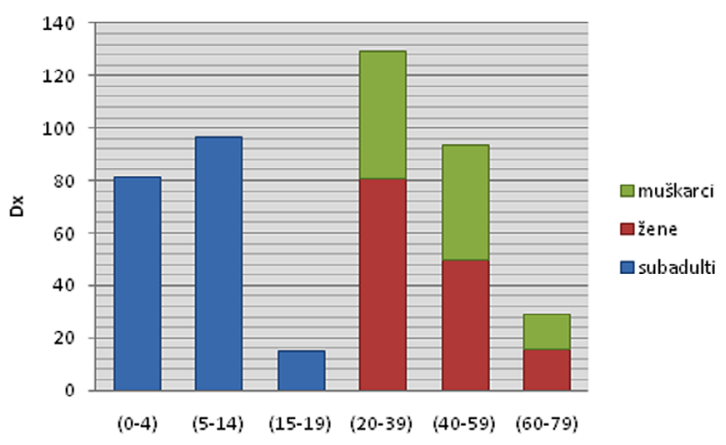

Slika 3. Starosna struktura populacije umrlih za eneolitsku nekropolu Budakalász (Dx je broj umrlih po starosnoj kategoriji). Primetna je „grba odraslih” karakteristična za grafikone starosne strukture skeletnih zbirki, koja se odnosi na višak individua između $20 \mathrm{i} 4 \mathrm{O}$ godina starosti, a postoji manjak individua uzrasta o do 5 godina i individua preko 60 godina. Najveća smrtnost žena je na vrhuncu reproduktivnog perioda (Izvor: osobni istraživački rad Zorana Dimković.).

podacima o starosti i polu, preuzetim iz kataloga grobova u monografiji o ovom nalazištu (Mária Bondár, "The cemetery (with catologue of graves)," in The copper age cemetery of Budakalász, eds. M. Bondár and P. Raczky (Budapest: Pytheas, 2009), II-196.). Skeletna serija, koju čine 445 individue, je dala tipičan klasičan paleodemografski profil sa izraženim pristrasnostima, koje su ugrađene u sam metod, a tiču se manjka individua iz najstarije starosne kategorije, odnosno viška individua u adultus kategoriji (grba odraslih). 
nosno, vidljive su na starosnim profilima svih skeletnih zbirki, dobijenim putem KSPDA, koje dolaze iz različitih vremena, prostora i kultura. Da li to treba da znači, da je mortalitet praistorijskih zajednica bio drastično drugačiji u odnosu na mortalitet preindustrijskih zajednica, koje možemo etnografski da posmatramo ili je, pak, u pitanju nešto vezano za sam metod? Istraživači Liben nekropole su tvrdili, da je u pitanju ovo prvo: demografsko iskustvo autentičnih praistorijskih ljudi je drugačije u odnosu na preindustrijske zajednice, koje su etnografski zabeležene. Smatrali su da je, zbog kontakta sa Evropljanima, došlo do smanjenja mortaliteta usled dostupnije bolje nege, ali i do povećanja mortaliteta usled različitih bolesti (naročito mortaliteta dece), pa je zapravo ono što vidimo arheološki - jedno autentično demografsko iskustvo ljudi pre kontakta sa Evropljanima. Ipak, posumnjalo se u ovo objašnjenje, te je baš na osnovu starosne strukture umrlih sa Liben nekropole, proračunato kako bi izgledala struktura živih ljudi. Pokazalo se, da bi u hipotetičkoj populaciji živih dominirale veoma mlade osobe i deca koja nemaju ni roditelje, a ni dede i babe, zbog visokog mortaliteta, što znači da bi takva populacija bila pod ogromnim stresom, jer ne bi bilo dovoljno ljudi koji bi mogli da proizvode hranu. Ovi rezultati su naveli paleodemografe na razmišljanje, da postoji nešto u metodu KSPDA, što proizvodi gore pomenuti obrazac (manje umiranje beba, zatim tzv. grba odraslih i manjak najstarijeg dela populacije). Kada je reč o učestalosti najmlađih, tu su se ponudila rešenja, koja se tiču tafonomije i različitih kulturnih praksi. Ali, i dalje je ostajalo nerešeno pitanje objašnjenja viška umrlih u

\footnotetext{
Starosna i polna struktura svedoče o atricionom mortalitetu i pokazateljima fertiliteta, koji su u skladu sa dosadašnjim istraživanjima za eneolitski period. Upućuje na sistemsku (živu) populaciju koja je mogla da broji prosečno samo oko 55 individua, s obzirom na trajanje nekropole od 240 godina i na očekivani životni vek na rođenju od oko 27 godina, što se takođe uklapa u prosečne vrednosti za eneolit. Sa druge strane, evidentan je manjak individua iz najmlađe starosne kategorije, za koje je opravdano očekivati veći broj, pogotovu kad se ima u vidu procenjena visoka stopa rasta od $1.75 \%$. Polna struktura odraslih svedoči o većoj smrtnosti žena u odnosu na muškarce, s tim da je najupadljivija razlika medu polovima je u starosnoj kategoriji adultus sa gotovo dvostrukim udelom žena u odnosu na muškarce, iz čega sledi da je najveća smrtnost žena bila upravo na vrhuncu reproduktivnog perioda.
}

periodu od 25 do 45 godina i manjak umrlih u dubljoj starosti. ${ }^{34}$

Kao što je rečeno, godine 1982 . pojavio se članak Zbogom paleodemografiji, gde su autori Boke-Apel i Mase, izneli tri osnovna zaključka o KSPDA: r. da su ocene starosti arheoloških populacija u proseku uvek pristrasne ka prosečnoj starosti referentne populacije, što znači, da će od toga kolika nam je prosečna starost u referentnoj zbirci, zavisiti ocena starosti u arheološkoj situaciji; 2. da korelacije između indikatora starosti i same ostvarene starosti nisu dovoljno visoke, što daje veliku marginu greške (na primer, ako je reč o jednom prilično nepreciznom indikatoru, kao što je srastanje lobanjskih šavova, veliki je raspon godina u kojima dolazi do srastanja određenog šava, tako da imamo nepreciznost od oko bar petnaestak godina u oceni starosti odraslih osoba) i 3. usled svega ovoga, KSPDA imitira starosnu strukturu referentne serije i ne donosi nikakvo novo znanje o demografiji ljudi u prošlosti. Boke-Apel i Mase su ovo ilustrovali pomoću linearne regresije. Prikazali su, da je prosečna ocenjena starost arheološke serije prosta mimikrija prosečne starosti referentne serije. Znači, kako se bude menjao oblik starosne strukture referentne serije, menjaće se i ocena starosti u arheološkoj seriji, što je loša situacija, budući da postoji samo jedna ispravna starosna struktura i jedna prosečna starost arheološke serije. Ovo je ozbiljan minus KSPDA, poznat kao skeletna mimikrija. Srž problema je u nepouzdanoj primarnoj oceni starosti individue na osnovu indikatora, jer starost uzrokuje vrednost indikatora, a ne obratno. U arheološkom kontekstu, poznat nam je indikator, te kad želimo da predviđamo starost na osnovu indiktora, tu više nema stabilnosti, pošto vrednost indikatora ni na koji način ne uzrokuje starost. ${ }^{35}$

\footnotetext{
34 Richard S. Meindl, Robert P. Mensforth and C. Owen Lovejoy, "The Libben Site: a Hunting, Fishing, and Gathering Village from the Eastern Late Woodlands of North America. Analysis and Implications for Palaeodemography and Human Origins," in Recent Advances in Palaeodemography, ed. Jean-Pierre Bocquet-Appel (Dordrecht: Springer, 2008), 259-75.; Порчић, Палеодемографија: критички преглед теорије, метода и истраживана, $137-9$.

35 Bocquet-Appel and Masset, "Farewell to paleodemography," 322-4.
} 
Starosna mimikrija arheološkog skeletnog materijala predstavlja objašnjenje za tipični obrazac mortaliteta dobijen putem KSPDA: relativni višak individua u odraslim starosnim kategorijama i manjak najstarijih individua. U praksi, recimo, za ocenjivanje starosti na osnovu morfologije pubične simfize, kao referentna zbirka je služila zbirka skeleta američkih vojnika poginulih u korejskom ratu sredinom 20. veka, tako da je prosečna starost za sve indikatore bila pristrasna ka mlađim starosnim kategorijama, s obzirom na to da vojničku populaciju čine uglavnom mlađi odrasli muškarci. ${ }^{3}$

\section{Zaključak}

Kada je reč o paleodemografiji, prvo što treba imati na umu je da arheološka skeletna populacija nije preslikana sinhrona živa populacija, niti joj odgovara po veličini i strukturi, već se događa niz sukscesivnih transformacija od sistemskog do arheološkog konteksta. Jedna od metoda rekonstrukcije demografskih parametara žive populacije (u prošlosti) je klasična skeletna paleodemografska analiza (KSPDA).

Za ovu analizu je polazna tačka određivanje pola i starosti za svaku individuu iz arheološke skeletne serije, koje se potom grupišu u starosne intervale od po pet godina i u kategorije infans, juvenilis, adultus, maturus, senilis. Primarni podaci o oceni individualne starosti i pola se tako pretvaraju u formu pogodnu za konstrukciju tablice mortaliteta (life tables), na osnovu koje možemo izračunati očekivani životni vek pri rođenju, koji se pogrešno interpretirao i kao dužina maksimalnog trajanja života. Takođe, preko istih tablica, se dolazi do procene trajanja života i za sve ostale starosne intervale, računa se verovatnoća smrti, te veličina živih populacija u prošlosti i dobija se krivulja preživljavanja. Grafički prikaz izračunatih paleodemografskih parametara (starosni profil populacije), dalje se poredi sa drugim populacijama, pošto možemo pretpostaviti da generalno na sve skeletne populacije deluju isti faktori pristrasnosti. Uz to se može odre-

36 Порчић, Палеодемографија: критички преглед теорије, метода и истраживата, 139-41. diti, da li je starosni profil posledica normalnog režima mortaliteta, a ne nekog vanrednog katastrofičnog događaja, što bi dalo drastično drugačije stope mortaliteta i koliko-toliko preslikavanje starosne strukture živih u strukturu umrlih. Pri normalnom (atricionom) režimu mortaliteta, međutim, pojavljuje se tipično kod arheoloških zbirki, jedan obrazac starosne strukture sa većom učestalošću mlađih odraslih osoba i nedostatkom starijih osoba. Problem je suštinski vezan za razvijanje metoda ocenjivanja starosti na osnovu referentne zbirke, a manifestuje se kao manjak individua u najmlađoj starosnoj kategoriji (pre svega, od o do I godina), lažno povećanje učestalosti individua između 20 i 40 ili između 25 i 45 godina (što se na grafikonima manifestuje kao tzv. grba odraslih) i, manjak individua starijih od 50 i 60 godina. Razlog tome je starosna mimikrija skeletne zbirke: njena prosečna starost teži ka prosečnoj starosti referentne zbirke. Dodatno, zbog nepreciznosti indikatora individualne starosti, KSPDA produkuje netačne starosne profile skeletnih populacija. Problem se odnosi pre svega na procenu starosti odraslih osoba, jer je veći raspon za određene vrednosti indikatora kod odraslih, posebno onih u dubljoj starosti, a samim tim i nepreciznost, nego kod dece i adolescenata. ${ }^{37}$

Nasuprot negaciji dugovečnosti u arheološkom zapisu, uzeti zajedno, istorijski i etnografski podaci, kategorično pobijaju hipotezu da je starenje u prošlosti rapidnije nastupalo nego danas. Ako se tome pridodaju dokazi iz evolucione biologije i antropologije - o potmenopauzalnoj dugovečnosti ljudi i kuturnoj instituciji baka i deka - već od gornjeg paleolita možemo da pretpostavimo porast učestalosti indvidua, sa maksimalnim životnim vekom bar duplo većim od 35 godina. Naravno da je zbog razvoja medicine došlo do produženja prosečnog životnog veka, ali razlike u dugovečnosti - kao biološkom kapacitetu naše vrste, a potom i kao verovatnoj kulturnoj adaptaciji u evropskom gornjem paleolitu - nisu toliko dramatične, kad je reč o prosečnoj dužini

37 Ibid, I4I. 
maksimalnog trajanja života u preindustrijskim i industrijskim zajednicama.

Naposletku, sumirajući razloge za neslaganje klasičnih skeletnih podataka sa pisanim, etnološkim i biološkim izvorima o ljudskoj dugovečnosti, mogu se izdvojiti sledeće najvažnije pristrasnosti ka većoj učestalosti mlađih odraslih individua u skeletnim zbirkama i posledičnog brisanja doživljavanja duboke starosti u prošlosti: a) izjednačavanje očekivanog životnog veka pri rođenju (koji je u preindustrijskim populacijama izrazito smanjen zbog velike smrtnosti beba) i prosečnog maksimalnog trajanja života, b) izjednačavanje hronološke i biološke starosti, c) nepreciznost makroskopskih skeletnih indikatora za individue preko so godina starosti, i d) skeletna mimikrija u KSPDA.

\section{Povzetek}

Paleodemografske raziskave so zelo pomembne pri arheoloških in antropoloških teorijah. Gre za demografsko proučevanje ljudi iz preteklosti, ki temelji na arheoloških ostankov. Klasična skeletna paleodemografija se ukvarja z raziskavami okostij z arheoloških najdišč. Po klasični metodi, ki se izvaja s pomočjo makroskopske analize, skeletni ostanki kažejo, da je bila pogosto velika smrtnost odraslih individua od 20 do 40 let in da v preteklosti ni bilo ljudi starejših od 50 in 60 let. Ko je ugotovljeno, da se ta vzorec ponavlja $v$ vseh predindustrijskih populacijah, ne glede na prostor in čas, se je v osemdesetih letih 20. stoletja izrazil resno kritiko klasične skeletne paleodemografske analize. Po drugi strani, biološki, zgodovinski in etnološki podatki podpirajo obstoj dolgoživosti v predindustrijskih skupnostih. Poleg skeletne mimikrije, negaciji dolgoživosti v arheološkem kontekstu so prispevali: izenačenje pričakovane življenjske dobi ob rojstvu (ki je v predindustrijskih populacijah veliko manjša, zaradi visoke umrljivosti dojenčkov) in povprečnega maksimalnega trajanja življenja, nato pa izenačevanje kronološke in biološke starosti ter netočnost makroskopskih skeletnih kazalnikov starosti za posameznike, ki so starejši od so let.

\section{Summary}

Paleodemographic research is of great importance in archeological and anthropological theories. This is a de- mographic study of people from the past based on archaeological remains. In the context of skeletal paleodemography, these remains are skeletal remains of people, whose macroscopic analysis of the age at the moment of death, determined the increased mortality of adults between 20 in 40 years and the shortage of people older than 50 and 60 years. Because this pattern was repeated (in both hunting-gathering and farming communities, that is, in all preindustrial populations, regardless of space and time) in the 1980 s was made a serious critique of classic skeletal paleodemographic analysis. On the other hand, biological, historical and ethnological data support the existence of longevity in preindustrial communities. In addition to skeletal mimicry, the negation of longevity in the archaeological context contributed to: equalizing life expectancy at birth (extremely low in preindustrial populations due to the high mortality of the children) and the average maximum life expectancy, then equalizing calendar and biological age, and the inaccuracy of macroscopic skeletal age indicators for in dividuals over 50 years.

\section{Literatura}

Acsádi, György, and János Nemeskéri. History of Human Life Span and Mortality. Budapest: Akadémiai Kiado, 1970.

Bocquet-Appel, Jean-Pierre, and Claude Masset. "Farewell to paleodemography." Journal of Human Evolution II, no. 4 (1982): $32 \mathrm{I}-33$.

Bocquet-Appel, Jean-Pierre, and Anna Degioanni. "Neanderthal demographic estimates." Current Anthropology 54 (December, 2013): S2O2-13. https:// www.journals.uchicago.edu/doi/ pdfplus/ıo.1086/673725

Bondár, Mária. “The cemetery (with catologue of graves)." In The copper age cemetery of Budakalász, eds. M. Bondár and P. Raczky, II-196. Budapest: Pytheas, 2009. Caspari, Rachel, and Sang-Hee Lee. "Older age becomes common late in human evolution." Proceedings of the National Academy of Sciences IOI (July, 2004): I0895-900. doi: 10.1073/pnas.0402857IOI. 
Caspari, Rachel, and Sang-Hee Lee. "Is human longevity a consequence of cultural change or modern biology?" American Journal of Physical Anthropology I29, (April, 2006): 512-7. doi:10.1002/ajpa.20360.

Cave, Christine, and Marc Oxenham. "Identification of the archaeological 'invisible elderly': An approach illustrated with an Anglo-Saxon example." International Journal of Osteoarchaeology 26, (August 2014): 16375. doi: 10.1002/0a.2408.

Chamberlain, Andrew. Demography in Archaeology. Cambridge: Cambridge University Press, 2006.

Croft, Darren P., Lauren J. N. Brent, Daniel W. Franks and Michael A. Cant. "The evolution of prolonged life after reproduction." Trends in Ecology \& Evolution 30 (July, 2015): 407-16. doi: $10.1016 /$ j.tree.2015.04.01I.

Gurven, Michael, and Hillard Kaplan. "Longevity among Hunter-Gatherers: A Cross-Cultural Examination.” Population and Development Review 33 (Jun 2007): 32I-65. http://www.jstor.org/ stable/25434609.

Hall, John E. "Female Physiology Before Pregnancy and Female Hormones." In Guyton and Hall Textbook of Medical Physiology, i3th edition, 1037-54. Philadelphia: Elsevier Saunders, 2016.

Harlow, Mary, and Ray Laurence. Growing Up and Growing Old in Ancient Rome. London: Routledge, 2002.

Hawkes, Kristen, J. F. O’Connell, N. G. Blurton Jones, H. Alvarez and Eric L. Charnov. "Grandmothering, Menopause, and the Evolution of Human Life Histories." Proceedings of the National Academy of Sciences 95 (February 1998): 1336-39, doi:10.1073/pnas.95.3.1336.

Hawkes, Kristen. "Grandmothers and the evolution of human longevity." American Journal of Human Biology is (April 2003): 380-400, doi:10.1002/ajhb.10156.
Kemkes-Grottenthaler, Ariane. “Aging through the Ages: Historical Perspectives on Age Indicator Methods." In Paleodemography: Age Distributions from Skeletal Samples, eds. Robert D. Hoppa and James W. Vaupel, 48-72. Cambridge: Cambridge University Press, 2002.

Mallegni, Francesco. "Paleoantropologija." U Arbeološki rječnik, ur. Daniele Manacorda i Ricardo Francovich, 495-502. Zagreb: Sandorf, 2014.

Meindl, Richard S., Robert P. Mensforth and C. Owen Lovejoy. "The Libben Site: a Hunting, Fishing, and Gathering Village from the Eastern Late Woodlands of North America. Analysis and Implications for Palaeodemography and Human Origins." In Recent Advances in Palaeodemography, ed. Jean-Pierre Bocquet-Appel, 259-75. Dordrecht: Springer, 2008.

Peccei, Jocelyn S. "Critique of grandmother hypothesis: old and new." American Journal of Human Biology 13 (May 2001): 434-52. doi: 10.1002/ajhb.1076.

Порчић, Марко. Палеодемографија: критички преглед теорије, метода и истраживаға. Београд: Универзитет у Београду, $\Lambda$ абораторија за биоархеологију, 2016.

Shahar, Shulamith. Growing Old in the Middle Ages: 'Winter Clothes Us in Shadow and Pain'. London: Taylor \& Francis, 2002.

Shanley, Daryl P., and Thomas B. L. Kirkwood. "Evolution of the human menopause." BioEssays 23 (March 200I), 282-87. doi: I0.1002/152I-I878(200103)23:3<282::AIDBIESIO38>3.0.CO;2-9.

Šašel Kos, Marjeta. "Nutrices: the most popular goddesses at Poetovio.” In Zentralort und Tempelberg. Siedlungsund Kultentwicklung am Frauenberg bei Leibnitz im Vergleich, Akten des Kolloquiums im Schloss Seggau am 4. und s. Mai 2015, hrsg. Manfred Lehner 
und Bernhard Schrettle, 167-74. Wien:

Phoibos Verlag, 2016.

Trinkaus, Erik. "Late Pleistocene adult mortality patterns and modern human establishment." Proceedings of the National Academy of Sciences 108 (January, 2011): I267-71. doi:10.1073/pnas.I018700108.

Usher, Bethany M. "Reference Samples: the First Step in Linking Biology and Age in the Human Skeleton." In Paleodemography: Age Distributions from Skeletal Samples, eds. Robert D. Hoppa and James W. Vaupel, 29-47. Cambridge: Cambridge University Press, 2002.

Visočnik, Julijana, in Maja Sužnik.

"Vojaški napisi iz Celeje in njene okolice." Arheološki vestnik 59 (2008): 325-57. http://www.dlib. si/?URN=URN:NBN:SI:docWSQU4VXK. 


\title{
Arheološke raziskave na lokaciji Kaštelir nad Kortami v letu 2014
}

\author{
Alenka Tomaž, Fakulteta za humanistične študije, Univerza na Primorskem, Koper \\ Maša Sakara Sučević, Pokrajinski muzej Koper
}

Kaštelir nad Kortami pri Izoli je ena od najbolje poznanih prazgodovinskih naselbin v slovenskem delu Istre. Najdišče je prvi omenjal že Pietro Coppo v i6. stoletju, na začetku 20. stoletja ga je Carlo Marchesetti označil kot Il castelliere d'Albuzzano presso Corte d'Isola, prve sistematične arheološke raziskave pa so potekale v 60 -ih in 70 -ih letih 20. stoletja. Z njimi je bil tudi prvič potrjen izjemen pomen najdišča kot prazgodovinskega kaštelirja. Med leti 2008 and 2014 je arheološka lokacija Kaštelir nad Kortami postal glavni poudarek projekta „Kaštelir nad Kortami - Kulturno-rekreacijski part“, ki ga je finančno podpirala Občina Izola, izvajali pa raziskovalci Univerze na Primorskem. V članku prikazujemo rezultate arheološkega testnega sondiranja, izvedenega v letu 20I4, ki kažejo na to, da je Kaštelir nad Kortami potrebno razumeti ne samo kot prazgodovinsko naselbinsko točko ampak tudi kot prostor zelo zgodnje rimske poselitve.

Ključne besede: Kaštelir nad Kortami, prazgodovinsko gradišče, rimska poselitev, Istra

Kaštelir above Korte near Izola is one of the best known prehistoric settlements in the Slovenian part of Istria. The site was first mentioned by Pietro Coppo in the $16{ }^{\text {th }}$ Century, at the beginning of $20^{\text {th }}$ Century Carlo Marchesetti described the site as Il castelliere d'Albuzzano presso Corte d'Isola, however the first proper archaeological excavation took place in the 60's and $70^{\prime}$ 's of $20^{\text {th }}$ Century. With it the site was confirmed as a prehistoric hillfort of exceptional importance. Between 2008 and 2014 Kaštelir has been a main focus of the project "Kaštelir above Korte - Cultural and recreational park", financially supported by the Municipality of Izola and conducted by research team from University of Primorska. In article we are presenting results of the archaeological test probing, done in 20I4, which demonstrates that Kaštelir above Korte must be considered not only as a prehistoric settlement but also a place of a very early Roman settlement.

Key words: Kaštelir above Korte, prehistoric hillfort, roman settlement, Istra

$\mathrm{K}$ aštelir nad Kortami pri Izoli velja za eno večjih prazgodovinskih naselbin $\mathrm{v}$ slovmorske višine tik nad vasjo Korte na južni vzpetini grebena, ki se vleče od Kort do Malije. Sam vrh Kaštelirja je, geomorfološko gledano, obsežna planota ovalne oblike, vsem poznano arheološko najdišče pa leži na vzdolžni vzpetini s položnimi pobočji na vzhodni in strmim pad- cem na severni strani. Sledi obodne arhitekture prazgodovinskega gradišča/kaštelirja so sicer še dobro vidni, vendar na več mestih povsem preraščeni z neprehodnim rastjem (sl. I).

Med leti 2008-2014 je potekal projekt Kaštelir nad Kortami - Kulturno rekreacijski park, ki ga je ob podpori Občine Izola izvajal Inštitut za dediščino Sredozemlja Znanstveno-ra- 


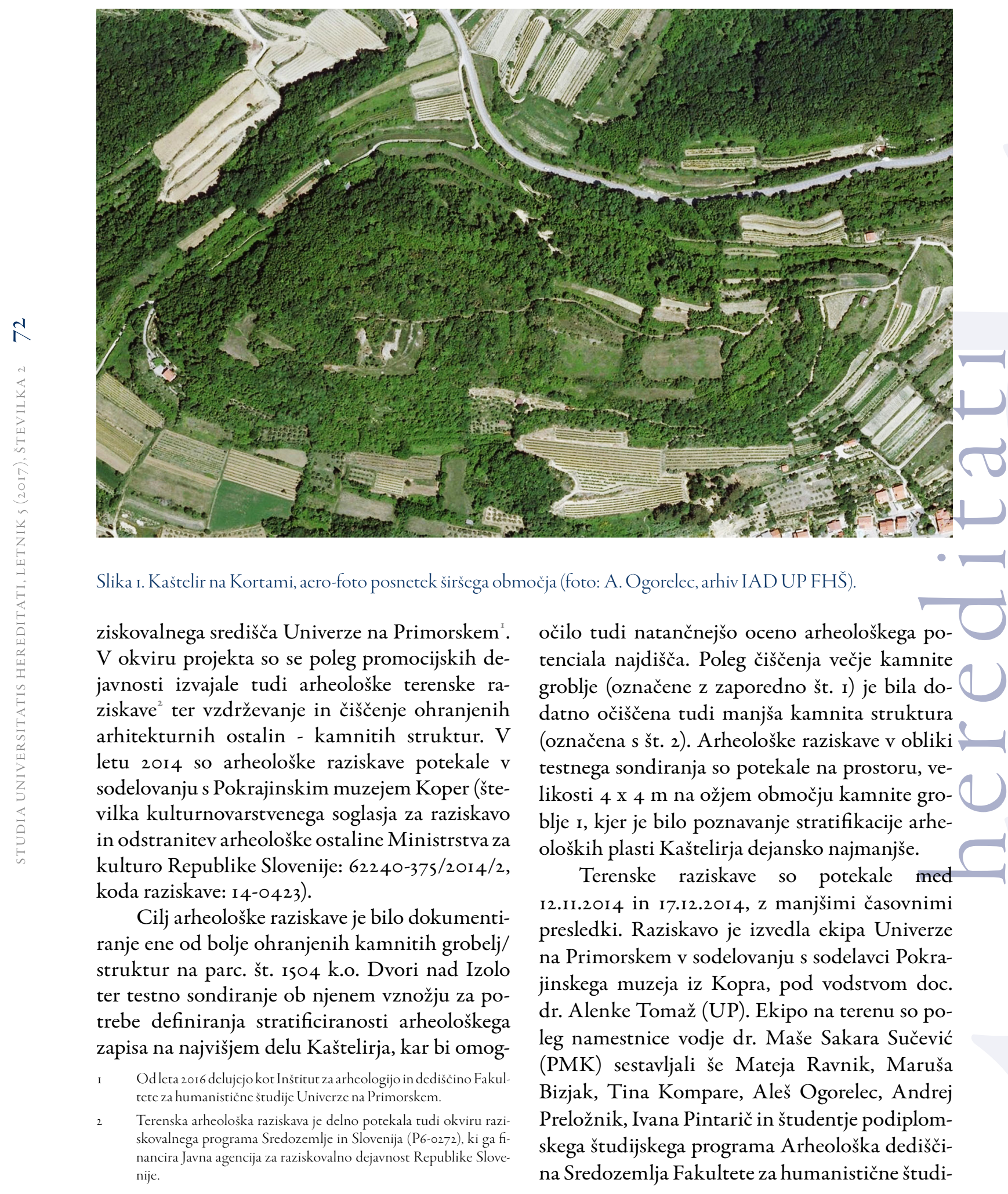




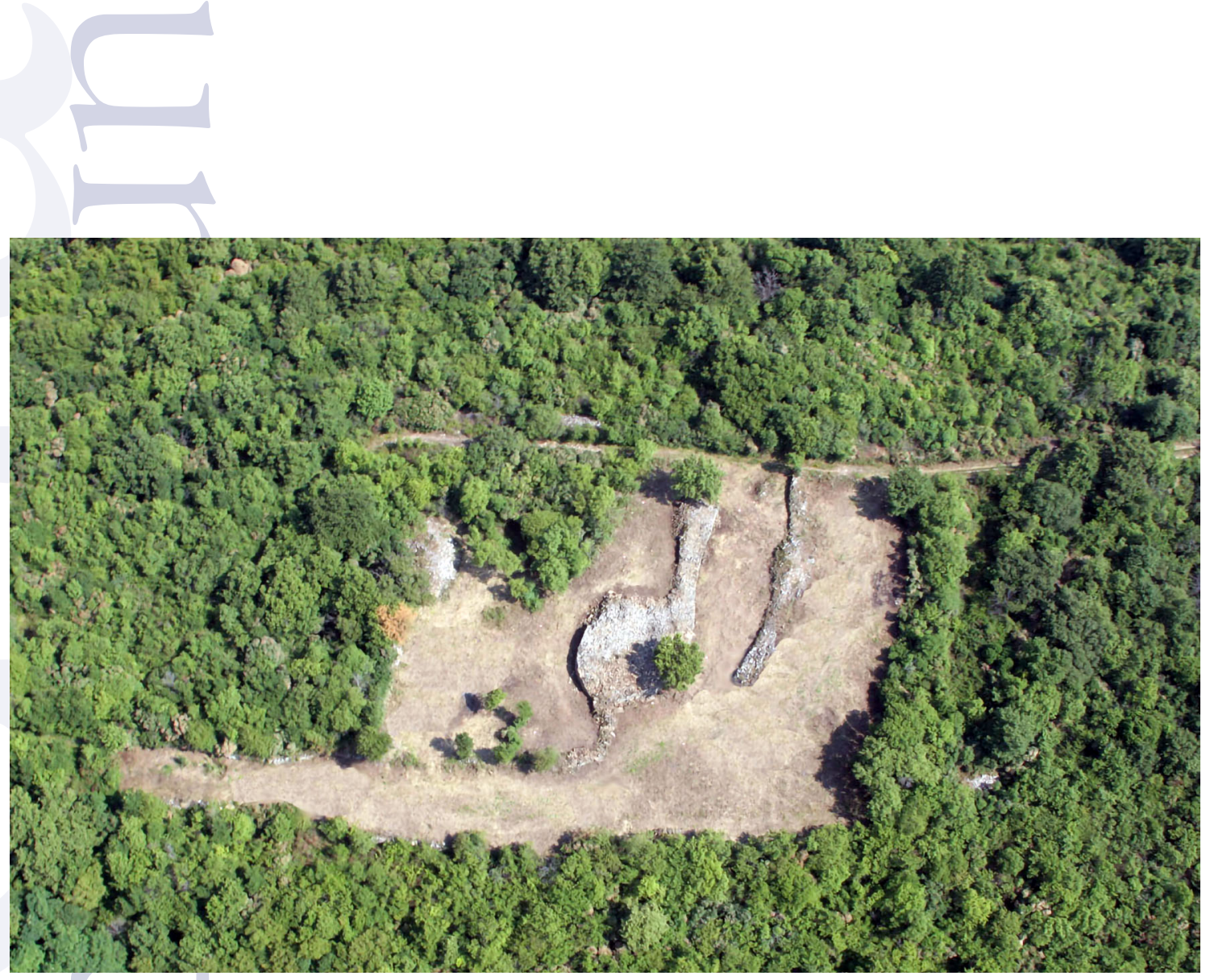

Slika 2. Kaštelir na Kortami, aero-foto posnetek očiščenih kamnitih struktur v letu 2009 (foto: A. Ogorelec, arhiv IAD UP FHŠ).

je Univerze na Primorskem, Valentin Babuder, Aleksander Močibob in Peter Šuler.

\section{Kaštelir nad Kortami - kratka zgodovina arheoloških raziskav}

Zgodovina raziskav Kaštelirja nad Kortami je bila ob več priložnostih že nadrobno predstavljena tudi širši javnosti ${ }^{3}$, zato na tem mestu navajamo le najpomembnejše poudarke iz relativno dolge zgodovine raziskav najdišča.

Najstarejša omemba najdišča sodi v i6. stoletje. Pietro Coppo omenja Kaštelir z imenom Albucan, kot starodavno prebivališče Izolčanov in sicer, da gre za enega najvišjih hribov v notranjosti Istre, na pol poti do Grožnjana. Grki naj bi kraj poimenovali Vrano Casto (oz. Vrano Cas-

\footnotetext{
Maša Sakara Sučević, Prazgodovinska keramika med Miljskim zalivom in porečjem Mirne, (Fakulteta za humanistične študije, Univerza na Primorskem, doktorska disertacija - neobjavljena, 2012); Alenka Tomaž in Maša Sakara Sučević, Kaśtelir nad Kortami - historična analiza prostora (elaborat) (Koper: Inštitut za dediščino Sredozemlja, Znanstveno-raziskovalno središče, Univerza na Primorskem, 2014).
}

tro, tudi Castro - Uranion), Latinci Castelaerio oz. Castel Celeste oz. Castru Arium, v vulgarnem jeziku pa naj bi mu rekli Castelir (Kaštelir) ${ }^{4}$. Hrib Albucan omenja tudi G. Thamar leta I58I. D. Fortunato Olmo pa leta I885 navede vsa antična poimenovanja, ki se razlikujejo od poimenovanj Pietra Coppa le s podatkom o poimenovanju Argonautov, ki naj bi ga imenovali Vranio.

Carlo Marchesetti je Kaštelir opisal kot Il castelliere d'Albuzzano presso Corte d'Isola. Obenem je podal načrt gradišča z obodnim in dvema prečnima nasipoma ter omenil, da je bila pred kakšnim letom (torej okrog leta 1900) tu najdena, danes izgubljena, bronasta sulična ost: bella lancia di bronzo $0^{6}$.

4 Sakara Sučević, Prazgodovinska keramika med Miljskim zalivom in porečjem Mirne.

$5 \quad$ Ime Albuzan se med italijansko govorečim prebivalstvom ohrani vsaj še do druge svetovne vojne, kot kažejo napisi na škatlah v depoju PMK iz leta 1941.

6 Carlo Marchesetti, I castellieripreistorici di Trieste e della regione Giulia (Trieste: Museo civico di Storia naturale, 1903), 74, t. 9: f. I. 

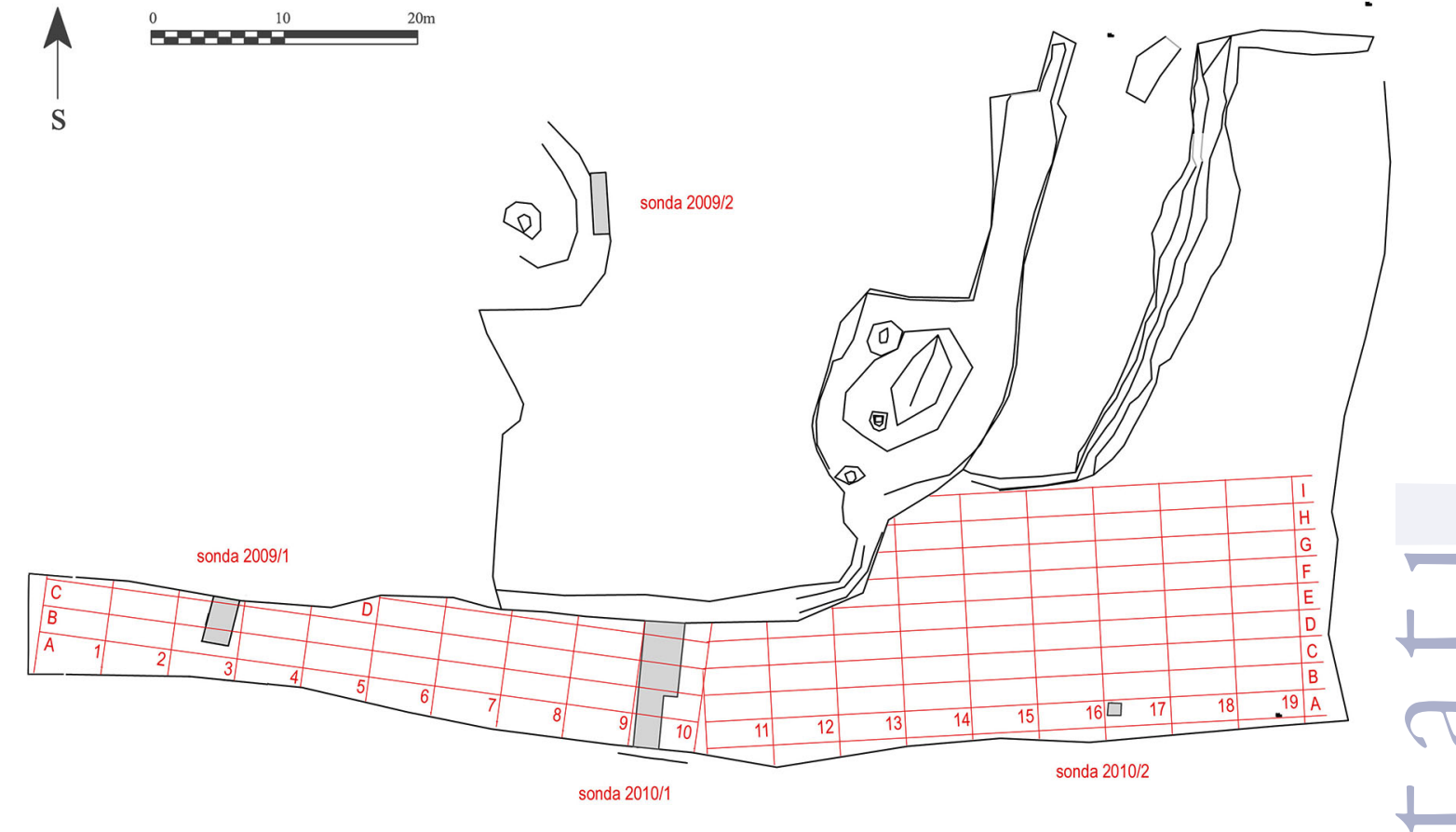

Slika 3. Kaštelir na Kortami, raziskave 2008-2010, območje ekstenzivnega pregleda z prostorsko razdelitvijo zbiralnih enot in lokacija sonde (pripravil A. Ogorelec, arhiv IAD UP FHŠ).

Prva sondiranja na vrhu in na pobočjih Kaštelirja je leta 1956 izvedla kustodinja tedanjega Mestnega muzeja Piran Elica Boltin-Tome. Pri tem je našla bronasto zapestnico rombičnega preseka, ploščat prstan s presegajočimi konci ter lok bronaste certoške fibule, več kosov žlindre in manjše kose hišnega lepa iz železne dobe. Med ostanki rimske materialne kulture pa dele amfor, opek, železne žeblje s polkrožno odebeljeno glavico 7 . Leta 1957 so v celoti izkopali, že v prejšnjem letu deloma izkopan rimski grob z oljenko, posodjem, stekleničkami in od ognja poškodovani bronasti strigilis z deli bronaste posodice ${ }^{8} . \mathrm{Z}$ arheološkimi zaščitnimi in raziskovalnimi izkopavanji je Boltin-Tome nadaljevala tudi v letih 1960 in $1962 \mathrm{z}$ večjo sondo na srednjem prečnem nasipu, da bi ugotovila tehnike gradnje in čas nastanka nasipa. Glavni del prazgodovinske nasel-

7 Elica Boltin, "Arheološke najdbe na Kaštelirju nad Kortami," Arheološki vestnik 9-10/3-4 (1958-59): 237; Elica Boltin, "Kaštelir nad Kortami," Varstvo spomenikov 7 (1958-59): 279. 293.

bine naj bi bil, glede na vse dotedanje raziskave, na zahodnem delu gradišča. Skladno s to ugotovitvijo je severni prerez prečnega nasipa pokazal, da je zahodni del nasipa bolje ohranjen od vzhodnega ${ }^{9}$. Detajlna analiza in reinterpretacija izsledkov raziskav Elice Boltin Tome je nadrobno predstavljena že drugje ${ }^{\mathrm{IO}}$, zato je na tem mestu ne bomo ponovno obnavljali.

Med leti 2008-20Io so potekale na območju Kaštelirja raziskovalne dejavnosti v sklopu delovanja Inštituta za dediščino Sredozemlja UP. Leta 2008 je potekalo čiščenje parcel (odstranitev rastja), čiščenje kamnitih struktur in foto-dokumentiranje stanja na parceli št. 1706 in I705 k.o. Dvori nad Izolo (sl. 2).

V letu 2009 je bilo v okviru študijske prakse (UP FHŠ OAD) izvedeno dokumentiranje (opisno, fotografsko) ohranjenosti kamnitih struktur po celotnem Kaštelirju, izkopani sta

\footnotetext{
Sakara Sučevič, Prazgodovinska keramika med Miljskim zalivom in porečjem Mirne.

Sakara Sučevič, Prazgodovinska keramika med Miljskim zalivom in porečjem Mirne.
} 


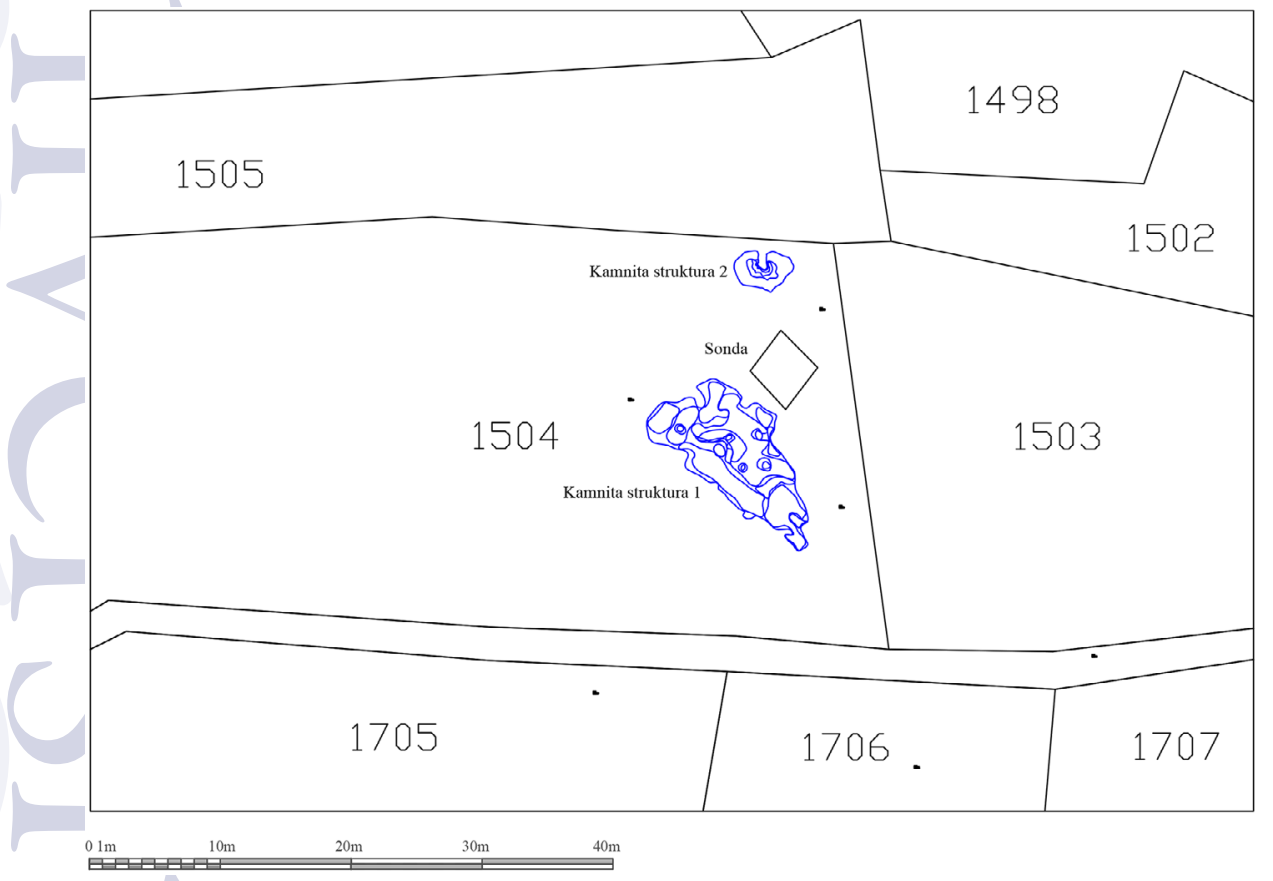

Slika 4. Kaštelir na Kortami, lokacije arheološke testne sonde, kamnite strukture/groblje I in kamnite strukture $2 \mathrm{v}$ katastrskem načrtu (pripravil A. Ogorelec, arhiv IAD UP FHŠ).

bili tudi dve testni sondi pod vodstvom Maše Sakara Sučević (UP IDS). Sonda I/2009 na mestu divjega vkopa $\mathrm{v}$ zahodnem delu parcele 1706 k.o. Dvori nad Izolo in sonda $2 / 2009$ ob vznožju gomile 2 na parceli 1705 k.o. Dvori nad Izolo. V letu 2010 pa je bil izveden ekstenzivni površinski pregled na južnem delu parcele 1706 k.o. Dvori nad Izolo, v obsegu $100 \mathrm{x}$ Io metrov in zbiralnih enotah enote $5 \times 2 \mathrm{~m}$ ter zaščitne terenske raziskave v obliki sondiranja (sl. 3 ).

Sonda v velikosti cca. 3 x $10 \mathrm{~m}$ je potekala prečno na rob terase. Izkopavanja so na dan prinesla številno prazgodovinsko in rimskodobno keramiko in bronasto figurico psa, bronasto fibulo srednjelatenske sheme in jantarno jagodo $^{\text {II }}$. Stratigrafikacija plasti je pokazala, da je bilo najdišče uničeno že ob prvem terasiranju, ki naj bi se zgodilo v začetku 20. stol. Le na južnem delu sonde, kjer teren strmo pada, se je ohrani-

I I Maša Sakara Sučević, Andrej Preložnik in Aleš Ogorelec, Preliminarno poročilo o zascitnih arheoloskih raziskavah na Kastelirju nad Kortami, parc. śt. I706, k.o. Dvori nad Izolo 2.4.-21.4.2010, (Koper: UP ZRS IDS, 2010). lo domnevno tlakovanje in nekaj jam za stojke, ki pa jih ni bilo moč datirati. Vse ostale plasti so vsebovale premešano gradivo ${ }^{12}$.

\section{Rezultati arheološkega testnega sondiranja v letu 2014}

Arheološke raziskave v letu 2014 so se izvajale na območju Korte - arheološko najdišče Kaštelir pri Čedljah (EŠD 7238), v obliki arheološkega testnega sondiranja $\mathrm{z}$ namenom preverbe stratifikacije ohranjenega arheološkega zapisa na najvišjem platoju nekdanje prazgodovinske naselbine. Sonda, v velikosti 4 × $4 \mathrm{~m}$, je bila zakoličena na parc. št. I504, k.o. Dvori nad Izolo, tik ob vznožju kamnite strukture I (groblje) (sl. 4), kar naj bi omogočilo boljši vpogled v stratificiranost arheološkega depozita na tem delu Kaštelirja, hkrati pa omogočilo podrobnejšo oceno arheološkega potenciala najdišča.

I2 Maša Sakara Sučević, Andrej Preložnik in Aleš Ogorelec, Preliminarno poročilo o zaščitnih arheoloških raziskavah na Kaštelirju nad Kortami, parc. št. 1706, k.o. Dvori nad Izolo 2.4.-21.4.2010 (Koper: UP ZRS IDS, 2010). 
Območje, izbrano za testno sondiranje, v preteklosti ni bilo podvrženo intenzivni kmetijski dejavnosti, zato je bilo pričakovati, da bo na tem delu arheološki zapis ohranjen najbolj celostno. Sondiranje je potekalo na ožjem območju kamnite strukture I, kjer je bilo dosedanje poznavanje stratifikacije arheoloških plasti Kaštelirja dejansko tudi najmanjše. Izkopno polje je bilo locirano severno od poti, ki vodi vzdolžno po Kaštelirju. Območje sonde je bilo pred našim posegom zaraščeno z nižjimi drevesi, podrastjo in zatravljeno.

Sondo smo locirali ob severovzhodni, še vidni rob kamnite strukture I. S pomočjo analize stratifikacije plasti ob vznožju kamnite strukture smo želeli pridobiti boljši vpogled v relativni stratigrafski odnos med še vidno kamnito strukturo in evidentiranimi arheološkimi plastmi, kar bi lahko pripomoglo $\mathrm{k}$ pojasnjevanju nastanka omenjene kamnite strukture, kakor tudi njeni časovni opredelitvi.

Sonda je bila postavljena na poševno območje, tik ob vidnemu robu kamnite strukture, katero se je končalo z manjšo kotanjo na njenem severnem delu. Samo površje območja sonde je bilo pred posegom neravno, kar je kazalo na to, da se pod površjem tudi na tem delu najverjetneje nahajajo plasti kamenja in lomljencev. Pri postavitvi sonde se je bilo potrebno prilagajati $\check{s}$ e rastju in večjim, vidnim kamnitim ploščam, zato ni imela povsem pravokotne oblike. Sonda je bila razdeljena v štiri kvadrante, velikosti 2 x 2 m, označeme od kv. I - do kv. 4.

\section{Metodologija in potek raziskave}

Metodologija terenskih raziskav je bila pogojena s standardi arheoloških raziskav, predvidenimi za testna sondiranja ${ }^{13}$, se pravi, stratigrafsko so se odstranjevale arheološke plasti in zemljina, grajene arheološke ostaline pa so se ohranjale »in situ«. Ker so se v jugozahodnem delu sonde elementi kamnite strukture 1 pojavili že tik pod travnato rušo, smo jih na tem delu obranjali nedotaknjene. $\mathrm{V}$ dogovoru s konservatorjem smo v kamnito strukturo I posegli le na zahodnem

I3 Pravilnik o arheoloških raziskavah (Ur.l. RS, št. 3/2013). delu sonde $\mathrm{v}$ skupni širini $\mathrm{I}, 3 \mathrm{~m}$, $\mathrm{z}$ namenom preverbe njene notranje zgradbe in pa stratifikacije plasti pod samo kamnito strukturo. Dokumentacija je obsegala postopke (geodetsko, fotografsko in opisno dokumentiranje evidentiranih plasti in arheoloških ostalin), ki so predvideni s strokovnimi standardi arheoloških raziskav.

\section{Stratifikacija plasti in arheološke ostaline na območju sonde}

Arheološke raziskave smo pričeli z odstranjevanjem travnate ruše (SE I), ki je bila tanka, do o,os cm debela, temno rjava plast glinenega melja, prekoreninjena, sestavljena iz preperela humusa s številnim rastjem. Plast je vsebovala odlomke rimskodobne keramike in recentne predmete. Pod travnato rušo smo v južnem delu sonde evidentirali elemente kamnite strukture I, v severnem delu pa smo naleteli na stratifikacijo plasti, ki so se odložile tik ob njej.

Elementi kamnite strukture I so obsegali dve zgostitvi kamenja, sestavljeni iz večjih kamnitih plošč in lomljencev peščenjaka velikosti od $30 \times 20 \mathrm{~cm}$ do $130 \times 60 \mathrm{~cm}$ (označeni kot SE 2). Prva zgostitev kamenja v obliki pasu se je nahajala na sredini sonde $\mathrm{v}$ širini $\mathrm{I}, 30 \mathrm{~m}$, druga pa ob severnem robu izkopnega polja sonde v velikosti I X I,I m. Kamni so ležali tesno skupaj in so bili interpretirani kot zunanji venec kamnite strukture I. Južno od te zgostitve je ležala plast kamnov in lomljencev peščenjaka velikosti od Io x Io do 15 X 20 cm, označena s SE 4. Kamenje je ležalo v zgornjem delu pobočja v širini I, $6 \mathrm{~m}$. Prostor med kamni je bil zapolnjen $\mathrm{z}$ rjavo glineno meljasto, humusno prstjo, ki je bila podobna SE 3 (sl. s).

Kamnita struktura i je ležala na rimskodobni plasti SE 16, katera je evidentirana kot plast temno rjavega glinenega melja, ki je vsebovala odlomke rimskodobne keramike, redke odlomke prazgodovinske keramike, kosti, školjke in redek gradbeni material. Plast je vsebovala tudi precej kamenja manjših dimenzij, peščenjaka in fliša nepravilnih in pravilnih oblik, nekateri med njimi so nekateri tudi ožgani. Plast lahko označimo za ruševinsko plast z več kamenja. Pod 


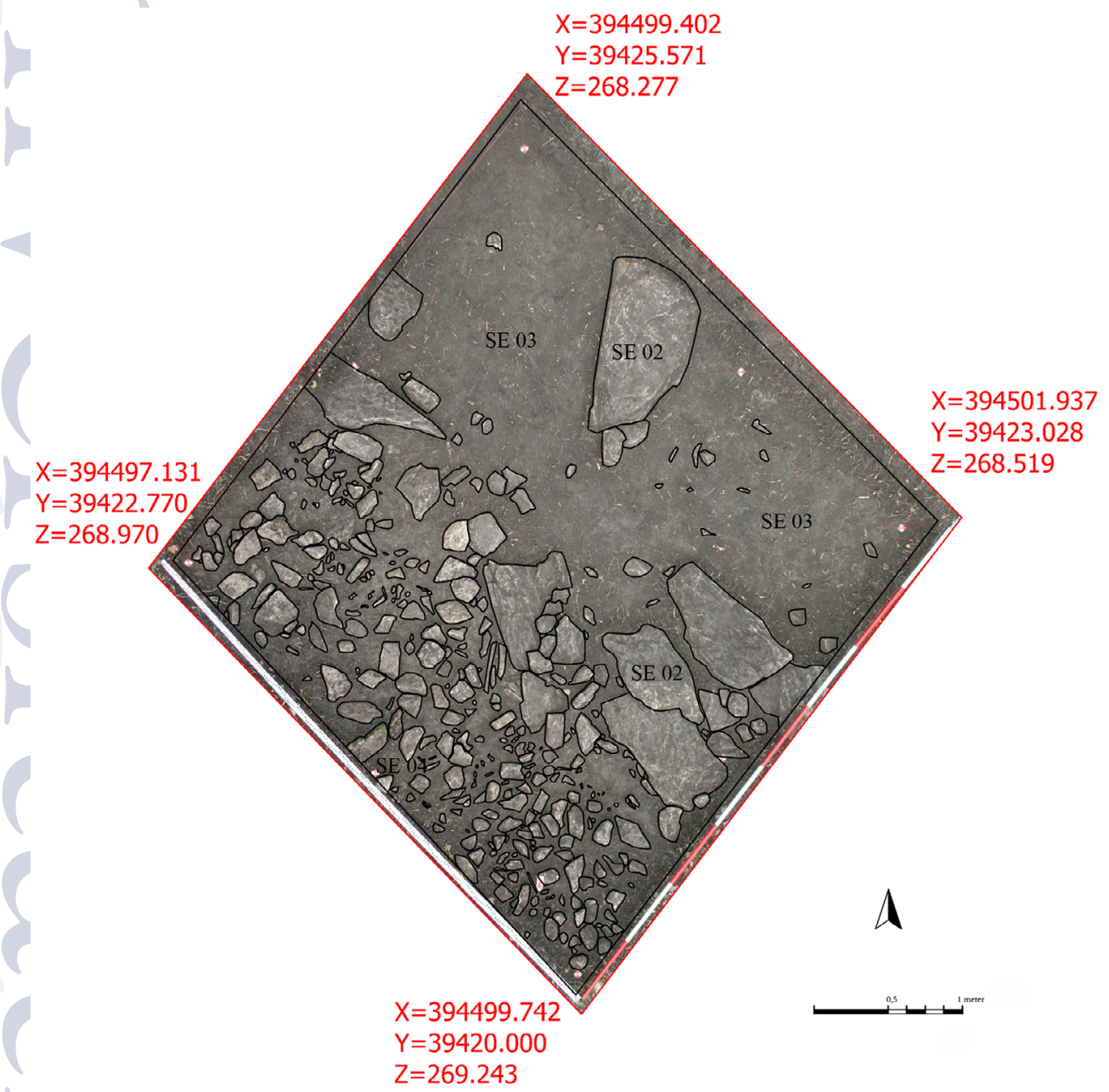

Slika s. Kaštelir na Kortami, sonda I, georeferenciran kompozitni foto-tloris plasti in arheoloških ostalin po odstranitvi travnate ruše (foto: A. Ogorelec, arhiv IAD UP FHŠ).

njo je ležala rimskodobna plast (SE i 4), sestavljena iz zelo temno sivega glinenega melja, ki je vseboval veliko količino sicer močno razdrobljene rimskodobne keramike, nekaj odlomkov prazgodovinske keramike, kosti, školjke ter kamnito kocko, kamnit izvrtek in 3 odlomke kamnitih žrmelj (sl. 6). Plast SE I4 se je nahajala po celotnem raziskanem delu sonde, tudi v njenem severozahodnem delu in je ležala neposredno na geološki osnovi ( $S E$ I5). Kamni peščenjaka v plasti SE 14 so po večini velikosti do 8 x 5 $\mathrm{cm}$. Manj kamenja je bilo v severnem delu plasti, več pa v bližini obeh kamnitih grobelj $\mathrm{SE}_{4}$ in
I2. V plasti je bila odkita izjemna količina polžev in manj školjk. Material v severozahodnem delu sonde bolj razdrobljen (odlomki do $2 \mathrm{~cm}$ pogostejši). Plast je bila debela do o,15 m. Plast lahko interpretiramo kot ostalino rimskodobne kulturne plasti.

V severovzhodnem delu sonde je pod travnato rušo ( $\mathrm{SE}$ I) po celotni širini sonde ležala rjava plast glinenega melja, prekoreninjena, humusna in gnetljiva, označena s SE 3. Plast je vsebovala rimskodobne odlomke keramike, odlomke rimskodobnega gradbenega materiala, kosti, školjke, odlomek brusa in manjše kepe ožgane gline. De- 


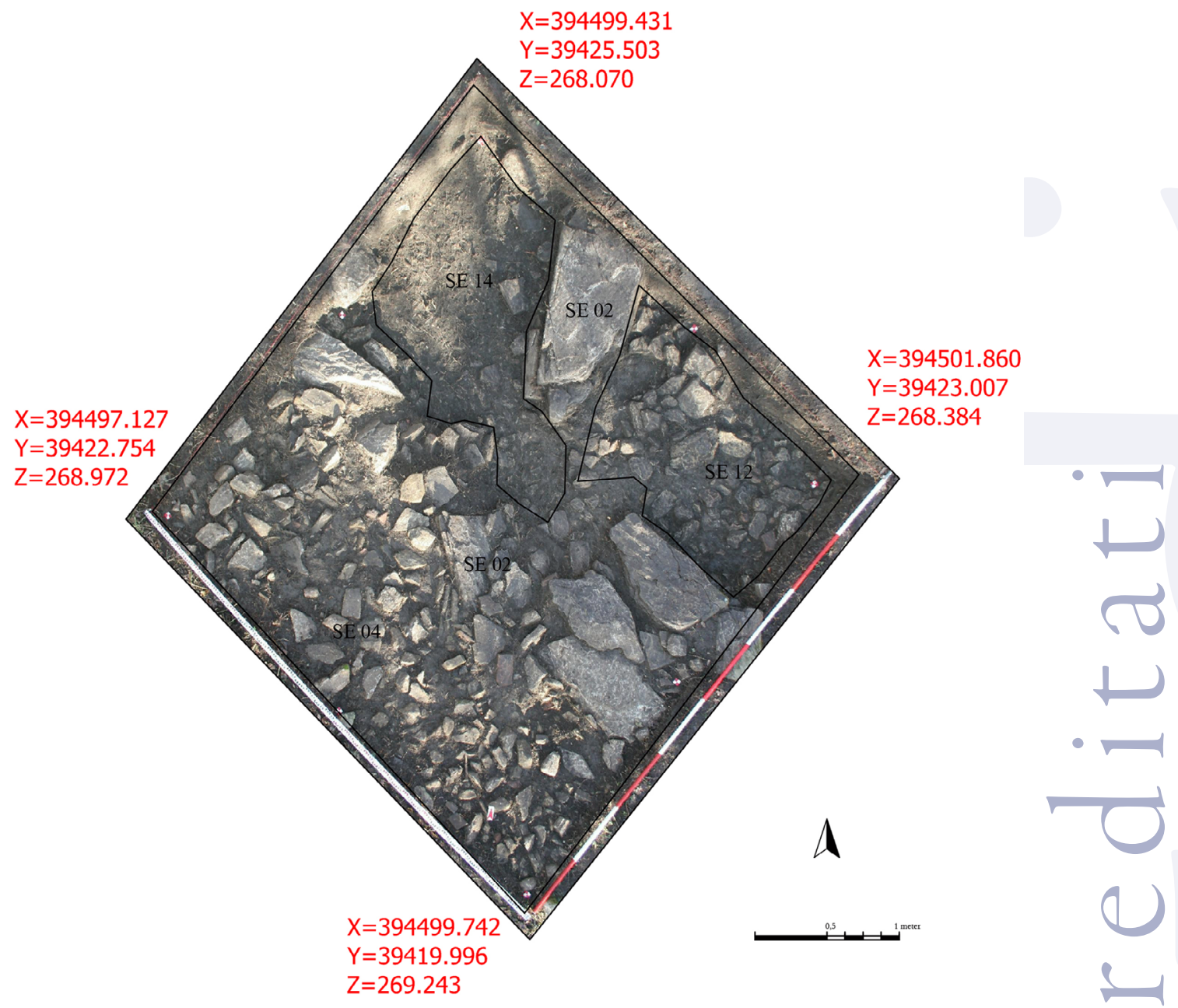

Slika 6. Kaštelir na Kortami, sonda I, georeferenciran kompozitni foto-tloris rimskodobne plasti SE 14 in arheoloških ostalin kamnite strukture I (foto: A. Ogorelec, arhiv IAD UP FHŠ).

belina plasti je znašala $0,08 \mathrm{~m}$. Odložila se je le v tem delu sonde v širini I, $5 \mathrm{~m}$. Pod njo se je v severovzhodnem delu nahajala plast SE I2, plast temno rjavega glinenega melja, ki je vsebovala tudi številno kamenje in lomljence peščenjaka, velikosti do $25 \times 20 \mathrm{~cm}$. Plast ni bila čvrsta, prostor med kamenjem pa je bil zapolnjen s temno rjavo prstjo. Plast kamenja je razčlenjena, manjše zgostitve kamenja pa so se nahajale še zahodno in južno od SE 2. Podobna je bila plasti SE I6, ki smo jo zasledili v jugozahodnem vogalu sonde pod kamnito strukturo. Tudi v tem delu sonde je bilo razvidno da SE 4 leži nad SE I2, obe pa prekrivata kamnite plošče SE 2.

V nasprotnem, severozahodnem delu sonde je pod SE 3 ležala zelo temno sivo rjava plast glinenega melja, debeline do o,Io $\mathrm{m}$ (SE 9), prekoreninjena, ki je vsebovala odlomke rimskodobne keramike in malo školjk. Pod njo je ležala tanka lisasta, zelo temno sivo rjava do sivo rjava plast glinenega melja (SE I3), ki je vsebovala odlomke rimskodobne in redke odlomke prazgodovinske keramike, kamen (brus?), kosti, školjke in en odlomke gradbenega rimskodobnega materiala. Plast SE 13 je ležala nad SE I4, ki 


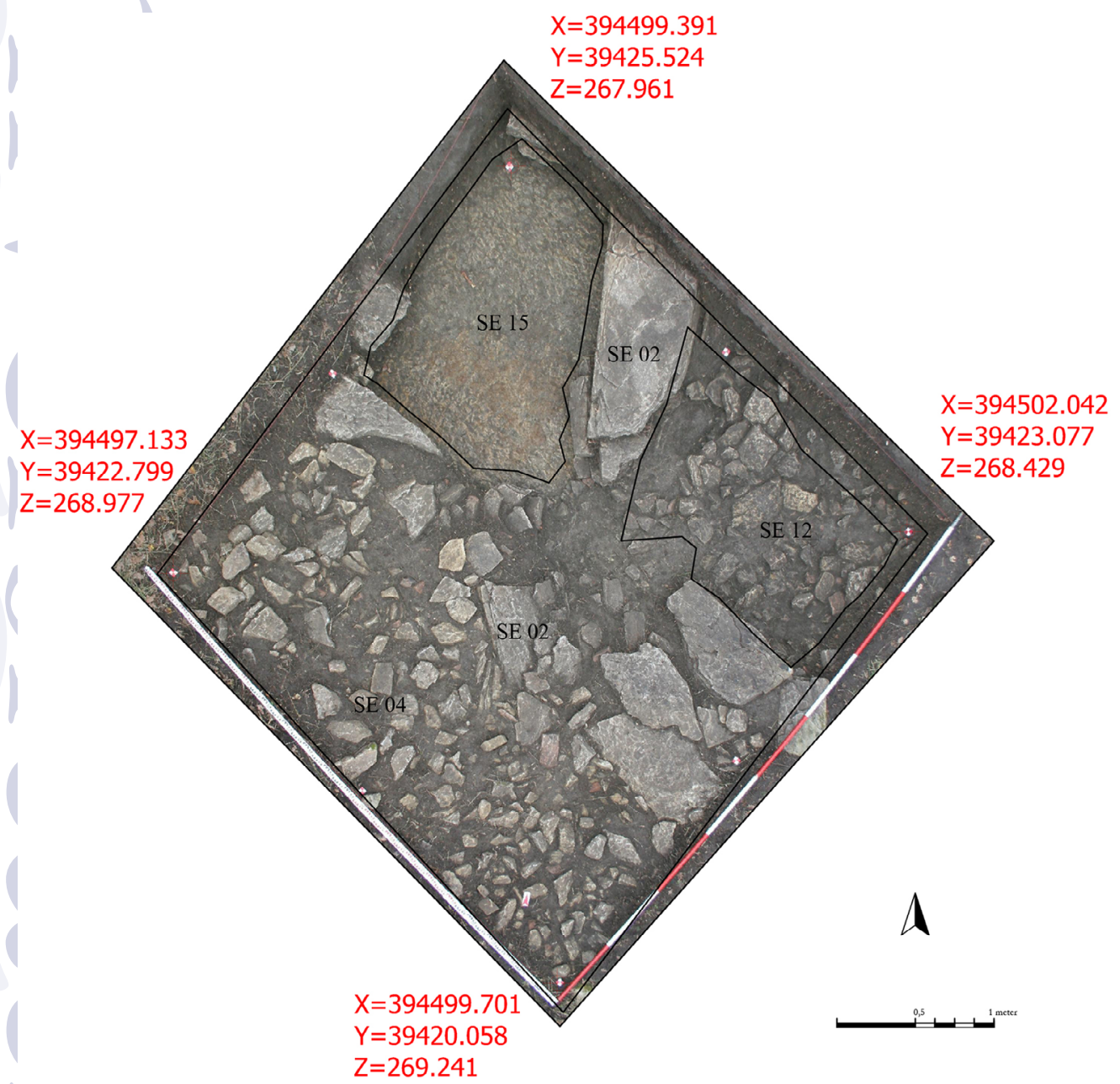

Slika 7. Kaštelir na Kortami, sonda I, georeferenciran kompozitni foto-tloris geološke osnove SE is in arheoloških ostalin kamnite strukture I (foto: A. Ogorelec, arhiv IAD UP FHŠ).

je bila interpretirana kot rimskodobna kulturna plast. Pod SE I4 pa je na celotni raziskani površini ležala SE I5, rumenkast fliš, geološka osnova (sl. 7).V geološko osnovo ni bilo vkopanih nikakršnih jam ali drugih objektov. Na raziskanem delu tudi ni bilo zaslediti intaktnih prazgodovinskih plasti. Prazgodovinske najdbe so se nagajale le v sekundarnih kontekstih.

\section{Arheološko drobno gradivo}

Arheološko gradivo, odkrito pri arheoloških raziskavah testne sonde $\mathrm{I}$, je bilo sicer dokaj številčno, vendar zelo slabo ohranjeno. Gradivo je bilo odkrito v plasteh $\mathrm{SE}_{3}, \mathrm{SE} 5, \mathrm{SE} 8$-10, $\mathrm{SE}_{13}$, SE 16, SE 4/2 in SE I 4. Gradivo je bilo oprano, sortirano in odbrano za katalogizacijo.

Katalog arheološkega drobnega gradiva po posameznih arheoloskih kontekstih

$\mathrm{V}$ katalogu predstavljamo izbor najdb $\mathrm{z}$ arheološkega najdišča Kaštelir nad Kortami, ki obsega 57 odlomkov gradiva, izdelanega iz keramike, kamna, kovine in stekla, ki po večini pripada rimskemu obdobju, nekateri odlomki pa so opredeljeni kot prazgodovinski. 
Opisi keramičnih najdb delno sledijo oblikovno - tehnološkem obrazcu, kot ga je predlagala M. Horvat ${ }^{\mathrm{I} 4}$. Predmeti so predstavljeni opisno, grafično $\mathrm{v}$ fototabelah v merilu $\mathrm{I}: 2$ (sl. 8 - II), del njih pa je bilo tudi izrisanih (sl. I2 - I4). Fotografije in izdelava fototabel je delo Aleša Ogorelca, najdbe je narisala Janja Tratnik Šumi.

Predmeti so v katalogu razporejeni po fazah, katerim pripadajo stratigrafske enote (SE), v katerih so bili najdeni, od najstarejše faze do najmlajše faze. V primeru, da SE vsebuje odlomke različnih obdobij so le-ti znotraj posamezne SE prav tako organizirani kronološko.

Opisi predmetor ${ }^{15} \mathrm{v}$ katalogu vsebujejo najdiščne podatke (SE, kv., začasna inv. št.), podatke o številu odlomkov keramike, obdobju, načinu izdelave, podatke o sestavi lončarske mase, dodelavi in barvi površine (barva določena $s$ pomočjo Munsellove barvne lestvice), načinu žganja, opis okrasa in posebnosti. Rimskodobni odlomki so dodatno opredeljeni še funkcionalno kot fino namizno posodje (tera sigilata), namizno posodje, kuhinjsko posodje in transportno posodje (amfore) ter posebne oblike (predilno vretence). Kovinski, kamniti in stekleni predmeti imajo najdiščne podatke (SE, kv., začasna inv. št.), naveden je material in kratek opis. Vsi predmeti imajo velikost podano $\mathrm{v}$ centimetrih $(\mathrm{cm})$. Za trajno hrambo gradiva je pristojen Pokrajinski muzej Koper.

I. SE I 4, sonda I/20I 4, kv. 4, zač. inv. št.

I $4 / 38$.

Odlomek ostenja prazgodovinske posode, izdelane prostoročno iz drobnozrnate lončarske mase (BCEF). Gladka površina

I4 Milena Horvat, Keramika, Tehnologija keramike, tipologija lončenine, keramični arhiv (Ljubljana: Znanstveni inštitut Filozofske fakultete, 1999)

15 Legenda: Lonćarska masa: zelo finozrnata - zrna so velikosti do o,25 $\mathrm{mm}$; finozrnata - zrna so velikosti $0,26-0,50 \mathrm{~mm}$; drobnozrnata zrna so velikosti od $0,5 \mathrm{I}-2,00 \mathrm{~mm}$, grobozrnata - zrna so velikosti od 2,01-3,00 mm, zelo grobozrnata - zrna so večja od 3,01 mm. Oznake sestavin: A - kremen, $\mathrm{B}$ - kalcijev karbonat, $\mathrm{C}$ - sljuda, D - organske snovi, E - železovi oksidi, F - glinena jedra, G - zdrobljena keramika. Okrajšave: dl. - dolžina, v. - višina, š. - širina, pr. premer, db. - debelina, u. - ustje, d. - dno, nv. - največji, SE - stratigrafska enota, kv. - kvadrant, zač. inv. št. - začasna inventarna številka. je na zunanji strani lisasta rjava $(7.5 \mathrm{YR}$ $5 / 4$ in $\left.7.5 \mathrm{YR}_{5} / 6\right)$, na notranji strani pa sivo črna (7.5YR 3/I). Žganje redukcijsko, verjetno sekundarno žgana. Na ostenju je apliciran okras ščipanega rebra. Dl. 3,4 cm, š. $3,2 \mathrm{~cm}$.

2. SE I 4, sonda I/20I 4, kv. 4, zač. inv. št. I $4 / 40$.

Odlomek ostenja z ročajem prazgodovinske posode, izdelane prostoročno iz grobozrnate lončarske mase (BCF). Gladka površina je lisasta sivo črno temno rjava (7.5 $\mathrm{YR}_{3} / 4$ in $7.5 \mathrm{YR}_{3} / \mathrm{I}$ ). Žganje nepopolno oksidacijsko. Dl. 4,6 $\mathrm{cm}$, š. $4,5 \mathrm{~cm}$, ročaj - š. $3, \mathrm{I} \mathrm{cm}, \mathrm{db}$. I,9 cm.

3. SE I 4 , sonda I/20I 4 , kv. I, zač. inv. št. I $4 /$ I. Fino namizno posodje, odlomek ustja z ostenjem rimskodobne posode, izdelane na lončarskem vretenu iz zelo finozrnate lončarske mase (CE). Gladka, poškodovana površina je rdečkasta (rožnata) (7.5YR 7/4, osnovna površina), • na zunanji in notranji strani ohranjen poškodovan sivo črn premaz $(2.5 \mathrm{Y} 2.5 / \mathrm{I})$ ? Žganje oksidacijsko. Na zunanji in notranji strani vzporedni vodoravni kaneluri. Dl. $2,0 \mathrm{~cm}$, v. $\mathrm{I}, 4 \mathrm{~cm}$.

4. SE I 4, sonda I/20I 4, kv. I, zač. inv. št. I 4/2. Fino namizno posodje, odlomek ustja? $\mathrm{z}$ ostenjem rimskodobne posode, izdelane na lončarskem vretenu iz zelo finozrnate lončarske mase (CE). Gladka, poškodovana površina je rdečkasta (rožnata) (7.5YR 7/4, osnovna površina), na zunanji in notranji strani slabo ohranjen sivo črn premaz (2.5Y 2.5/I). Žganje oksidacijsko. Na notranji? strani vzporedne vodoravni kanelure. Dl. $3,2 \mathrm{~cm}$, v. I,8 cm. Morda del I $4 /$ I.

5. SE I 4 , sonda I/20I 4 , kv. 4, zač. inv. št. I $4 / 35$.

Fino namizno posodje, odlomek roba ustja z ostenjem rimskodobnega krožnika, izdelanega na lončarskem vretenu iz finozrnate lončarske mase (CE). Gladka, delno poškodovana površina je svetlo rdeča 
(7.5YR 7/6, osnovna površina). Na zunanji in notranji strani poškodovan sivo črn premaz (2.5Y 2.5/I). Žganje oksidacijsko. Pr. u. $17,5 \mathrm{~cm}, \mathrm{v}, 2,5 \mathrm{~cm}$.

6. SE I 4 , sonda I/20I 4, kv. I, zač. inv. št. I4/16.

Fino namizno posodje, odlomek ostenja rimskodobne posode, izdelane na lončarskem vretenu iz zelo finozrnate lončarske mase (posamezni fini vključki) (CE). Gladka, poškodovana površina je svetlo rdeča (IOYR 6/6, osnovna površina), na zunanji in notranji strani ohranjen poškodovan sivo črn premaz $(2.5 \mathrm{Y} 2.5 / \mathrm{I})$. Žganje oksidacijsko. Dl. 4,I cm, v. 2,5 cm.

7. SE I 4 , sonda I/2OI 4 , kv. 4, zač. inv. št. I $4 / 36$.

Fino namizno posodje, odlomek ostenja rimskodobne posode, izdelane na lončarskem vretenu iz finozrnate lončarske mase (CE). Gladka, delno poškodovana površina je svetlo rdeča (7.5YR 7/6, osnovna površina). Na zunanji? strani poškodovan sivo črn premaz (7.5Y 2.5/I). Žganje oksidacijsko. Dl. 2, 4 cm, š. I, $8 \mathrm{~cm}$.

8. SE I 4 , sonda I/20I 4, kv. 4, zač. inv. št. I $4 / 37$. Fino namizno posodje, odlomek ostenja rimskodobne posode, izdelane na lončarskem vretenu iz zelo finozrnate lončarske mase (CE). Gladka, delno poškodovana površina je svetlo rdeča (7.5 YR 7/6, osnovna površina). Na zunanji in notranji strani poškodovan sivo črn premaz (2.5YR 2.5/I). Žganje oksidacijsko. Dl. $2,2 \mathrm{~cm}$, š. I, $6 \mathrm{~cm}$.

9. SE I 4 , sonda I/20I 4 , kv. 4, zač. inv. št. I $4 / 33$.

Namizno posodje, odlomek roba ustja z ostenjem rimskodobne čaše, izdelane na lončarskem vretenu z finozrnate lončarske mase (ACF). Gladka površina je sivo črna (2.5Y 2.5/I). Žganje redukcijsko. Pr. u. 7,6 $\mathrm{cm}, \mathrm{v} .1,5 \mathrm{~cm}$.

IO. SE I 4 , sonda I/20I 4 , kv. 4, zač. inv. št. $14 / 34$.
Namizno posodje, odlomek roba ustja z ostenjem rimskodobne čaše, izdelane na lončarskem vretenu iz finozrnate lončarske mase (CF). Gladka površina je svetlo rdeča (7.5YR 6/6). Žganje oksidacijsko. Dl. 3,2 $\mathrm{cm}$, š. $\mathrm{I}, 4 \mathrm{~cm}$.

II. SE I 4, sonda I/20I 4, kv. 4, zač. inv. št. I $4 / 25$.

Namizno posodje, odlomek ustja z ostenjem rimskodobne posode, izdelane na lončarskem vretenu iz finozrnate lončarske mase (CE). Gladka površina je svetlo rdeča (IoYR 6/6). Žganje oksidacijsko. Pr. u. 8,6

I2. SE I 4, sonda I/20I 4, kv. 4, zač. inv. št. I $4 / 26$.

Namizno posodje, odlomek ustja z ostenjem rimskodobne posode, izdelane na lončarskem vretenu iz finozrnate lončarske mase (CE). Gladka površina je rdečkasto svetlo rjava (7.5YR 6.5/4). Žganje oksidacijsko. Dl. $2,5 \mathrm{~cm}$, š. $1,5 \mathrm{~cm}$.

I3. SE I 4, sonda I/20I 4, kv. I, zač. inv. št. I 4/4. Namizno posodje, odlomek ročaja rimskodobne posode, izdelane na lončarskem vretenu iz finozrnate lončarske mase (ACEF). Gladka površina je bledo rjava (IoYR 7/4). Žganje oksidacijsko. Dl. $3,8 \mathrm{~cm}$, nv. š. $1,9 \mathrm{~cm}, \mathrm{nv}$. db. $0,9 \mathrm{~cm}$.

I4. SE I 4, sonda I/20I 4, kv. I, zač. inv. št. I4/I5.

Namizno posodje, odlomek trakastega ročaja rimskodobne posode, izdelan prostoročno iz finozrnate lončarske mase (CE). Gladka površina je svetlo rdeča (7.5YR 6/8). Žganje oksidacijsko. Dl. 4,7 cm, v. $2,2 \mathrm{~cm}, \mathrm{db} .0,7 \mathrm{~cm}$.

I5. SE I 4, sonda I/20I 4, kv. 4, zač. inv. št. I $4 / 30$.

Namizno posodje, odlomek dna $\mathrm{z}$ ostenjem rimskodobne posode na prstanasti nogi, izdelane na lončarskem vretenu iz finozrnate lončarske mase (CD). Gladka površina je bledo rjava ( $\mathrm{IOYR}_{7 / 4}$ ). Žganje oksidacijsko. Pr. d. 9,5 cm, v. 3,4 cm. 
I6. SE I 4, sonda I/20I 4, kv. 4, zač. inv. št. I $4 / 19$.

Kuhinjsko posodje, odlomek ustja z ostenjem rimskodobne posode, izdelane na lončarskem vretenu iz drobnozrnate lončarske mase (ABCD). Gladka površina je temno rjava (IoYR 3/I). Žganje nepopolno oksidacijsko, $v$ zadnji fazi dimljenje. Na zunanji površini sledi saj. Dl. $2, \mathrm{I} \mathrm{cm}, \stackrel{\mathrm{s}}{\mathrm{I}} \mathrm{I}, 8 \mathrm{~cm}$.

I7. SE I 4 , sonda I/20I 4 , kv. 4, zač. inv. št. I $4 / 23$.

Kuhinjsko posodje, odlomek ustja z ostenjem rimskodobne posode, izdelane na lončarskem vretenu iz drobnozrnate lončarske mase (ABC). Gladka površina je lisasto temno rjava ( $\mathrm{IOYR}_{3} / \mathrm{I}$ in $\mathrm{IOYR}_{3} / 2$ ). Žganje nepopolno oksidacijsko, v zadnji fazi dimljenje. Dl. 2,I cm, š. 2,o cm.

I8. SE I 4 , sonda I/2OI 4 , kv. 4, zač. inv. št. I $4 / 27$.

Kuhinjsko posodje, odlomek ostenja rimskodobne posode, izdelane na lončarskem vretenu iz drobnozrnate lončarske mase (ABC). Gladka površina je lisasto temno rjava ( $\operatorname{IoYR}_{3} / \mathrm{r}$ in $\operatorname{IoYR}_{3} / 2$ ). Žganje nepopolno oksidacijsko, v zadnji fazi dimljenje. Ostenje posode je okrašeno $\mathrm{z}$ vodoravnim glavničenjem. $\mathrm{Dl}$. 4,I cm, š. $3, \mathrm{I} \mathrm{cm}$.

19. SE I 4 , sonda I/20I4, kv. 4, zač. inv. št. I $4 / 29$.

Kuhinjsko posodje, odlomek dna ostenja rimskodobne posode, izdelane na lončarskem vretenu iz drobnozrnate lončarske mase (s posameznimi grobimi vključki)(ABCEG). Groba površina je zunaj lisasto rjava in temno rjava $(7.5 \mathrm{YR}$ $5 / 4$ in $7.5 Y R \quad 4 / 2$ ) in znotraj svetlo rdeča (7.5YR 6/6). Žganje oksidacijsko. Pr. d. 7,I cm, v. $2,8 \mathrm{~cm}$.

20. SE I 4 , sonda I/20I 4 , kv. I, zač. inv. št. I $4 / 3$. Kuhinjsko posodje, odlomek roba z ostenjem rimskodobnega pokrova, izdelanega na lončarskem vretenu iz drobnozrnate lončarske mase (ACEF).
Groba površina je rjava (IoYR 5/3 zunaj, 7.5YR 5/6 znotraj). Žganje oksidacijsko. $\mathrm{Na}$ zunanji površini temnejše barve verjetno zaradi uporabe (zadimljeno). Na zunanji stran tik nad robom vodoravna kanelura. Dl. $3,3 \mathrm{~cm}$, š. $\mathrm{I}, 6 \mathrm{~cm}$.

2I. SE I 4 , sonda I/20I 4 , kv. 4, zač. inv. št. I $4 / 24$.

Kuhinjsko posodje, odlomek roba z ostenjem rimskodobnega pokrova, izdelanega na lončarskem vretenu iz drobnozrnate lončarske mase (ABC). Gladka površina je temno rjava ( IOYR $_{3} / \mathrm{I}$ ). Žganje nepopolno oksidacijsko, v zadnji 。 fazi dimljenje. Dl. $2,2 \mathrm{~cm}$, š. I, $5 \mathrm{~cm}$.

22. SE I 4 , sonda I/20I 4 , kv. I, zač. inv. št. I $4 / 8$. Transportno posodje, odlomek ostenja/ rame rimskodobne amfore (verjetno Dressel 2-6), izdelane na lončarskem vretenu iz finozrnate lončarske mase (s posameznimi drobnimi vključki) (CEF). Gladka površina je svetlo rjava (7.5YR 6/4). Žganje oksidacijsko. Dl. $4,8 \mathrm{~cm}$, š. $8, \mathrm{I} \mathrm{cm}$, db. I cm.

23. SE I 4 , sonda I/20I 4 , kv. 4, zač. inv. št. I $4 / 28$.

Namizno posodje (?), odlomek prstanastega dna rimskodobne posode, izdelane na lončarskem vretenu iz finozrnate lončarske mase (pogosti drobni vključki) (CF, večji vključki E). Gladka, poškodovana površina je rumenkasto svetlo rdeča (IOYR 6.5/6). Žganje oksidacijsko. Dl. 5, $6 \mathrm{~cm}$, š. $3,6 \mathrm{~cm}$.

24. SE I 4 , sonda I/20I 4, kv. I, zač. inv. št. I 4/7. Transportno posodje, odlomek poškodovanega ročaja $\mathrm{z}$ ostenjem rimskodobne posode, verjetno amfore, izdelane na lončarskem vretenu iz finozrnate lončarske mase (s posameznimi drobnimi in grobimi vključki) (BCEF). Gladka površina je bledo rjava (IoYR 6.5/4). Žganje oksidacijsko. Dl. $8,5 \mathrm{~cm}$, š. $8,4 \mathrm{~cm}$, ročaj - š. $4,2 \mathrm{~cm}, \mathrm{db} .2,9 \mathrm{~cm}$.

25. SE I 4 , sonda I/20I 4, kv. 3, zač. inv. št. I4/12. 
Transportno? posodje, odlomek ročaja z ostenjem rimskodobne posode, izdelane na lončarskem vretenu iz finozrnate lončarske mase (CE). Gladka površina je bledo rjava (IoYR 6.5/4). Žganje oksidacijsko. Dl. 6,I $\mathrm{cm}$, š. $6,4 \mathrm{~cm}$, ročaj - š. $6,0 \mathrm{~cm}, \mathrm{db} .2, \mathrm{I} \mathrm{cm}$.

26. SE I4, sonda I/20I 4, kv. I, zač. inv. št. I $4 / 14$.

Transportno posodje, odlomek ročaja rimskodobne posode, verjetno amfore, izdelane na lončarskem vretenu iz drobnozrnate lončarske mase (posamezni grobi vključki) (CEF). Gladka površina je bledo rjava (IOYR 8/4). Žganje oksidacijsko. Dl. $7,5 \mathrm{~cm}$, nv. š. $7,7 \mathrm{~cm}$, nv. db. 5,2 cm.

27. SE I 4 , sonda I/20I 4, kv. I, zač. inv. št. I 4/6. Transportno posodje, odlomek ročaja rimskodobne posode, verjetno amfore, izdelane na lončarskem vretenu iz drobnozrnate lončarske mase (posamezni grobimi vključki) (BCEF). Gladka površina je bledo rjava (roYR 6.5/4). Žganje oksidacijsko. Dl. 7,5 cm, š. 4,7 cm, db. 3,2 $\mathrm{cm}$.

28. SE I 4 , sonda I/20I 4, kv. I, zač. inv. št. I 4/9. Transportno posodje, odlomek poškodovanega ročaja $\mathrm{z}$ ostenjem rimskodobne posode, verjetno amfore, izdelane na lončarskem vretenu iz finozrnate lončarske mase (s posameznimi drobnimi in grobimi vključki) (CEFG). Gladka površina je bledo rjava (roYR 8/4). Žganje oksidacijsko. Dl. 4,2 cm, š. 7,0 cm, ročaj - š. $4,8 \mathrm{~cm}, \mathrm{nv}$. db. $2,7 \mathrm{~cm}$.

29. SE I 4 , sonda I/20I 4 , kv. I, zač. inv. št. I4/IO.

Transportno posodje, odlomek ročaja rimskodobne posode, verjetno amfore, izdelane na lončarskem vretenu iz finozrnate lončarske mase (s pogostimi drobnimi in grobimi vključki) (BCEF). Groba površina je svetlo rjava (IOYR 6/4). Žganje oksidacijsko. Dl. 8,I cm, š. 5,2 cm, nv. db. 3,I cm.
30. SE I 4 , sonda I/2OI 4, kv. I, zač. inv. št. I $4 /$ II.

Transportno posodje, odlomek ročaja rimskodobne posode, verjetno amfore, izdelane na lončarskem vretenu iz finozrnate lončarske mase (posamezni drobnimi vključki) (BCEF). Gladka površina je svetlo rdeča (7.5YR 6/6). Žganje oksidacijsko. Dl. 9,6 cm, nv. š. 5,6 cm, nv. db. $3,2 \mathrm{~cm}$.

3I. SE I 4, sonda I/20I 4, kv. I, zač. inv. št. I4 $/ 13$.

Transportno posodje, odlomek ročaja rimskodobne posode, verjetno amfore, izdelane na lončarskem vretenu iz drobnozrnate lončarske mase (CE). Gladka površina je bledo rjava (IoYR 7.5/4). Žganje oksidacijsko. Dl. 9, o cm, nv. š. 5,6 cm, nv. db. $2,9 \mathrm{~cm}$.

32. SE I 4 , sonda I/2OI $4, \mathrm{kv.} \mathrm{4}$, zač. inv. št. I $4 / 4 \mathrm{I}$.

Transportno posodje, odlomek ročaja rimskodobne posode, verjetno amfore, izdelane na lončarskem vretenu iz finozrnate lončarske mase (posamezni drobnimi in grobimi vključki) (CEF). Gladka površina je bledo rjava (IoYR 7.5/4). Žganje oksidacijsko. Dl. 9,5 cm, nv. š. $4,5 \mathrm{~cm}, \mathrm{nv}$. db. $2,5 \mathrm{~cm}$.

33. SE I 4 , sonda $\mathrm{I} / 20 \mathrm{I} 4, \mathrm{kv} .4$, zač. inv. št. I4/39.

Transportno posodje, odlomek dna $s$ poškodovanim zatičem $\mathrm{z}$ ostenjem rimskodobne posode, verjetno amfore, izdelane na lončarskem vretenu iz drobnozrnate lončarske mase (CEF). Gladka površina je bledo rjava (IOYR 7/4). Žganje oksidacijsko. Nv. dl. I0,3 cm, v. 3,3 $\mathrm{cm}, \mathrm{db}$. zatiča $2,6 \mathrm{~cm}$.

34. SE I 4 , sonda I/2OI 4 , kv. 4, zač. inv. št. I $4 / 3$ I.

Odlomek predilnega vretenca, izdelanega prostoročno iz drobnozrnate lončarske mase (CEG). Gladka površina je svetlo rjava (IoYR 6/4). Pr. 3,2 cm, v. 2,6 cm, pr. luknje $0,6 \mathrm{~cm}$. 
35. SE I 4 , sonda I/20I 4, kv. I, zač. inv. št. I 4/5. Odlomek predilnega vretenca, izdelanega prostoročno iz drobnozrnate lončarske mase (BCE). Gladka površina je svetlo rjava (IoYR 6/4). Pr. 3,7 cm, v. 2,5 cm, pr. luknje $0,6 \mathrm{~cm}$.

36. SE I 4 , sonda I/20I 4 , kv. I, zač. inv. št. I $4 / 20$.

Del kamnitih žrmelj, grobozrnati apnenec.

Dl. $8,0 \mathrm{~cm}$, nv. š. $4,8 \mathrm{~cm}$, nv. db. 4,0 $\mathrm{cm}$.

37. SE I 4 , sonda I $/ 2014$, kv. 3, zač. inv. št. I $4 / 2$ I.

Del kamnitih žrmelj, verjetno tekač, grobozrnata kamenina. Spodnja? stranica močno obrabljena/gladka in ravna. $\mathrm{Dl}$. Io, $6 \mathrm{~cm}$, nv. š. $7,2 \mathrm{~cm}$, nv. db. 4,3 cm.

38. SE I 4 , sonda I $/ 20 I_{4}$, kv. 4, zač. inv. št. I $4 / 22$.

Del kamnitih žrmelj, tekač, grobozrnati peščenjak. Klinaste oblike, slabo ohranjen robnik. Dl. I 4,5 cm, š. $8,3 \mathrm{~cm}$, nv. db. 9,2 $\mathrm{cm}$.

39. SE I 4, sonda I/20I 4, kv. 4, zač. inv. št. $14 / 32$.

Kamnita kocka, drobnozrnati peščenjak svetlo rumenkasto rjave barve (2.5Y 6/4). Dl. stranic med 2, 4 in 2,7, v. med 2,0 in 2,2 $\mathrm{cm}$.

40. SE I 4 , sonda I/20I 4 , kv. 4, zač. inv. št. I4/17.

Kamnit valjast izvrtek, ovalnega preseka, drobnozrnati peščenjak svetlo rjave barve (7.5YR 6/4), morda sekundarno ožgan. Dl. I, I cm, š. $0,9 \mathrm{~cm}$, V. I, $7 \mathrm{~cm}$.

4I. SE I 4, sonda I/20I 4, kv. 4, zač. inv. št. $14 / 18$.

Kos svinca, nepravilne oblike. Dl. 2,5 cm, š. $2,3 \mathrm{~cm}, \mathrm{db} .0,2 \mathrm{~cm}$, teža $16 \mathrm{~g}$.

42. SE I6, sonda I/20I 4, kv. I, zač. inv. št. I6/2. Transportno posodje, odlomek ostenja/ rame rimskodobne amfore (verjetno Dressel 2-6), izdelane na lončarskem vretenu iz finozrnate lončarske mase (s posameznimi grobimi vključki) (CEF). Gladka, poškodovana površina je bledo rjava (IoYR 7.5/4). Žganje oksidacijsko. $\mathrm{Na}$ zgornjem delu ramena verjetno nastavek za ročaj. Dl. 9,4 cm, š. 5,4 cm, nv. š (rame) 24 $\mathrm{cm}$.

43. SE I6, sonda I/20I 4 , kv. I, zač. inv. št. I6/I. Odlomek rimskodobne tegule, iz finozrnate lončarske mase (s pogostimi drobnimi in grobimi vključki) (CEF). Gladka površina je bledo rjava (IoYR 7.5/4). Žganje oksidacijsko. Dl. II,9 cm, š. $7,4 \mathrm{~cm}$, v. $6,5 \mathrm{~cm} \mathrm{db} .3,2 \mathrm{~cm}$.

44. SE I3, sonda I/20I4, kv. 4, zač. inv. št. I3/4. Namizno posodje, odlomek dna rimskodobne posode na prstanasti nogi, izdelane na lončarskem vretenu iz finozrnate lončarske mase (posamezni drobni vključki) (CEF). Gladka površina je na zunanji strani bledo rumena $(2.5 \mathrm{Y} 7 / 3)$, na notranji strani pa bledo rjava (IoYR 7/4). Žganje oksidacijsko. Dl. 3,7 cm, š. I,9 $\mathrm{cm}$.

45. SE I3, sonda I/20I 4 , kv. 4, zač. inv. št. I3/2. Kuhinjsko posodje, odlomek ostenja rimskodobne posode, izdelane na lončarskem vretenu iz drobnozrnate lončarske mase (BEG). Gladka površina je na zunanji strani lisasta sivo temno rjava (IOYR 4/I in IO YR 4/2), na notranji pa rumena (2.5Y 6/4). Ž ganje redukcijsko. $\mathrm{Na}$ odlomku je okras poševnih pasov kanelur, motiv ribje kosti. Dl. $3,9 \mathrm{~cm}, \mathrm{~s}^{3}, 3,8 \mathrm{~cm}$.

46. SE I3, sonda I/20I 4, kv. 3, zač. inv. št. I3/5. Kuhinjsko posodje, odlomek dna z ostenjem rimskodobne posode, izdelane na lončarskem vretenu iz drobnozrnate lončarske mase (BCD). Gladka površina je zunaj lisasta svetlo rdeča, svetlo rjava in sivo črna (7.5YR 6/6, 10YR 3/2 ter 2.5Y 6/3), znotraj pa svetlo rdeča (7.5YR 6/6). Žganje redukcijsko, v končni fazi oksidacijsko. $\mathrm{Na}$ zunanji površini sledi saj, dno sekundarno žgano?. Dl. $3,3 \mathrm{~cm}$, š. $1,9 \mathrm{~cm}$.

47. SE I3, sonda I/20I 4, kv. 4, zač. inv. št. I3/3. Kuhinjsko posodje, odlomek dna z ostenjem rimskodobne posode, izdelane na lončarskem vretenu iz drobnozrnate 
lončarske mase (BCDF). Gladka površina je temno rjava (IoYR 3/I). Žganje redukcijsko. Dl. $2, \mathrm{I} \mathrm{cm}$, š. I, $4 \mathrm{~cm}$.

48. SE I3, sonda I/2OI 4, kv. 4, zač. inv. št. I3/I. Kuhinjsko posodje, odlomek roba z ostenjem rimskodobnega pokrova, izdelane na lončarskem vretenu iz drobnozrnate lončarske mase (ABCDE). Gladka površina je rjava ( 5 YR s/8). Žganje oksidacijsko. Na robu sledi zadimljenosti. Dl. $4,7 \mathrm{~cm}, \mathrm{~s} .2,0 \mathrm{~cm}$.

49. SE $\mathrm{I}_{3}$, sonda I/20I $4, \mathrm{kv} .3$, zač. inv. št. I3/6. Ovalen ploščat kamnit predmet, morda utež (?). Finozrnati peščenjak, svetlo rumenkasto rjave barve (2.5Y 6/3). Dl. 7,I $\mathrm{cm}$, š. $5,1 \mathrm{~cm}, \mathrm{db} .2,0 \mathrm{~cm}$.

50. $\mathrm{SE}_{3}$, sonda I/20I 4, kv. 3, zač. inv. št. 3/2. Kuhinjsko posodje, odlomek ustja z ostenjem rimskodobne posode, verjetno lonca, izdelanega na lončarskem vretenu iz drobnozrnate lončarske mase (ABCD). Groba površina je temno rjava ( IoYR $\left._{3} / \mathrm{I}\right)$.

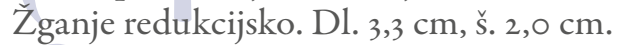

5I. SE 3 , sonda I/2OI $4, \mathrm{kv} .3$, zač. inv. št. $3 / 3$. Transportno posodje, odlomek poškodovanega ročaja rimskodobne posode, verjetno amfore, izdelane na lončarskem vretenu iz finozrnate lončarske mase (s posameznimi drobnimi in grobimi vključki) (CEF). Gladka površina je bledo rjava (roYR 6/4).Žganje oksidacijsko. Dl. $5,2 \mathrm{~cm}$, nv. š. $6,4 \mathrm{~cm}, \mathrm{nv}$. db. $3,4 \mathrm{~cm}$.

52. $\mathrm{SE}_{3}$, sonda $\mathrm{I} / 20 \mathrm{I}_{4}, \mathrm{kv} .3$, zač. inv. št. 3/4. Transportno posodje, odlomek poškodovanega ročaja rimskodobne posode, verjetno amfore, izdelane na lončarskem vretenu iz finozrnate lončarske mase (s posameznimi drobnimi in grobimi vključki) (CEF). Gladka površina je svetlo rjava (7.5YR 6/4). Žganje oksidacijsko. Dl. $9,9 \mathrm{~cm}, \mathrm{nv}$. s. $4,6 \mathrm{~cm}, \mathrm{nv}$. db. $2,8 \mathrm{~cm}$.

53. $\mathrm{SE}_{3}$, sonda I/20I $4, \mathrm{kv}$. 3, zač. inv. št. 3/I. Kamnit odlomek brusa, finozrnati peščenjak. Ovalnega preseka, na eni strani stanjšanega. Dl. 8,o cm, nv. š. 4, O cm, nv. db. $2,6 \mathrm{~cm}$.
54. SE $4 / 2$, sonda I/20I 4, kv. I, zač. inv. št. $4 / 2 / 1$.

Transportno posodje, odlomek zatiča rimskodobne amfore, izdelane na lončarskem vretenu iz finozrnate lončarske mase (posamezni grobi vključki) (CEF). Gladka površina je bledo rjava (IOYR 6/4). Žganje oksidacijsko. Pr. d. 3,4 cm, nv. dl. $9,3 \mathrm{~cm}$, v. $5,6 \mathrm{~cm}, \mathrm{db}$. zatiča $4,0 \mathrm{~cm}$.

55. KS I, zač. inv. št. KS/I/I.

Transportno? posodje, odlomek ostenja/ rame rimskodobne posode, izdelane na lončarskem vretenu iz finozrnate lončarske mase (s pogostimi drobnimi in grobimi vključki) (BCEF). Gladka površina je bledo rjava (IoYR 7/4). Žganje oksidacijsko. Dl. 9,4 cm, š. $5,5 \mathrm{~cm}$.

56. KS 2, zač. inv. št. $\mathrm{KS} / 2 / \mathrm{I}$. Odlomek rimskodobnega stekla turkizne barve. Dl. 2,6 cm, š. I, $8 \mathrm{~cm}, \mathrm{db} .0,2 \mathrm{~cm}$.

57. Čiščenje profila PI, zač. inv. št. SVP/I. Kuhinjsko posodje, odlomek ustja z ostenjem rimskodobne posode, izdelane na lončarskem vretenu iz drobnozrnate lončarske mase (s pogostimi grobimi vključki) (BCF). Gladka površina je temno rjava (7.5YR 6/6). Žganje oksidacijsko. Dl. $3,2 \mathrm{~cm}, \breve{s} .1,7 \mathrm{~cm}$. 

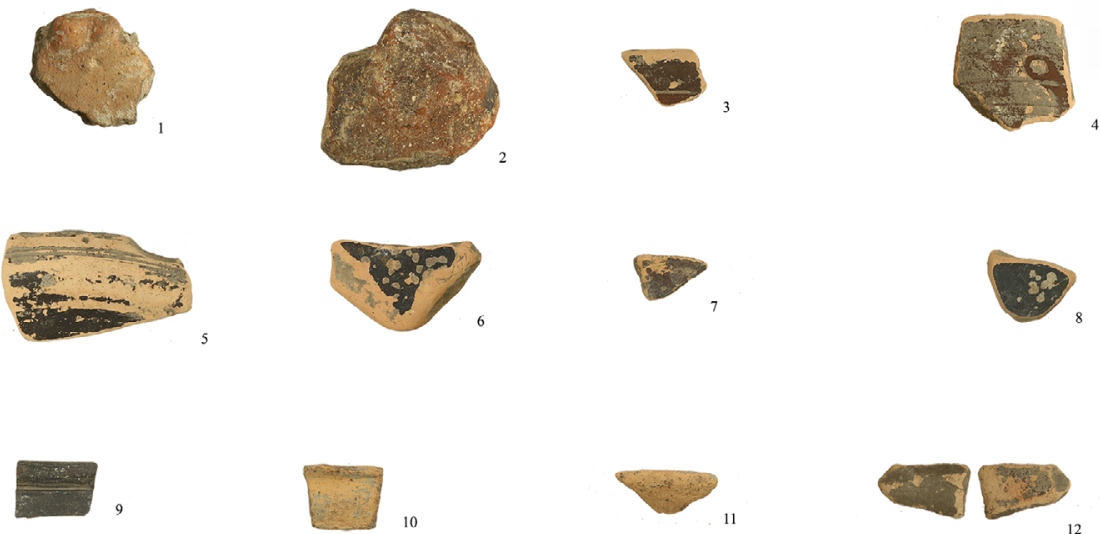

$\infty$
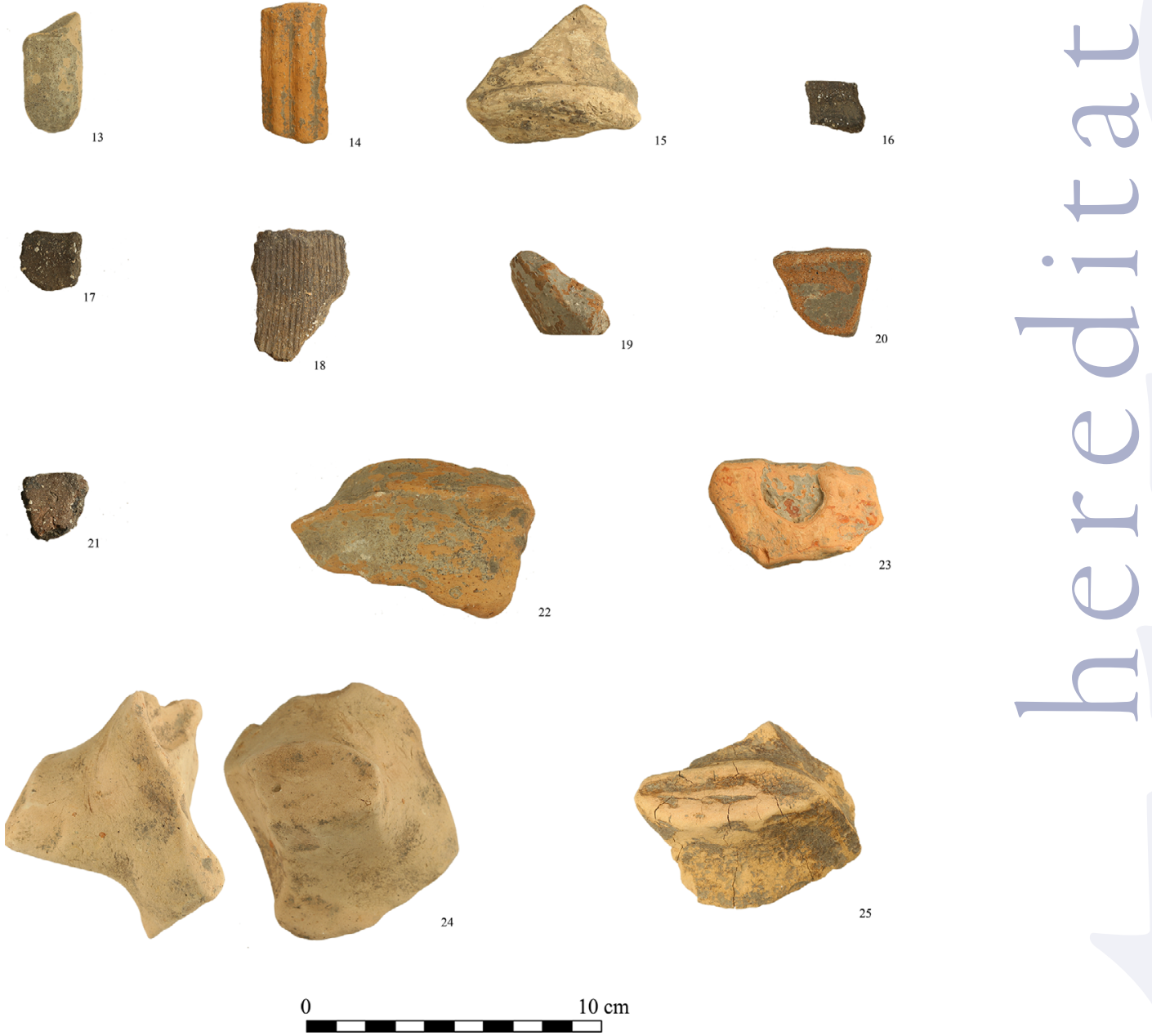

Slika 8. Kaštelir na Kortami, izbor, v fotografiji predstavljenega arheološkega gradiva (fotografije predmetov so označene s kataložnimi številkami) (foto: A. Ogorelec, arhiv IAD UP FHŠ). 

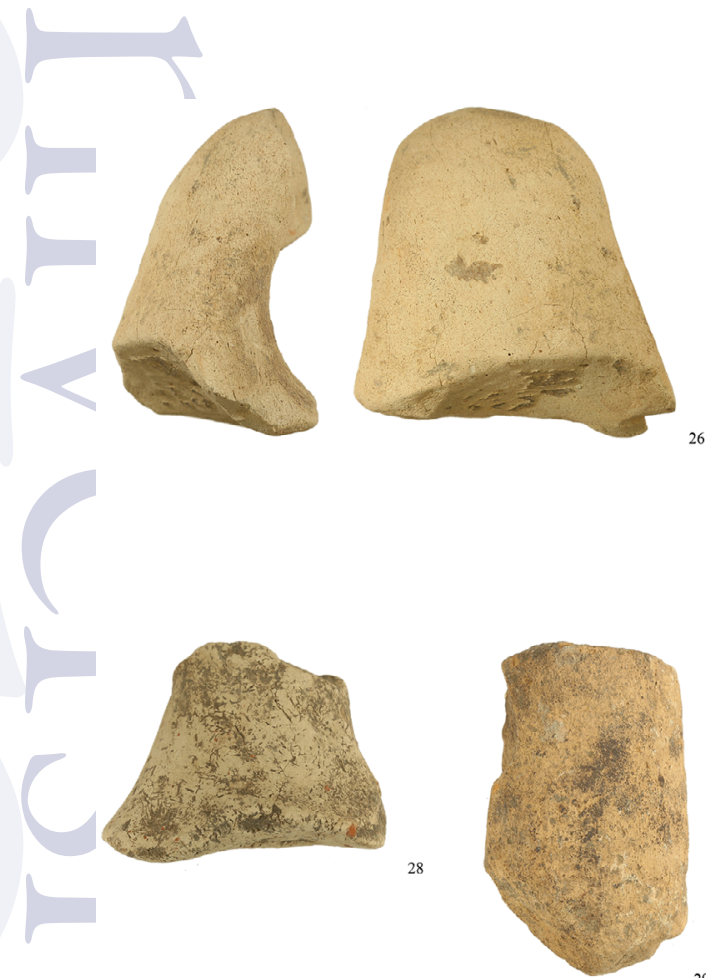

29
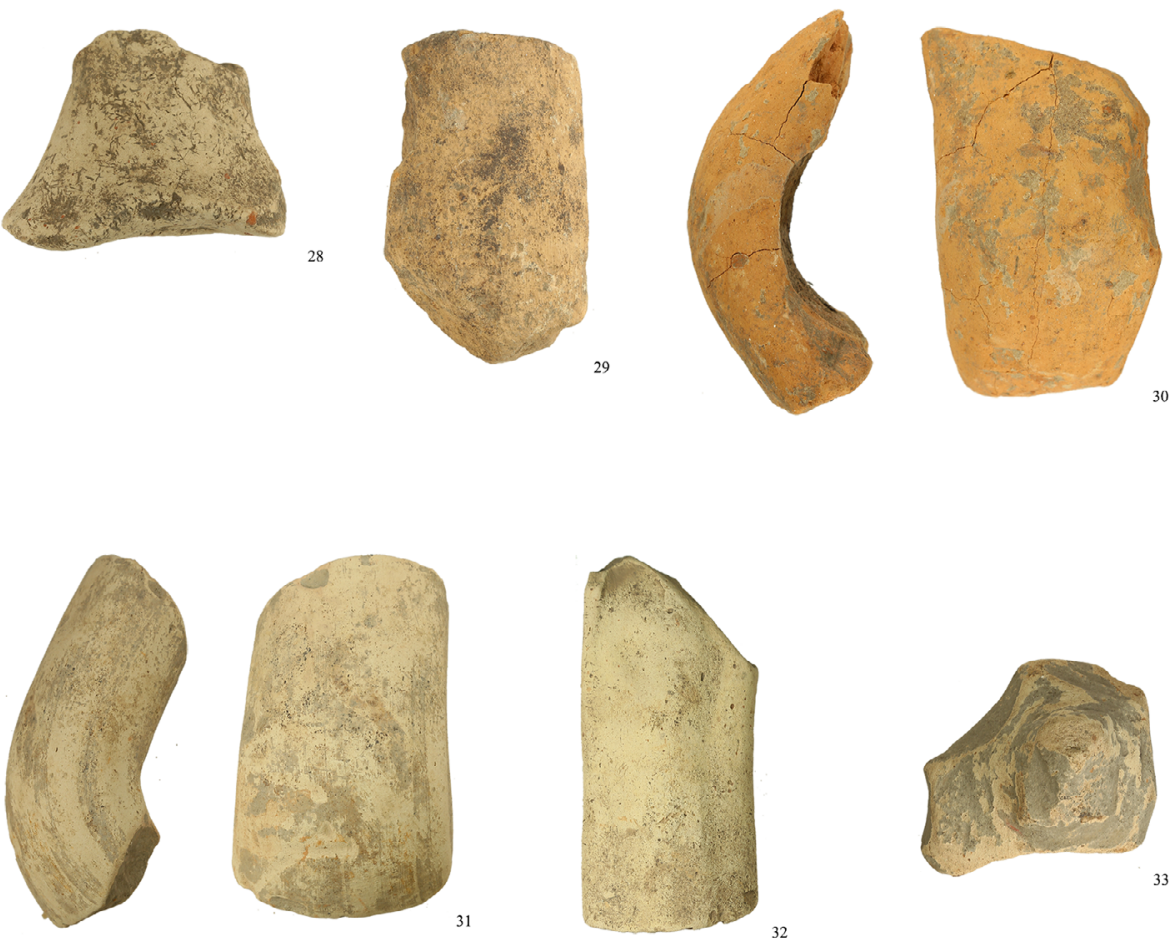

32

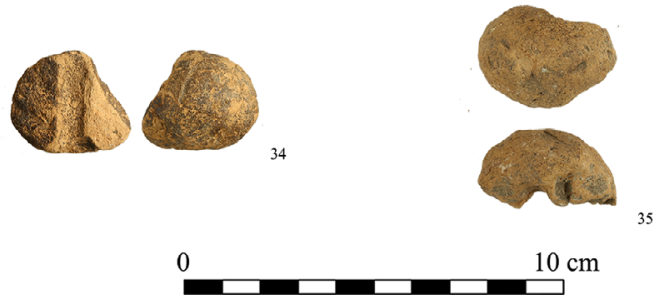

$\infty$

Slika 9. Kaštelir na Kortami, izbor, v fotografiji predstavljenega arheološkega gradiva (fotografije predmetov so označene s kataložnimi številkami) (foto: A. Ogorelec, arhiv IAD UP FHŠ). 

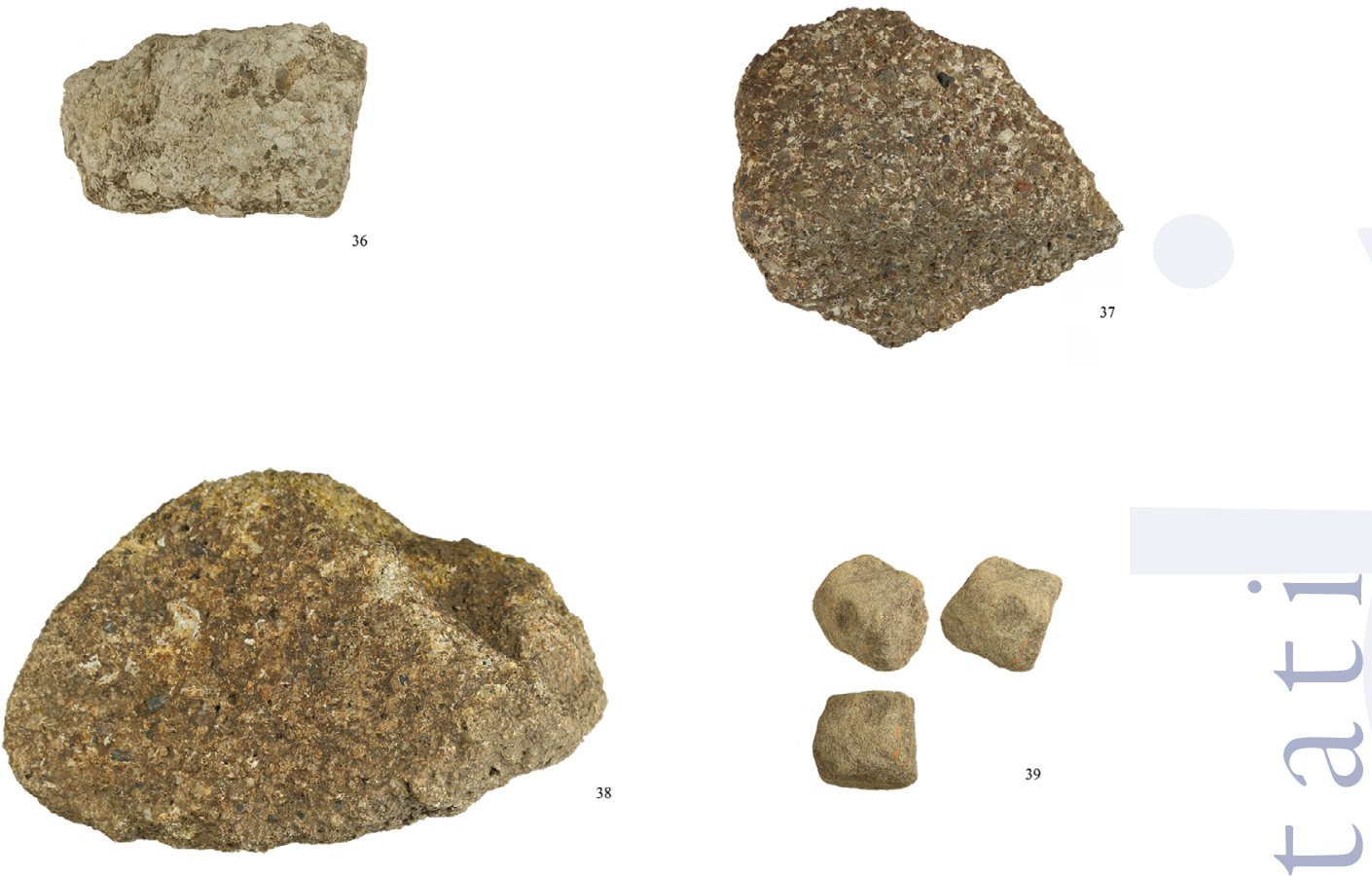

$\infty$

38
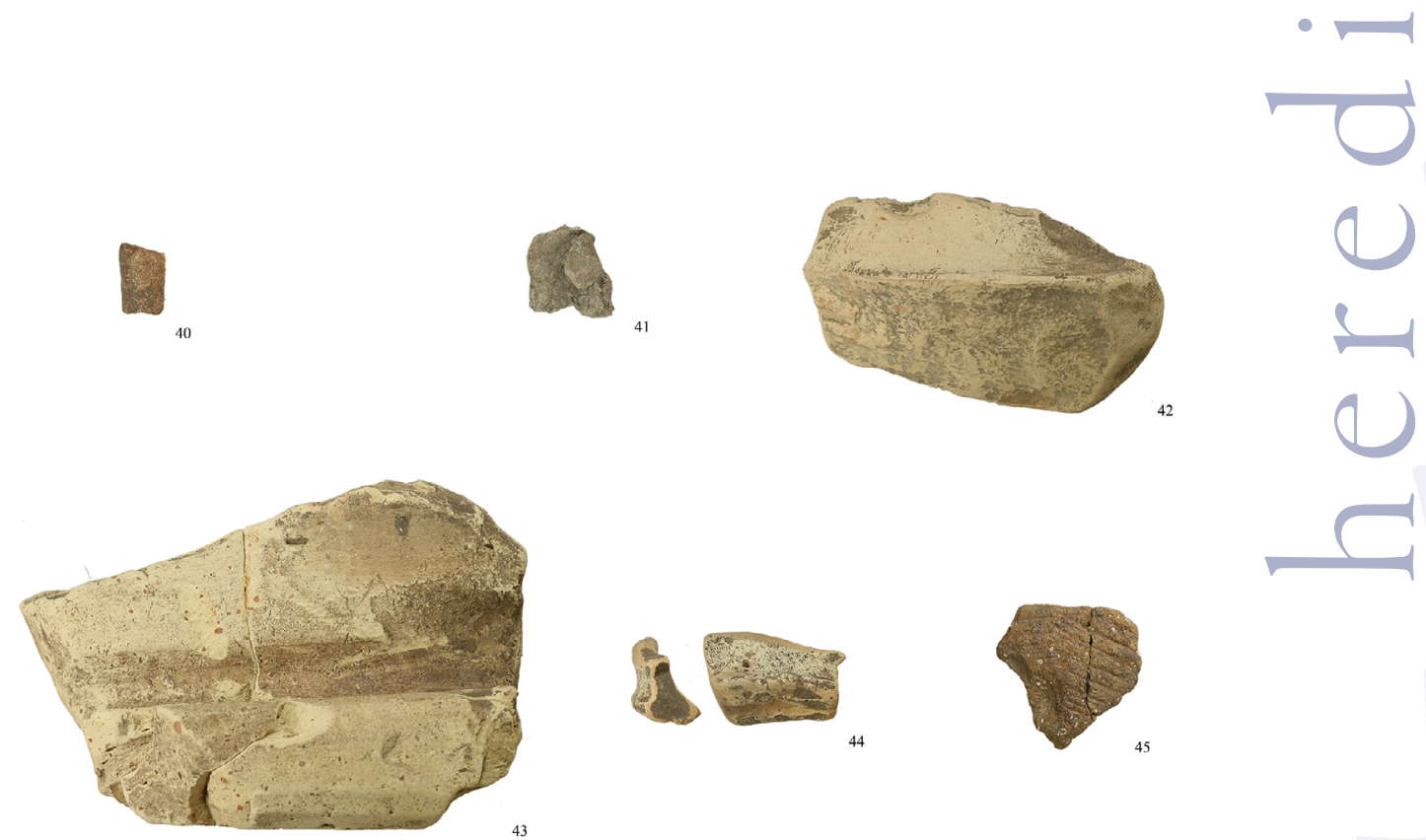

41
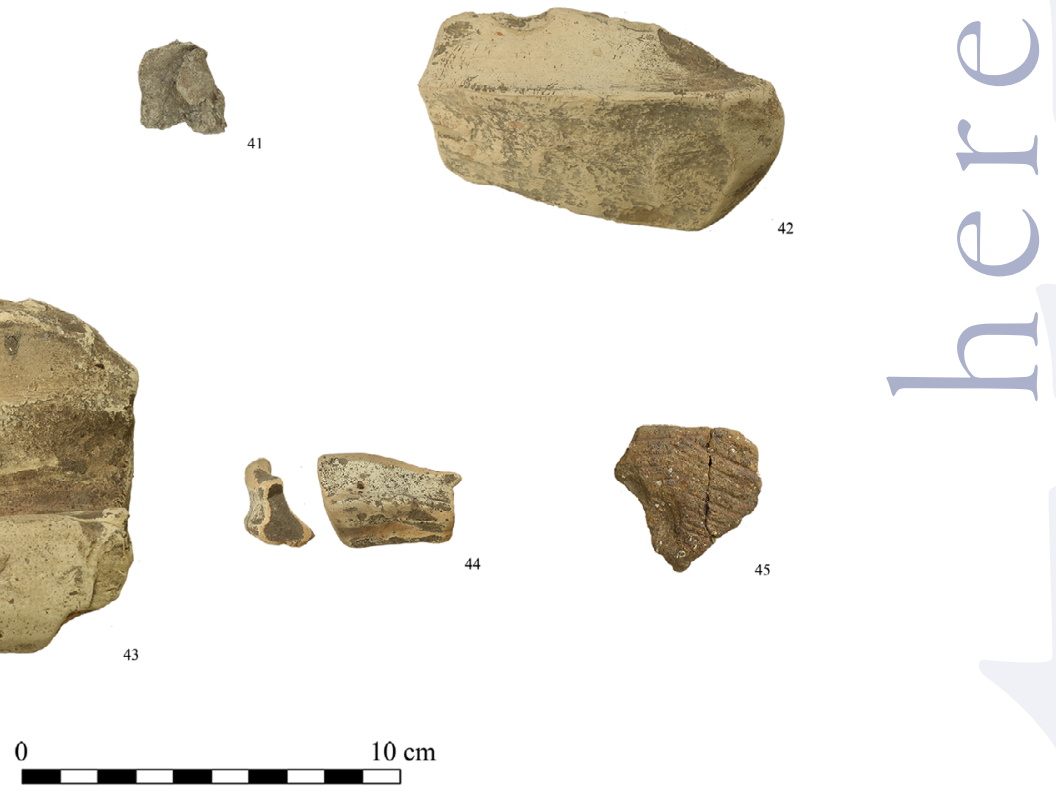

Slika ı. Kaštelir na Kortami, izbor, v fotografiji predstavljenega arheološkega gradiva (fotografije predmetov so označene s kataložnimi številkami) (foto: A. Ogorelec, arhiv IAD UP FHŠ). 


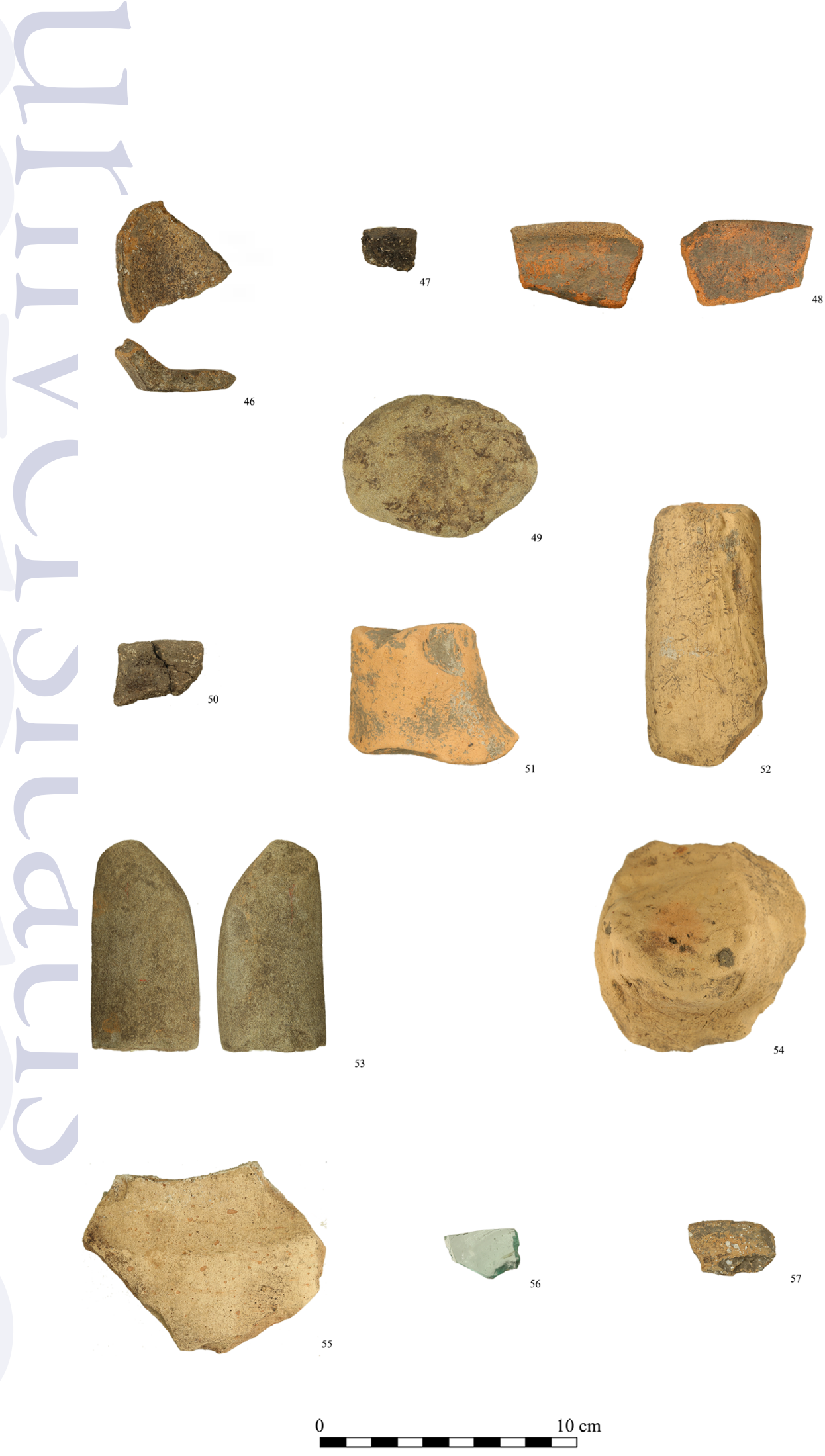

Slika II. Kaštelir na Kortami, izbor, v fotografiji predstavljenega arheološkega gradiva (fotografije predmetov so označene s kataložnimi številkami) (foto: A. Ogorelec, arhiv IAD UP FHŠ). 

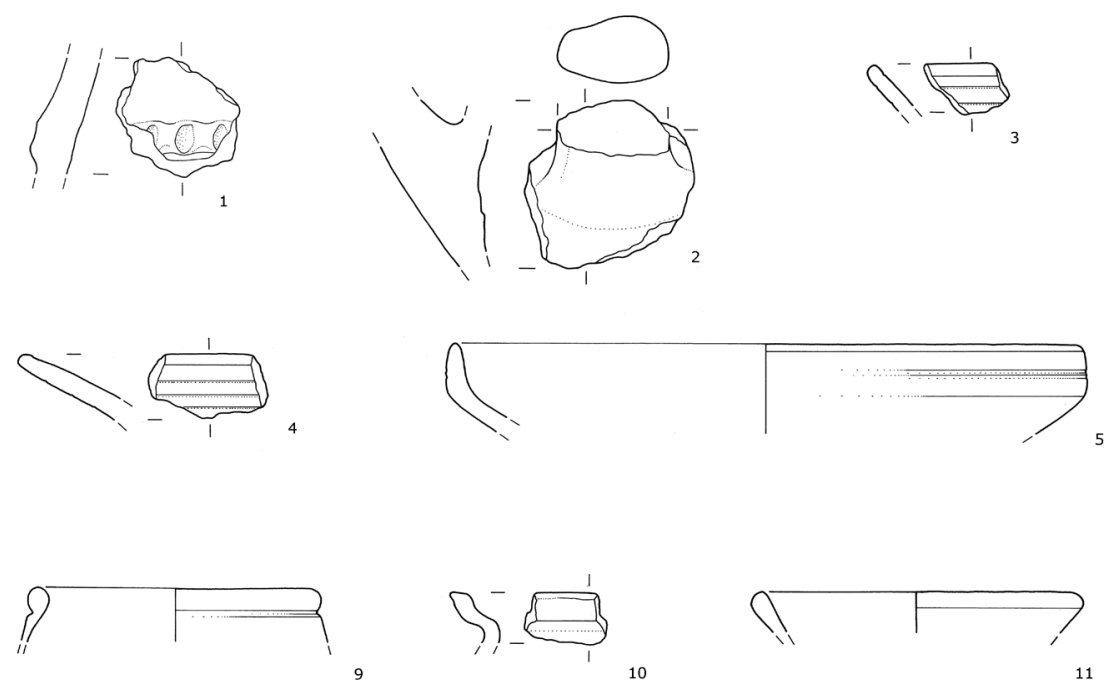

11

$\bullet$
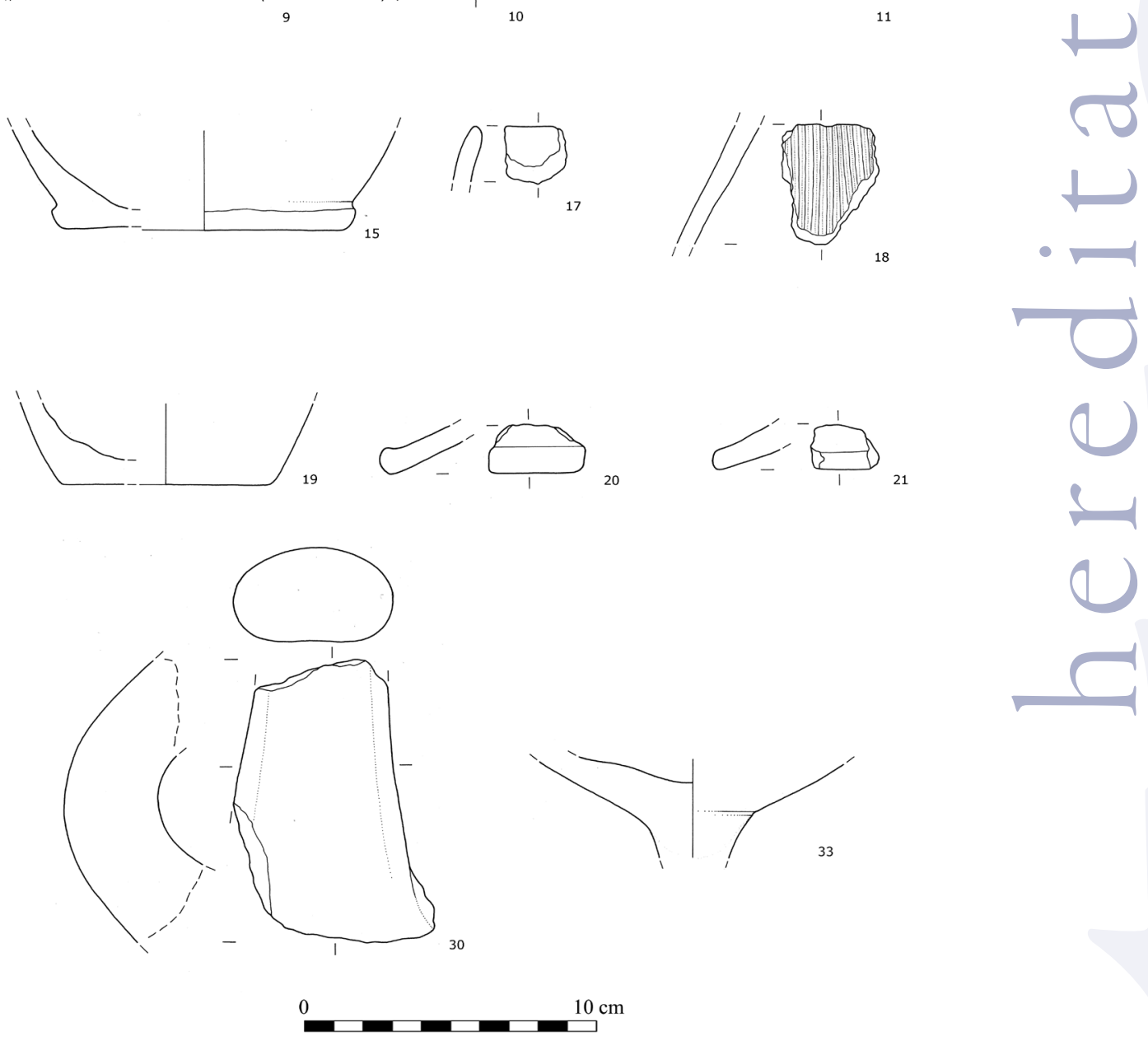

Slika I2. Kaštelir na Kortami, izbor, v risbi predstavljenega arheološkega gradiva (risbe so označene s kataložnimi številkami) (risba: Janja Tratnik Šumi). 

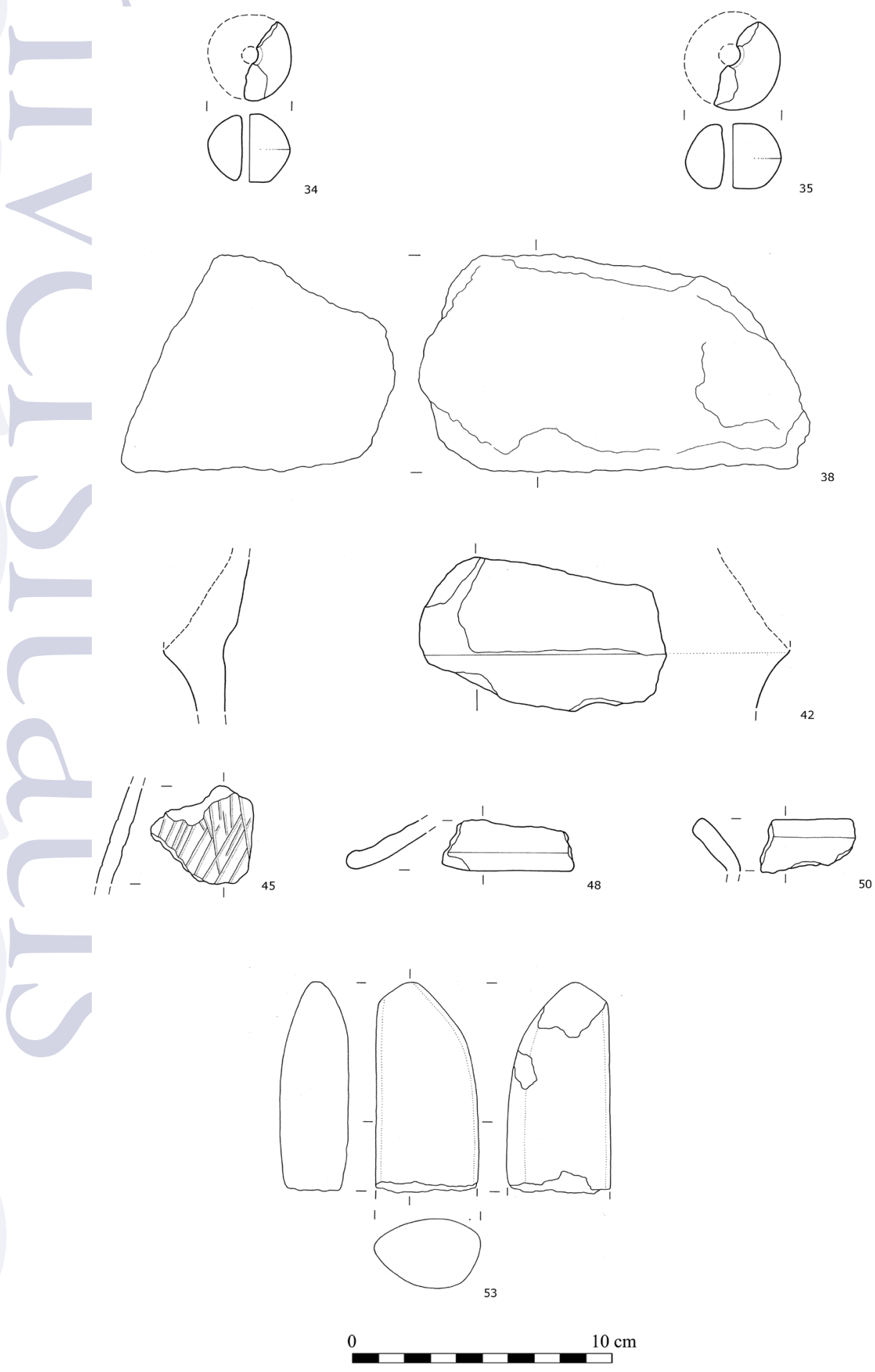

Slika i3. Kaštelir na Kortami, izbor, v risbi predstavljenega arheološkega gradiva (risbe so označene s kataložnimi številkami) (risba: Janja Tratnik Šumi). 

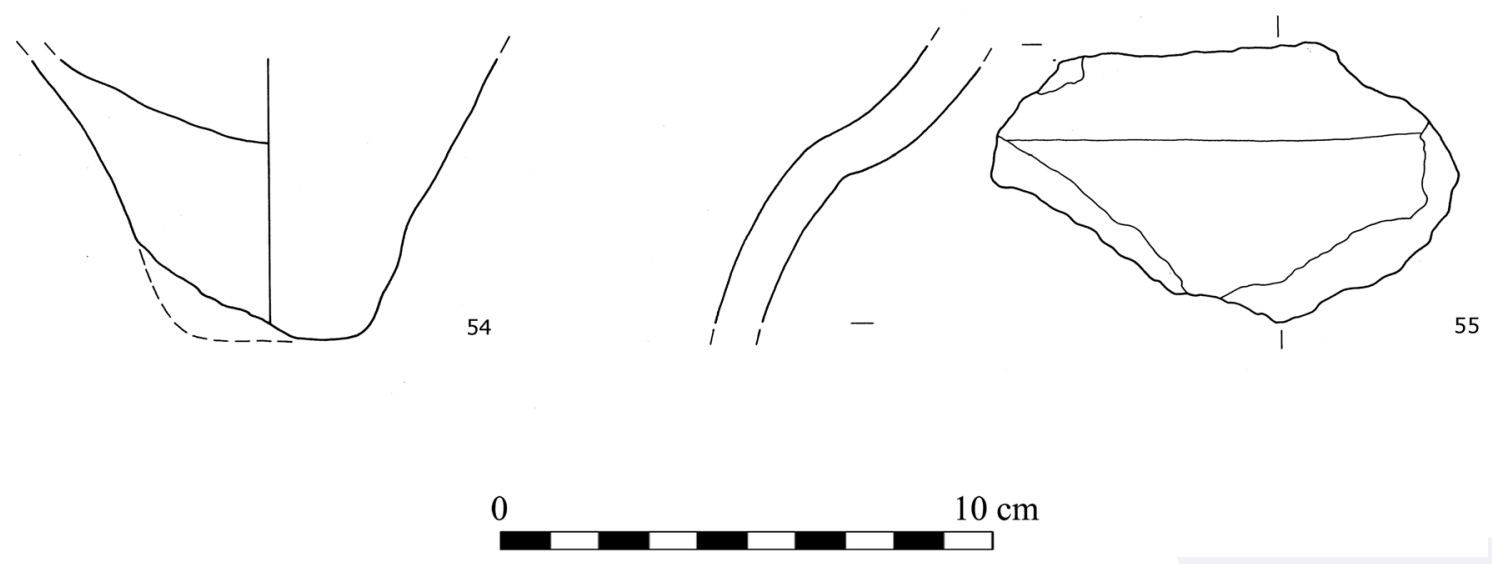

Slika i4. Kaštelir na Kortami, izbor, v risbi predstavljenega arheološkega gradiva (risbe so označene s kataložnimi številkami) (risba: Janja Tratnik Šumi).

\begin{tabular}{|c|c|c|c|c|c|c|c|c|c|}
\hline Podatki & & & & Gradivo & & & \multirow[b]{2}{*}{ školjke } & & 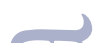 \\
\hline SE & keramika & kamni & gr. mat. & žel. predmeti & steklo & kosti & & & \\
\hline $\mathrm{SE}_{3}$ & 109 & I & 26 & & & 7 & 4 & & \\
\hline $\mathrm{SE}_{5}$ & I & & & & & & & & \\
\hline SE 8 & 8 & & & & & & I & - & \\
\hline $\mathrm{SE}_{9}$ & 23 & & & & & & 3 & & \\
\hline SE IO & 5 & & & & & 2 & $\mathrm{I} 2$ & & \\
\hline $\mathrm{SE}_{13}$ & 203 & I & I & & & 10 & 26 & & \\
\hline SE 16 & 35 & & I & & & 5 & 5 & & \\
\hline $\mathrm{SE}_{4 / 2}$ & 6 & & & & & I & 3 & & \\
\hline $\mathrm{SE}_{\mathrm{I} 4}$ & 1739 & 6 & 7 & & & 231 & 634 & & \\
\hline
\end{tabular}

Slika I5. Kaštelir na Kortami, tabelarični prikaz numerične zastopanost najdb glede na vrsto gradiva, po posameznih kontekstih (SE).

\section{Analiza in interpretacija arheološkega drobnega gradiva}

Arheološko drobno gradivo, odkrito v sondi I, sodi večinoma $\mathrm{v}$ rimsko obdobje, nekaj odlomkov je prazgodovinskih, odkrit pa je bil tudi novodoben železni predmet. Glede na zastopanost najdb po posameznih arheoloških kontekstih, ugotavljamo, da je bilo največ najdb odkritih $\mathrm{v}$ plasti SE I4, med največ odlomkov keramičnega gradiva $(\mathrm{N}=1739)$, posamezni obdelani kamni $(\mathrm{N}=6)$, odlomki gradbenega materiala $(\mathrm{N}=7)$, številni deli živalskih kosti $(\mathrm{N}=23 \mathrm{I})$ ter obilica školjk (N=634) (sl. I5, 16). Razmeroma številč̌no je bilo arheološko gradivo še v plasteh SE 13 in $\mathrm{SE}_{3}$, sicer pa so bile najdbe $\mathrm{v}$ evidentiranih arheoloških plasteh in ostalinah razmeroma maloštevilne (sl. I5, 16).

Prazgodovinske najdbe so bile v sondi I razmeroma redke. Keramika podobnih oblik, okrasa in tehnološke izdelave, kot sta odlomka posodja iz plasti SE 14: GI, G22, je bila najdena tudi v preteklih arheoloških raziskavah na Kašte- 


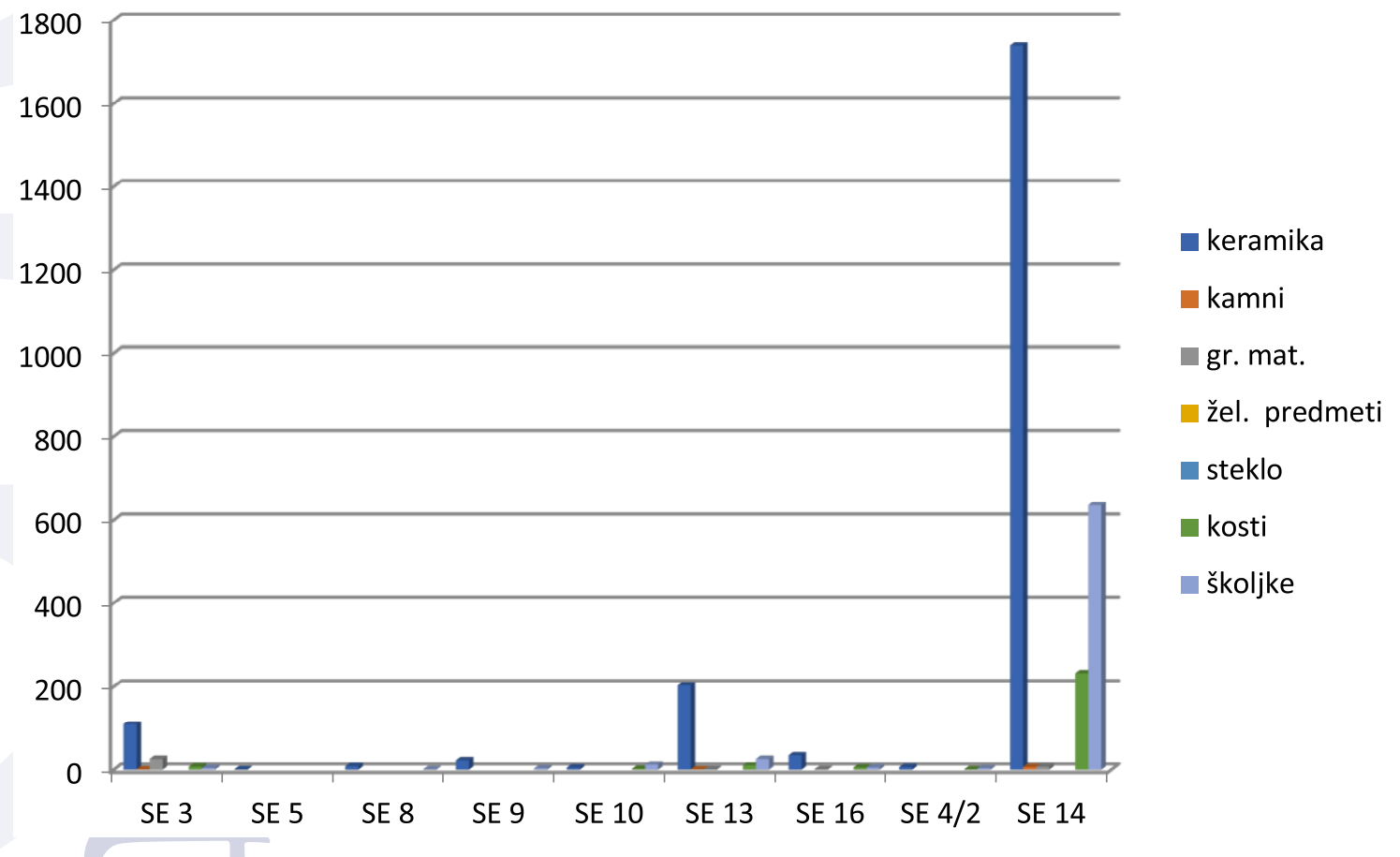

Slika ı6. Kaštelir na Kortami, grafični prikaz zastopanosti arheoloških najdb, po posameznih kontekstih (SE).

lirju ${ }^{16}$ kakor tudi npr. na Serminu ${ }^{17}$ in jo lahko pripišemo bronastodobni poselitvi obravnavanega območja.

Med rimskodobnimi najdbami so bili $\mathrm{v}$ sondi I odkriti razmeroma številni odlomki izdelkov iz keramike, med njimi odlomki finega namiznega posodja, namiznega posodja, kuhinjskega posodja in transportnega posodja, odlomki kamnitih predmetov, med njimi npr. odlomki žrmelj in brusa, ter fragmenti svinca.

\section{Fino namizno posodje}

Keramika s črnim premazom je v sondi $\mathrm{I} / 20 \mathrm{I} 4$ zastopana s 7 odlomki (G3, G4, G5, G6, G7, G8, G9), odlomki ustij in ostenji, npr. v plasti SE i4. Tovrstna keramika je razprostranjena po celotni obali (npr. Sermin, Fornače, Piran, Pulj, Pomljan, Simonov zaliv idr.) ter je v uporabi od 4. (zahodno Sredozemlje in Italija) do začetka

I6 Sakara Sučevič, Prazgodovinska keramika med Miljskim zalivom in porečjem Mirne, npr. G558, G582, G583, G600, G601, idr.

17 Sakara Sučevič, Prazgodovinska keramika med Miljskim zalivom in porečjem Mirne, npr. Gi87.
I. stoletja pr. n. št. najstarejši primerki v Istri so poznani iz Nezakcija (sr. 3, zač 2. stoletja pr. n. št.). Tovrstno keramiko so izdelovale delavnice v Etruriji, Padaski nižini ter na severozahodni jadranski obali, medtem ko so primerki slabše kvalitete izdelovale delavnice v Riminiju, morda celo v Akvileji in njeni okolici (severnojadranske delavnice).

V prvi polovici I. stol. pr. n. št. se v severni Italiji razvije posebna proizvodnja t. im. srednjepadanska keramika s črnim premazom, ki je bila razširjena po vsej Padski nižini in je dosegla tudi Štalensko goro (tam je poimenovana porozni fabrikat) ${ }^{18}$. Skleda (primerek Gs) ima podobne analogije tudi na Fornačah ${ }^{19}$ in $\mathrm{Okri}^{20}$.

\footnotetext{
I8 Marko Stokin, "Naselbinski ostanki iz ı. st. pr. n. št. v Fornačah pri Piranu," Arheološki vestnik 43 (1992): 84; Jana Horvat in Alma Bavdek, Okra, Vrata med Sredozemljem in Srednjo Evropo, Opera Instituti Archaeologici Sloveniae i7 (Ljubljana: ZRC SAZU, 2009), 57.

I9 Stokin, "Naselbinski ostanki iz i. st. pr. n. št.v Fornačah pri Piranu," t. $2 / \mathrm{I}, 3$.

20 Jana Horvat in Alma Bavdek, Okra, Vrata med Sredozemljem in Srednjo Evropo, Opera Instituti Archaeologici Sloveniae i7 ( Ljubljana: ZRCSAZU, 2009), t. 40/1, masa ČP3.
} 
Keramika s črnim premazom je bila najdena tudi na Serminu ${ }^{21}$. Izdelke poroznega fabrikata/srednjepadanske keramike so izdelovali v obdobju od konca 2. stoletja pr. n. št. do začetka I. stoletja n.št. ${ }^{22}$.

\section{Namizno posodje}

Namizno posodje (primerki Gıo, GII, GI2, GI3, Gi4, Gi5, G44) iz različnih stratigrafskih enot (SE I 4, SEI3) je verjetno severno jadranske proizvodnje in je pogosto na najdiščih na Slovenski obali, npr. Sermin ${ }^{23}$ in slovenskega zaledja, predvsem ob prometnicah, npr. na Okri ${ }^{24}$.

\section{Kuhinjsko posodje}

Kuhinjska keramika (primerki Gi7, Gi8, Gi9, $\mathrm{G}_{20}$, G21, G45, G46, G47, G48, G50, G57, G23, $\mathrm{G}_{25}, \mathrm{G}_{55}$ ) je bila odkrita na primer v plasteh $S E$ ${ }_{14}$, SE $\mathrm{I}_{3}$ in $\mathrm{SE}_{3}$ in je časovno težje opredeljiva, saj je bila po večini izdelek lokalnih delavnic. Podoben okras glavničenja na kuhinjskih loncih kot na primerku Gi8 se pojavlja tudi na Fornačah ${ }^{25}$, prav tako je iz istega najdišča podoben lonec kot naš primerek $\mathrm{G}_{5} \mathrm{O}^{26}$.

\section{Transportno posodje}

Velik del keramičnih odlomkov pripada transportnemu posodju, ki je bilo odkrito na primer v plasteh SE 14, SE 16 in $\mathrm{SE}_{3}$ (primerki G22, G23, $\mathrm{G}_{24}, \mathrm{G}_{26} 6, \mathrm{G}_{27}, \mathrm{G}_{28}, \mathrm{G}_{29}, \mathrm{G}_{31}, \mathrm{G}_{32}, \mathrm{G}_{33}, \mathrm{G}_{42}$, G51, G52, G54).

Amfore tipa Lamboglia 2 in kasneje Dressel 6A sta značilni obliki transportnega posodja $v$ zgodni antiki. Lamboglia 2 se je pojavljala $\mathrm{v}$ času od konca 2. stoletja do sredina $\mathrm{I}$. stoletja pr. n. št. na jadranski obali in je bila namen-

\footnotetext{
2 I Ana Plestenjak, ur., Sermin, Arheološke raziskave v letu 2010, (Ljubljana: Arhej d.o.o., 2012), 93, npr. G92.

22 Plestenjak, Sermin, Arbeološke raziskave v letu 20I0,93.

23 Plestenjak, Sermin, Arheoloske raziskave v letu 2010, 94

24 Jana Horvat in Alma Bavdek, Okra, Vrata med Sredozemljem in Srednjo Evropo, Opera Instituti Archaeologici Sloveniae 17 ( Ljubljana: ZRCSAZU, 2009), 74 .

25 Stokin, "Naselbinski ostanki iz i. st. pr. n. št. v Fornačah pri Piranu," t. $4 / 3$.

26 Stokin, "Naselbinski ostanki iz i. st. pr. n. št. v Fornačah pri Piranu," t. $4 / 2$.
}

jena transportu vina. Istočasno (konec 2. stoletja pr. n. št. do srednjeavgustejskega obdobja) se na zahodnojadranski obali razvije ovaloidna oblika Bransidi, namenjena transportu olja. Kasneje v zadnji tretjini I. stoletja pr. n. št. v delavnicah severozahodnega in vzhodnega Jadrana začnejo izdelovati robustnješo obliko amfor, ki nadomestijo obliko Lambogia 2, Dressel 6A. Obe obliki amfor sta hruškaste oblike z okroglimi ročaji in visokim zatičem, medtem ko je oblika Brindisi ovalne oblike s kratkim zatičem ${ }^{27}$.

$\mathrm{Na}$ podlagi analogij smo amforam tega tipa pripisali tudi odlomke ostenij $\mathrm{G}_{22}$ in $\mathrm{G}_{42}$ ter večino ročajev transprotnega posodja ovalnega preseka. Dno amfore $\mathrm{z}$ delno ohranjenim zatičem $\mathrm{G}_{33}$ in ročaj $\mathrm{G}_{30}$ bi lahko bili del amfore Brindisi. Zatič $\mathrm{G}_{33}$ je sorazmeroma kratek in morda pripada amfori tipa Dressel 2-6. Med transportno posodje smemo prišteti tudi odlomke, ki po masi in obliki niso značilni za amfore, verjetno pa so odlomki večjih shrambenih posod (primerki G23, G25, G55).

\section{Ostalo}

V sondi I so bili najdeni tudi trije odlomki ročnih mlinov - žrmlje (primerki G36, G37, G38), iz različnih kamenin, vendar le en $\left(\mathrm{G}_{3} 8\right)$ opredeljen kot zgornji kamen - tekač. Odkrita sta bila tudi odlomek kamnitega brusa (G53) v SE 3 ter odlomek kamnite kocke (G39) v SE I4.

Fragmenti svinca $\left(\mathrm{G}_{4} \mathrm{I}\right)$ so bili najdeni tudi na Serminu (k. št. 88, ı80, 500), kjer so bili interpretirani kot uteži za ribiške mreže ${ }^{28}$. Tudi keramični predmeti, podobni sicer predilnim vretencem, bi se lahko uporabljali pri ribolovu kot uteži, morda plovci.

Podobo so opredeljeni predmeti najdeni na Fornačah pri Piranu ${ }^{29}$. Kot pripomočke za ribolov bi lahko umestili tudi kamnit ovalen predmet, morda kamnito utež (G49).

\footnotetext{
27 Verena Vidrih Perko, Amfore v Sloveniji, Annales, Ser. hist. sociol. io, št. 2 (22), (2000), 42 I-456; Silvia Cipriano in Francesca Ferrarini, Le amfore romane di Opitergium, Cornuda (Oderzo: Lions club di Oderzo, 200I), 53 .

28 Plestenjak, Sermin, 34.

29 Stokin, "Naselbinski ostanki iz i. st. pr. n. št. v Fornačah pri Piranu," t. $5: 6-8$.
} 
Interpretacija arheoloških plasti in arheoloških ostalin v sondi I

Stratifikacija plasti in struktur se je na raziskanem območju najdišča izkazala za enostavno. Vse evidentirane ostaline so bolj ali manj vezana na procese in dejavnosti, ki so se odvijale v rimskem obdobju. Najstarejšo evidentirano plast na tem delu najdišča predstavlja SE I4 ( $f a z a I)$, kulturna plast, ki je ležala neposredno na geološki osnovi SE is. Odkrita je bila na celotni raziskani površini sonde, predvidevamo pa tudi, da se nahaja še izven izkopnega polja. Nanjo odložena ruševinska plast SE 16, ki je bila dokumentirana v zahodnem delu sonde, in je po strukturi močno podobna SE I2, zaradi česar sklepamo, da sta obe evidentirani plasti posledica iste aktivnosti in sta sočasni ( faza 2). Konstrukcija kamnite strukture I se je začela po odložitvi SE i6 in SE I2. Najprej je bil izgrajen notranji del, sestavljen iz manjših kamnov in lomljencev (SE 4), kateri je bil nato zamejen $\mathrm{z}$ vencem iz večjih kamnitih plošč SE 2. Gradnja notranjih elementov kamnite strukture pripada $f a z i$, gradnja obodnega venca pa fazi 4 . Sledilo je formiranje plasti SE I3, ki se je odložila le v skrajnem severnem vogalu sonde ob kamniti strukturi in nato nanjo tudi plast SE 9. Obe vključujeta rimskodobne najdbe, v $S E$ i3 pa so bili odkriti tudi posamezni odlomki prazgodovinske lončenine. SE 9 je prekrila plast $S_{3}$, ki se je podobno kot SE 9 in SE 13 odložila le ob obstoječi kamniti strukturi I. V njej sta bila poleg razmeroma številnega rimskodobnega keramičnega gradiva odkrita tudi dva odlomka, ki bi ju morda lahko pripisali srednjeveškemu obdobju. $S$ pravi, da je nastala bistveno kasneje od predhodnih SE 9 in SE I3. Vse skupaj je prekrila travna ruša SE I.

Čiščenje kamnitih struktur $I$ in 2 na parc. št. 1504 k.o. Dvori nad Izolo

Ob testnih sondiranjih se je izvajalo tudi čiščenje in dokumentiranje kamnitih struktur $\mathrm{I}$ in 2 na parc. št. 1504 k.o. Dvori nad Izolo (sl. 4). Čiščenje kamnitih struktur je potekalo na način, da se je odstranilo podrastje in suho listje, arhitekturni ostanki in zemljeni depoziti pa so se ohranjali na mestu odkritja. Strukturi sta se očistili do te mere, da je bilo možno geodetsko merjenje in fotografska dokumentacija območja.

\section{Kamnita struktura I}

- parc. št. Iso4 k.o. Dvori nad Izolo

Kamnita struktura I, ki je sestavni del našega preučevanja, je ležala ob vzhodnem robu parcelne meje, oblikovana nepravilno podolgovato v smeri vzhod - zahod. Njen južni rob je bil bolj strm kot severni, proti zahodu se je spuščala bolj blago. Njena višina je na najvišjem delu presegala I m. Pred našim prihodom je bila precej zaraščena s travo in nizko podrastjo (bršljan, trnje idr.), na njenem vzhodnem delu pa se je nahajala tudi višja zarast $v$ obliki hrastov, ki ob procesu dokumentiranja ni bila odstranjena. Na vrhu strukture so bili kamni precej razrahljani in poraščeni z mahom, prostor med njimi pa prazen oziroma zapolnjen $s$ humusom, preperelo lesno maso in suhim listjem. Na njenem zahodnem in severnem delu je kamnito strukturo v večji meri zaraščala trava (sl. 17a, b).

Po postopku čiščenja je bilo dokumentirano stanje, kot sledi. Kamnita struktura I (groblja) je bila velika $15,54 \times 7,6 \mathrm{~m}$. Sestavljena je bila iz nevezanih lomljencev in kamnov peščenjaka ter fliša. Podrobno je bil dokumentiran le njen vidni del, sta pa bili na območju v povezavi z njo dokumentirani kamnito vsaj še dve manjši groblji kamenja, ki kažeta na to, da se struktura nadaljuje tudi pod današnjo travnato ruši (( $\mathrm{SE} 2$ in $\mathrm{SE}$ $4 \mathrm{v}$ testni sondi I ). Zunanje mere vseh zaznanih elementov kamnite strukture znašajo I8,9 x I2,7 $\mathrm{m}$. Kamnita struktura najverjetneje ni nastala ob enkratnem procesu, ampak je povsem možno, da sta obe manjši groblji, SV od dokumentirane, nastali kot posledica primarne destrukcije kamnite strukture I. Na celotni površini kamnite strukture ni bilo najti takorekoč nikakršnih arheoloških najdb, izjemo je predstavljal primerek ostenja rimskodobne transportne posode Gss.

\section{Kamnita struktura 2}

- parc. śt. I504/k.o. Dvori nad Izolo

Kamnita struktura 2 je ležala severno od strukture $\mathrm{I}$ in od testne sonde $\mathrm{I}$, ob parcelni meji $s$ 


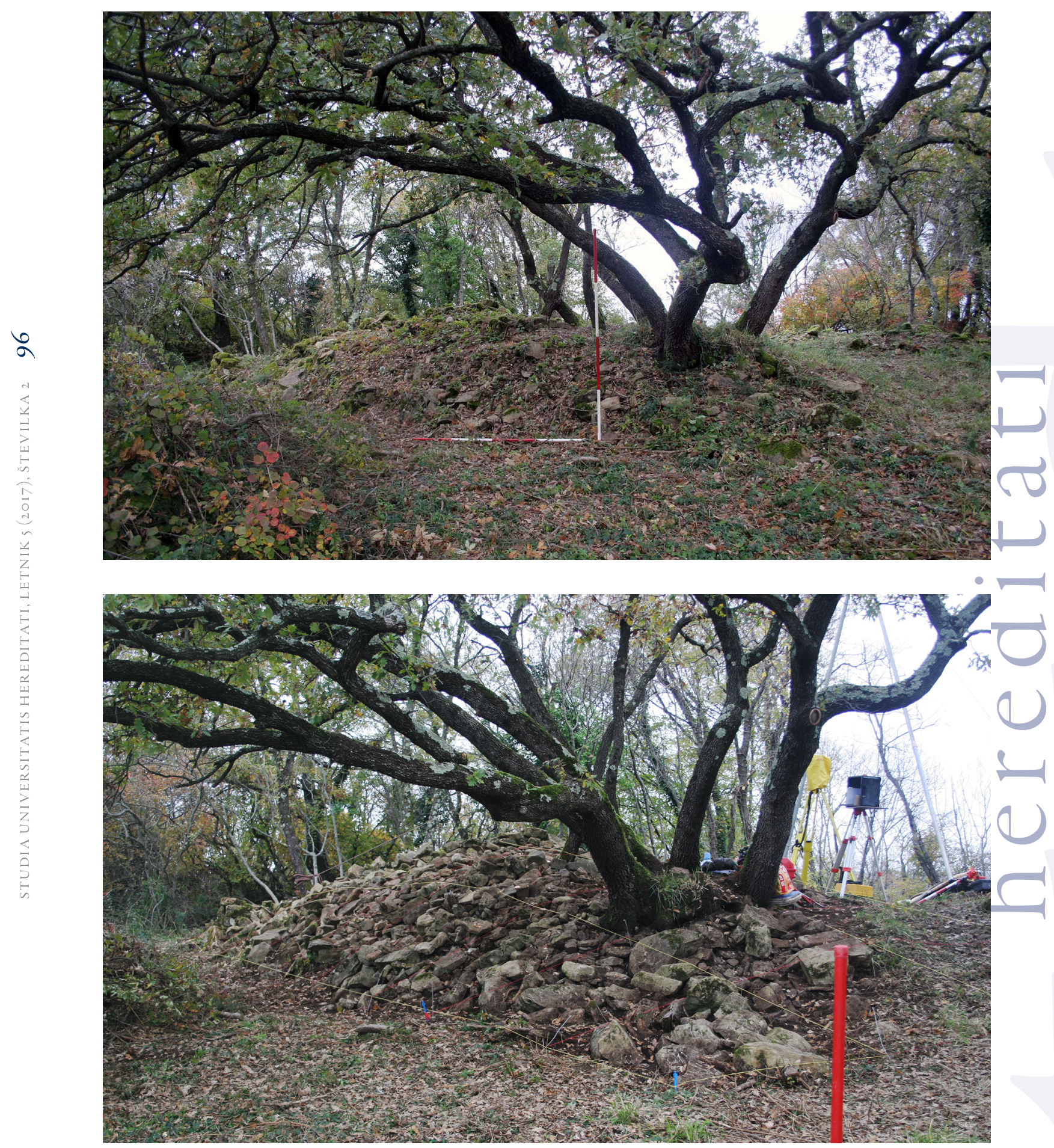

Slika 17. Kaštelir na Kortami, kamnita struktura I, pred čiščenjem (a) in po čiščenju (b) (foto: A. Ogorelec, arhiv IAD UP FHŠ). 

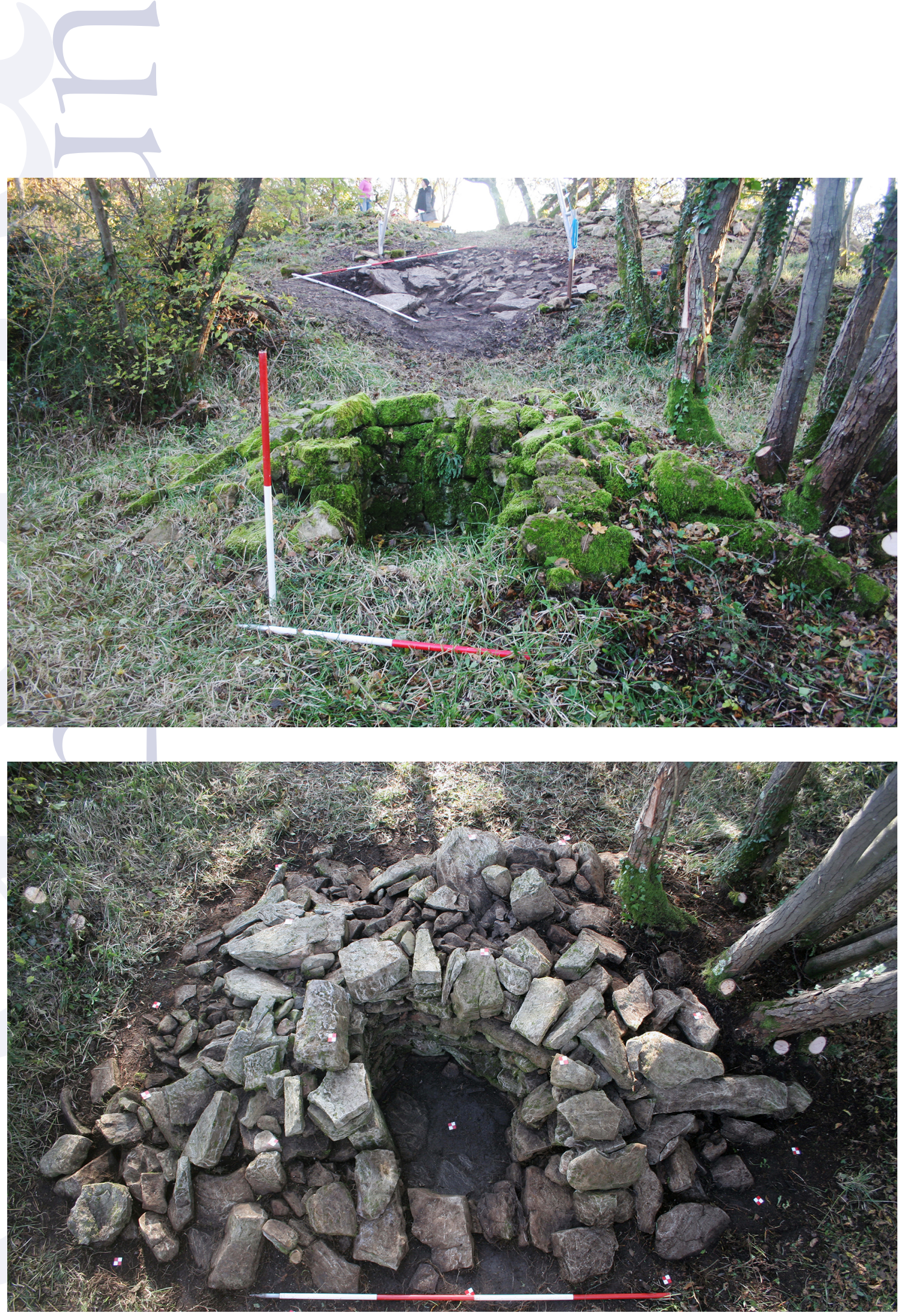

Slika 18. Kaštelir na Kortami, kamnita struktura 2, pred čiščenjem (a) in po čiščenju (b) (foto: A. Ogorelec, arhiv IAD UP FHŠ). 
parcelo parc. št. I50s k.o. Dvori nad Izolo. Pred čiščenjem je bila povsem zarasla s travo in nižjim rastjem ter prekrita $\mathrm{z}$ mahom. Struktura je bila na zahodnem delu precej poškodovana $\mathrm{z}$ višjim rastjem (sl. ı $8 \mathrm{a}, \mathrm{b})$.

Po postopku čiščenja se je pokazalo, da je kamnita struktura 2 velika 4,5 × 2,9 $\mathrm{m}$ in sestavljena iz nevezanih lomljencev ter kamnov peščenjaka, ki so $\mathrm{v}$ glavnem ležali $\mathrm{v}$ njeni ruševina. Nekateri deli strukture so verjetno obdržali še originalno gradnjo iz suhozida kot npr. notranji prostor in jugozahodni vogal strukture zidan na fronto. Struktura je imela oblikovan tudi notranji prostor, ki je na zahodni strani zalomljen in oblikovan v neke vrste vhod oziroma odprtino. Dokumentirana velikost je bila o,9 x o,63 $\mathrm{m}$. Začetek vhoda je bil zamejen z večjim, pokonci stoječim blokom kamenja, na nasprotni strani pa z zamikom ovalno-polkrožne stene. V osrednjem delu prostora je bila evidentirana humusna plast zelo temno sivega humusa s drobci oglja, odlomki rimskodobne keramike in odlomkom stekla. V severozahodnem delu prostora pa je bila odkrita zaplata temno sive gline, pod humusom pa so se na jugovzhodnem delu nahajale še kamnite plošče, ki verjetno predstavljajo tlakovanje notranjega prostora.

Kamnita struktura 2 je zanimiva predvsem zato, ker se so po njenem čiščenju pokazali posamezni elementi, ki izkazujejo njeno namensko gradnjo. Vidne so bili deli originalne gradnje objekta, kot npr. polkrožno grajen notranji del, vogalni kamni zunanjega zidu itd. Najdb je bilo v njej malo, le odlomek antičnega stekla v sekundarni legi, ki pa ne zadošča potrditev domneve, da je kamnita struktura 2, ravno tako kot kamnita srtruktura I, nastala rimskem obdobju.

\section{Sklep}

Arheološko testno sondiranje na Kaštelirju nad Kortami pri Izoli je bilo načrtovano in izvedeno z namenom, da bi se evidentirala stratifikacija arheoloških ostalin na tistemu delu najdišča, kjer se v preteklosti ni intenzivno kmetovalo. $S$ pomočjo relativnih stratigrafskih odnosov pa smo želeli natančneje definirati čas nastanka kamnitih struktur na vrhu platoja.

Testna sondiranja so ponudila zelo zanimive in hkrati presenetljive rezultate. Presenetljivi so predvsem zaradi tega, ker smo z izborom lokacije sonde predvidevali, da bomo odkrili sosledje ohranjenih prazgodovinskih plasti in ostalin, kot je bilo to zaznano pri raziskavah na južnem delu platoja v letih med 2008 in 2010 . Izkazalo pa se je, da so na tem delu najdišča ohranjene samo sledi antične poselitve, redke prazgodovinske najdbe pa so se nahajale le $\mathrm{v}$ sekundarnem kontekstu rimskodobnih ruševinskih in kulturnih plasti. Posamezni odlomki prazgodovinske keramike, ki so bili odkriti v sekundarnem kontekstu, lahko kažejo bodisi na uporabo prostora $\mathrm{v}$ prazgodovinskem času ali pa na dejstvo, da so rimskodobne aktivnosti prazgodovinske ostaline povsem uničile. Ravno tako presenetljivo pa je tudi dejstvo, da na prostoru raziskav nismo zaznali nikakršnih posegov v geološko osnovo.

Testna sondiranja ter čiščenje in dokumentiranje kamnite strukture so pokazali, da je bila le-ta grajena oziroma zamejena namensko z večjimi kamnitimi ploščami po obodu. Najprej je bila izgrajena notranjost, kasneje pa ji je bil dodan zunanji venec, sestavljen iz velikih kamnitih plošč. Na ta način je bila grajena kamnita struktura, raziskana v letu 2009. Začetek njenega nastajanja je sicer težko natančneje precizirati, vendar pa stratigrafska situacija in sosledje ruševinskih plasti $\mathrm{v}$ testni sondi ponujata dve možni interpretaciji. Najverjetneje je velika kamnita struktura na parc. št. I504 k.o. Dvori nad Izolo začela nastajati v rimskem času. $\mathrm{Ne}$ sicer v njegovem zgodnjem odseku, saj se pod samo kamnito strukturo in pa ob njej nahajajo rimska ruševinska in rimska kulturna plast, katerima lahko pripišemo zgodnejši nastanek, ampak v kasnejših obdobjih antike. Druga možna interpretacija pa bi bila, da so kamnite strukture dejansko nastale kasneje (npr. v srednjem veku) in so pri tem povsem uničile rimske ostaline. Slednja interpretacija je sicer manj verjetna, ker med drobnim arheološkim gradivom, najdb kasnejših časovnih obdobij skoraj da ni. Kar pa seve- 
da ne pomeni, da kamnita struktura I ni bila uporabljana tudi v kasnejših obdobjih zgodovine.

\section{Povzetek}

Kaštelir nad Kortami pri Izoli je ena od najbolje poznanih prazgodovinskih naselbin v slovenskem delu Istre. Najdišče je prvi omenjal Pietro Coppo v i6. stoletju, na začetku 20. stoletja ga je Carlo Marchesetti označil kot »Il castelliere d'Albuzzano presso Corte d'Isola«, prve sistematične arheološke raziskave pa so na najdišču potekale v sredini 20 . stoletja.

Med 2008 and 2014 je Kaštelir nad Kortami postal glavni poudarek projekta „Kaštelir nad Kortami - Kulturno-rekreacijski part", ki ga je finančno podpirala Občina Izola, izvajal pa Inštitut za dediščino Sredozemlja Univerze na Primorskem.

Vse dosedanje raziskave na Kaštelirju so razkrile izjemen pomen najdišča kot prazgodovinske naselbine. Osrednji prostor platoja je bil naseljen vsaj od poznega neolitika dalje, pa do rimskega obdobja, medtem ko so se v spodnjem delu ohranili naselbinski ostanki iz časa bronaste, železne in rimske dobe. Med prazgodovinskim gradivom prevladuje lončenina. Najdbe, kot so apulijski krater, estenska keramika, figurica bronastega psa, odlomki fibul, jantarna jagoda pa nakazujejo na pomembno vlogo te naselbine zlasti v času razvite železne dobe.

V decembru 2014 je Inštitut za dediščino Sredozemlja Univerze na Primorskem v sodelovanju s Pokrajinskim muzejem Koper izvedel arheološko testno sondiranje, s katerim je pridobili boljši vpogled $\mathrm{v}$ arheološko stratifikacijo plasti na osrednjem platoju gradišča. Ohranjenost plasti naj bi bila na tem delu največja, saj prostor v preteklih desetletjih ni bil povržen intenzivnemu kmetovanju.

Sonda, velikosti 4 x 4 m, je bila locirana ob vznožju kamnite strukture/groblje I na parc. št. I504 k.o. Dvori nad Izolo. Sondiranje je pokazalo, da so se na tem delu najdišča ohranile le ostaline rimskodobne poselitve prostora. Prazgodovinske najdbe so bile izjemno redke in $\mathrm{v}$ sekundarni legi. Sosledje plasti razkriva, da se je nad geološko osnovo odložila rimskodobna plast SE I4, v kateri so bili odkriti odlomki zgodnjerimske namizne keramike s črnim premazom, ki zastopana s sedmimi odlomki. Tovrstna keramika je razprostranjena po celotni obali (npr. Sermin, Fornače, Piran, Pulj, Pomljan, Simonov zaliv idr.) ter je v uporabi od 4. (zahodno Sredozemlje in Italija) do začetka I. stoletja pr. n. št. Nad njo sta se odložili rimskodobni ruševinski plasti SE I6 in SE I3, ki sta si po strukturi in sestavi precej podobni, zaradi česar sklepamo, da sta posledica istega procesa propadanja. $\mathrm{Nad}$ njimi se je formirala kamnita struktura/groblja I, katero prekrivajo še druge ruševinske plasti z rimskodobnimi najdbami, zaradi česar sklepamo, da lahko začetek nastajanja vsaj nekaterih kamnitih struktur na centralnem platoju Kaštelirja postavimo v čas rimske naselitve regije.

Kaštelir nad Kortami je izjemna prazgodovinska naselbinska točka, ampak je pa tudi prostor zgodnje rimske poselitve, ki je zaradi svoje geostrateške lege igrala pomembno vlogo pri zgodnji romanizaciji širšega območja.

\section{Summary}

Kaštelir above Korte near Izola is one of the largest and best known prehistoric settlements in the Slovenian part of Istria. The site was first mentioned by Pietro Coppo in the $16^{\text {th }}$ century. At the beginning of $20^{\text {th }}$ century Carlo Marchesetti described the site as Il castelliere d'Albuzzano presso Corte d'Isola, first systematic archaeological excavation, however took place in mid-20. Century.

Kaštelir has been a main focus of the project "Kaštelir above Korte - Cultural and recreational park", financially supported by the Municipality of Izola and conducted by the Institute for Mediterranean Heritage of University of Primorska between 2008 and 2014.

All previous excavations revealed the particular nature and importance of the site as a prehistoric hillfort. The central plateau has been inhabited at least from late $\mathrm{Ne}$ olithic onwards till the Roman period, while in the lower part settlement remains from Bronze and Iron Age as well as from Roman period have been discovered. Ceramics has been predominant prehistoric finding, while finds such as an imported vessels, the bronze animal representation of dog, amber beads and fibulas indicate the important role of the Kaštelir in Iron Age.

In December 2014 the Institute for Mediterranean Heritage of University of Primorska, in cooperation with Koper regional museum, carried out an archaeological test probing to get the better insight into the archaeological stratification in the central plateau, where 
the archaeological deposits should be preserved at their best, since intensive farming hasn't extended in this area of the site.

The trench ( $4 \times 4 \mathrm{~m}$ ), has been located in the foothill of stone structure I at plot 1504 (Dvori above Izola). The test probing has revealed that in this particular part of the site only remains of Roman period settlement have been preserved. Prehistoric finds have been sporadic and in the secondary position. The stratification of the layers revealed that the first layer above geological base is layer SU I4, containing seven sherds of Early Roman pottery with black slip, which has been found also at other sites in Istria. This kind of pottery has been in use from $4^{\text {th }}$ Century BC in W Mediterranean and Italy till the beginning of $\mathrm{I}^{\mathrm{st}}$ Century $\mathrm{BC}$. Above this layer a couple of rubble debris layers with similar composition, containing Roman finds, have been detected (SUI6 and SE I3), thus concluding that rubble debris layers have been the result of the same process of the decay. Above them the stone structure I has been erected, covered also by several debris layers with Roman findings.

The results of the excavation have underpinned indications of previous studies that the area of Kaštelir above Korte has been intensively used during Roman period. Pottery with black slip and fragments of amphorae of Lamboglia 2 type speak in favour of early Roman settlement, stratification of several layers of debris with exclusively finds from Roman period above the stone structure I foundation however indicate that at least some of the stone structures in the central area of Kaštelir has been erected during Roman period.

Kaštelir above Korte has been considered as prehistoric settlement of exceptional value, but it is also a place of a very early Roman settlement, which has due to its geostrategic location played a very important role in the Romanization of a broader region.

\section{Literatura}

Boltin, Elica. "Arheološke najdbe na Kaštelirju nad Kortami." Arheološki vestnik 9-10/3-4 (1958-59): 237-250.

Boltin, Elica. "Kaštelir nad Kortami." Varstvo spomenikov 7 (1958-59): 279.

Boltin, Elica. "Kaštelir nad Kortami.“ Varstvo spomenikov 7 (1958-59): 293.
Cipriano, Silvia in Francesca Ferrarini. Le amfore romane di Opitergium. Cornuda. Oderzo: Lions club di Oderzo, 200I.

Horvat, Jana in Alma Bavdek. Okra. Vrata med Sredozemljem in Srednjo Evropo. Opera Instituti Archaeologici Sloveniae 17. Ljubljana: ZRC SAZU, 2009.

Marchesetti, Carlo. I castellieri preistorici di Trieste e della regione Giulia. Trieste: Museo civico di Storia naturale, 1903.

Plestenjak, Ana, ur. Sermin, Arheološke raziskave v letu 2010. Ljubljana: Arhej d.o.o, 2012.

Sakara Sučević, Maša. Prazgodovinska keramika med Miljskim zalivom in porečjem Mirne. Koper: Fakulteta za humanistične študije, Univerza na Primorskem (doktorska disertacija neobjavljeno gradivo), 2012.

Sakara Sučević, Maša, Preložnik, Andrej in Aleš Ogorelec. Preliminarno poročilo o zašcitnih arheoloških raziskavah na Kaštelirju nad Kortami, parc. št. I7o6, k.o. Dvori nad Izolo 2.4.-21.4.2010. Koper: Univerza na Primorskem, Znanstvenoraziskovalno središče, Inštitut za dediščino Sredozemlja, 2 оıо.

Tomaž, Alenka in Maša Sakara Sučević. Kaštelir nad Kortami - historična analiza prostora (elaborat). Koper: Inštitut za dediščino Sredozemlja, Znanstvenoraziskovalno središče, Univerza na Primorskem, 2014.

Vidrih Perko, Verena. "Amfore v Sloveniji.“ Annales, Ser. hist. sociol. Io, št. 2 (22)

(2000): 42I-456.
○
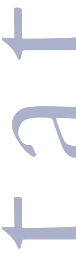

ras
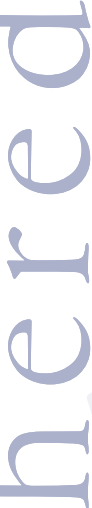


\title{
Implementation of $3 \mathrm{D}$ Scanning in Presentation and Preservation of Cultural Heritage Case Study: Dungeons of the National Museum in Pančevo
}

\author{
Nenad Jončić, ArheoData
}

Zgradba Magistratain zapora predstavlja pomemben del kulturne dediščine mesta Pančevo. Stene celice propadajo zaradi vlage. Zaradi vlage in odpadanja ometa izgubljamo vrezana sporočila zapornikov. Za dokumentiranje trenutne situacije so bili uporabljeni ${ }_{3}$ D skenerji. Poleg visoke natančnosti laserskega skeniranja skener omogoča tudi ustvarjanje visokokakovostnih tekstur na $3 \mathrm{D}$ modelih. Na ta način smo zagotovili varno predstavitev zaporniških celic obiskovalcem muzeja.

Ključne besede: laserski skener, ${ }_{3} \mathrm{D}$ skeniranje, kulturna dediščina, predstavitev, zaščita

\begin{abstract}
The Magistrate building and the dungeons in it represent a significant part of the cultural heritage of the city of Pančevo. Dungeons walls are deteriorating due to moisture and engraved messages of the prisoners are disappearing. $3 \mathrm{D}$ scanners were applied to the record current situation. In addition to the high precision of laser scanning, this scanner also enables the creation of high-quality textures on ${ }_{3} \mathrm{D}$ models. In this way, we provided a safe presentation of dungeons for the visitors of the museum.

Keywords: Laser scanner, 3 D scanning, Cultural heritage, Presentation, Preservation
\end{abstract}

T

he historic buildings are important because they are social and cultural evidence of the past, which is why their reuse needs to be carefully thought out. In their lifetime, many historic buildings, government or not, may lose their function. Some buildings become functionally obsolete, or they are too small due to modern needs. For this reason, many of these historical buildings have been abandoned by the previous users, so their purpose has changed. Reasons why buildings become redundant usually represent changing of economic and industrial practices, demographic changes, increasing the cost of maintenance and primarily because they are no longer suited for the function they were being used. ${ }^{\mathrm{X}}$ Adaptation and re-

I Kağan, Günçe, and Damla Mısırlısoy. "Adaptive reuse of military establishments as museums: conservation vs. museography." WIT Transactions on The Built Environment, (September, 2014): 126, doi: $10.2495 /$ DSHFI $_{1411 \text {. }}$ use of these buildings, through changes of its purpose, and the ways of use, is not a rarity.

Buildings usually change their use through their lifetime; this is a case with the "Magistrate" building in Pančevo that this paper will discuss. The structure was built between 1833 and 1838 , as an administrative building. Throughout the history, this type of buildings was built in order to show the power of the state and to represent its culture and economic wealth. The building has a dominant position in the main city square, with an emphasized main facade. The city administration left the building when a new building was built in 1964 and space changed its purpose and became the National Museum.

The International Council for Monuments and Locations (ICOMOS), define cultural heritage as the expression of lifestyle improved by the community and moved from the past to fu- 
ture generations. ${ }^{2}$ Documentation represents the main ways of protecting, understanding and recognition of the values of the cultural heritage. To achive that goal, heritage monuments need to be well recorded. During the process of documenting cultural monument, it's necessary to capture and record all relevant data and information, everything needs to be saved both in visual and written format ${ }^{3}$. The cultural heritage is worldwide endangered by a different kind of threatening, such as human negligible, weather changes, vandalism, terrorism, population growing and natural disasters. Considering all mentioned, the growing requirement for document and conserve the heritage in the fast and precise way is justified. That is why a process of $3 \mathrm{D}$ documenting, having a great potential, and represent important technique on the international level. Therefore, ${ }_{3} \mathrm{D}$ data is important component for permanent records of the important cultural heritage objects so that they might be saved for future generations. ${ }^{4}$

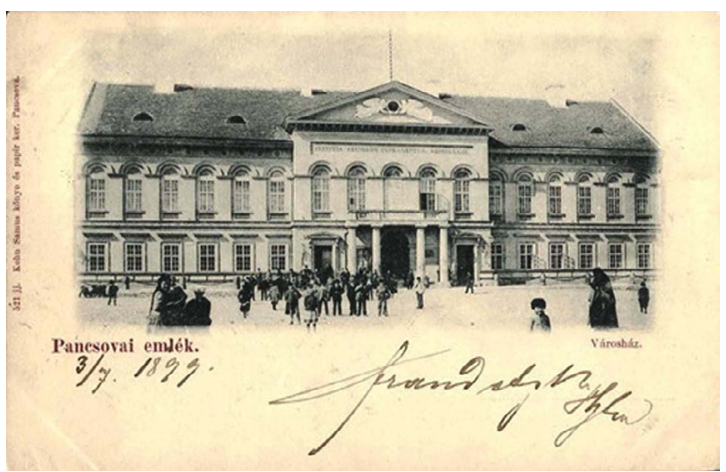

Figure I. The building of the former Magistrate (http:// www.muzejpancevo.rs/pages/o_muzeju/?page $=$ O_ muzeju)

2 Mohsin, M. Shanoer and Fanar M. Abed. "Evaluate 3D laser point clouds registration for cultural heritage documentation" The Egyptian Journal of Remote Sensing and Space Sciences, In Press, Corrected Proof(2017). doi.org/10.1016/j.ejrs.2017.11.007

3 Naif Adel, Haddad. "From ground surveying to 3D laser scanner: A review of techniques used for spatial documentation of historic sites" Journal of King Saud University - Engineering Sciences Vol. 23, Issue 2, (June, 201 I): 109-118. doi.org/10.1016/j.jksues.201 1.03.001

4 Fabio, Remondino and Rizzi Alessandro. "Reality-based $3 \mathrm{D}$ documentation of natural and cultural heritage sites-techniques, problems, and examples" Appl Geomat, Vol. 2, no. 3 (September 2010): 85. doi.org/10.1007/s12518-010-0025-x

\section{The condition}

During the period when the building was an administrative and judicial centre, prison cells were located in the basement of the building. Over the eighty years dungeons have been used, many people were in them, usually during the trial. Preserved inscriptions on the cell walls testify about this (Figure 3). Due to inadequate maintenance of basement, and strong moisture impact, the basement area is in a bad condition. In the basement, conservation works have never been done. The space of the dungeon has never been renovated, and the original messages of the prisoners still stand, like their statements about innocence, fears, hopes, and desires, many of which can still be read on the walls. Graffities originate from various periods and speaks about social and political changes, indicating what happened in this territory over the time (Figure 3). These messages represent a very important part of the cultural heritage of the city, as well as the entire area of South Banat. As the whole cellar is endangered by moisture, there is a real danger that this data will be lost. The wall mortar on which these inscriptions are located is in a very bad condition and the question is whether there is a way to preserve it.

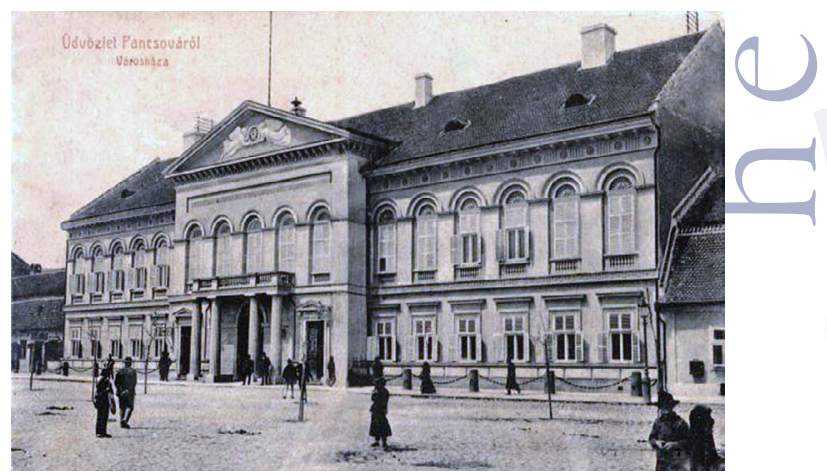

Figure 2. The building of the former Magistrate (http:// www.muzejpancevo.rs/pages/o_muzeju/?page $=$ __ muzeju) 


\section{The idea}

Since this area is in a bad state, it is not possible to organize visits for museum visitors without endangering heritage and people. Therefore, the application of new technologies has been imposed as the best solution. The basic idea, in this case, is the protection and presentation of cultural heritage through digitization and the application of new technologies has been imposed as a solution.

The digitization of cultural heritage is accepted as one of the best and most effective processes for the protection of cultural heritage worldwide. Thanks to the strong and dynamic development of modern technology and science, the process of converting analogue to binary code has been defined as an important way of protecting cultural heritage. Digitalization enables the protection of cultural heritage, eas- ier presentation for the professional and general public. Thanks to modern technology, there is a growing possibility of popularizing cultural heritage through digitization. The main goal is to digitize in order to protect the endangered cultural heritage. One of the specific solutions is to create a ${ }_{3} \mathrm{D}$ model by scanning the endangered space with the latest models of the laser scanner, which in addition to high precision features, brings a high-quality camera too. This procedure will record the current state of the dungeons, and should simultaneously provide a precise three-dimensional model including excellent texture, meaning more precise details on the walls. $3 \mathrm{D}$ laser scanning technology can be used to map the plan of the ceiling, floor, wall surfaces, and masonry facades. This technique can be used to provide evidence of possible structural shifts or deterioration not appar-

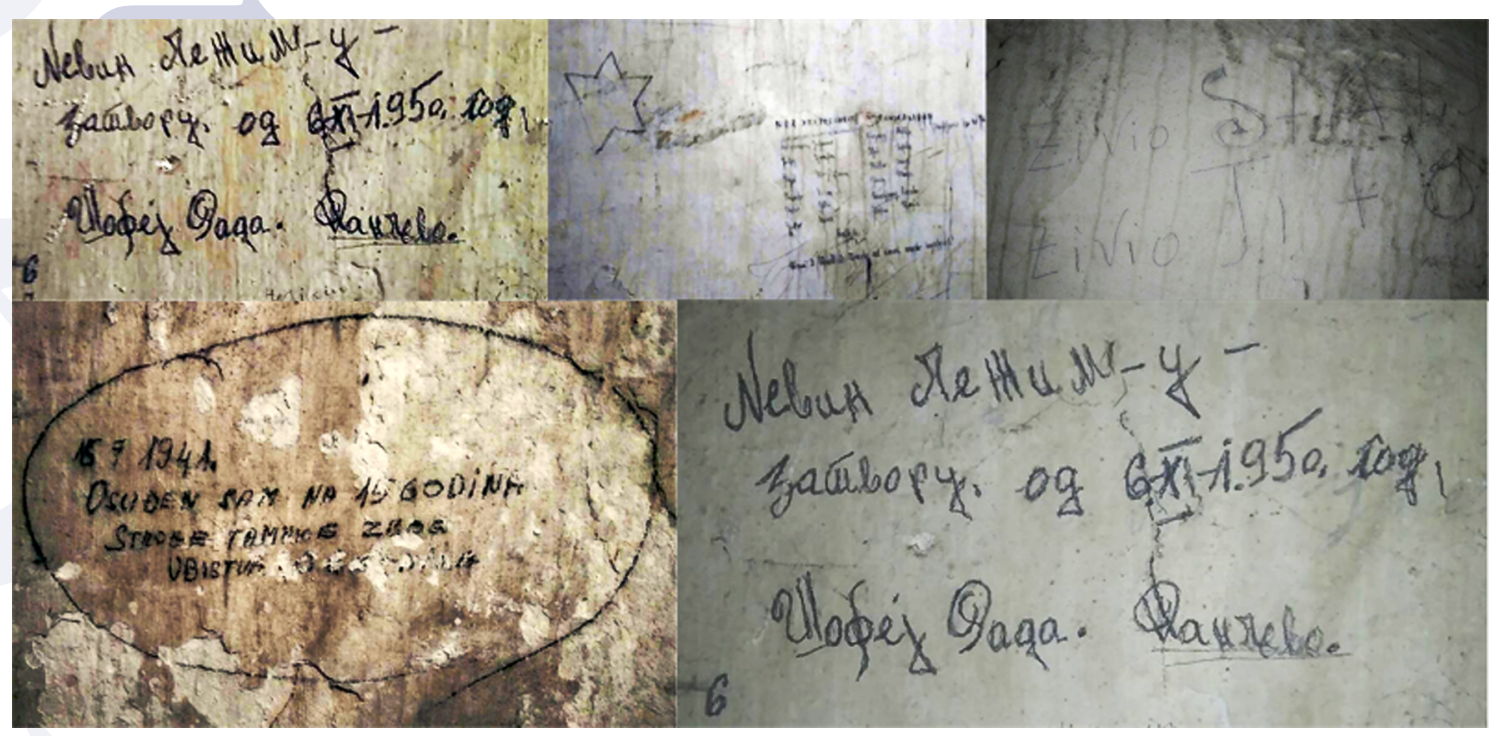

Figure 3. Inscriptions made by prisoners (foto by Nenad Jončić)

ent through traditional visual inspection and measurement methods $s^{5}$. Laser scanning greatly shortens the period of surveying with traditional technical equipment, in relation to work with

John, Smits. "Application of 3 D Terrestrial Laser Scanning to Map Building Surfaces." Journal of Architectural Conservation, 17, no. 1, (November, 2011) 81, doi: 10.1080/13556207.2011.10785083. labour force on the site. In some cases, it is hard to reach every part of the building, wall, ceiling, or the monument when using conventional methods or scaffolds are required. The important question is the extent and how detailed the object or surface will be drawn. The scale of the 
detail and precision of the ${ }_{3} \mathrm{D}$ scans is directly related to the density ratio of the laser beams ${ }^{6}$.

\section{Laser scanning technologies}

Phase-Shift (PS)

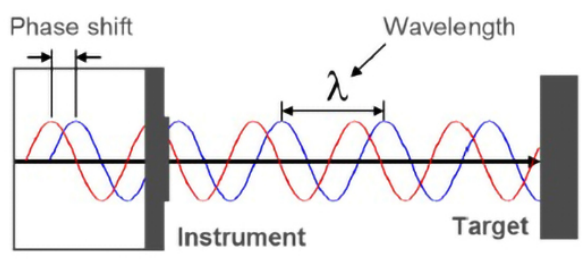

Figure 4. Schematic illustration of the phaseshift

Phase-Shift technology work by sending out a continuous laser beam with a modulated signal embedded in the laser. The scanner compares the phase of the signal at the source with the phase of the laser light once it has travelled to the object and reflected back to the scanner. Recorded changes of phase in laser light are measured and allows the scanner to calculate the distances. ${ }^{7}$ In comparison to Time-of-flight scanners, PS scanners have a lower operational range (8o meters, with some systems reaching up to 120 meters), but can capture more points per second with a higher precision. Generally, PS scanner operates similarly to TOF scanner. The main difference is that PS scanner calculates the time of flight by measuring the difference in the phase of the laser as it returns to the scanner. ${ }^{8}$ Phase-based scan-

6 Benli, Gulhan, and Ozer Derya Gulec. "USE OF LASER SCANNING FOR CULTURAL HERITAGE DOCUMENTATION". International Journal of Electronics, Mechanical and Mechatronics Engineering (IJEMME) 3/1 (June 2013): 447

7 Julia, Armesto-González, Belén Riveiro-Rodríguez, Diego González-Aguilera, and M. Teresa Rivas-Brea. "Terrestrial laser scanning intensity data applied to damage detection for historical." Journal of Archaeological Science 37, no. 12 (December, 2010): 3037-3047, doi: 10.1016/j.jas.2010.06.031.; Alonso J.I., San José, Jose Martínez Rubio, José Fernández Martín Juan, and Jorge García Fernández. "Comparing Time-Of and Phase-Shift the Survey of the Royal Pantheon in the Basilica of San Isidoro (LEÓN)" International Archives of the Photogrammetry, Remote Sensing and Spatial Information Sciences, Volume XXXVIII-5/WI6, (September, 201 I): 377-385, doi: 10.5194/ isprsarchives-KSKSKSVIII-5-VI6-377-2011.

8 Julia, Armesto-González, Belén Riveiro-Rodríguez, Diego González-Aguilera, and M. Teresa Rivas-Brea. "Terrestrial laser scanning intensity data applied to damage detection for historical." ners are typically used in industrial applications such as plants and refineries, or interior architectural spaces.

\section{Time-of-Flight (TOF)}

The time-of-flight method works by sending a laser pulse of light and then measuring the time it takes to travel from the scanner to the object and back, with collected data scanner calculate the distance.' The detector od the scanner will generate a time-tagged trigger pulse depending on set up criteria. Some of the detection methods take characteristic points of the pulse path as the decisive factor ${ }^{\text {Io }}$. Based on the speed of light, we knew the time that laser need to reach the destination and get back to the sensor, thanks to that the location of the object can be determined. A fundamental property of the light wave is its propagation velocity. In a given medium, light waves travel with a constant but finite velocity. The measurement itself is represented by time delays (referred to as the 'time-of-flight') created by light travelling in a medium from the source to the reflective target surface, and back to the source. ${ }^{\text {II }}$ The advantage of this technology is the significant increase the data capturing speed, up to several million points per second. TOF is typically used for exterior civil/survey applications such as topographic surveys of roadways and buildings, since the key benefit of this type of laser scanning technology is its capability of capturing data from a greater distance (from several hundred up to several thousand meters), while maintaining the accuracy in the order of centimetres or smaller units.

Journal of Archaeological Science 37, no. I2 (December, 2010): $3037^{-}$ 3047, doi:10.1016/j.jas.2010.06.031.

9 Julia, Armesto-González, Belén Riveiro-Rodríguez, Diego González-Aguilera, and M. Teresa Rivas-Brea. "Terrestrial laser scanning intensity data applied to damage detection for historical." Journal of Archaeological Science 37, no. I2 (December, 2010): $3037^{-}$ 3047, doi: 10.1016/j.jas.2010.06.031.

Io George, Vosselman and Hans-Gerd Maas. Airborne and Terrestrial Laser Scanning. (Dunbeath: Whittles Publishing, 2010), 5

I I George, Vosselman and Hans-Gerd Maas. Airborne and Terrestrial Laser Scanning. (Dunbeath: Whittles Publishing, 2010), 3

I2 Massimiliano, Pieraccini, Gabriele Guidi and Carlo Atzeni. "3D digitizing of cultural heritage." Journal of Cultural Heritage 2 (I), ( March, 2001): 63-70, doi: 10.1016 / SI296-2074 (oI) or 108-6.; Naci, 
Time of laser pulse is detected

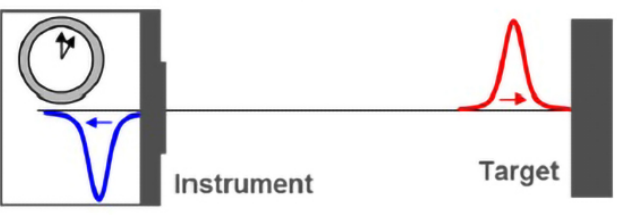

Figure 5. Schematic illustration of the time of flight EDM method

Wave Form Digitizer (WFD)

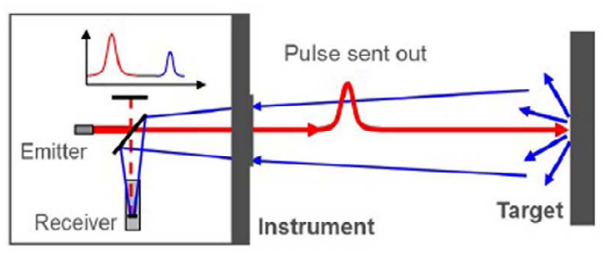

Figure 6. Schematic illustration of the WFD EDM method

The Wave Form Digitizer represents a fast and accurate distance measurements, it is a successful combination of laser scanning and total station in one instrument. ${ }^{13}$ The WFD is a technology system that combines advantages of the phase shift and the time-of-flight method in a unified system. Digitized waveform data have are two basic characteristics, the amplitude quantization, and the time sampling resolution. The amplitude resolution describes the extent of samples that can be used to digitally represent the amplitude of the waveform, expressed in bits. The resolution represents a quantity of how often are the measurements amplitude collected.

Yastikli. "Documentation of cultural heritage using digital photogrammetry and laser scanning." Journal of cultural heritage, 8, Issue 4, (September, 2007): 423-427, doi: 10.1016/j.culher.2007.06.003.; Alonso J.I., San José, Jose Martínez Rubio, José Fernández Martín Juan, and Jorge García Fernández. "Comparing Time-Of and Phase-Shift the Survey of the Royal Pantheon in the Basilica of San Isidoro (LEON)" International Archives of the Photogrammetry, Remote Sensing and Spatial Information Sciences, Volume XXXVIII-5/WI6, (September, 2011): 377-385, doi: 10.5194 / isprsarchives-KSKSKSVIII-5-VI6-377-201 I

I3 Hannes, Maar, and Hans-Martin Zogg. WFD - Wave Form Digitizer Technology, White Paper. Heerbrugg, Switzerland, September 2014.3
With this technology, the distance is calculated on the time between the received start and a stop pulse signals. ${ }^{14}$ Leica BLK 360 scanner is using this technology.

\section{Solution}

Faced by the problems outlined above, we decide to use a laser scanner for documenting, the existing situation in the dungeons. The use of ${ }_{3} \mathrm{D}$ laser scanning in the preservation of cultural heritage is very common nowadays. There have been many studies that illustrate how ${ }_{3} \mathrm{D}$ scanning, implemented in the protection of cultural heritage, produces excellent results, both in terms of speed and precision. $3 \mathrm{D}$ laser scanning is a non-destructive, non-contact method of capturing data that provide accurate and rapid creation of three-dimensional models, for archiving and digital manipulation. $\mathrm{A}_{3} \mathrm{D}$ laser scanner emits a laser beam that hits a target object, measuring millions of closely spaced measurements in a matter of minutes. The scanned measurements are grouped into compressed point cloud databases, which are further generated into a $3 \mathrm{D}$ representation of the object.Is The main task of ${ }_{3} \mathrm{D}$ scanning is to produce models that can be used for presentation and preservation. A technology of $3 \mathrm{D}$ scanning is aimed at collecting information on the shape and texture of the scanned object. The acquired data build a digital three-dimensional mode useful for a wide variety of interpretative and analytical purposes.

The ${ }_{3} \mathrm{D}$ scanner used for scanning dungeons in the building of the National Museum of Pančevo is Leica BLK 360 (Figure 4 ). It turned out that that ${ }_{3} \mathrm{D}$ laser scanning technology has many advantages in this situation. For example, scanning is possible under poor visibili-

I Hannes, Maar and Hans-Martin Zogg. WFD - Wave Form Digitizer Technology, White Paper. Heerbrugg, Switzerland, September 20I4. 4

is Pedro Arias-Sánchez, Herraez Jose, Lorenzo Henrique, and Ordonez Celestino." Control of structural problems in cultural heritage monuments using close-range photogrammetry and computer methods" Computers and Structures, (August 2005): 1754-1766. doi: I0.1016/j.compstruc.2005.02.018; Naci, Yastikli. "Documentation of cultural heritage using digital photogrammetry and laser scanning." Journal of cultural heritage, 8, Issue 4, (September, 2007): 423427, doi: 10.1016/j.culher.2007.06.003 
ty and low illumination gained ${ }_{3} \mathrm{D}$ models can be rotated and measured in the virtual space and can be used for different purpose.

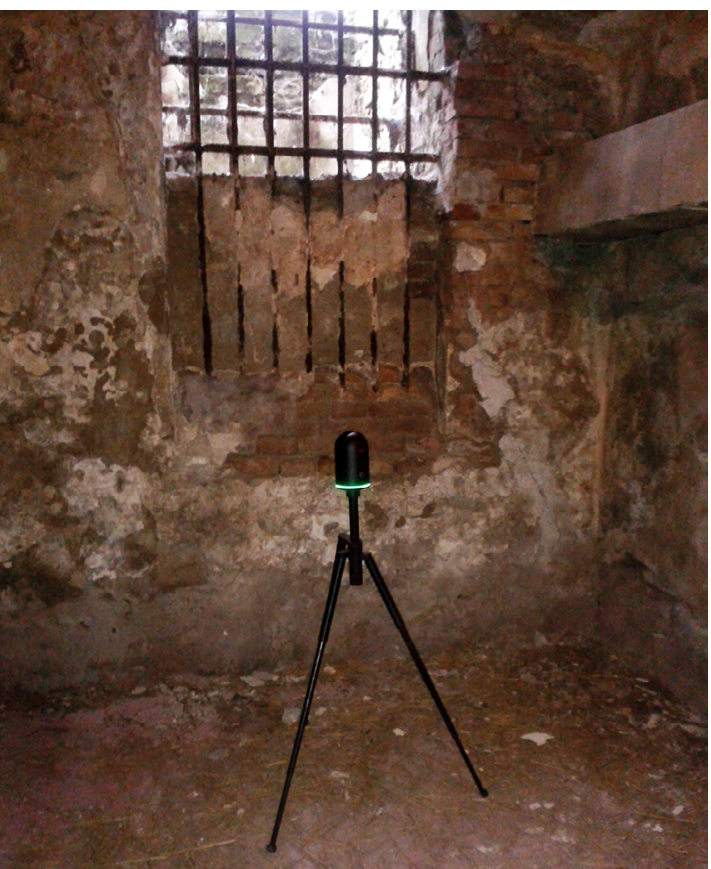

Figure 7. Leica BLK 360 (foto by Nenad Jončić)

The Leica $\mathrm{BLK}_{3} 60$ represent a compact professional ${ }_{3} \mathrm{D}$ scanner, utilizes the high-speed time of light enhanced by Waveform Digitizing technology. Scanner emits an invisible laser beam sent by rotating mirror at a rate of up to 360,000 points per second. The working distance range of the scanner is from $0.6 \mathrm{~m}$ up to $60 \mathrm{~m}$ and the accuracy range of the scanner is from $4 \mathrm{~mm}$ (at $10 \mathrm{~m}$ ) to $7 \mathrm{~mm}$ (at $20 \mathrm{~m}$ ). Leica BLK 360 have three available scanning modes; low, medium and high resolution, with scanning times ranging from approximately 2 minutes for low, and up to 7 minutes in high resolution and full HDR colour.

In most cases, the camera built in the scanner does not provide images with sufficient quality and resolution. Therefore, in order to create correctly colored textures, we have to take photographs with high-quality photographic camera and lens placed in the position that match- es exactly the position of the scanner. But Leica $\mathrm{BLK}_{3} 60$ scanner has three $\mathrm{HDR}$ cameras with Is mp, with LED flashlights, together resulting with full dome capture a $150-\mathrm{mp}$, providing a 360-degree horizontally and 300 degrees vertically coverage. ${ }^{\mathrm{r}} \mathrm{A} \mathrm{BLK}_{3} 60$, has a blind spot directly underneath, that spot is replete with points from the second scan made from another point. Gained 3 D model can aid further analysis, as it provides us with vertical and horizontal cross-sections of the space, as well as precise measurements of the building, which are significant for calculating and reconstruction the architectural plans.

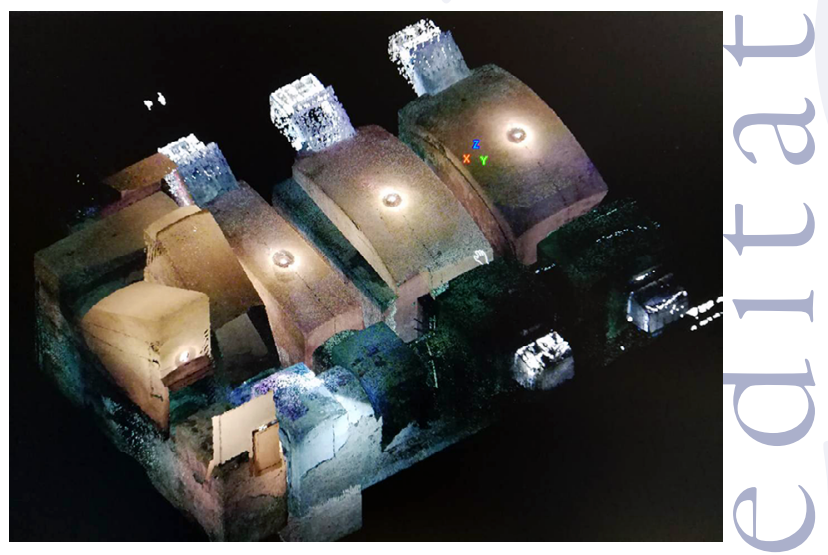

Figure 8.3D model of dungeons (foto by Nenad Jončić)

The $\mathrm{BLK}_{3} 60$ also has a thermal imaging camera placed on the back of the device, that provides a $3 \mathrm{D}$ model with thermal data (Figure 9). ${ }^{17}$ One of the results is a $3 \mathrm{D}$ model with thermal areas that can indicate the level of moisture in the walls (Figure 5), indicating the current state and damage degree of wall mortar. More specifically, it indicates the level of moisture responsible for the degradation of the plaster on which the messages are located. Moisture caus-

I6 Leica Geosystems $A G$. 2018. https://lasers.leica-geosystems.com/ global/sites/lasers.leica-geosystems.com.global/files/leica_me$\mathrm{dia} /$ product_documents/blk/17-lei-030_blk360_spec_sheet_ r2_v2.pdf(accessed june is, 2018)

17 Leica Geosystems AG. 2018. https://asers.leica-geosystems.com/ global/sites/lasers.leica-geosystems.com.global/files/leica_media/product_documents/blk/17-lei-030_blk360_spec_sheet_ r2_v2.pdf(accessed june 15, 2018) 
ing mould, unwanted parasites, and the decanting of salts, and represent one of the main factors in the deterioration of heritage buildings. The existence of moisture is evidence of bad conservation conditions, affects the building aesthetic. Because of all mentioned, it is very important to verify and assess the extent of the moisture, in order to create a moisture protection plan ${ }^{18}$. In other words, it is quite justified fear that prisoners inscriptions will not survive on the walls for a long time, considering that the lower parts of the walls are almost completely free of mortar that was once there.

The Leica $\mathrm{BLK}_{3} 60$ has been developed in close collaboration with Autodesk, the CAD software editor. The ${ }_{3} \mathrm{D}$ scanner is delivered with the Autodesk ReCap 360 Pro Mobile software, compatible with the Apple iPad Pro. The latest version of Autodesk's software registers the $\mathrm{BLK}_{3} 60$ scans in real-time, wherever you are. Autodesk's cloud services enable sharing or easy transfer of data into any Autodesk CAD software for further use.

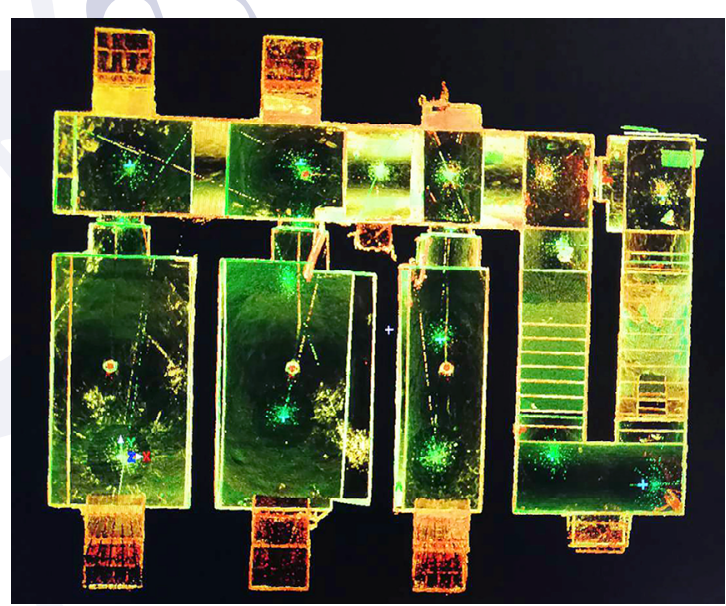

Figure 9. Thermal model of dungeons (foto by Nenad Jončić)

The scanner has built-in, internal memory capacity of ${ }_{32} \mathrm{~GB}$. The $\mathrm{BLK}_{3} 60$ is created for

I8 Pedro Martín, Lerones, Vélez David Olmedo, Rojo Fernando Gayubo, Jaime Gómez-García-Bermejo and Casanova Eduardo Zalama. Moisture detection in heritage buildings by $3 \mathrm{D}$ laser scanning. Studies in Conservation, 61:supi, 46. (April 2016): 46-54. doi: I0.1 179/2047058415Y.0000000017 use both indoors and outdoors, with operating temperature range from +5 to +40 degrees centigrade. ${ }^{19}$ During the scanning of the basement of museum in Pančevo, a temperature was slightly above +5 degrees centigrade, and we experienced some trouble with scanning. From time to time the scanner would stop scanning and show a red light indicator. We solved the problem, by taking the scanner off from the tripod and heating it under our jackets. After the scanner was warmed up, it continued to work normally. That excluded, we needed about 30 minutes to complete the complete scanning of three dungeons cells, guards' rooms, hallway, and stairs.

\section{Conclusion}

The Magistrate building in Pančevo is under the protection as a cultural monument of great importance. The dungeons in the basement, with wall inscriptions representing an important part of the cultural heritage, which is slowly disappearing due to moisture and dereliction.

Implementation of laser $3 \mathrm{D}$ scanning impose like the best solution. During this process was used Leica $\mathrm{BLK}_{3} 60$ scanner, that represents an extremely versatile piece of technology that can be applied to a number of applications and fields across the cultural heritage industry. One of the biggest advantages is a possibility which allows the user to move through a $3 \mathrm{D}$ model using a tablet. This represents a great opportunity for presentation, without fear of damaging the inscriptions or possibility that someone can be hurt during a visit. Obtained ${ }_{3} \mathrm{D}$ models, as well as thermal images, represent a significant fund for professional research.

Through this case study like an example, this paper illustrates how $3 \mathrm{D}$ laser scanning technology can be used for recording the plan of the building, with the aim of protection of cultural heritage. Except for documentation of the current state of the cultural monument, as part of the process of its protection, this technology

\footnotetext{
19 Leica Geosystems AG. 2018. https://lasers.leica-geosystems.com/ global/sites/lasers.leica-geosystems.com.global/files/leica_media/product_documents/blk/17-lei-030_blk360_spec_sheet_ r2_v2.pdf(accessed june 15, 2018)
} 
provides possibilities for the digital presentation of the cultural monument. Furthermore, that involves a lot of possibility for displaying cultural monument that been scanned. Like it is already mentioned results of $3 \mathrm{D}$ scanning can be presented in real time directly on iPad pro. Also, a presentation of a $3 \mathrm{D}$ model of dungeons can be adapted for any touchscreens, the gained ${ }_{3} \mathrm{D}$ model also can be presented with Virtual Reality headsets and allows visitors to walk through the dungeons without any risk for them or cultural heritage.

\section{Povzetek}

Zgradba Magistrata, kot tudi zapora v kleti te stavbe, predstavlja pomemben del kulturne dediščine mesta Pančevo in območja Južnega Banata. Stene zapora se slabšajo zaradi vlage. $\mathrm{Z}$ minerali, ki odpadajo iz obzidja, izgubljamo gravirana sporočila zapornikov. Ta situacija je privedla do zamisli o uporabi $3 \mathrm{D}$ skenerjev v trenutni situaciji. Uporabljen je bil Leica BLK 3653 D skener, ki deluje na principu tehnologije Waveform Digitizer (WFD). Poleg visoke natančnosti laserskega skeniranja ta skener omogoča tudi ustvarjanje visoko kakovostnih tekstur na 3 D modelih. To se doseže z uporabo treh kamer $\mathrm{z}$ visoko ločljivostjo, ki ima vgrajeno tudi optično senzorsko kamero z dolgimi valovi. V tem primeru uporaba toplotne kamere kaže na prisotnost vlage v stenah. Leica $\mathrm{BLK}_{360}{ }_{3} \mathrm{D}$ skener vsebuje programsko opremo Autodesk ReCap 360 Pro Mobile, za Apple iPad Pro. To omogoča enostaven prenos skeniranih podatkov $\mathrm{v}$ katero koli programsko opremo Autodesk CAD za nadaljnjo uporabo. Zagotavlja tudi možnost predstavitve v realnem času ali kasneje, ne glede na lokacijo. Na ta način lahko zagotovimo varno predstavitev za obiskovalce muzeja.

\section{Summary}

The Magistrate building, as well as the dungeons situated in the basement of this building, represents a significant part of the cultural heritage of the city of Pančevo and the area of South Banat. The walls of the dungeons are deteriorating due to moisture. With mortar falling from the walls we are losing engraved messages of the prisoners. This situation led to the idea of applying ${ }_{3} \mathrm{D}$ scanners to the record current situation. The Leica
$\mathrm{BLK}_{36}{ }_{3} \mathrm{D}$ scanner was used, the scanner works on the principle of Wave Form Digitizer (WFD) technology. In addition to the high precision of laser scanning, this scanner also enables the creation of high-quality textures on $3 \mathrm{D}$ models. This is accomplished by using three high-resolution cameras built in, the scanner also has a longwave thermal imaging camera in its encasing. In this case usage of thermal camera, indicate the presence of moisture in the walls. The Leica $\mathrm{BLK}_{3} 60_{3} \mathrm{D}$ scanner is delivered with the Autodesk ReCap 360 Pro Mobile software, for the Apple iPad Pro. This provides easy transfer of scanned data into any Autodesk CAD software for further use. Also providing the possibility for presentation in real-time or later, no matter where you are. In this way, we provide a safe presentation of dungeons for visitors to the museum.

\section{Bibliography}

Arias-Sánchez Pedro, Herraez Jose, Lorenzo Henrique, and Ordonez Celestino.

"Control of structural problems in cultural heritage monuments using closerange photogrammetry and computer methods" Computers and Structures, (August 2005): 1754-1766. doi: 10.1016/j. compstruc.2005.02.018.

Armesto-González, Julia, Belén RiveiroRodríguez, Diego González-Aguilera, and M. Teresa Rivas-Brea. "Terrestrial laser scanning intensity data applied to damage detection for historical." Journal of Archaeological Science 37, no. I2 (December, 2010): 3037-3047, doi: I0.I0I6/j.jas.2010.06.03I.

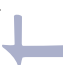

ulhan, Benli, and Ozer Derya Gulec.

"USE OF LASER SCANNING

FOR CULTURAL HERITAGE

DOCUMENTATION". International

Journal of Electronics, Mechanical and

Mechatronics Engineering (IJEMME) 3/I

(June 2013): 447-454

Günçe, Kağan, and Damla Misırlısoy.

«Adaptive reuse of military

establishments as museums: conservation

vs. museography." WIT Transactions on 
The Built Environment, (September, 2014): I25-136, doi: 10.2495/DSHFi 40III.

Leica Geosystems AG. 2018. https://lasers.leicageosystems.com/global/sites/lasers.leicageosystems.com.global/files/leica_media/ product_documents/blk/17-lei-030_ blk360_spec_sheet_r2_v2.pdf (accessed June 15, 2018).

Lerones, Pedro Martín, Vélez David Olmedo, Rojo Fernando Gayubo, Jaime Gómez-García-Bermejo and Casanova Eduardo Zalama. "Moisture detection in heritage buildings by $3 \mathrm{D}$ laser scanning". Studies in Conservation, 6I, no. I, 46-54. (April 2016): 46-54. doi:10.1179/2047058415Y.0000000017.

Maar, Hannes, and Hans-Martin Zogg. WFD - Wave Form Digitizer Technology, White Paper. Heerbrugg, Switzerland, September 2014.

Haddad, Naif Adel. "From ground surveying to $3 \mathrm{D}$ laser scanner: A review of techniques used for spatial documentation of historic sites" Journal of King Saud University - Engineering Sciences Vol. 23, Issue 2, (June, 20II): I09-II8. doi.org/I0.1016/j. jksues.2011.03.001

Pieraccini, Massimiliano, Gabriele Guidi and Carlo Atzeni. "3 $\mathrm{D}$ digitizing of cultural heritage." Journal of Cultural Heritage 2, no. I, (March, 200I): 63-70, doi: 10.1016 / SI296-2074 (OI) oI108-6.

Remondino, Fabio, Rizzi, Alessandro. Realitybased 3 D documentation of natural and cultural heritage sites: techniques, problems, and examples. Applied Geomatics 2 (3), (2010): 85-100, doi.org/10.1007/ SI2518-010-0025-X

San José, Alonso J.I., Jose Martínez Rubio, José Fernández Martín Juan, and Jorge García Fernández. "Comparing TimeOf and Phase-Shift the Survey of the Royal Pantheon in the Basilica of San Isidoro (LEÓN)" International Archives of the Photogrammetry, Remote Sensing and Spatial Information Sciences, Volume
XXXVIII-s/WI6, (September, 20II): 377-385, doi: 10.5194 / isprsarchivesKSKSKSVIII-5-Vi6-377-20II.

Shanoer, Mohsin, M. and Fanar M. Abed. "Evaluate $3 \mathrm{D}$ laser point clouds registration for cultural heritage documentation" The Egyptian Journal of Remote Sensing and Space Sciences, In Press, Corrected Proof (2017). doi.org/10.1016/j.ejrs.2017.11.007

Smits, John. «Application of 3D Terrestrial Laser Scanning to Map Building Surfaces.» Journal of Architectural Conservation, 17, no. 1, (November, 2011) 81 - 94, doi: 10.1080 / I3556207.2011.10785083.

Vosselman, George, and Hans-Gerd Maas. Airborne and Terrestrial Laser Scanning. Dunbeath: Whittles Publishing, 20 Io. Yastikli, Naci. "Documentation of cultural heritage using digital photogrammetry and laser scanning." Journal of cultural heritage, Volume 8, Issue 4, (September, 2007): 423427, doi: 10.1016/j.culher.2007.06.003. 


\section{NAVODILA ZA AVTORJE}

Revija objavlja primarno v slovenskem jeziku, toda tudi v večjih svetovnih jezikih (angleščina, nemščina, francoščina, italijanščina, ruščina). V objavo se sprejmejo tudi članki v cirilici. V primeru tujejezičnega članka morata biti izvleček in povzetek poleg angleščine obvezno v slovenskem jeziku. Za oboje poskrbi avtor.

Članek (praviloma v obsegu 7000 , vendar največ 10.000 besed) naj ima na začetku: 1) naslov ter ime in priimek avtorja/-ice; 2) izvleček v slovenskem in abstract angleškem jeziku, do 250 besed; 3 ) ključne besede v slovenščini in angleščini (do 5); 4) kratko predstavitev avtorja/-ice (do roo besed v slovenščini in angleščini), navedena naj bo tudi organizacija zaposlitve. Članek naj po razpravnem besedilu vsebuje še: I) povzetek v slovenščini in angleščini ter 2) seznam virov in literature.

Prispevki naj bodo napisani v knjižni slovenščini (ali v knjižni različ̌ici katerega tujih jezikov, v kolikor gre za tujejezično delo) ob upoštevanju veljavnega pravopisa, v nasprotnem primeru si uredništvo pridržuje pravico, da članka ne recenzira oziroma ga zavrne.

Če je prispevek že bil objavljen v kaki drugi reviji ali če čaka na objavo, je treba to izrecno navesti.

Prispevek naj ima dvojni medvrstični razmik, tip črk naj bo Times New Roman, velikost 12 pik (v opombah 10). Besedilo naj bo levo poravnano, strani pa zaporedno oštevilčene. Odstavki naj bodo ločeni s prazno vistico.

Uporabiti je mogoče do tri hierarhične nivoje podnaslovov, ki naj bodo ośtevilčeni (uporabljajte izključno navaden $s l o g$, v prelomu bodo ravni ločene tipografsko): I. - I.I - I.I.I

Za poudarke uporabite izključno ležeći tisk(v primeru jezikoslovnih besedil, kjer so primeri pravilomavležečem tisku, lahkoza poudarke izjemoma uporabite polkrepki tisk). Ležeče pišite tudi besede v tujih jezikih. Raba drugih tipografskih rezov (podčrtano, velike male črke, krepko kurzivno ...) ni dovoljena. Ne uporabljajte dvojnih presledkov, prav tako ne uporabljajte preslednice za poravnavo besedila. Edina oblika odstavka, ki je dovoljena, je odstavek z levo poravnavo brez rabe tabulatorjev prve ali katerekoli druge vrstice v ostavku (ne uporabljajte sredinske, obojestranske ali desne poravnave odstavkov). Oglate oklepaje uporabljajte izključno za fonetične zapise oz. zapise izgovarjave. Tri pike so stične le, če označujejo prekinjeno bese... Pri nedokončani misli so tri pike nestične in nedeljive ... Prosimo, da izključite funkcijo deljenja besed.

Sprotne opombe naj bodo samooštevilčene (številke so levostično za besedo ali ločilom - če besedi, na katero se opomba nanaša, sledi ločilo) in uvrščene na tekočo stran besedila.

Citati v besedilu naj bodo označeni z dvojnimi (» «), citati znotraj citatov pa z enojnimi (") narekovaji. Izpuste iz citatov in prilagoditve označite s tropičjem znotraj poševnic /.../. Daljše citate (več kot s vrstic) izločite v samostojne odstavke, ki jih od ostalega besedila ločite $\mathrm{z}$ izpustom vrstice in umikom $\mathrm{v}$ desno. Vir citata označite $\mathrm{v}$ okroglem oklepaju na koncu citata. Če je avtor/-ica naveden/-a v sobesedilu, priimek lahko izpustite.
V besedilu označite najprimernejša mesta za likouno opremo (tabele, slike, skice, grafikone itd.) po zgledu: [Tabela I približno tukaj]. Posamezne enote opreme priložite vsako v posebni datoteki (v.eps, ai, .tif ali .jpg formatu, minimalna resolucija $300 \mathrm{dpi}$, tabele prilagajte v posebni datotetki v formatu .doc, grafe pa v formatu .xls, kjer naj ob grafu stoji tabela, ki je podlaga za graf). Naslov tabele je nad tabelo, naslov grafa/slike pa pod grafom/sliko.

Prostor, ki ga oprema v prispevku zasede, se šteje v obseg besedila, bodisi kot 250 besed (pol strani) ali 500 besed (cela stran).

Ob oddaji preda avtor uredništvu članek v formatu .doc in hkrati tudi.pdf.

Za citiranje literature in za pripravo seznama uporabljene literature se uporablja izkljucno stil Chicago, in sicer v obliki, kot je aktualna, tj. v svoji i6. izdaji (http://www.chicagomanualofstyle.org/home.html, 16. izdaja na razpolago na zahtevo tudi pri uredniku izdaje)

I: Enoavtorska monografija

a) Polna oblika reference pod crrto: Michael Pollan, The Omnivore's Dilemma: A Natural History of Four Meals (New York: Penguin, 2006), 99-100.

b) Kratka oblika reference pod črto: Pollan, Omnivore’s Dilemma, 3 .

c) Navedba v virih in literaturi: Pollan, Michael. The Omnivore's

Dilemma: A Natural History of Four Meals. New York: Penguin, 2006. II: Većavtorska monografija

a) Polna oblika reference pod črto: Geoffrey C. Ward and Ken Burns, The War: An Intimate History, 1941-1945 (New York: Knopf, 2007), 52

b) Navedba v virih in literaturi: Ward, Geoffrey C., and Ken Burns. The War: An Intimate History, 1941-1945. New York: Knopf, 2007.

III: Knjiga z urednikom

a) Polna oblika reference pod črto: Joel Greenberg, ed., Of Prairie, Woods, and Water: Two Centuries of Chicago Nature Writing (Chicago: University of Chicago Press, 2008), 42.

b) Kratka oblika reference pod črto: Greenberg, Prairie, Woods, and Water, 326-27.

c) Navedba v virih in literature: Greenberg, Joel, ed. Of Prairie, Woods, and Water: Two Centuries of Chicago Nature Writing. Chicago: University of Chicago Press, 2008.

IV: Poglavje v knjigi

a) Polna oblika reference pod črto: Glenn Gould, "Streisand as Schwarzkopf," in The Glenn Gould Reader, ur. Tim Page (New York: Vintage, 1984),310.

b) Kratka oblika reference pod črto: Gould, "Streisand as Schwarzkopf," 309 .

c) Navedba v virih in literaturi: Gould, Glenn. "Streisand as Schwarzkopf." In The Glenn Gould Reader, ur. Tim Page, 308-11. New York: Vintage, 1984 .

Gould, "Streisand as Schwarzkopf," 309 
V: Clanek v reviji

a) Polna oblika reference pod črto: Walter Blair, "Americanized Comic Braggarts," Critical Inquiry 4, no. 2 (1977):331-32.

b) Kratka oblika reference pod črto: Blair, "Americanized Comic Braggarts," 335 .

c) Navedba v virih in literaturi: Blair, Walter. "Americanized Comic Braggarts." Critical Inquiry 4, no. 2 (1977): 331-49.

VI: Clanek v reviji (digitalna objava; DOI)

a) Polna oblika reference pod črto: William J. Novak, "The Myth of the 'Weak' American State," American Historical Review Ir3 (June 2008): 758, doi:10.1086/ahr.113.3.752.

b) Kratka oblika reference pod črto: Novak, "Myth," 770 .

c) Navedba v virih in literaturi: Novak, William J. "The Myth of the 'Weak' American State." American Historical Review 113 (June 2008): 752--72. doi:10.1086/ahr.113.3.752., "Streisand as Schwarzkopf," 309.

VII: Članek v reviji (digitalna objava, URL)

a) Polna oblika reference pod črto: Wilfried Karmaus and John F. Riebow, "Storage of Serum in Plastic and Glass Containers May Alter the Serum Concentration of Polychlorinated Biphenyls," Environmental Health Perspectives II2 (May 2004): 645, http://www. jstor.org/stable/3435987 (datum dostopa do spletne strani).

b) Navedba v virih in literaturi: Karmaus, Wilfried, and John F. Riebow. "Storage of Serum in Plastic and Glass Containers May Alter the Serum Concentration of Polychlorinated Biphenyls." Environmental Health Perspectives II2 (May 2004): 643--47. http:// www.jstor.org/stable/3435987.

O morebitnih drugih posebnostih se posvetujte z uredništvom

Naslov uredništva: dr. Gregor Pobežin, Fakulteta za humanistične študije Univerze na Primorskem, Titov trg 5,

SI-6000 Koper, gregor.pobezin@fhs.upr.si 

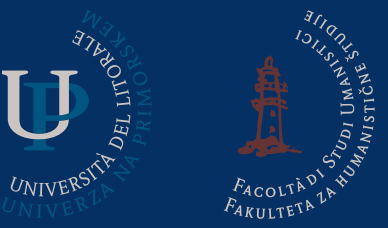

Založba Univerze na Primorskem www.hippocampus.si ISSN 2350-5443

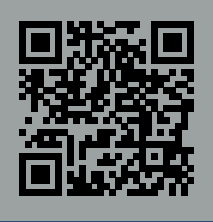

